\title{
Anaerobic calcium phosphate bio granulation
}

Jorge Ricardo Cunha 


\section{Thesis committee}

\section{Promotors}

Prof. Dr Cees J. N. Buisman

Professor of Biological Recovery and Reuse Technology

Wageningen University \& Research

Prof. Dr Grietje Zeeman

Personal chair at the Sub-department of Environmental Technology

Wageningen University \& Research

\section{Co-promotor}

Dr Renata D. van der Weijden

Senior Researcher, Sub-department of Environmental Technology

Wageningen University \& Research

\section{Other members}

Prof. Dr Merle K. de Kreuk, Delft University of Technology

Prof. Dr M. Madalena Alves, University of Minho, Portugal

Prof. Dr Sjoerd E. A. T. M. van der Zee, Wageningen University \& Research

Dr Marthe S. de Graaff, Evides Industriewater, Rotterdam

This research was conducted under the auspices of the Graduate School for Socio-Economic and Natural Sciences of the Environment (SENSE) 


\title{
Anaerobic calcium phosphate bio granulation
}

\author{
Jorge Ricardo Cunha
}

\section{Thesis}

submitted in fulfillment of the requirements for the degree of doctor

at Wageningen University

by the authority of the Rector Magnificus,

Prof. Dr A.P.J. Mol,

in the presence of the

Thesis Committee appointed by the Academic Board

to be defended in public

on Friday 30 November 2018

at 4 p.m. in the Kanselarij, Leeuwarden. 
Jorge Ricardo Cunha

Anaerobic calcium phosphate bio granulation,

214 pages.

PhD thesis, Wageningen University, Wageningen, the Netherlands (2018)

With references, with summary in English

ISBN 978-94-6343-503-1

DOI https://doi.org/10.18174/457977 


\section{Table of Contents}

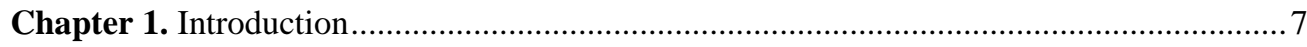

Chapter 2. Simultaneous recovery of calcium phosphate granules and methane in anaerobic treatment of black water: effect of bicarbonate and calcium fluctuations .23

Chapter 3. Calcium addition to increase the production of phosphate granules in anaerobic treatment of black water. 39

Chapter 4. The effect of bio-induced increased $\mathrm{pH}$ on the enrichment of calcium phosphate in granules during anaerobic treatment of black water 63

Chapter 5. Bulk pH and carbon source are key factors for calcium phosphate bio granulation

Chapter 6. Recovery of calcium phosphate granules from black water using a hybrid Upflow Anaerobic Sludge Blanket - Gas-Lift (UASB-GL) reactor .99

Chapter 7. Characterization of recovered calcium phosphate granules from black water .. 121

Chapter 8. General discussion and outlook 141

Summary 161

References 163

Appendices 180

Acknowledgements. 208

About the author 211 

Chapter 1. Introduction 


\subsection{The powerful nutrient phosphorus}

The discovery of phosphorus by the alchemist Henning Brandt in the year of 1669 led to death and massive destruction, but doctors still recommended phosphorus as a food additive (Ashley et al., 2011; Emsley, 2000). The experiment of Henning Brandt explains this controversy. He used aged human urine to unintentionally produce self-luminous white phosphorus, which is the most reactive form of phosphorus and one of the compounds used to produce explosives (Emsley, 2000). Brandt's experiment worked because phosphorus is present in considerable amounts in urine, indicating that food contains phosphorus (Elser and Bennett, 2011). Moreover, during the $19^{\text {th }}$ and first half of the $20^{\text {th }}$ centuries, bones were a major source of white phosphorus for military applications, supporting the important role of phosphorus in living organisms (Ashley et al., 2011).

From microorganisms to humans, phosphorus is a constituent of important molecules and composites. For instance, adenosine triphosphate (ATP), which is the primary carrier for intracellular energy transfer in all life forms, contains three atoms of phosphorus (Kornberg et al., 1999). Although phosphorus is an essential element, humans only metabolize $5 \%$ of the phosphorus eaten; the rest is excreted via urine ( 60\%) and feces ( 40\%) (Wyant et al., 2013). The filtration of blood in the kidneys results in urine production, which functions as storage of waste material from the bloodstream, such as urea and excess of nutrients, including phosphorus (Lawrence et al., 2018). Phosphorus in human urine is mostly in the soluble form $\left(\mathrm{H}_{2} \mathrm{PO}_{4}{ }^{3-} / \mathrm{HPO}_{4}{ }^{3-}\right.$ at $\mathrm{pH} 6$ to 7$)$ and it fluctuates between 0.4 and $1 \mathrm{~g}$ per litter ( 0.6 to $1 \mathrm{~g}$ person${ }^{1}$ day $^{-1}$ ), depending on dietary habits and where people live (Randall and Naidoo, 2018). Feces are composed of bacterial biomass, undigested food residues, macromolecules (e.g., fibers, proteins, and DNA), and other small molecules (Karu et al., 2018). In feces, phosphorus is mostly in the solid form, representing $5 \mathrm{~g} \mathrm{~kg}^{-1}$ of feces $\left(0.3\right.$ to $0.7 \mathrm{~g}$ person $^{-1}$ day $^{-1}$ ) (KujawaRoeleveld and Zeeman, 2006).

Although humans excrete on average $95 \%$ of the phosphorus consumed, the same does not happen for plants (Wyant et al., 2013). Plants require phosphorus for all the growth and reproductive stages, and phosphorus represents $0.2 \%$ of the plant weight (McGrath et al., 2014). Moreover, plants assimilate atmospheric $\mathrm{CO}_{2}$ and sunlight to produce organic carbon and $\mathrm{O}_{2}$. Thus, plants are the primary producers in the food chain and the main source of atmospheric $\mathrm{O}_{2}$, which means that we are dependent on plants for breathing and food production, and in turn, plants are dependent on phosphorus for growth. Besides being an important element in our body, phosphorus also plays a vital role in food production. 
The natural source of phosphorus, mainly phosphate rock, has limited availability for plants (Emsley, 2000; Schröder et al., 2011). Plants can mostly take up phosphorus from the soil solution as $\mathrm{H}_{2} \mathrm{PO}_{4}{ }^{3-}$ and $\mathrm{HPO}_{4}{ }^{3-}$, which results from dissolution and desorption from mineral surfaces and clay, respectively, and decomposition of organically bound phosphorus (McGrath et al., 2014; Sato et al., 2009). The speciation of phosphorus in the soil solution is dependent on $\mathrm{pH}$ : for $\mathrm{pH}<6$ phosphorus binds strongly to $\mathrm{Fe}$ and $\mathrm{Al}$, while for $\mathrm{pH}>7$ phosphorus binds $\mathrm{Ca}$ and $\mathrm{Mg}$ (McGrath et al., 2014). In both situations, the bioavailability of phosphorus decreases. Thus, plants utilize all phosphorus they extract from the soil, indicating that phosphorus availability is of primary importance for global food security (Schröder et al., 2011).

Until the $18^{\text {th }}$ century, the close distance between population and agriculture enabled the almost complete recycling of phosphorus from human excreta (known as "night soil"), animal manure, and organic waste in agricultural soil. However, in the $19^{\text {th }}$ century, the increasing world population and the foundation of cities led to the disruption of the phosphorus cycle (Ashley et al., 2011). The increase in population density and the need for hygiene in the cities led to the development of sanitation systems, which conveniently discharged the wasted phosphorus into rivers instead of returning it to agricultural land. The increasing need for nutrients in the $20^{\text {th }}$ century, lead to the Green Revolution, which changed the agricultural landscape in industrialized countries drastically (Driver et al., 1999). The basis for the Green Revolution was the Harber's invention for synthesis of ammonia $\left(\mathrm{NH}_{3}\right)$, stimulating the production of nitrogen fertilizers (Smil, 2002). Consequently, the urge for finding alternative sources of phosphorus started, due to the increasing fertilizer demand initiated by the ammonia production. The rapid exploitation of mineral phosphorus, mainly phosphate rock from the USA and North Africa, and the production of artificial fertilizers raised crop yields significantly, which were necessary to keep up with demanding dietary habits (Ashley et al., 2011). World population increased from 2.5 billion in 1951 to 6.1 billion in 2000, and to 7.5 billion in 2017 (Roser and Ortiz-Ospina, 2018).

The excessive and linear use of phosphorus from phosphate rock in the last century resulted in eutrophication of natural surface water, due to the runoff of phosphorus from agricultural land and urban areas (Jarvie et al., 2006; Schröder et al., 2011). The global annual extraction of phosphate rock increased from 1.5 million tons of phosphorus in 1940 to 18 million tons of phosphorus in 2010 (Ashley et al., 2011). Additionally, the application of artificial fertilizer, which is composed of phosphorus, potassium, and nitrogen, in agriculture leads to the continuous extraction of carbon from soil, resulting in soil degradation. The 
degradation of soil reduces the capacity for retention of nutrients in intensive agricultural areas, promoting the runoff of phosphorus (Alexander et al., 2015; Schröder et al., 2011; Squire et al., 2015). Thus, soil degradation and over-application of nutrients are the major cause of surface water pollution. However, now, in the $21^{\text {st }}$ century, the peak for the phosphate rock available on earth was announced, indicating that phosphorus eventually will no longer be available by extraction from nature (Koppelaar and Weikard, 2013), apart from possible geopolitical and geographical constraints that can occur due to phosphorus scarcity. From a known aquatic pollutant, phosphorus can become a scarce nutrient for agriculture without a known substitute.

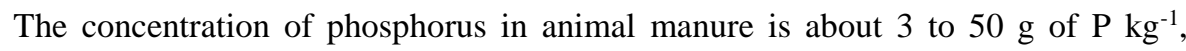
depending on the animal type, diet, and dilution at collection (He et al., 2016). Phosphorus in animal manure is recycled on land, but the intensive livestock exploitation causes geographic surpluses of phosphorus (Liu et al., 2008; Smit et al., 2010a). For instance, the phosphorus surplus in the Netherlands $\left(+16 \mathrm{kgP} \mathrm{ha}^{-1}\right.$ of agricultural land, considering the annual inflow and outflow of phosphorus) resulted in stricter regulation for application of manure on agricultural land, forcing manure producing farmers to transport manure to UK and Germany (Smit et al., 2010a). At this moment a market for phosphate rights is established in the Netherlands. The intensification and geographic concentration of livestock farms and application of raw manure on land cause over-application of phosphorus, regarding the actual required amount for crop production (Schröder et al., 2011). Therefore, there is an urgent need to recover phosphorus from both animal manure and human excreta in a manner that allows the transport of phosphorus from agricultural areas with a surplus to areas with a shortfall of phosphorus.

Since 2000, many researchers have developed innovative technologies for recovery of phosphorus from wastewater (Desmidt et al., 2015; Lebuf et al., 2013). However, the regulatory limits of hazardous substances for application as fertilizer, such as heavy metals, micropollutants, and pathogens, and economic drawbacks limit the implementation of these technologies (Desmidt et al., 2015). Recently, the regulation for application of fertilizing products has been revised, including specifications for the application of products from waste (European Commission, 2016). Thus, the revised regulation stimulates the development and implementation of technologies for recovery of nutrients (nitrogen, potassium, and phosphorus) and, perhaps at the same level of importance, recovery of organic matter. The efficient recycling of wasted phosphorus on land can potentially close the phosphorus cycle, preventing the dependency on mineral phosphorus from phosphate rock. 


\subsection{Past, present and new sanitation}

Until 10000 years ago, nutrients and organic matter in manure, human excreta, and

crop residues were entirely recycled on land because communities were relatively small and nomadic (Ashley et al., 2011). The ecological problems of waste disposal started with the establishment of permanent settlements. Regarding the western history of sanitation, there are three distinct periods of evolution: the ancient times and pre and post-Industrial Revolution. During the ancient times, until the year of 476, Egyptians, Greeks, and Romans developed rudimentary technologies for collection, transport, and even treatment of wastewater (Lofrano and Brown, 2010). Wastewater was generally used in agricultural land near the urban area (Ashley et al., 2011; Lofrano and Brown, 2010). However, the knowledge developed during ancient times vanished with the collapse of the Roman empire, starting the middle age and the dark period of sanitation and public health (Lofrano and Brown, 2010).

Urban areas grew significantly in the middle ages, and the early Industrial Revolution at the end of the $18^{\text {th }}$ century further boosted the development of urban centers (Ashley et al., 2011; Bosker and Buringh, 2017). From 34 cities larger than 5000 people equivalent (p.e.) in Europe in the year 800, the number increased to 1450 cities in 1800 (Bosker and Buringh, 2017). At the same time, the intense production of wastewater in cities, which was stored mostly in cesspits or discharged untreated in the near river, led to contamination of drinking water reservoirs. Between the $5^{\text {th }}$ and $18^{\text {th }}$ century, a third to half of the European population was killed by plagues, which were caused by the lack of sanitation systems and consequent contamination of drinking water, due to infiltration of wastewater (Drancourt and Raoult, 2016; Lofrano and Brown, 2010). During the $19^{\text {th }}$ century, the intense industrialization and production of wastewater in cities forced the implementation of sewer systems, but the impact of untreated wastewater discharge in the surface water soon became a serious threat to the public health (Lofrano and Brown, 2010).

The post-Industrial Revolution era, in the early $20^{\text {th }}$ century, marked a change in wastewater disposal. The Royal Commission on sewage disposal (1915) from Great Britain elaborated the Eighth Report in 1912, presenting for the first time the concept of biochemical oxygen demand (BOD) and the analytical standardization of influents and effluents. Afterward, other countries adopted the guidelines in the Eighth Report, and wastewater treatment became a must (Lofrano and Brown, 2010). Wastewater treatment evolved significantly in the $20^{\text {th }}$ century, but a crucial factor was the parallel development and spread of analytical Standard Methods since 1900, which helped to determine the actual treatment 
efficiency, stimulating further the technological progress (Clesceri et al., 1998; Tsuzuki, 2014). The history, principles, and technology for wastewater treatment during the $20^{\text {th }}$ century are very well documented, including the need for phosphorus removal from wastewater before discharge, besides organic matter and nitrogen (Tchobanoglous et al., 2004). The fast implementation of wastewater treatment in cities, combined with the intention of removing wastewater from the urban area, promoted the development of long sewer systems and centralized treatment of domestic, industrial, and urban wastewater (Lofrano and Brown, 2010). The removal of pollutants from wastewater during the $20^{\text {th }}$ century was meant to improve public health and pollution, but by the end of the $20^{\text {th }}$ and beginning of the $21^{\text {st }}$ centuries, the focus also included environmental protection and recovery and reuse of water, nutrients, and energy from waste (Rydin et al., 2012). The implementation of biological processes for wastewater treatment resulted in sludge production (Kelessidis and Stasinakis, 2012). The European Directive 86/278/EEC from 1986 encouraged the application of produced sludge in agriculture. However, the increasing production and presence of toxic compounds in sewage sludge (heavy metals, micropollutants, and pathogens) triggered the implementation of more restrict regulatory limits by 2000, and other disposal options for sewage sludge, such as incineration and landfill, were adopted, reducing the recycling of organic matter and nutrients (Kacprzak et al., 2017; Kelessidis and Stasinakis, 2012).

The evolution in wastewater treatment was prosperous for industrialized countries in the last century, but for developing countries, the infrastructure for sanitation (i.e., wastewater collection, transport, and treatment) is often similar to as it was in the middle ages in European countries (Daigger et al., 2007; Lofrano and Brown, 2010). Therefore, the lessons learned should facilitate and encourage good practices in developing countries, considering the additional focus on recovery of resources from wastewater.

The centralized collection and treatment of wastewater focused mainly on public health, but currently also concerns with climate change, water pollution, and nutrient constraints and scarcity call for more sustainable treatment schemes (Lens et al., 2001). Centralized systems can handle domestic, industrial, and street-runoff wastewater, but the aging of infrastructure and capacity limitations require reconstruction and expansion of the sewers and treatment plants, respectively. Moreover, the implemented treatment systems (e.g., activated sludge with aeration, nitrification and denitrification, and biological phosphorus removal) enable the removal of pollutants, such as organic matter, nitrogen, and phosphorus. However, these are also essential resources for agriculture (Lofrano and Brown, 2010). For instance, the Dutch water authorities have transformed the purpose of wastewater treatment 
from removal of pollutants to recovery of valuable resources, such as renewable energy, raw materials, and clean water (Dutch Water Boards, 2015).

New sanitation principles, which are based on a separate collection of water from the bath, sink, and laundry (gray water) and toilet water (black water) potentially together with organic kitchen waste, enables the recovery of the included resources, such as nutrients (nitrogen, phosphorus, and potassium), energy, and water, instead of only removal of pollutants (Zeeman, 2012). Additionally, new sanitation incentives decentralized treatment for maximizing the local reuse of resources. Regarding black water, the vacuum collection increases the concentration of organic matter and nutrients by decreasing the volume of water used for flushing the toilet, from 6 to $12 \mathrm{~L}$ per flush in regular toilets to 0.8 to $1 \mathrm{~L}$ per flush with vacuum collection (Kujawa-Roeleveld and Zeeman, 2006). The lower dilution and consequent higher concentration of nutrients and organic matter allow the implementation of recovery technologies with high output capacity, considering the input volume when compared with the conventional mixed collection and centralized treatment.

\subsection{Resource recovery from anaerobic treatment of black water}

Food is the source of energy and nutrients (nitrogen, phosphorus, and potassium) for humans, but the metabolic efficiency for uptake of carbon and nutrients is relatively low compared to plants (Wyant et al., 2013). Regarding phosphorus, the assimilation by the human body is very low, and phosphorus ends up almost entirely in excreta as solid and soluble $\left(\mathrm{PO}_{4}{ }^{3-}\right.$ ) phosphorus (Wyant et al., 2013). Nitrogen, which was the limiting nutrient for food production before the synthesis of ammonia from atmospheric nitrogen $\left(\mathrm{N}_{2}\right)$, is almost completely metabolized and assimilated by humans (Smil, 2002). Because the Harber-Bosch process is energetically demanding but still crucial for food production, the recovery of liquid nitrogen (reactive) from waste streams is very attractive (Kuntke et al., 2018). Potassium, which is another essential macronutrient for humankind and responsible for blood pressure stabilization, is currently undervalued (He and MacGregor, 2008). Food processing and coking have reduced the consumption of potassium by humans significantly (He and MacGregor, 2008). The rising consumption of salt and lower consumption of potassium are known to increase blood pressure, leading to health problems. The main sources of potassium for agriculture are mineral potash $\left(\mathrm{K}_{2} \mathrm{O}\right)$ and potassium-bearing rock and clay deposits, with limited availability (Meena et al., 2016). Therefore, the recovery of energy and nutrients from black water (feces and urine) is crucial for their sustainable use and circular economy. In this thesis, we use anaerobic digestion to convert the organic carbon in black water into methane 
gas for energy production and the phosphorus into calcium phosphate, which has similar elemental composition as phosphate rock.

The organic load in black water consists of a diversity of solid, colloidal, and soluble organic compounds. Thus, a diverse consortium of microorganisms is necessary to go from solid to gaseous carbon (Tchobanoglous et al., 2004). Anaerobic digestion of particulate organic matter involves four main metabolic steps: (1) hydrolysis of solids, (2) fermentation/acidogenesis, (3) acetogenesis, and (4) methanogenesis (Lier et al., 2008). These four steps are well known and described in the literature, as well as the requirements for efficient conversion of organic carbon into methane (Antwi et al., 2017; Batstone, 2000; Batstone et al., 2002a; Mahmoud et al., 2003; Tchobanoglous et al., 2004).

The concept of anaerobic treatment by upflow of the wastewater through a sludge bed, containing a mixed microbial community, was introduced by Lettinga et al. (1980). The upflow anaerobic sludge blanket (UASB) reactor enables the decoupling of the solid (biomass and particulate organic matter) retention time from the hydraulic retention time, meaning that it can handle a relatively high organic loading rate, requiring a relatively low reactor volume. The biomass retained in the UASB reactor generally has high settling velocity, reducing the flow of solids with the wastewater, and consequently, increasing the effluent quality (Liu et al., 2006). The performance of the UASB concept for black water treatment has been previously reported (Graaff et al., 2010; Kujawa-Roeleveld et al., 2005). Anaerobic hydrolysis was shown to be the rate limiting when treating black water in a UASB reactor (Graaff et al., 2010).

\subsection{Scheme for black water treatment in source separated sanitation}

The current scheme for treatment of vacuum collected black water in source separated sanitation (SSS) is as described in Figure 1.1a. After collection, black water is anaerobically treated in a UASB reactor for conversion of organic matter into methane gas. Then, the effluent goes to an oxygen-limited autotrophic nitrification-denitrification (OLAND) system for nitrogen removal, and finally, phosphorus is recovered by adding magnesium to precipitate struvite $\left(\mathrm{MgNH}_{4} \mathrm{PO}_{4} \cdot 6 \mathrm{H}_{2} \mathrm{O}\right)$ in an additional step.

The use of a UASB reactor for simultaneous recovery of methane and calcium phosphate granules from black water (Figure 1.1b) was first proposed and reported by Tervahauta et al. (2014c). Thus, little is known about the required conditions which allow and stimulate the formation and growth of calcium phosphate granules and about the impact of calcium phosphate bio granulation on the anaerobic hydrolysis and methane production. 


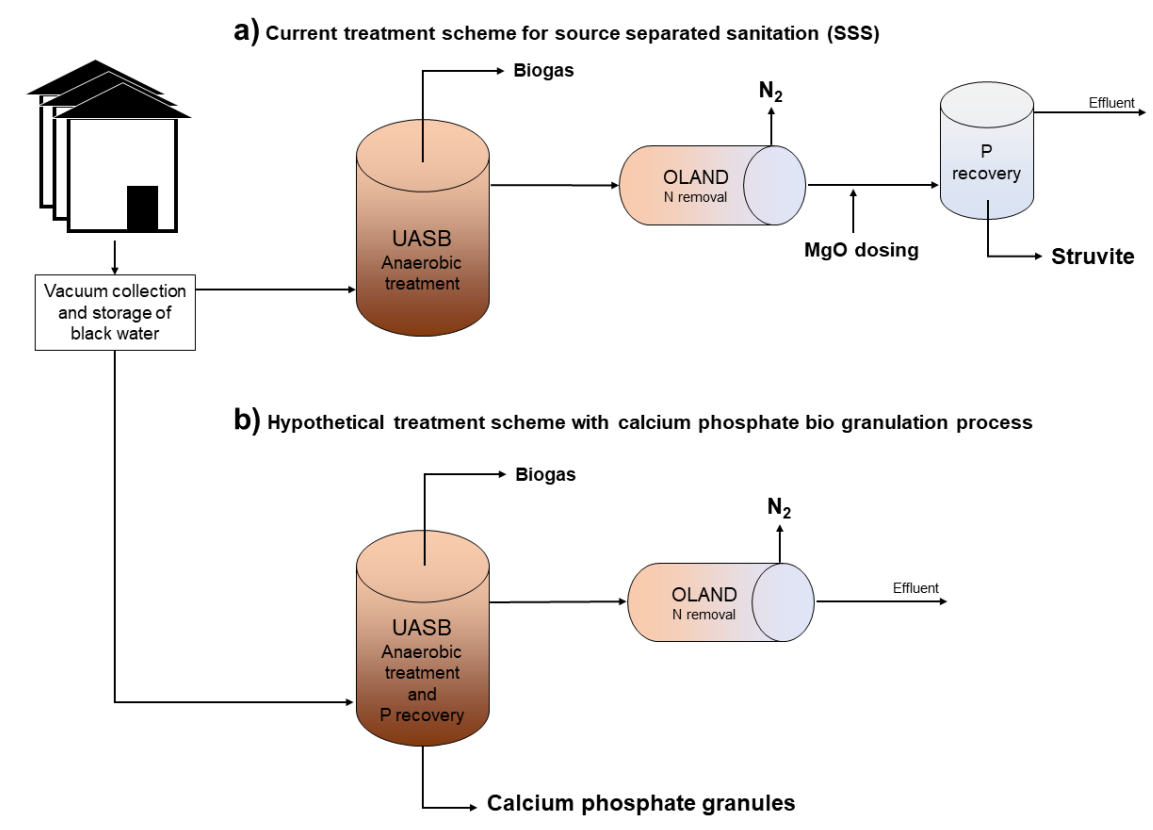

Figure 1.1 Current black water treatment scheme for source separated sanitation (SSS), which is implemented in a neighborhood located in Sneek (the Netherlands) (a), and the hypothetical treatment scheme for black water with anaerobic calcium phosphate bio granulation (b).

\subsection{Calcium phosphate bio granulation}

For the first time, calcium phosphate granules were observed at the bottom of the sludge bed of a UASB reactor treating black water after 500 days of operation (Tervahauta et al., 2014c). The structure of calcium phosphate granules consisted of an outer biofilm $(\sim 100$ $\mu \mathrm{m}$ thick) and a phosphate-rich core, which contained 11 to $13 \mathrm{wt} \%$ of phosphorus and hydroxyapatite $\left(\mathrm{Ca}_{10}\left(\mathrm{PO}_{4}\right)_{6}(\mathrm{OH})_{2}\right.$ and carbonated hydroxyapatite $\left(\mathrm{Ca}_{9.6}\left(\mathrm{PO}_{4}\right)_{5.6}\left(\mathrm{CO}_{3}\right)_{0.7}(\mathrm{OH})_{2}\right)$ were the dominant crystal phases $(\mathrm{Ca} / \mathrm{P}$ molar ratio in the core of 1.81$)$ (Tervahauta et al., 2014c); traces of calcite were also observed. However, because of the early stage of the process and the time required for start-up, the phosphorus recovery as calcium phosphate granules (> $315 \mu \mathrm{m}$ diameter) represented only $2 \%$ of the total incoming P from black water. The potential is much higher though since $\sim 50 \%$ of the incoming phosphorus from black water stayed in the reactor. Moreover, the measured heavy metal and phosphorus contents in calcium phosphate granules complied with the standards for utilization of the granules in the phosphate industry for the production of water-soluble phosphorus (Tervahauta et al., 2014c).

Phosphorus recovery in the current black water treatment scheme occurs via struvite $\left(\mathrm{NH}_{4} \mathrm{MgPO}_{4} \cdot 6 \mathrm{H}_{2} \mathrm{O}\right)$ precipitation by dosing magnesium oxide in a crystallizer, at the end of 
the treatment line (Graaf and Hell, 2014; Graaff et al., 2011a). However, because 50\% of the incoming phosphorus from black water stays in the UASB reactor, the phosphorus recovery efficiency as struvite will remain limited. Moreover, for geographic regions with a high concentration of calcium ions in the tap water used for toilet flushing (> $80 \mathrm{mg} \mathrm{L}^{-1}$, which is the higher limit in the Netherlands), more phosphorus is retained in the UASB reactor, due to the intensification of calcium phosphate formation in the UASB reactor. In this situation, the phosphorus recovery potential as struvite after the UASB reactor would be even lower. Thus, the implementation of calcium phosphate bio granulation for phosphorus recovery within the current treatment scheme for source separated black water has higher recovery potential than struvite and would avoid an additional treatment step.

The hypothesis for the formation of calcium phosphate granules is based on three factors: (1) increase in the calcium concentration in the tap water used for toilet flushing which increased the potential for calcium phosphate precipitation; (2) development of a microenvironment with controlled diffusion of ions by the outer biofilm, which increased the internal $\mathrm{pH}$ and consequently, induced calcium phosphate precipitation in the core, and (3) mixing in the UASB reactor, creating sufficient shear to stimulate formation of granules. Therefore, for further stimulation of formation and growth of calcium phosphate granules attention should be given to thermodynamic aspects for precipitation of calcium phosphate, regarding the black water composition, and to physical and biological aspects behind the creation and growth of granules within UASB reactors, specifically the formation of a biofilm.

\subsubsection{Calcium phosphate crystallization}

Calcium phosphate crystallization depends primarily on the ionic activity of calcium $\left(\mathrm{Ca}^{2+}\right)$, phosphate $\left(\mathrm{PO}_{4}{ }^{3-}\right)$, and hydroxide $\left(\mathrm{OH}^{-}\right)$, which is a reference for solution $\mathrm{pH}$ (Song et al., 2002). These constituent ions, when exceeding a solubility product, first form a nuclei that grow and can further evolve into a crystalline structure. In solution, phosphorus can be present as $\mathrm{H}_{3} \mathrm{PO}_{4}$ (acid), $\mathrm{H}_{2} \mathrm{PO}_{4}{ }^{-}$(weak acid), $\mathrm{HPO}_{4}{ }^{2-}$ (weak base), and $\mathrm{PO}_{4}{ }^{3-}$ (base), depending on the solution $\mathrm{pH}$ (Montastruc et al., 2004). For calcium phosphate precipitation, $\mathrm{PO}_{4}{ }^{3-}$ is the most relevant, since it is the form used for formation of hydroxyapatite $\left(\mathrm{Ca}_{10}\left(\mathrm{PO}_{4}\right)_{6}(\mathrm{OH})_{2}\right)$, according to eq. 1.1. Precipitation, as a chemical reaction, involves a change in the Gibbs free energy $(\Delta G)$, which is the indicator for the feasibility (spontaneity) of precipitation of a certain compound (Mullin, 2001). In other words, $\Delta G$ is the driving force for the precipitation. For calcium phosphate precipitation the Gibbs free energy is defined as described in eq. 1.2. 
$10 \mathrm{Ca}^{2+}+6 \mathrm{PO}_{4}^{3-}+2 \mathrm{OH}^{-} \rightarrow \mathrm{Ca}_{10}\left(\mathrm{PO}_{4}\right)_{6} \mathrm{OH}_{2}$

$\Delta G=-k T \ln \left(\frac{\left[\mathrm{Ca}^{2+}\right]^{10}\left[\mathrm{PO}_{4}^{3-}\right]^{6}\left[\mathrm{OH}^{-}\right]^{2}}{K_{S p} \text { (hydroxyapatite) }}\right)$
Equation 1.1

where $k$ is the Boltzmann constant, $T$ is the temperature, $K_{s p}$ is the thermodynamic solution product of hydroxyapatite, and $\left[\mathrm{Ca}^{2+}\right],\left[\mathrm{PO}_{4}^{3-}\right]$, and $\left[\mathrm{OH}^{-}\right]$are the ionic activities of each compound needed for the formation of hydroxyapatite.

When $\Delta G$ is negative there is enough energy for precipitation, so the solution is supersaturated with respect to hydroxyapatite. Formation of hydroxyapatite does not happen when $\Delta G$ is positive, so the solution is undersaturated. However, eq 1.2 only includes the thermodynamic equilibrium. Several other factors may influence the formation of hydroxyapatite. For instance, another important aspect for precipitation of calcium phosphate is the crystallization kinetics, or the time required for the precipitation to occur (Mullin, 2001). For the crystallization kinetics, besides the ionic activity products and temperature other parameters should be considered, such as competing species (e.g., calcium carbonate and struvite), surface availability and properties, and presence of catalyzers and inhibitors (Cao and Harris, 2008).

Apatite is the most thermodynamically stable calcium phosphate phase. However, formation of apatite involves pre-formation of less stable and kinetically more accessible precursor phases, such as amorphous calcium phosphate (generally represented as $\mathrm{Ca}_{9}\left(\mathrm{PO}_{4}\right)_{6}$ ${ }_{x}\left(\mathrm{HPO}_{4}\right)_{x}(\mathrm{OH})_{x}$, where $x$ is dependent on solution conditions) and octacalcium phosphate $\left(\mathrm{Ca}_{8} \mathrm{H}_{2}\left(\mathrm{PO}_{4}\right)_{6} \cdot 5 \mathrm{H}_{2} \mathrm{O}\right)$ (Combes and Rey, 2010; Habraken et al., 2013). The nucleation of amorphous calcium phosphate involves the assembly of calcium triphosphate complexes $\left(\mathrm{Ca}\left(\mathrm{HPO}_{4}\right)_{3}{ }^{4-}\right)$ by incorporation of $\mathrm{Ca}^{2+}$ ions at $20^{\circ} \mathrm{C}$ and $\mathrm{pH}$ below 7.5 (Habraken et al., 2013). Then, the amorphous clusters evolve to larger spheres containing octacalcium phosphate ribbons, which are the direct precursors of nanocrystalline apatite, according to the Ostwald rule (Combes and Rey, 2010; Habraken et al., 2013; Santen, 1984; Xie et al., 2014). At alkaline $\mathrm{pH}$ (> 10), amorphous calcium phosphate evolves directly to apatite, as the $\mathrm{PO}_{4}{ }^{3-}$ activity in solution starts to increase (Combes and Rey, 2010). At neutral pH (7 to 7.5), the formed apatite nanocrystals $(\sim 5 \mathrm{~nm})$ aggregate within spheres $(\sim 1 \mu \mathrm{m})$ composed of amorphous calcium phosphate and transition phases (Bian et al., 2012). The spheres agglomerate further to form larger units (Bar-Yosef Ofir et al., 2004). Because the influent and effluent pH of black water 
anaerobic treatment is between 7 and 9 (Graaff et al., 2010), the formation of apatite at neutral $\mathrm{pH}$ is the most interesting for calcium phosphate bio granulation.

A large set of compounds, such as organic polymers, humic substances, foreign ions, and enzymes, are known to interfere with the formation of calcium phosphate (Bar-Yosef Ofir et al., 2004; Cao and Harris, 2008; Nijhuis et al., 2014; Song et al., 2006a). Depending on the environmental solution conditions, their role can be positive by catalyzing the formation of calcium phosphate, or negative by blockage of active sites within the formed crystals (retarding the crystallization) and by ion substitution (e.g., replacement of $\mathrm{HPO}_{4}{ }^{2-}$ for $\mathrm{CO}_{3}{ }^{2-}$ during apatite crystallization). Thus, special attention should be given to environmental solution conditions to understand the driving forces for formation and agglomeration of calcium phosphate in the granules.

\subsubsection{Granulation in upflow bioreactors}

Commonly, granulation occurs by agglomeration of microorganisms and extracellular polymeric substances as a consequence of a selection pressure, which can be exerted by several factors, such as upflow velocity, feed type, and feed loading rate, among others (Liu et al., 2002; Pereira et al., 2002; Schmidt and Ahring, 1996; Sudmalis et al., 2018).

A major factor leading to granulation is the relatively high liquid upflow velocity (generally $>1 \mathrm{~m} \mathrm{~h}^{-1}$ ) achieved by utilization of UASB technology (Hulshoff Pol et al., 2004). The hydrodynamic shear stress applied to the microbial community forces the washout of light biomass and promotes the selective retention of heavier biomass agglomerates (Schmidt and Ahring, 1996). However, for wastewater with a relatively high concentration of particulate organic matter the commonly applied upflow velocity can lead to unwanted washout of undigested organic solids (Mahmoud et al., 2003). About $60 \%$ of the organic loading in black water is solid (Tervahauta et al., 2014a). Moreover, the reported upflow velocity during treatment of black water in a UASB reactor was between 0.23 and $0.76 \mathrm{~cm} \mathrm{~h}^{-1}$, which is 100 to 400 times lower than that commonly used for anaerobic granulation of industrial wastewater (Graaff et al., 2010; Hulshoff Pol et al., 2004; Tervahauta et al., 2014c). During anaerobic treatment of wastewater with a fraction of organic suspended material, such as black water, good settling flocculent sludge instead of granular sludge is produced (Graaff et al., 2010; Zeeman and Lettinga, 1999). Thus, the hydrodynamic driving force for common anaerobic granulation is not the driving force for calcium phosphate bio granulation during anaerobic black water treatment.

Regarding the feed type, high-energy feed, such as sugars and carbohydrates, are known to stimulate the production of extracellular biopolymers, which act as gluing agents 
leading to biomass agglomeration and ultimately to granulation (Hulshoff Pol et al., 2004; Schmidt and Ahring, 1994). Granules grown on low-energy feeds, such as acetate, are generally weaker in strength due to the lower production of extracellular biopolymers (Liu et al., 2002; Schmidt and Ahring, 1994). The loading rate also plays a role in granulation (Ghangrekar et al., 2005). Black water contains high-energy containing compounds, such as carbohydrates, proteins, and lipids (Penn et al., 2018). The VFA concentration in black water represents in average only $10 \%$ of the total chemical oxygen demand (COD) (Tervahauta et al., 2014a).

Granulation has been extensively studied, and several theories for granulation have been proposed besides the aforementioned selective pressures (Hulshoff Pol et al., 2004). The theories for granulation can be divided into thermodynamic and structural models according to Liu et al. (2002). Thermodynamic models are based on attractive van der Waals force, DLVO theory, which consists of reversible adhesion at the secondary minimum (positive $\Delta G$ ) at approximately $5 \mathrm{~nm}$ distance between two microorganisms, and cell-to-cell contact promoted by mutual hydrophobicity. Structural models are based on physiological and organizational aspects behind the formation of the first nuclei, the interaction between microorganisms (e.g., proton translocation), and the bonding of microorganisms with produced extracellular biopolymers and cations.

\subsubsection{Stimulants for granulation}

Naturally, the seed sludge is an important aspect for granulation start-up. Generally, denser and relatively inactive sludge is preferable over lighter and dispersed sludge, due to the higher tendency for washout of the latter (Liu et al., 2002). Seeding with already granular sludge is often advantageous, because the required microbial community and the structural properties for granulation may be already developed (Hulshoff Pol et al., 2004). Seed granular sludge with a mixed microbial community grew faster when compared to granular sludge containing mainly methanogens or mainly acidogens, indicating that syntrophy plays a significant role in granulation (Batstone et al., 2004; El-Mamouni et al., 1997; Liu et al., 2002). Seed particles, such as granular and powdered activated carbon and zeolite seeds, can serve as carriers for microbial attachment, promoting the development of biofilm and further growth to granules (Hulshoff Pol et al., 2004; Sudmalis et al., 2018; Yu et al., 1999). Moreover, polymeric substances, such as cationic polymers, and cations, such as $\mathrm{Ca}^{2+}, \mathrm{Fe}^{2+/ 3+}, \mathrm{Al}^{3+}$, and $\mathrm{Mg}^{2+}$, are also known to stimulate granulation, due to the bridging capacity (Dang et al., 2014; Show et al., 2004; Tiwari et al., 2006; Wirtz and Dague, 1996; Yu et al., 2001). These 
stimulants might be used to induce and intensify calcium phosphate bio granulation during black water treatment.

\subsubsection{Heavy metals, micropollutants, pathogens}

The composition of black water (feces plus urine) is considerably influenced by anthropogenic factors, such as diet, consumption of medicines, disposal of pharmaceuticals and household cleaning products into the toilet, and dilution at the collection. The concentration of pollutants (heavy metals and micropollutants) have a direct impact on the reusability of nutrients from black water. Tervahauta et al. (2014b) analyzed the load of heavy metals in black water and showed that heavy metals in human excreta are originated from primary dietary sources, resulting in lower levels of heavy metals in anaerobic black water sludge when compared to conventional sewage sludge. Thus, application of black water sludge on soil over animal manure and artificial fertilizers could further reduce the heavy metal content in the soil/food cycle (Tervahauta et al., 2014b). Regarding micropollutants, Butkovskyi et al. (2015) found that during anaerobic treatment of black water in a UASB reactor about $70 \%$ of 9 out of 12 pharmaceuticals were removed by conversion and two were removed by sorption into the sludge. Composting of black water sludge increases further the removal of micropollutants, enabling the use of black water sludge as soil amendment (Butkovskyi et al., 2016). Concerning pathogens, the average removal during anaerobic digestion is $2 \log$ (Avery et al., 2014; Horan et al., 2004). The revised regulation for fertilizing products stipulates defined operational temperatures during production of digestate (sludge from anaerobic digestion) to ensure removal of pathogens (European Commission, 2016). According to the regulation, thermophilic $\left(55^{\circ} \mathrm{C}\right)$ anaerobic digestion with a hydraulic retention time of 20 days or mesophilic $\left(37^{\circ} \mathrm{C}\right.$ to $\left.40^{\circ} \mathrm{C}\right)$ digestion including a pasteurization step at $70^{\circ} \mathrm{C}$ for one hour are possible options to enable the use of digested sludge as fertilizer (European Commission, 2016). 


\subsection{Scope and thesis outline}

Calcium phosphate bio granulation in the UASB reactor is a promising process for simultaneous recovery of phosphate and methane from source separated black water in a single treatment step. The goal of this thesis is to understand the fundamental mechanism behind calcium phosphate bio granulation and to explore technological options for enhancing the phosphate recovery efficiency. The intended end use of the calcium phosphate granules is application in agriculture as fertilizer and application in the fertilizer industry as a replacement for natural phosphate rock to produce water-soluble phosphate.

The calcium phosphate bio granulation process was reproduced in a lab scale UASB reactor. In Chapter 2, the results from the monitoring of influent and effluent parameters revealed that $\mathrm{PO}_{4}{ }^{3-}$ removal is dependent on the $\mathrm{Ca}^{2+}$ concentration in black water, which in turn is dependent on the $\mathrm{HCO}_{3}{ }^{-}$concentration. The change in black water was seasonal and showed that $\mathrm{Ca}^{2+}$ is limiting phosphorus accumulation, and consequently, calcium phosphate bio granulation.

Because $\mathrm{Ca}^{2+}$ is a limiting factor, additional $\mathrm{Ca}^{2+}$ was added to a UASB reactor treating black water. In Chapter 3, it is shown that the added $\mathrm{Ca}^{2+}$ increased the retention of phosphorus in the reactor and stimulated the calcium phosphate bio granulation, contributing to a significant increase in the phosphorus recovery efficiency.

In Chapter 4, the fundamental mechanism behind the formation of calcium phosphate granules is presented. An increasing $\mathrm{pH}$ gradient from the edge to the granule center was measured. The $\mathrm{pH}$ gradient triggers internal supersaturation for calcium phosphate phases, favoring enrichment of phosphorus in the granules over bulk precipitation. It is proposed that conversion of $\mathrm{H}_{2}, \mathrm{H}^{+}$, and $\mathrm{HCO}_{3}{ }^{-}$into $\mathrm{CH}_{4}$ in the outer biofilm creates the micro-environment in the granules. Furthermore, the maturation of calcium phosphate granules is described according to image analysis and chemical composition of different granule sizes.

Calcium phosphate bio granulation under synthetic conditions is presented in Chapter 5. Black water was replaced by a synthetic media with a similar chemical matrix as black water, but different carbon source (viz. glucose and volatile fatty acids). Additionally, the bulk pH was controlled between 7.5 and 8 to confirm the importance of the $\mathrm{pH}$ gradient. At bulk $\mathrm{pH} 8$, the $\mathrm{pH}$ gradient from the edge to the center of the granule is expected to be disrupted. Extracellular biopolymers were measured to study their function in calcium phosphate bio granulation. A comparison between granules formed with glucose and black water is presented and discussed. 
In Chapter 6, the operation and performance of a novel reactor design, combining upflow anaerobic sludge blanket and internal recirculation gas-lift concepts, named UASBGL reactor, are described. The internal mixing by gas injection enhanced the concentration of phosphorus at the location where calcium phosphate granules are expected to be harvested. Moreover, gentile shear applied by the gas lifting force increased the weight percentage of phosphorus in the granules which is essential for their application.

The calcium phosphate granules harvested in the novel reactor were characterized. In Chapter 7, the elemental composition, crystallographic properties, heavy metal content, presence and concentration of micropollutants, and phosphate dissolution capacity of calcium phosphate granules are presented. Additionally, application in agriculture and as replacement of phosphate rock in fertilizer industry is discussed.

In Chapter 8, the summary of the main results of this thesis, possible improvements, the integration of calcium phosphate bio granulation within the current source separation sanitation concept, and an outlook for the potential impact of calcium phosphate bio granulation on phosphorus recovery are discussed. 


\section{Chapter 2. Simultaneous recovery of calcium phosphate granules and methane in anaerobic treatment of black water: effect of bicarbonate and calcium fluctuations}

J. R. Cunha, T. Tervahauta, R. D. van der Weijden, L. Hernández Leal, G. Zeeman, C. J. N. Buisman

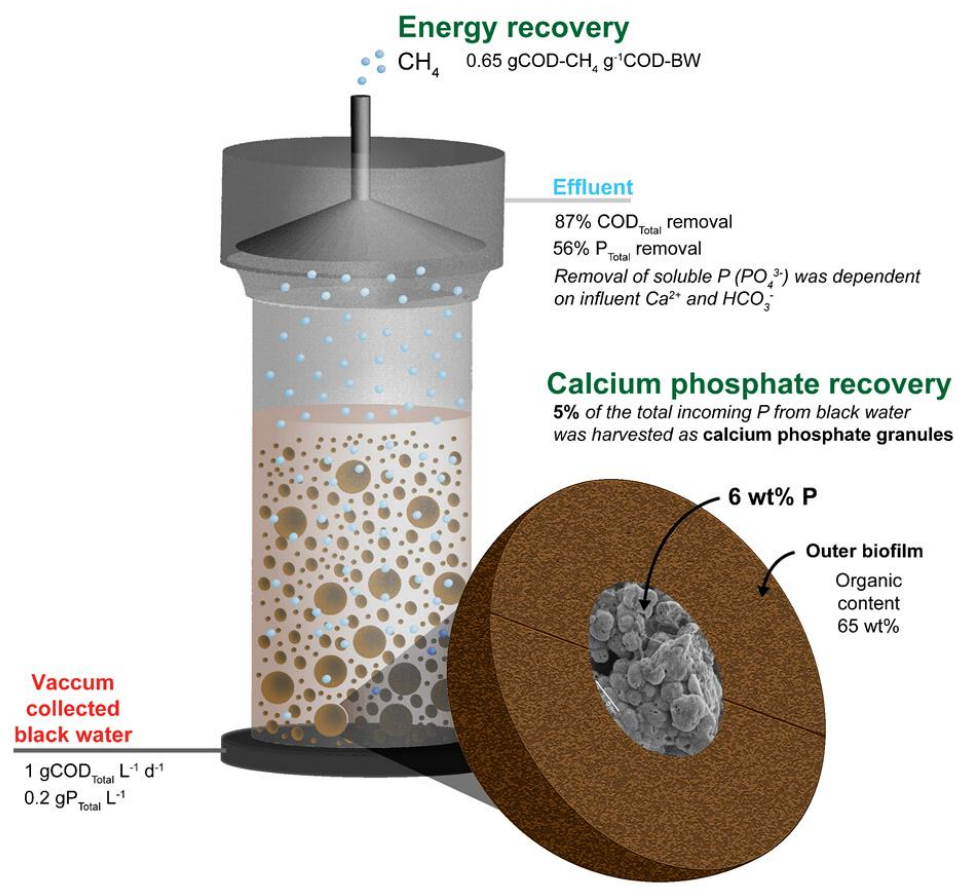

This chapter was published as:

J. R. Cunha, T. Tervahauta, R. D. van der Weijden, L. Hernández Leal, G. Zeeman, C. J. N. Buisman, 2017. Simultaneous recovery of calcium phosphate granules and methane in anaerobic treatment of black water: Effect of bicarbonate and calcium fluctuations. Journal of Environmental Management. 216. 399-405. 


\begin{abstract}
Calcium phosphate $(\mathrm{CaP})$ granules were discovered in the anaerobic treatment of vacuum collected black water (BW), using upflow anaerobic sludge blanket (UASB) technology. This allows simultaneous recovery of $\mathrm{CaP}$ granules and methane in the UASB reactor. However, the role of $\mathrm{BW}$ composition on $\mathrm{CaP}$ granulation is not yet understood. Moreover, $\mathrm{CaP}$ granulation was not observed in previous research on anaerobic treatment of BW, although similar treatment conditions were applied. Therefore, this study shows specifically the influence of bicarbonate and calcium fluctuations in BW on the phosphorus accumulation in the UASB reactor, which directly affects $\mathrm{CaP}$ granulation. Without calcium addition, $5 \%$ of the total phosphorus $(\mathrm{P})$ fed was found as $\mathrm{CaP}$ granules in the reactor $(61 \mathrm{mgP}$ $\mathrm{g}^{-1}$ dried matter), after 260 days of operation. Simultaneously, $65 \%$ of the COD in BW was efficiently converted into methane at $25^{\circ} \mathrm{C}$. Variations of bicarbonate and calcium concentrations in raw BW showed a significant influence on phosphorus accumulation in the UASB reactor. Geochemical modelling showed that the increase of soluble calcium from 39 to $54 \mathrm{mg} \mathrm{L}^{-1}$ in $\mathrm{BW}$ triggers supersaturation for calcium phosphate precursors $\left(\mathrm{Ca}_{\mathrm{x}}\left(\mathrm{PO}_{4}\right)_{\mathrm{y}}\right)$. Concurrently, bicarbonate decreased from 2.7 to $1.2 \mathrm{~g} \mathrm{~L}^{-1}$, increasing further the ionic activity of calcium. Formation and accumulation of seed particles possibly enhanced $\mathrm{CaP}$ granulation. Preliminary results showed that addition of calcium $\left(\mathrm{Ca}^{2+} / \mathrm{PO}_{4}{ }^{3-}\right.$ molar ratio of 3$)$ increases the accumulation of total $\mathrm{P}$ in the UASB reactor to more than $85 \%$. This further increases the granulation rate and consequently, the process feasibility.
\end{abstract}




\subsection{Introduction}

Phosphate $\left(\mathrm{PO}_{4}{ }^{3-}\right)$ is finite and essential for humankind, and $88 \%$ of the rock phosphate reserves are predicted to be controlled by Morocco in the early $22^{\text {nd }}$ century (Cooper et al., 2011). Introduction of recycling measures and sustainable use can extend the global resource longevity beyond the $22^{\text {nd }}$ century (Koppelaar and Weikard, 2013). Source separated black water (BW) contains $75 \%$ of the domestically wasted phosphorus (P) (Tervahauta et al., 2013). Thus, $\mathrm{P}$ recovery from $\mathrm{BW}$ could significantly extend $\mathrm{PO}_{4}{ }^{3-}$ availability. The relatively high concentration of $\mathrm{P}$ and organics is achieved by vacuum collection of $\mathrm{BW}(0.19 \pm 0.08 \mathrm{gP}$ $\mathrm{L}^{-1}$ and $8 \pm 2 \mathrm{gCOD} \mathrm{L}^{-1}$ ), which consumes much less water when compared with the conventional toilet flushing system (6 and $34 \mathrm{~L}_{\text {person }}{ }^{-1} \mathrm{~d}^{-1}$ of water use, respectively) (Tervahauta et al., 2013). The separate treatment of BW creates attractive conditions for implementation of recovery techniques as demonstrated at full scale by Graaf and Hell (2014).

The existing treatment concept of BW consists of an upflow anaerobic sludge blanket (UASB) reactor for COD removal and methane $\left(\mathrm{CH}_{4}\right)$ production, followed by an oxygenlimited autotrophic nitrification-denitrification (OLAND) reactor for nitrogen removal, and finally a $\mathrm{P}$ removal stage where magnesium oxide $(\mathrm{MgO})$ is added to induce struvite precipitation (Graaf and Hell, 2014; Tervahauta et al., 2013). This concept has been applied at full scale since 2008 for a community with 232 houses in Sneek, (the Netherlands) (Graaf and Hell, 2014).

At $25{ }^{\circ} \mathrm{C}, 54 \%$ of the organic load is converted into biogas in the UASB reactor with a hydraulic retention time (HRT) of 8.7 days and an organic loading rate (OLR) of $1 \mathrm{kgCOD}$ $\mathrm{m}^{-3} \mathrm{~d}^{-1}$ (Graaff et al., 2010), 85\% of the nitrogen is removed in the OLAND reactor (Graaff et al., 2011b) and 56\% of the total $\mathrm{P}$ is precipitated as struvite in a subsequent reactor (Graaff et al., 2011a). However, a large fraction of P (39\%) accumulated in the UASB reactor (Graaff et al., 2011a). Moreover, the accumulation of $\mathrm{P}$ increased from 39 to $51 \%$ after a decrease in bicarbonate $\left(\mathrm{HCO}_{3}{ }^{-}\right)$and an increase in soluble calcium $\left(\mathrm{Ca}^{2+}\right)$ in BW (Graaff et al., 2011a; Tervahauta et al., 2014c). This change was most likely due to changes in drinking water composition and dilution of BW (Graaff et al., 2011a; Mulder et al., 2014). The increase in P accumulation coincided in time with formation of calcium phosphate granules (CaP granules) in the UASB reactor, most likely due to the intensified accumulation of calcium phosphate $\left(\mathrm{Ca}_{\mathrm{x}}\left(\mathrm{PO}_{4}\right)_{\mathrm{y}}\right)$ particles which seeded $\mathrm{CaP}$ granulation (Tervahauta et al., 2014c). Because $\mathrm{P}$ recovery as struvite has a limited yield due to $\mathrm{P}$ accumulation in the UASB reactor, the recovery of $\mathrm{CaP}$ granules is a process with higher potential. Moreover, it allows the 
simultaneous recovery of $\mathrm{P}$ and methane from $\mathrm{BW}$ in a single reactor. To increase the recovery of $\mathrm{CaP}$ granules and to made the struvite step obsolete, more insight into the influence of $\mathrm{HCO}_{3}{ }^{-}$and $\mathrm{Ca}^{2+}$ in $\mathrm{BW}$ on $\mathrm{P}$ accumulation is crucial.

Therefore, this study evaluates the effect of fluctuations of $\mathrm{HCO}_{3}{ }^{-}$and $\mathrm{Ca}^{2+}$ in $\mathrm{BW}$ on accumulation of $\mathrm{P}$, during the anaerobic treatment of BW using a UASB reactor. The effect of these fluctuations on the supersaturation state of $\mathrm{Ca}_{\mathrm{x}}\left(\mathrm{PO}_{4}\right)_{\mathrm{y}}$ phases in $\mathrm{BW}$ is assessed with correlations between chemical measurements and geochemical modelling. Simultaneously, the physical and chemical development of the sludge bed and treatment performance is monitored. Additionally, $\mathrm{CaP}$ granules are quantified and characterized. Finally, $\mathrm{Ca}^{2+}$ is added in treated BW (effluent from the UASB reactor) to predict its potential effect on the P accumulation.

\subsection{Materials and methods}

\subsubsection{Experimental set up}

A UASB reactor (5 L) fed with vacuum collected BW was started and monitored for 260 days at $25^{\circ} \mathrm{C}$, with a HRT of 8 days and a total OLR of $1 \mathrm{kgCOD} \mathrm{m}^{-3} \mathrm{~d}^{-1}$. The HRT of 8 days was chosen at a temperature of $25^{\circ} \mathrm{C}$ in order to have a similar upflow velocity and solids retention time (SRT) as achieved by Tervahauta et al. (2014c). The reactor was inoculated with $2 \mathrm{~L}$ of sludge from the aforementioned full scale UASB reactor (Graaf and Hell, 2014). Respectively, one and two times per week, influent and effluent were sampled and analysed for total and volatile suspended solids (TSS and VSS, respectively), chemical oxygen demand (COD), elements ( $\mathrm{P}, \mathrm{Ca}, \mathrm{Mg}, \mathrm{Na}$, and $\mathrm{K}$ ), $\mathrm{PO}_{4}{ }^{3-}$, volatile fatty acids (VFA), and ammonium $\left(\mathrm{NH}_{4}{ }^{+}\right)$. Sludge bed analysis at $5 \mathrm{~cm}$ from the bottom of the UASB reactor was performed approximately every 30 days. Sludge was taken for each sampling point $(100 \mathrm{ml})$ and analysed for TSS, VSS, P, Ca, Mg, Na, and K. Duplicates were performed for influent, effluent, and sludge analyses.

\subsubsection{Physical and chemical analyses}

TSS and VSS were quantified according to the standard methods (Clesceri et al., 1998). Total and soluble COD were measured with cuvette tests Hach Lange (LCK114). Biogas composition was analysed through gas chromatography (Varian CP4900 Micro GC with two separate column models Mol Sieve $5 \AA$ PLOT (MS5) and PoraPLOT U (PPU)). Liquid and solid elemental analyses ( $\mathrm{P}, \mathrm{Ca}, \mathrm{Mg}, \mathrm{Na}$, and $\mathrm{K}$ ) of influent, effluent, and sludge samples were performed through inductively coupled plasma - optical emission spectrometry (ICP-OES Perkin Elmer Optima $5300 \mathrm{DV}$ ). An acid digestion at $148{ }^{\circ} \mathrm{C}$ for 45 min was 
performed beforehand to dissolve solids. $\mathrm{PO}_{4}{ }^{3-}$ and volatile fatty acids (VFA) were quantified through ion chromatography (Metrohm 761 Compact IC, for VFA determination Silica Gel with $\mathrm{C} 18$ alkyl groups as carrying material was used). Ammonium $\left(\mathrm{NH}_{4}^{+}\right)$was analysed using cuvette tests Hach Lange (LCK302). Soluble compounds were measured after membrane filtration $\left(0.45 \mu \mathrm{m}\right.$ Cronus filter PTFE). $\mathrm{HCO}_{3}{ }^{-}$was calculated according to standard methods (Tchobanoglous et al., 2004), using the inorganic carbon (IC) concentration, which was measured with a Shimadzu TOC analyser, and the $\mathrm{pH}$ at $25^{\circ} \mathrm{C}$. SRT, level of hydrolysis of solids, and methanization were calculated according to Graaff et al. (2010), for the steady state period between days 55 and 260. A vertical characterization of the sludge bed at 5, 10, 20, and $30 \mathrm{~cm}$ high was performed at the end of the monitoring period (day 260). In this characterization, TSS, VSS, and COD concentrations and P, Ca, and Mg contents in TSS were measured.

\subsubsection{Separation and characterization of calcium phosphate granules}

$\mathrm{CaP}$ granules were quantified through a separation by specific density of particles from sludge bed samples $(100 \mathrm{ml})$. These were taken on days 218 and 300 at two different heights of the UASB reactor ( 5 and $20 \mathrm{~cm}$ ). The separation of CaP granules in these samples was carried out in an upflow column $(100 \times 2 \mathrm{~cm})$, using paper (black ribbon ashless Schleicher $\&$ Schuell) filtered effluent from the UASB reactor to fluidize the sample. An upflow velocity of $57 \mathrm{~m} \mathrm{~h}^{-1}$ was applied and solids were divided in 5 fractions by density. Solids from the densest fraction were considered as $\mathrm{CaP}$ granules, due to the higher specific density (inorganic content) and size compared to organic sludge and smaller inorganic particles. Elements (P, Ca, and $\mathrm{Mg}$ ), TSS, and VSS were determined for each fraction in the separation column. The procedure was performed twice for each height sampled. The morphology and elemental distribution of $10 \mathrm{CaP}$ granules were analysed with a scanning electron microscope in backscattering mode coupled with energy dispersive X-ray (SEM-EDX). The crystal phases in the granules were identified through X-ray diffraction (XRD) analysis.

\subsubsection{Phosphorus mass balance}

The $\mathrm{P}$ mass balance was calculated by adding up the entire measured incoming total $\mathrm{P}$ (influent and inoculum) and measured outgoing (accumulated, effluent, and sampled). The accumulated $\mathrm{P}$ was calculated according the eq. 2.1. The accumulated $\mathrm{P}$ was further divided in $\mathrm{CaP}$ granules, organic sludge, and inorganic particles. The fraction $\mathrm{CaP}$ granules was calculated according to the eq. 2.2. The fraction organic sludge was calculated according to eq. 2.3. The fraction inorganic particles was calculated according to eq. 2.4. The P recovery as 
$\mathrm{CaP}$ granules was estimated according to the $\mathrm{P}$ content of $\mathrm{CaP}$ granules in the sludge bed after the monitoring period. The fraction non-quantifiable consists of $\mathrm{P}$ accumulation at the bottom of the reactor and $\mathrm{P}$ precipitation directly in the inlet tube, perhaps due to the low feeding flow (Rohde, 2016).

$$
\begin{array}{ll}
P_{\text {accumulated }}=\sum_{i}\left(P_{T_{i}} \cdot T S S_{i} \cdot V_{s} / h_{i}\right) & \text { Equation } 2.1
\end{array}
$$

where $i$ represents the four heights of the sludge bed sampled $(i=5,10,20$, and $30 \mathrm{~cm}), P_{T}$ is the $\mathrm{P}$ content in TSS $\left(\mathrm{g} \mathrm{g} \mathrm{g}^{-1}\right)$, TSS is the concentration of suspended solids $\left(\mathrm{g} \mathrm{L}^{-1}\right), V_{S}$ is the sludge bed volume (L) on day 260 , and $h$ is the volume fraction for each height $(0.17,0.17$, 0.22 , and $0.44\left(\mathrm{~L} \mathrm{~L}^{-1}\right)$ for $5,10,20$, and $30 \mathrm{~cm}$, respectively).

$P_{\text {CaP granules }}=P_{T_{5}} \cdot f_{5} \cdot T S S_{5} \cdot V_{S_{5}}+P_{T_{20}} \cdot f_{20} \cdot T S S_{20} \cdot V_{S_{20}} \quad$ Equation 2.2

where 5 and 20 are the two heights of the sludge bed sampled for particle separation ( 5 and 20 $\mathrm{cm}), P_{T}$ is the $\mathrm{P}$ content in TSS $\left(\mathrm{g} \mathrm{g}^{-1}\right)$ from the densest fraction (CaP granules) of each height, $f$ is the percentage of TSS from the sludge sample as CaP granules, TSS is the concentration of TSS in the sludge sample $\left(\mathrm{g} \mathrm{L}^{-1}\right)$ and $V_{S}$ is the volume fraction of the sludge bed for each height sampled (1 and $1.3 \mathrm{~L}$ for 5 and $20 \mathrm{~cm}$, respectively).

$P_{\text {Organic Sludge }}=P_{I} \cdot \sum_{i}\left(V S S_{i} \cdot V_{s} / h_{i}\right)$

Equation 2.3

where $P_{I}$ is the initial $\mathrm{P}$ content in VSS of the inoculum $\left(26 \mathrm{mgP} \mathrm{gVSS}^{-1}\right), V S S$ is the concentration of volatile suspended solids $\left(\mathrm{g} \mathrm{L}^{-1}\right)$ for each height of the sludge bed $(i=5,10$, 20, and 30) and $V_{s} / h_{i}$ is defined as aforementioned for the $\mathrm{P}$ accumulated.

$P_{\text {inorganic particles }}=P_{\text {accumulated }}-P_{\text {Organic Sludge }}-P_{\text {CaP granules }} \quad$ Equation 2.4

\subsubsection{Ionic activity and saturation state calculations}

Precipitation of $\mathrm{Ca}_{\mathrm{x}}\left(\mathrm{PO}_{4}\right)_{\mathrm{y}}$ and $\mathrm{CaCO}_{3}$ species in $\mathrm{BW}$ and treated $\mathrm{BW}$ was evaluated according to the saturation index (SI), using the software Visual MINTEQ version 3.1 (KTH, Sweden). The software considers the Davies model to calculate the activity coefficients (Mullin, 2001). SI of a certain specie (y) was calculated through the ratio $I A P_{y} / K_{s p_{y}}$, where $I A P$ is the ion activity product of the elements in y and $K_{s p}$ is the solubility product constant of $\mathrm{y}$. For SI $>1 \mathrm{y}$ is supersaturated, for $\mathrm{SI}<1 \mathrm{y}$ is under saturation and for $\mathrm{SI}=1 \mathrm{y}$ is in apparent equilibrium. The chemical matrix $\left(\mathrm{Ca}^{2+}, \mathrm{Mg}^{2+} \cdot \mathrm{Na}^{+}, \mathrm{K}^{+}, \mathrm{PO}_{4}{ }^{3-}, \mathrm{HCO}_{3}{ }^{-}\right.$(alkalinity), $\mathrm{Cl}^{-}$ , $\mathrm{SO}_{4}{ }^{2-}$, soluble humic acids, and $\mathrm{pH}$ ) of $\mathrm{BW}$ and treated $\mathrm{BW}$ was used to define the model components. 


\subsubsection{Experimental set-up for $\mathrm{Ca}^{2+}$ addition in treated black water}

$\mathrm{CaCl}_{2}$ was added in treated $\mathrm{BW}$ (effluent from the UASB reactor) batches $(5 \mathrm{~L})$, containing $43 \mathrm{mgPO}_{4}{ }^{3-}-\mathrm{P} \mathrm{L}^{-1}$, at different $\mathrm{Ca}^{2+} / \mathrm{PO}_{4}{ }^{3-}$ molar ratios $(1.5,3.1$, and 4.8$)$ in $1 \mathrm{~L}$ recirculation columns. A control was run with only treated $\mathrm{BW}\left(0.6 \mathrm{Ca}^{2+} / \mathrm{PO}_{4}{ }^{3-}\right.$ molar ratio $)$. The formed precipitates were accumulated in the column with a hydraulic retention time (HRT) of 5.5 h. During 12 days, $\mathrm{PO}_{4}{ }^{3-}, \mathrm{Ca}^{2+}$, and $\mathrm{HCO}_{3}{ }^{-}$concentrations and $\mathrm{pH}$ in the liquid phase were measured.

\subsection{Results and discussion}

\subsubsection{Anaerobic treatment performance}

The UASB reactor performance was based on total COD removal and $\mathrm{CH}_{4}$ production (Table 2.1). More than $80 \%$ of the total COD loading was removed with a methanization rate of $65 \pm 26 \%$. Approximately $91 \%$ of the suspended COD $\left(\mathrm{COD}_{\mathrm{ss}}\right)$ was removed with a hydrolysis level of $65 \pm 34 \%$ (fraction of $\mathrm{COD}_{\mathrm{ss}}$ converted into $\mathrm{CH}_{4}$ ). This resulted in a SRT of 316 days. The effluent was nearly free of solids $\left(<0.5 \mathrm{gCOD}_{\mathrm{ss}} \mathrm{L}^{-1}\right)$. Sludge discharge stabilized after 55 days of operation at $0.5 \pm 0.1 \mathrm{gVSS} \mathrm{d}^{-1}\left(0.6 \pm 0.2 \mathrm{gTSS} \mathrm{d}^{-1}\right)$, corresponding to a sludge yield of $0.12 \mathrm{gVSS} \mathrm{g}^{-1}$ of COD removed. The concentration of volatile fatty acids (VFA) in the effluent was always below $0.05 \mathrm{~g} \mathrm{~L}^{-1}$. The $\mathrm{CH}_{4}$ production was $1.9 \mathrm{~L} \mathrm{~L}^{-1}$ of BW, at $25^{\circ} \mathrm{C}$. Graaff et al. (2010), who extensively evaluated the BW treatment using UASB technology, observed similar treatment performance.

Table 2.1 Key performance parameters of black water (BW) anaerobic treatment. Mean total and soluble OLR, total and suspended COD removal rates, methanization, level of hydrolysis of solids and SRT were calculated for the operational period between days 55 and 260 .

\begin{tabular}{llll}
\hline Operation time & days & 260 & \\
HRT & days & 7.8 & \pm 0.6 \\
Solids loading & $\mathrm{gTSS} \mathrm{d}^{-1}$ & 2.5 & \pm 1.6 \\
OLR & $\mathrm{kgCOD} \mathrm{m}^{-3} \mathrm{~d}^{-1}$ & 1.0 & \pm 0.3 \\
OLRsoluble & $\mathrm{kgCOD} \mathrm{m}^{-3} \mathrm{~d}^{-1}$ & 0.4 & \pm 0.2 \\
COD $_{\text {Total removal }}$ & & $87 \%$ & $\pm 4 \%$ \\
COD & & $92 \%$ & $\pm 4 \%$ \\
Methanization & & 0.65 & \pm 0.26 \\
Level of hydrolysis of solids & $\mathrm{mgCOD} \mathrm{CH}_{4} \mathrm{mg}^{-1} \mathrm{COD}-\mathrm{BW}$ & 0.65 & \pm 0.34 \\
SRT & & 316 & \\
\hline
\end{tabular}




\subsubsection{Effect of soluble $\mathrm{Ca}^{2+}$ and $\mathrm{HCO}_{3}{ }^{-}$fluctuations in black water on $\mathrm{PO}_{4}{ }^{3-}$ removal}

During 260 days of operation, a wide concentration range was observed for $\mathrm{HCO}_{3}{ }^{-}$ and $\mathrm{Ca}^{2+}$ in raw $\mathrm{BW}$, affecting the accumulation of $\mathrm{P}$ in the UASB reactor. According to Figure 2.1, an increase of $\mathrm{HCO}_{3}{ }^{-}$in $\mathrm{BW}$ from $1.2 \pm 0.2$ to $2.7 \pm 0.3 \mathrm{~g} \mathrm{~L}^{-1}$ is associated with a decrease of soluble $\mathrm{Ca}^{2+}$ from $54 \pm 9$ to $39 \pm 8 \mathrm{mg} \mathrm{L}^{-1}$ and an increase in $\mathrm{pH}$ from $7.59 \pm 0.17$ to $8.28 \pm 0.24$. This resulted in a reduction of $\mathrm{PO}_{4}{ }^{3-}$ removal during the $\mathrm{BW}$ treatment from 15 to $-47 \%$, due to hydrolysis of organically bound $\mathrm{P}$ and/or release of $\mathrm{PO}_{4}{ }^{3-}$ from already formed $\mathrm{Ca}_{\mathrm{x}}\left(\mathrm{PO}_{4}\right)_{\mathrm{y}}$. This is because $\mathrm{HCO}_{3}{ }^{-}$competes with $\mathrm{PO}_{4}{ }^{3-}$ for $\mathrm{Ca}^{2+}$ ions to precipitate as calcium carbonate $\left(\mathrm{CaCO}_{3}\right)$ (Cao and Harris, 2008). According to geochemical modelling, the aforementioned change in $\mathrm{HCO}_{3}{ }^{-}, \mathrm{Ca}^{2+}$, and $\mathrm{pH}$ triggers supersaturation for $\mathrm{CaCO}_{3}$ phases, such as calcite (SI from 0.6 to 3 ) and dolomite (SI from 0.1 to 3.2), while it reduces the saturation stated of $\mathrm{Ca}_{\mathrm{x}}\left(\mathrm{PO}_{4}\right)_{\mathrm{y}}$ phases. For instance the SI of amorphous calcium phosphate (ACP) and octacalcium phosphate $(\mathrm{OCP})$, which are precursors of more stable $\mathrm{Ca}_{\mathrm{x}}\left(\mathrm{PO}_{4}\right)_{\mathrm{y}}$ phases (Habraken et al., 2013), decreases from 1.4 to 1.3 and from 1.8 to 0.5 , respectively. Thus, most likely the increase in $\mathrm{HCO}_{3}^{-}$limits $\mathrm{Ca}_{\mathrm{x}}\left(\mathrm{PO}_{4}\right)_{\mathrm{y}}$ precipitation by decreasing the ion activity of $\mathrm{Ca}^{2+}$.

More than $80 \%$ of the $\mathrm{Mg}$ in BW was already in the solid form (not shown). Moreover, accumulation of $\mathrm{Mg}$ (mainly as struvite) was observed in the sludge bed, inlet tube, and top settler of the UASB reactor. Thus, the presence of $\mathrm{Mg}$ can contribute to the $\mathrm{P}$ accumulation in the form of struvite. However, the $\mathrm{Mg}^{2+}$ (soluble) in BW $\left(14 \pm 9 \mathrm{mg} \mathrm{L}^{-1}\right)$ does not have a significant influence on $\mathrm{PO}_{4}{ }^{3-}$ removal compared to $\mathrm{Ca}^{2+}$. Mono-cations, such as $\mathrm{Na}^{+}$and $\mathrm{K}^{+}\left(343 \pm 70\right.$ and $232 \pm 47 \mathrm{mg} \mathrm{L}^{-1}$, respectively) do not significantly change during the operation period nor influence $\mathrm{P}$ accumulation.

In this study and in Tervahauta et al. (2014c), the accumulation of P in the UASB reactor (56 and $51 \%$, respectively) was higher than the previously reported by Graaff et al. (2010) (39\%), all under similar operational conditions in the UASB reactor. The change in $P$ accumulation is likely due to changes in $\mathrm{Ca}^{2+}$ and $\mathrm{HCO}_{3}{ }^{-}$concentrations in $\mathrm{BW}$ which can be a result of dilution during $\mathrm{BW}$ collection and variations during softening of drinking water (Graaff et al., 2010; Mulder et al., 2014). According to Table 2.2, the concentration of $\mathrm{HCO}_{3}$ in BW was significantly lower in this study and in Tervahauta et al. (2014c) compared to the previous study of Graaff et al. (2010), while the concentration of $\mathrm{Ca}^{2+}$ increased, as well as the accumulation of $\mathrm{P}$ during the BW treatment. The higher $\mathrm{Ca}^{2+}$ in Tervahauta et al. (2014c) is perhaps due to the lower average $\mathrm{PO}_{4}{ }^{3-}$ concentration compared to this study (Table 2.2), increasing the free $\mathrm{Ca}^{2+}$ which would otherwise form $\mathrm{Ca}_{x}\left(\mathrm{PO}_{4}\right)_{y}$. 
Moreover, Moerman et al. (2009), who investigated the effect of $\mathrm{Ca}^{2+}$ on the recovery of struvite from effluent of UASB reactor treating potato processing wastewater, observe that besides the $\mathrm{Ca}^{2+} / \mathrm{PO}_{4}{ }^{3-}$ molar ratio above 1 , also an increase in $\mathrm{Ca}^{2+}$ concentration e.g. from 40 to $65 \mathrm{mg} \mathrm{L}^{-1}$ decreased significantly the $\mathrm{P}$ recovery as struvite due to formation of $\mathrm{Ca}_{\mathrm{x}}\left(\mathrm{PO}_{4}\right)_{\mathrm{y}}$; although the $\mathrm{Ca}^{2+} / \mathrm{PO}_{4}{ }^{3-}$ was 0.4 . This supports the importance of ionic activity of $\mathrm{Ca}^{2+}$ for $\mathrm{PO}_{4}{ }^{3-}$ removal as observed in this study. In a full scale UASB reactor treating municipal wastewater (Minas Gerais, Brasil), a negative correlation between $\mathrm{PO}_{4}{ }^{3-}$ removal and alkalinity (as $\mathrm{CaCO}_{3}$ ) was found and, on average, $\mathrm{PO}_{4}{ }^{3-}$ concentration increased during the treatment (Barbosa Correa et al., 2003). Also during treatment of filtered pig manure in an UASB reactor, $\mathrm{PO}_{4}{ }^{3-}$ removal increased from 32 to $81 \%$ while influent $\mathrm{pH}$ decreased from 6.9 to 5.2 (Kalyuzhnyi et al., 2002). Similar profile was observed in this study (Figure 2.1). Suggesting that influent composition and treatment conditions play an important role in the fate of $\mathrm{PO}_{4}{ }^{3-}$.

Due to the lower $\mathrm{HCO}_{3}{ }^{-}$concentration and consequent increase in $\mathrm{Ca}^{2+}$ during this study and in Tervahauta et al. (2014c), $\mathrm{Ca}_{\mathrm{x}}\left(\mathrm{PO}_{4}\right)_{\mathrm{y}}$ precipitation was favoured. Then, accumulation of $\mathrm{Ca}_{\mathrm{x}}\left(\mathrm{PO}_{4}\right)_{\mathrm{y}}$ particles likely triggered $\mathrm{CaP}$ granulation by acting as nucleus for granule formation. Hulshoff Pol et al. (2004), who reviewed the effect of inert particles in granulation, observed that the presence of these particles accelerates granulation by giving surface for microbial attachment. This promotes the development of an outer biofilm around the seed particle, providing advantage for syntrophic relationships between microorganisms which are crucial for degradation of complex carbohydrate substrates to $\mathrm{CH}_{4}$ and $\mathrm{CO}_{2}$ (Wirtz and Dague, 1996). Thus, the higher $P$ accumulation in the UASB reactor most likely promoted CaP granulation as observed in this study and in Tervahauta et al. (2014c), due to the higher $\mathrm{Ca}^{2+}$ and lower $\mathrm{HCO}_{3}{ }^{-}$concentrations. 


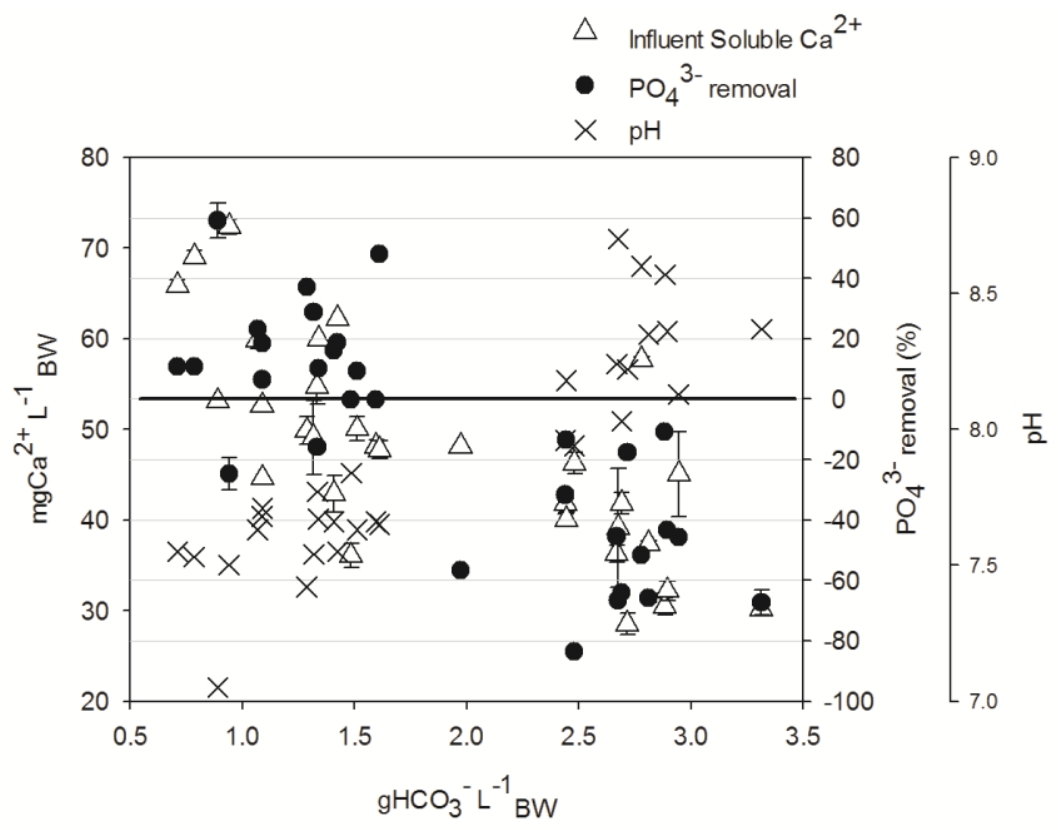

Figure 2.1 Correlation between $\mathrm{Ca}^{2+}, \mathrm{HCO}_{3}{ }^{-}$, and $\mathrm{pH}$ in the influent (black water) and $\mathrm{PO}_{4}{ }^{3-}$ removal, during the monitoring period (260 days). Negative $\mathrm{PO}_{4}{ }^{3-}$ removal is due to hydrolysis of organically bound $\mathrm{P}$ and dissolution of $\mathrm{P}$ precipitates.

Table 2.2 Comparative summary of $\mathrm{HCO}_{3}{ }^{-}, \mathrm{Ca}^{2+}$, and $\mathrm{PO}_{4}{ }^{3-}$ concentrations and $\mathrm{pH}$ in $\mathrm{BW}$ during this and previous studies on anaerobic treatment of $\mathrm{BW}$.

\begin{tabular}{|c|c|c|c|c|c|c|c|c|}
\hline & $\mathrm{HCO}_{3}^{-}$ & & $\mathrm{Ca}^{2+}$ & & $\mathrm{PO}_{4}{ }^{3-}-\mathrm{P}$ & & $\mathrm{pH}$ & \\
\hline & $\mathrm{g} \mathrm{L}^{-1}$ & s.d. & $\mathrm{mg} \mathrm{L}^{-1}$ & s.d. & $\mathrm{mg} \mathrm{L}^{-1}$ & s.d. & & s.d. \\
\hline This study & 1.9 & \pm 0.8 & 48 & \pm 11 & 55 & \pm 20 & 7.9 & \pm 0.4 \\
\hline (Tervahauta et al., 2014c) & 3.6 & \pm 1.1 & 62 & \pm 7 & 49 & \pm 9 & 8.1 & n.a. \\
\hline (Graaff et al., 2010) & 5.6 & \pm 2.8 & 39 & \pm 18 & 67 & \pm 17 & 8.7 & \pm 0.75 \\
\hline
\end{tabular}

\subsubsection{Phosphorus mass balance and sludge bed development}

Of the total amount of $\mathrm{P}$ fed, 44\% was found in the effluent (Figure 2.2a), indicating that $56 \%$ accumulated in the reactor. Average soluble $\mathrm{P}$ in the influent (BW) and effluent was $56.9 \pm 12.3$ and $59.5 \pm 6.9 \mathrm{mgP} \mathrm{L}^{-1}$, respectively. Particulate $\mathrm{P}$ in $\mathrm{BW}\left(134 \pm 83 \mathrm{mgP} \mathrm{L}^{-1}\right)$, which represented $67 \pm 11 \%$ of the total $\mathrm{P}$, was mostly retained in the reactor. This is because the low upflow velocity $\left(0.4 \mathrm{~cm} \mathrm{~h}^{-1}\right)$ applied in the UASB reactor promoted accumulation of fine particulate $P$. 
The P mass balance is shown in Figure 2.2a. Approximately 5\% of the total P fed was as $\mathrm{CaP}$ granules in the reactor after 260 days of operation, but sampled granules were not included. The non-quantifiable $\mathrm{P}$ estimates the quantity of $\mathrm{P}$ accumulated at the bottom of the UASB reactor and inlet tube. According to EDX analysis, collected particles in the inlet tube were mainly $\mathrm{Ca}_{\mathrm{x}}\left(\mathrm{PO}_{4}\right)_{\mathrm{y}}$ and struvite precipitates with $\mathrm{P}$ content of approximately 13 and 21 wt $\%$ of dry matter, respectively. The P distribution in the sludge bed after 260 days was 26 , 25 , and $49 \%$ as $\mathrm{CaP}$ granules, smaller inorganic particles, and organic sludge, respectively. Over time the inorganic particles can grow into granules, but further research is needed to estimate the growth rate and conditions to favor granulation.

The development of suspended solids (TSS and VSS) and P, Ca, and Mg contents in the sludge bed, at $5 \mathrm{~cm}$ from the bottom of the UASB reactor, are shown in Figure 2.2b and Figure 2.2c, respectively. A total amount of 10 gTSS (2 L) with $76 \pm 6 \%$ VSS were inoculated ( $2 \mathrm{~L})$. The sludge bed height was maintained at $70 \%$ of the reactor volume (3.6 L). After 35 days of operation, the TSS concentration at $5 \mathrm{~cm}$ from the bottom of the reactor was on average $55 \pm 12 \mathrm{gTSS} \mathrm{kg}^{-1}$ of sludge with an organic content (VSS) of $72 \pm 6 \%$ (Figure 2.2b). On day 260 , the TSS concentration at $5,10,20$, and $30 \mathrm{~cm}$ high in the sludge bed was $60 \pm 9,46 \pm 6$, $37 \pm 7$, and $41 \pm 8 \mathrm{gTSS} \mathrm{kg}^{-1}$ of sludge, respectively. The P content of the sludge increased from $20 \pm 3 \mathrm{mg} \mathrm{g}^{-1}$ of TSS in the inoculum to $61 \pm 2 \mathrm{mg} \mathrm{g}^{-1}$ of TSS after 70 days (Figure 2.2c). A similar increase is observed for $\mathrm{Ca}$ and $\mathrm{Mg}$, suggesting accumulation of $\mathrm{Ca}$ and $\mathrm{Mg}$ phosphates. The accumulation of these precipitates in the sludge bed likely triggered $\mathrm{CaP}$ granulation, which was visible after 100 days of operation.
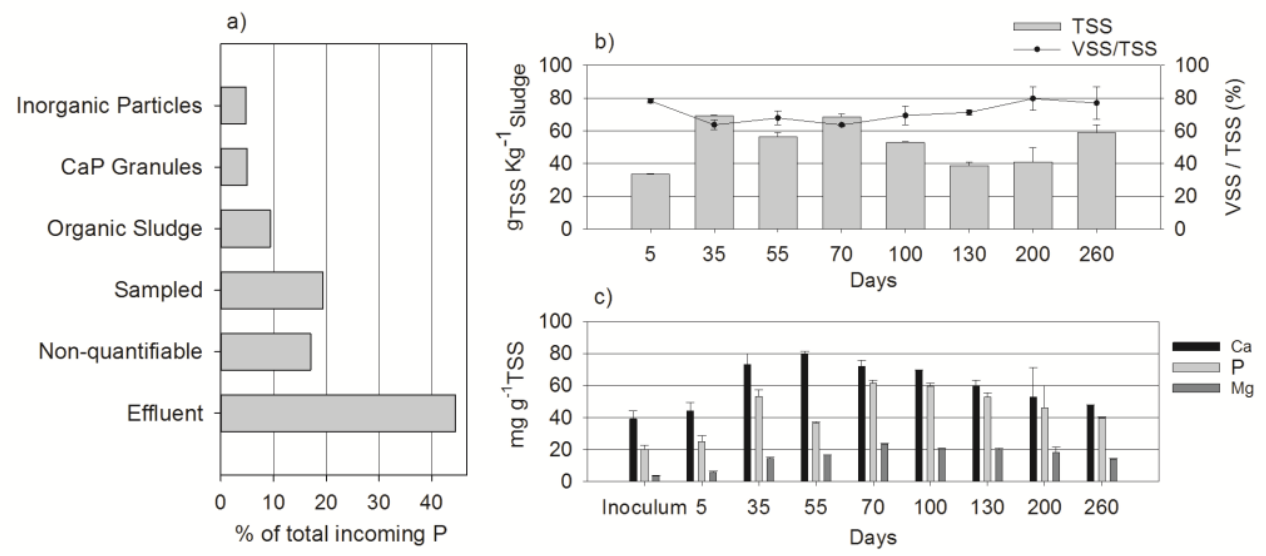

Figure 2.2 Phosphorus (P) mass balance for 260 days of continuous operation of BW treatment in the UASB reactor, assuming the organic $\mathrm{P}$ content of organic sludge as $26 \mathrm{mg} \mathrm{g}^{-1}$ of volatile suspended solids (VSS) (a). Concentration of total suspended solids (TSS) and respective percentage of VSS (b) and $\mathrm{P}, \mathrm{Ca}$, and $\mathrm{Mg}$ contents (c) at $5 \mathrm{~cm}$ from the bottom of the reactor over time. A total amount of $10 \mathrm{gTSS}(76 \pm 6 \% \mathrm{VSS})$ were inoculated $(2 \mathrm{~L})$. 


\subsubsection{Granule formation and characterization}

A gradual formation of granules was observed approximately after 100 days at the lower part of the sludge bed (Figure 2.3a). A backscattered SEM representation of a representative cut $\mathrm{CaP}$ granule from a sample taken at $5 \mathrm{~cm}$ from the bottom of the reactor is shown in Figure 2.3b. The inorganic rich core (whitish) is surrounded by an organic outer layer (dark gray). According to the EDX analysis on the sampled granule, $\mathrm{P}$ and $\mathrm{Ca}$ were the dominant elements in the centre (Figure 2.3c). Moreover, XRD analysis on CaP granules (results not shown) showed that hydroxyapatite (HAP) and carbonated HAP are the dominant crystal phases. Similar results were obtained by Tervahauta et al. (2014c). This confirms the presence of $\mathrm{Ca}_{\mathrm{x}}\left(\mathrm{PO}_{4}\right)_{\mathrm{y}}$ in the core of the granules and supports the hypothesis that accumulation of $\mathrm{Ca}_{\mathrm{x}}\left(\mathrm{PO}_{4}\right)_{\mathrm{y}}$ particles trigger $\mathrm{CaP}$ granulation by giving surface for microbial attachment as aforementioned. Visualization of $\mathrm{Mg}$ containing precipitates was also possible, but with lower intensity compared to $\mathrm{Ca}$ based precipitates. The $\mathrm{P}, \mathrm{Ca}$, and $\mathrm{Mg}$ contents of the densest fraction in the separation column (CaP granules) were $61 \pm 8,81 \pm 15$, and $19 \pm 2 \mathrm{mg} \mathrm{g}^{-1}$ of TSS, respectively. Moreover, the ash content of this fraction was $35 \pm 6 \%$. The $\mathrm{P}$ content observed in the $\mathrm{CaP}$ granules is high compared to other types of anaerobic granular sludge, ranging from 16 (generally assumed as common biological assimilation of $\mathrm{P}$ ) up to $36 \mathrm{mgP} \mathrm{g}^{-1}$ of TSS (D’Abzac et al., 2010; Langerak et al., 1998; Yu et al., 2001). The P enrichment in the reviewed anaerobic granular sludge was associated with co-precipitation of $\mathrm{Ca}_{\mathrm{x}}\left(\mathrm{PO}_{4}\right)_{\mathrm{y}}$ with $\mathrm{CaCO}_{3}$, due to the high concentration of $\mathrm{Ca}^{2+}$ (> $400 \mathrm{mg} \mathrm{L}^{-1}$ ) in the liquid phase (Langerak et al., 1998; $\mathrm{Yu}$ et al., 2001).

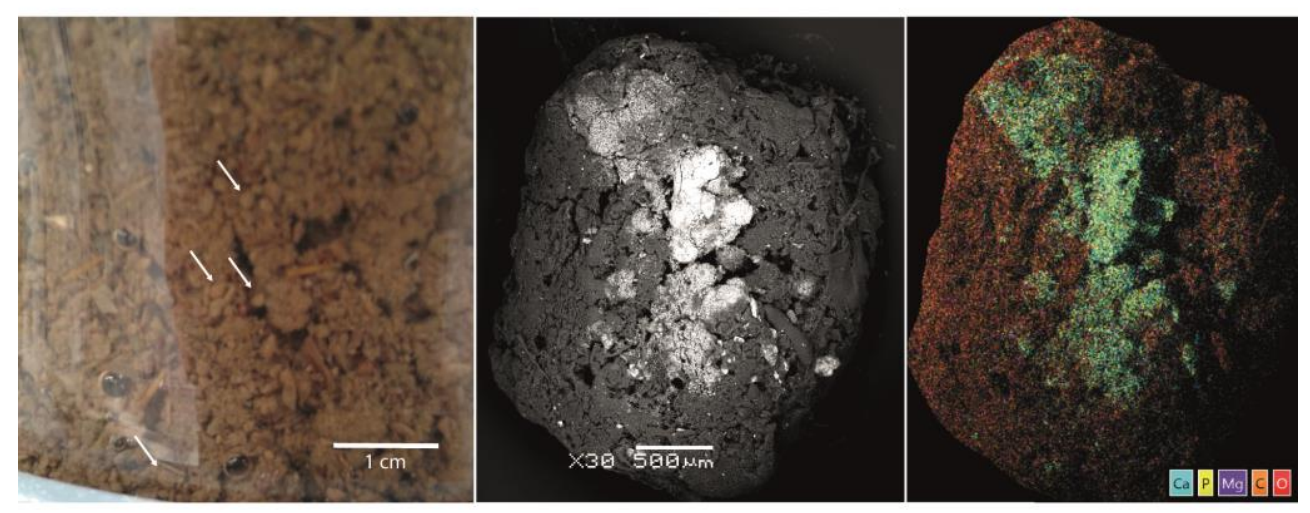

Figure 2.3 Image of the sludge bed on day 93 (a), corresponding to the start of granulation. Arrows indicate calcium phosphate $(\mathrm{CaP})$ granules in the sludge bed. Image of a representative $\mathrm{CaP}$ granule cross-section acquired with backscattered scanning electron microscope (b), and the respective elemental distribution obtained with energy dispersive X-ray analysis (c). 


\subsubsection{Higher $P$ accumulation by adding $\mathrm{Ca}^{2+}$}

Relatively high concentration of soluble $\mathrm{P}\left(59.5 \pm 6.9 \mathrm{mg} \mathrm{PO}{ }^{3-}-\mathrm{P} \mathrm{L}^{-1}\right.$, representing approximately $31 \%$ of the total $\mathrm{P}$ in $\mathrm{BW}$ ) is present in the UASB reactor effluent, although $\mathrm{Ca}^{2+}\left(33 \pm 5.9 \mathrm{mg} \mathrm{L}^{-1}\right)$ is still available. But, $\mathrm{Ca}_{\mathrm{x}}\left(\mathrm{PO}_{4}\right)_{\mathrm{y}}$ precursors, such as ACP and OCP (Habraken et al., 2013), are under saturated in the effluent of the UASB reactor (SI $=0.17$ and $\mathrm{SI}=0.02$, respectively), therefore, $\mathrm{Ca}_{\mathrm{x}}\left(\mathrm{PO}_{4}\right)_{\mathrm{y}}$ precipitation hardly occurs in the effluent. Additionally, the total $\mathrm{Ca} / \mathrm{P}$ molar ratio in $\mathrm{BW}$ is only 0.65 , indicating that $\mathrm{Ca}^{2+}$ limits $\mathrm{Ca}_{\mathrm{x}}\left(\mathrm{PO}_{4}\right)_{\mathrm{y}}$ precipitation. This is because $\mathrm{Ca}_{\mathrm{x}}\left(\mathrm{PO}_{4}\right)_{\mathrm{y}}$ phases, such as $\mathrm{ACP}$, octacalcium phosphate (OCP) and HAP have a higher theoretical $\mathrm{Ca} / \mathrm{P}$ molar ratio, varying from 1.35 to 1.67 (Habraken et al., 2013).

Therefore, preliminary tests were performed to investigate the effect of adding $\mathrm{Ca}^{2+}$ in treated BW (Figure 2.4). $\mathrm{P}$ precipitation was observed for $\mathrm{Ca}^{2+} / \mathrm{PO}_{4}{ }^{3-}$ molar ratios of 3 and 4.8. For instance, at $\mathrm{Ca}^{2+} / \mathrm{PO}_{4}{ }^{3-}$ molar ratio of 3 the concentration of $\mathrm{PO}_{4}{ }^{3-}$ decreased $63 \%$ in 12 days, yet co-precipitation of $\mathrm{CaCO}_{3}$ was observed (approximately $36 \%$ of the $\mathrm{Ca}^{2+}$ precipitated as $\mathrm{CaCO}_{3}$ ). The absence of $\mathrm{P}$ precipitation at $\mathrm{Ca}^{2+} / \mathrm{PO}_{4}{ }^{3-}$ molar ratio of 1.5 can be explained by $\mathrm{HCO}_{3}{ }^{-}$inhibition and presence of soluble humic substances in treated BW $(89 \pm$ $34 \mathrm{mgC} \mathrm{L}^{-1}$ ). This is because humic substances decrease the activity of both $\mathrm{Ca}^{2+}$ and $\mathrm{PO}_{4}{ }^{3-}$ by complexation (Song et al., 2006a). Because the effluent collection in the recirculation columns was not completely gas-tight, both $\mathrm{HCO}_{3}{ }^{-}$and $\mathrm{pH}$ decreased in all columns due to equilibration with atmospheric $\mathrm{CO}_{2}$ and $\mathrm{H}^{+}$release from $\mathrm{HPO}_{4}{ }^{2-}$ caused by precipitation.
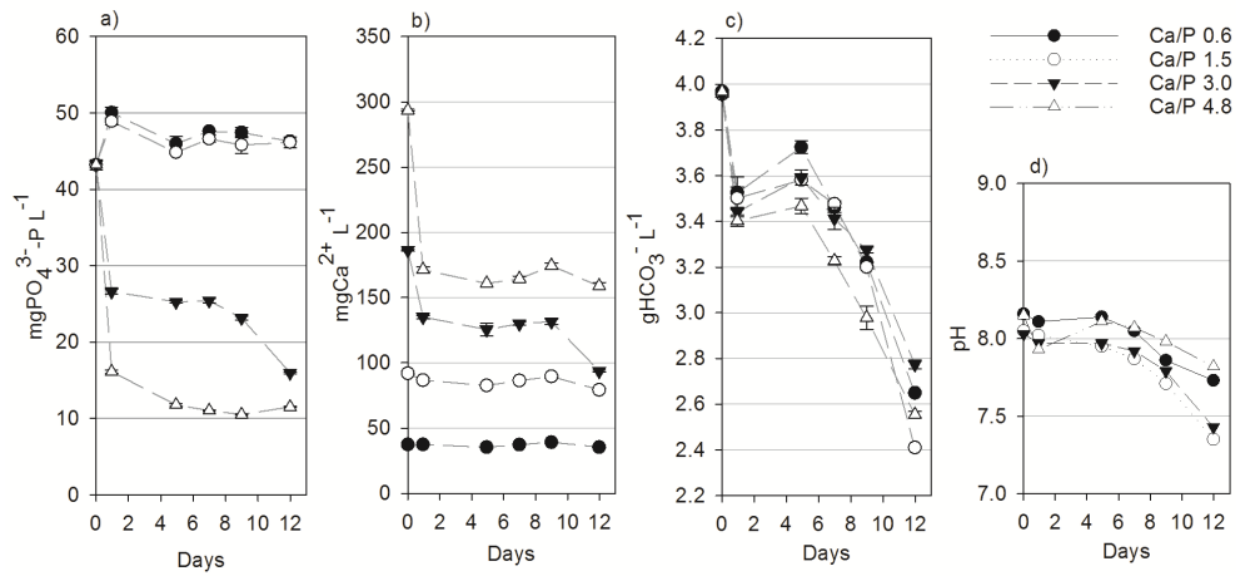

Figure 2.4 Concentration of $\mathrm{PO}_{4}{ }^{3-}(\mathrm{a}), \mathrm{Ca}^{2+}(\mathrm{b}), \mathrm{HCO}_{3}{ }^{-}(\mathrm{c})$, and $\mathrm{pH}(\mathrm{d})$ in treated black water, over a period of 12 days in $1 \mathrm{~L}$ recirculation columns, for different $\mathrm{Ca}^{2+} / \mathrm{PO}_{4}{ }^{3-}$ molar ratios: 0.6 (no $\mathrm{Ca}^{2+}$ addition), 1.5, 3.0 and 4.8. 


\subsubsection{Combining the recovery of calcium phosphate granules and methane in a single reactor}

$\mathrm{CaP}$ granules produced from BW have lower heavy metal content than domestic sewage sludge ash (SSA) and BioP sludge ash (Tervahauta et al., 2014c). For instance, faeces represents only $10 \%$ of the total concentration of heavy metals in combined sewage, and they are from human excretion (Tervahauta et al., 2014b). Moreover, the heavy metal content and concentration of radioactive compounds in rock phosphate largely depend on the location of extraction and ore type (Aydin et al., 2010). On top of that, the worsening quality and depletion of rock phosphate threat its use, resulting in reduction of commercial ore deposits (Koppelaar and Weikard, 2013). Therefore, recovered products from BW, such as $\mathrm{CaP}$ granules and struvite, are cleaner and safer substitutes for rock phosphate. However, risks with other potential micropollutants and resistant bacterial genes need further investigation, especially in CaP granules due to the residual organic content (Butkovskyi et al., 2016; Graaff et al., 2011c).

The recovery of $\mathrm{P}$ from BW as struvite is limited by the accumulation of $\mathrm{Ca}_{\mathrm{x}}\left(\mathrm{PO}_{4}\right)_{\mathrm{y}}$ in the reactor. Moreover, for locations with higher hardness levels in water used for toilet flushing compared to Dutch averages (0.7-2.1 $\mathrm{mmolCa}^{2+}$ and/or $\mathrm{Mg}^{2+} \mathrm{L}^{-1}$ ) (Mulder et al., 2014), the accumulation of $P$ in the reactor would increase further due to the increase of $\mathrm{Ca}^{2+}$. According to Figure 2.4, by adding $300 \mathrm{mgCa}^{2+} \mathrm{L}^{-1}\left(\mathrm{Ca}^{2+} / \mathrm{PO}_{4}{ }^{3-}\right.$ molar ratio of 3$)$ in the effluent of the UASB reactor, $63 \%$ of the $\mathrm{PO}_{4}{ }^{3-}$ precipitated. When extrapolated, the accumulation of total $\mathrm{P}$ from $\mathrm{BW}$ would increase to more than $85 \%$ by adding $\mathrm{Ca}^{2+}$ directly in the UASB reactor. This would also increase the formation of seed particles in the reactor, and consequently, enhance $\mathrm{CaP}$ granulation as aforementioned. Thus, recovery of $\mathrm{P}$ as $\mathrm{CaP}$ granules during the anaerobic treatment of BW could potentially lead to higher P recovery efficiency compared with the current applied process of struvite precipitation. Yet, addition of $\mathrm{Ca}^{2+}$ directly in the UASB reactor will need to be tested further to estimate the optimal $\mathrm{Ca}^{2+}$ loading rate for $\mathrm{CaP}$ granulation. Simultaneously, COD removal and methanization rate should be maintained at the required levels. Therefore, ongoing research is focusing on the formation and growth rate of $\mathrm{CaP}$ granules, and on the process hydrodynamics for selective separation and harvesting of $\mathrm{CaP}$ granules. 


\subsection{Conclusions}

$\mathrm{P}$ accumulation in the UASB reactor (56\% in this study) is dependent on the $\mathrm{HCO}_{3}$ and $\mathrm{Ca}^{2+}$ concentrations in the influent $\mathrm{BW}$. When $\mathrm{HCO}_{3}{ }^{-}$was below $2 \mathrm{~g} \mathrm{~L}^{-1}$, the average $\mathrm{Ca}^{2+}$ was $54 \mathrm{mg} \mathrm{L}^{-1}$ and $\mathrm{PO}_{4}{ }^{3-}$ (soluble) decreased during $\mathrm{BW}$ treatment, due to $\mathrm{Ca}_{\mathrm{x}}\left(\mathrm{PO}_{4}\right)_{\mathrm{y}}$ precipitation in the reactor. However, for $\mathrm{HCO}_{3}{ }^{-}$values above $2 \mathrm{~g} \mathrm{~L}^{-1}$, the average $\mathrm{Ca}^{2+}$ was 39 $\mathrm{mg} \mathrm{L} \mathrm{L}^{-1}$ and the concentration of $\mathrm{PO}_{4}{ }^{3-}$ increased during the treatment. This is because organically bound $\mathrm{P}$ was hydrolysed during the treatment, releasing $\mathrm{PO}_{4}^{3-}$, and $\mathrm{HCO}_{3}$ decreased the ion activity of $\mathrm{Ca}^{2+}$, reducing $\mathrm{Ca}_{x}\left(\mathrm{PO}_{4}\right)_{y}$ precipitation and consequently, accumulation of $\mathrm{P}$ in the reactor. $\mathrm{CaP}$ granulation was observed after 100 days of operation. $63 \%$ of the $\mathrm{PO}_{4}{ }^{3-}$ in treated $\mathrm{BW}$ precipitated by adding $\mathrm{Ca}^{2+}$ to a $\mathrm{Ca}^{2+} / \mathrm{PO}_{4}{ }^{3-}$ molar ratio of 3 . When extrapolated, addition of $\mathrm{Ca}^{2+}$ directly in the UASB reactor can potentially increase the $\mathrm{P}$ accumulation to more than $85 \%$ and consequently, enhance $\mathrm{CaP}$ granulation by increasing the surface for microbial attachment due to the higher formation of seed particles. 
Chapter 3. Calcium addition to increase the production of phosphate granules in anaerobic treatment of black water

J. R. Cunha, C. Schott, R. D. van der Weijden, L. Hernández Leal, G. Zeeman, C. J. N. Buisman

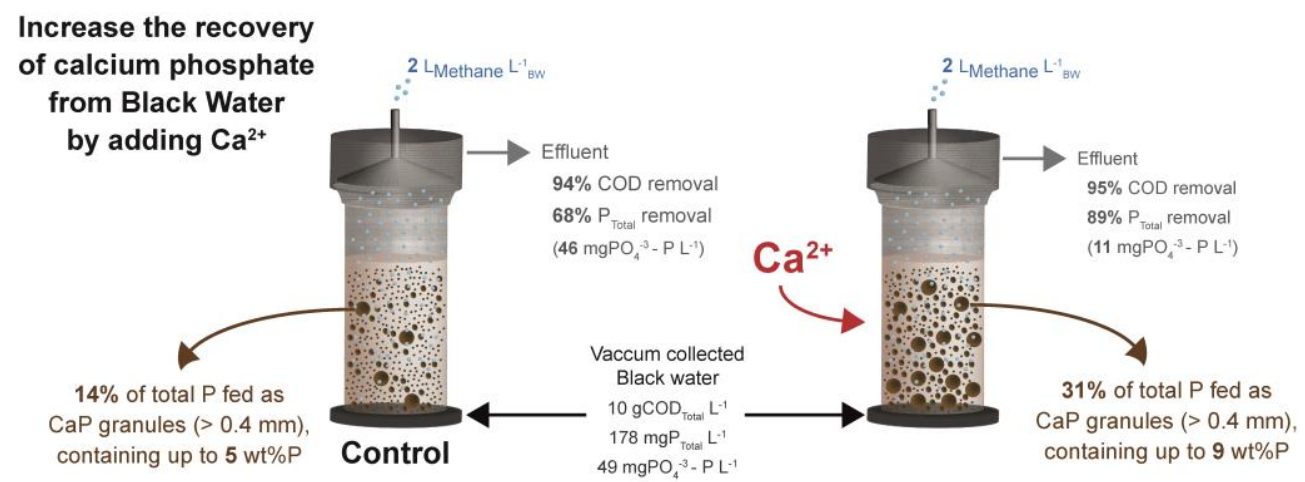

This chapter was published as:

J. R. Cunha, C. Schott, R. D. van der Weijden, L. Hernández Leal, G. Zeeman, C. J. N. Buisman, 2018. Calcium addition to increase the production of phosphate granules in anaerobic treatment of black water. Water Research. 130. $333-342$. 


\begin{abstract}
Simultaneous recovery of calcium phosphate granules (CaP granules) and methane from vacuum collected black water (BW), using an upflow anaerobic sludge blanket (UASB) reactor was previously investigated. It was calculated that only $2 \%$ of the total phosphorus $(\mathrm{P})$ fed was present as $\mathrm{CaP}$ granules whereas $51 \%$ of the $\mathrm{P}$ accumulated dispersed in the reactor, limiting the applicability of this process for recovery of phosphate. This study proposes adding calcium to increase the $\mathrm{P}$ accumulation in the reactor and the production of $\mathrm{CaP}$ granules. Calcium was added in a lab-scale UASB reactor fed with BW. An identical UASB reactor was used as reference, to which no calcium was added. The treatment performance was evaluated by weekly monitoring of influent, effluent, and produced biogas. Sludge bed development and $\mathrm{CaP}$ granulation were assessed through particle size analysis. The composition and structure of $\mathrm{CaP}$ granules were chemically and optically assessed. Calcium addition increased accumulation of $\mathrm{P}$ in the reactor and formation and growth of granules with size $>0.4 \mathrm{~mm}$ diameter (CaP granules). Moreover, with calcium addition, $\mathrm{CaP}$ granules contained $5.6 \pm 1.5$ wt $\%$ P, while without calcium a lower $\mathrm{P}$ content was observed $(3.7 \pm 0.3 \mathrm{wt} \%)$. By adding $\mathrm{Ca}$, $89 \%$ of the incoming $\mathrm{P}$ from BW accumulated in the reactor and $31 \%$ was sampled as $\mathrm{CaP}$ granules (> $0.4 \mathrm{~mm}$ diameter). Addition of $250 \mathrm{mgCa} \mathrm{L}^{-1}$ of $\mathrm{BW}$ was the optimum loading found in this study. Furthermore, no significant reduction in $\mathrm{COD}_{\text {Total }}$ removal $(>80 \%)$ and $\mathrm{CH}_{4}$ production $\left(0.47 \pm 0.10\right.$ gCOD- $\mathrm{CH}_{4} \mathrm{~g}^{-1}$ of $\mathrm{COD}_{\text {Total }}$ in $\left.\mathrm{BW}\right)$ was observed. Therefore, adding calcium can significantly increase the $\mathrm{CaP}$ granulation without inhibiting the simultaneous $\mathrm{CH}_{4}$ recovery. This further indicates the potential of this process for phosphate recovery.
\end{abstract}




\subsection{Introduction}

Recovery of phosphate from wastewater is crucial for the sustainable use of resources (Cordell et al., 2011). European regulation requires removal of phosphorus (P) from wastewater (Schröder et al., 2010), due to the severe environmental impact of P discharge in natural water courses (Jarvie et al., 2006). On the other hand, the processing and extraction costs of natural phosphate rock ( $\mathrm{P}$ rock), which is the present main source of $\mathrm{P}$, are significantly increasing due to the decrease in ore quality and its geographic distribution (Aydin et al., 2010; Koppelaar and Weikard, 2013). Thus, the need to remove $\mathrm{P}$ from wastewater and the increasing concerns about the future availability of $\mathrm{P}$, have lead many researchers to focus on developing processes to recover phosphate from wastewater streams.

By vacuum collection of source separated black water (BW), which uses $1 \mathrm{~L}$ of water per toilet flush, concentrations of total $\mathrm{P}$ ranging from 0.15 up to $0.22 \mathrm{gP} \mathrm{L}^{-1}$ of $\mathrm{BW}$ are obtained (Graaff et al., 2011a). Measurements show that in the Netherlands up to $480 \mathrm{gP}$ person $^{-1}$ year $^{-1}$ could potentially be recovered, considering a BW production of $6 \mathrm{~L}_{\text {person }}{ }^{-1}$ day $^{-1}$ (Kujawa-Roeleveld and Zeeman, 2006; Tervahauta et al., 2013). If this number is extrapolated for the global population, the phosphate recovery from BW would represent up to $14 \%$ of the current global demand of phosphate as P rock (Cooper et al., 2011; U.S. Geological Survey, 2015). The anaerobic treatment of BW using an upflow anaerobic sludge blanket (UASB) reactor has been tested at full scale since 2006 in Sneek (the Netherlands) (Graaf and Hell, 2014). At $25^{\circ} \mathrm{C}$ and hydraulic retention time (HRT) of 8 days, $54 \%$ of the chemical oxygen demand (COD) in BW is effectively converted into $\mathrm{CH}_{4}$ and $61 \%$ of the total incoming $\mathrm{P}$ leaves the reactor in the effluent mostly as soluble phosphate $\left(\mathrm{PO}_{4}{ }^{3-}\right)$ (Graaff et al., 2010).

A new process for simultaneous recovery of calcium phosphate granules $(\mathrm{CaP}$ granules) and methane $\left(\mathrm{CH}_{4}\right)$ in a UASB reactor treating BW was proposed by Tervahauta et al. (2014c). This proposal was based on observed calcium phosphate granulation (CaP granulation) which started after an increase in soluble calcium $\left(\mathrm{Ca}^{2+}\right)$ in $\mathrm{BW}$, triggering the formation of seed particles that served as initial nuclei for microbial colonization and calcium phosphate $\left(\mathrm{Ca}_{\mathrm{x}}\left(\mathrm{PO}_{4}\right)_{\mathrm{y}}\right)$ precipitation (Tervahauta et al., 2014c). As a result, the accumulation of $\mathrm{P}$ in the UASB reactor increased from 39 to 51\% (Graaff et al., 2011a; Tervahauta et al., 2014c). However, only $2 \%$ of the total incoming P from BW was present as CaP granules after 988 days (Tervahauta et al., 2014c), limiting the applicability of combined recovery of CaP granules and $\mathrm{CH}_{4}$ from BW. 
Previous research has shown that $\mathrm{Ca}^{2+}$ addition in the effluent of a UASB reactor treating BW increased P precipitation (Cunha et al., 2017). Therefore, this study proposes adding $\mathrm{Ca}^{2+}$ directly in the UASB reactor to increase both the accumulation of $\mathrm{P}$ in the reactor and the production of $\mathrm{CaP}$ granules, without significantly affecting the conversion of $\mathrm{COD}$ into $\mathrm{CH}_{4}$. This was experimentally investigated by running two identical lab scale UASB reactors fed with $\mathrm{BW}$ under similar operational conditions, except for the $\mathrm{Ca}^{2+}$ loading.

\subsection{Materials and Methods}

\subsubsection{Experimental set-up}

The experimental setup consisted of two identical glass UASB reactors $(5.1 \mathrm{~L})$ fed with BW as shown in Figure 3.1. BW was collected from a neighborhood equipped with vacuum toilets in Sneek (the Netherlands) and stored at $7^{\circ} \mathrm{C}$ prior use (Graaff et al., 2010). The inoculum (2 L) was taken from the UASB reactor described in Graaf and Hell (2014) and sieved before inoculation to remove particles larger $>0.4 \mathrm{~mm}$ diameter. Both reactors were operated for 460 days. Reactor R1 served as a control, while reactor R2 was dosed with $\mathrm{CaCl}_{2} \cdot 2 \mathrm{H}_{2} \mathrm{O}$ to test the influence of $\mathrm{Ca}^{2+}$ addition $\mathrm{P}$ accumulation and extent of $\mathrm{CaP}$ granulation. The overall operational period was divided in two phases. Phase 1 lasted from day 0 to 350 and it was considered as the start-up and adaptation period of the sludge inoculum. About once a month sludge was removed to keep the sludge bed volume approximately at $70 \%$ $(3.5 \mathrm{~L})$ of the total working volume of the reactor. During the first 150 days of phase 1 , the concentration of $\mathrm{Ca}^{2+}$ addition increased gradually every 50 days by steps of $100 \mathrm{mg} \mathrm{L}^{-1} \mathrm{BW}$ starting from $250 \mathrm{mg} \mathrm{L}^{-1} \mathrm{BW}$. After 150 days, the addition of $\mathrm{Ca}^{2+}$ decreased to $200 \mathrm{mg} \mathrm{L}^{-1} \mathrm{BW}$ until phase 2 (350 days), in order to decrease the saturation of $\mathrm{Ca}^{2+}$ in the reactor. Phase 2 lasted from day 350 to 460 . During phase 2, the dosed $\mathrm{Ca}^{2+}$ loading in $\mathrm{R} 2$ was gradually increased once more from $150 \mathrm{mg} \mathrm{L}^{-1} \mathrm{BW}$ on day 350 to $200,250,300$, and $400 \mathrm{mg} \mathrm{L}^{-1} \mathrm{BW}$ on day 370, 390, 420, and 440, respectively. Sludge bed sampling during phase 2 was performed on days $350,415,436$, and 460 , and the particle size distribution and elemental composition of each size fraction was measured to evaluate the formation and growth of $\mathrm{CaP}$ granules. Influent and effluent were continuously monitored, at least once a week, for: total and volatile suspended solids (TSS and VSS, respectively); total, colloidal, and soluble COD (COD Total, $\mathrm{COD}_{\text {Colloidal }}$ and $\mathrm{COD}_{\text {Soluble, }}$ respectively); total, organic, and inorganic carbon (TC, TOC and IC, respectively); volatile fatty acids (VFA); ammonium $\left(\mathrm{NH}_{4}^{+}\right)$; anions $\left(\mathrm{Cl}^{-}, \mathrm{NO}_{3}{ }^{-}, \mathrm{NO}_{2}{ }^{-}, \mathrm{SO}_{4}{ }^{2-}\right.$ and $\left.\mathrm{PO}_{4}{ }^{3-}\right)$ and total and soluble elements $(\mathrm{P}, \mathrm{Ca}, \mathrm{Mg}, \mathrm{K}$, and $\mathrm{Na}$ ). Biogas production and composition were monitored with the same frequency. 


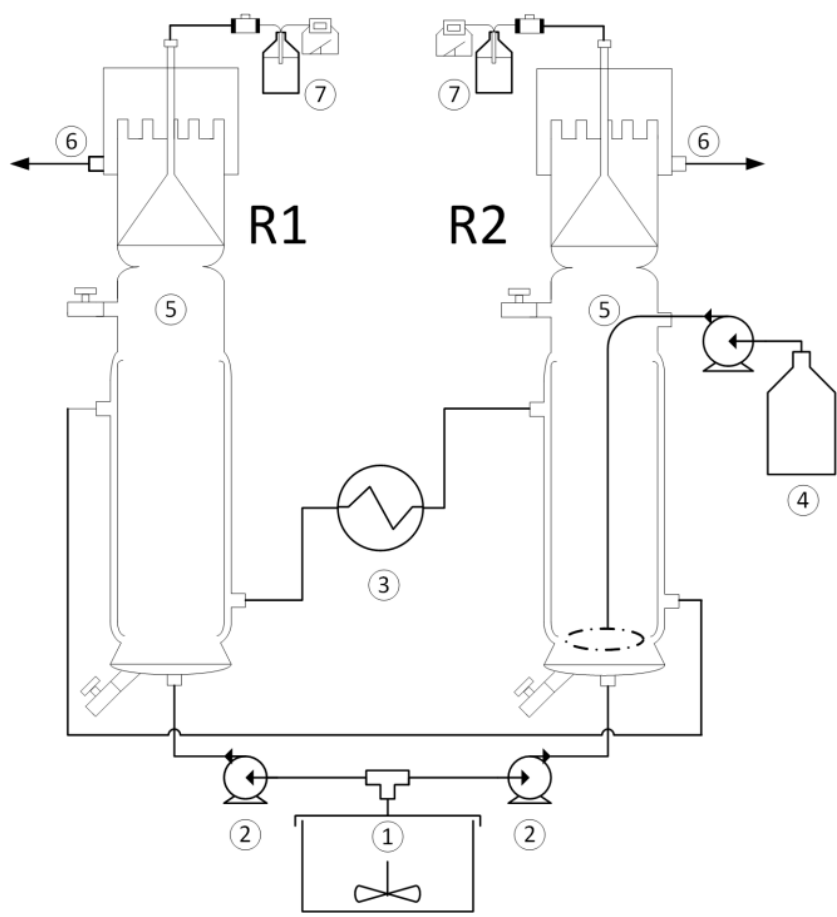

Figure 3.1 Scheme of experimental setup: (1) Storage tank of black water, cooled $\left(7^{\circ} \mathrm{C}\right)$ and stirred; (2) Feeding pumps (Masterflex L/S 77200-60); (3) Shared heating system (Thermo Scientific, DC10 KC10) for temperature control $\left(25^{\circ} \mathrm{C}\right)$; (4) $\mathrm{CaCl}_{2} \cdot 2 \mathrm{H}_{2} \mathrm{O}$ feeding system for reactor R2; (5) UASB reactors $(5.1 \mathrm{~L})$ with $9.7 \mathrm{~cm}$ diameter, $69 \mathrm{~cm}$ height and double glassed walls; (6) Effluent point after the gas-liquid-solid (GLS) separator; (7) Gas sampling and gas counter (Ritter MGC-1V3.3 PMMA).

\subsubsection{Physico-chemical analysis}

The influent flow rate was determined by effluent collection during approximately 24 hours. Analyzed effluent was not older than one day and BW samples $(0.5 \mathrm{~L})$ were taken from the storage tank. TSS and VSS concentrations were determined by gravimetric standard method (Clesceri et al., 1998). COD ${ }_{\text {Total }}$ was determined by Hach Lange kits LCK014 from the unfiltered sample. Both $\mathrm{COD}_{\text {Colloidal }}$ and $\mathrm{COD}_{\text {soluble }}$ were quantified by Hach Lange kits LCK514, using paper filtered (black ribbon paper filter (Schleicher \& Schuell)) and membrane filtered (0.45 $\mu \mathrm{m}$ membrane Cronus filter PTFE) samples, respectively. TOC and its derivatives IC and TC were determined by the Shimadzu TOC analyzer out of paper filtered sample. Concentration of VFA, $\mathrm{NH}_{4}^{+}$, and anions was measured by ion chromatography (Metrohm 761 Compact), using membrane filtered sample. Inductively coupled plasma optical emission spectrometry (Perkin Elmer Optima 5300 DV ICP-OES) was used to determine the total and soluble elements in unfiltered and membrane filtered samples, 
respectively. Unfiltered samples were submitted to $\mathrm{HNO}_{3}$ digestion using microwave induced heating (MWD Milestone) at $148^{\circ} \mathrm{C}$ during $45 \mathrm{~min}$ prior to ICP-OES analysis. The biogas composition was measured by gas chromatography (Varian CP4900 Micro GC with two separate column models Mol Sieve $5 \AA ̊$ PLOT (MS5) and PoraPLOT U (PPU)).

\subsubsection{Granule separation and characterization}

Sludge bed samples of $55 \mathrm{ml}$ were taken at 5,10,20, and $30 \mathrm{~cm}$ high from the bottom in both reactors. The samples were taken from the top of the reactors with a $0.5 \mathrm{~cm}$ wide and $50 \mathrm{~cm}$ long hose connected to a syringe, sampling at the aforementioned heights from top to bottom. Then, the sludge samples were fractioned with mesh sieves as $<0.4,0.4$ to $0.9,0.9$ to $1.4,1.4$ to $2.0,2.0$ to 2.5 , and $>2.5 \mathrm{~mm}$ diameter. The elemental composition of solids and TSS and VSS concentrations were analyzed for each size fraction. The elemental composition of solids was determined with ICP-OES after acid digestion, and the TSS and VSS were quantified with gravimetric standard method, both as previously described. The structure and elemental distribution of $\mathrm{CaP}$ granules were assessed using a scanning electron microscope (SEM, JEOL JSM-6480LV with backscattered detection at $20 \mathrm{kV}$ ) coupled with energy dispersive X-ray (EDX, NORAN Systems SIX Thermo Scientific, USA). CaP granules with 0.9 to $1.4,1.4$ to $2.0,2.0$ to 2.5 , and $>2.5 \mathrm{~mm}$ diameter were sectioned while frozen and vacuum dried before being analyzed with SEM-EDX.

\subsubsection{Geochemical modelling with Visual Minteq 3.0}

The saturation indexes (SI) of $\mathrm{Ca}_{x}\left(\mathrm{PO}_{4}\right)_{y}, \mathrm{CaCO}_{3}$ and $\mathrm{MgNH}_{4} \mathrm{PO}_{4}$ were calculated using the chemical speciation software Visual Minteq 3.1 (KTH, Sweden). The software uses the Davies model to calculate the activity coefficients of each aforementioned specie (Mullin, 2001). The SI of a certain specie (y) was calculated through eq. 3.1.

$S I=\log \frac{I A P_{y}}{K_{S p_{y}}}$ Equation 3.1

where $I A P_{y}$ is the ion activity product of the elements in $y$ and $K_{s p_{y}}$ is the solubility product constant of $y$. Then, for SI $>0 y$ is supersaturated, for $\mathrm{SI}<0 y$ is under saturation and for SI $=0 y$ is in apparent equilibrium.

The model components were $\mathrm{Ca}^{2+}, \mathrm{Mg}^{2+}, \mathrm{Fe}^{2+}, \mathrm{Na}^{+}, \mathrm{K}^{+}, \mathrm{NH}_{4}^{+}, \mathrm{PO}_{4}{ }^{3-}, \mathrm{HCO}_{3}^{-}$ (alkalinity), $\mathrm{Cl}^{-}, \mathrm{SO}_{4}{ }^{2-}, \mathrm{NO}_{3}{ }^{-}$, acetate, propionate, butyrate, soluble humic acids, and $\mathrm{pH}$. Humic acids were determined with liquid chromatography - organic carbon detection (LC-OCD, 
Model 8 with a NDIR-detector Siemens Ultramat $6^{\mathrm{E}}$ and UV and OND detectors Agilent 1260 Infinity). The numeric values of each component were adapted for each situation where SI was calculated according to the analyzed composition of BW.

\subsubsection{Calculations}

The COD of suspended solids $\left(\mathrm{COD}_{\mathrm{Ss}}\right), \mathrm{COD}_{\text {Colloidal, }}$ organic loading rate (OLR), HRT, solids retention time (SRT), and the methanization rate $\left(\mathrm{gCOD}-\mathrm{CH}_{4} \mathrm{~g}^{-1} \mathrm{COD}_{\text {Total }} \mathrm{BW}\right.$ ) were calculated as described by Graaff et al. (2010) and Halalsheh et al. (2005). The $\mathrm{HCO}_{3}$ concentration was calculated from the IC as a function of measured $\mathrm{pH}$ and temperature. The concentration of solids in each reactor (Solids, gTSS L ${ }^{-1}$ of reactor) was calculated according to eq. 3.2 for each sampling day $(350,415,436$, and 460$)$.

Solids $=\frac{\sum_{i=1}^{3}\left(x_{i} V_{i}\right)+\left(x_{4}\left(V_{T}-\sum_{i=1}^{3} V_{i}\right)\right)}{V_{\text {reactor }}}$

Equation 3.2

where for each height sampled $(5,10,20$, and $30 \mathrm{~cm})$, the TSS concentration $\left(x_{i}\right.$, gTSS L $^{-1}$ of sludge) was multiplied by the specific volume $\left(V_{i}\right)$ of each height, which was $0.55,0.55$, and $0.74 \mathrm{~L}$ for height 1,2 , and $3(i)$, respectively. For height $4, V_{4}$ was calculated by the difference between the total volume of the sludge bed $\left(V_{T}\right)$ at the sampling time and the cumulative volume of heights 1,2 , and 3 . Since $V_{T}$ of the sludge bed varied over time, the specific volume of height 4 varied, while heights 1,2, and 3 had a stable specific volume. The working volume $\left(V_{\text {reactor }}\right)$ of each reactor was $5.1 \mathrm{~L}$.

The concentration of Ash in each reactor (Solids ${ }_{A s h}$, gAsh $\mathrm{L}^{-1}$ of reactor) was calculated as in eq. 3.2, but using the Ash concentration (gAsh L-1 of sludge) for $x_{i}$, which was obtained after incineration of solids at $550^{\circ} \mathrm{C}$. The concentration of VSS in each reactor (Solids $_{V S S}, \mathrm{gVSS} \mathrm{L}^{-1}$ of reactor) was also calculated according to eq. 3.2, but using the VSS concentration (gVSS L-1 of sludge) for $x_{i}$, which was calculated by subtracting the TSS and Ash concentrations at each height sampled.

Between days 350 and 460, the discharge rate (production) of total solids (Solids rate $_{\text {, }}$ gTSS $^{-1}$ ) in each reactor was calculated according to the slope of the linear regression line (eq.3.3) of the cumulative sum of the total solids sampled and the total solids in the reactor $\left(X_{k}\right)$ for each of the four sampling days $\left(t_{k}=350,425,436\right.$, and 460). The same was performed for discharge rate of VSS (Solids $\left.s_{V S S, \text { rate }}, \mathrm{gVSS} \mathrm{d}^{-1}\right)$ and Ash (Solids Ash,rate $\left._{\text {, }} \mathrm{gAsh} \mathrm{d}^{-1}\right)$. 
Solids $_{\text {rate }}=\frac{\sum_{k}\left(t_{k}-\bar{t}\right)\left(X_{k}-\bar{X}\right)}{\sum_{k}\left(t_{k}-\bar{t}\right)^{2}}$

Equation 3.3

where $\bar{X}$ and $\bar{t}$ are the averages $(\mathrm{n}=4)$ of the aforementioned $X_{k}$ and $t_{k}$.

Measured Solids $s_{V S S, \text { rate }}$ in each reactor was compared to a theoretical estimation of the VSS yield (Solids $S_{V S S, \text { yield }}, \mathrm{gVSS} \mathrm{d}^{-1}$ ) based on the treatment performance using a first order kinetic model (eq. 3.4), which included hydrolysis rate of particulate COD, heterotrophic biomass growth and formation of cell debris as described in Tchobanoglous et al. (2004) and Graaff et al. (2010).

$$
\text { Solids }_{V S S, \text { yield }}=\frac{S_{S S}}{1+k_{h} \cdot S R T} \cdot a+\frac{Y \cdot S_{\text {Sol }}}{1+k_{d} \cdot S R T}+\frac{Y \cdot S_{\text {Sol }} \cdot f_{d} \cdot k_{d} \cdot S R T}{1+k_{d} \cdot S R T}+S_{S S_{\text {non-biodegradable }}} \cdot a
$$

Equation 3.4

where $S_{S S}$ is the loading of biodegradable suspended COD retained in the reactor $\left(\mathrm{gCOD} \mathrm{d}^{-1}\right)$, $k_{h}$ is the hydrolysis constant $\left(0.1 \mathrm{~d}^{-1}\right.$, taken from Graaff et al. (2010)), $a$ is the measured ratio between VSS and suspended COD in BW (0.6 $\mathrm{gVSS} \mathrm{g}^{-1}$ of CODss), $Y$ is the biomass yield (0.14 $\mathrm{gVSS} \mathrm{g}^{-1}$ of $\left.\mathrm{COD}_{\text {converted }}\right)$, which was adapted for both reactors from Feng et al. (2006), $S_{s o l}$ is the converted soluble COD $\left(\mathrm{gCOD} \mathrm{d}^{-1}\right), k_{d}$ is the decay coefficient $\left(0.03 \mathrm{~d}^{-1}\right)$, and $f_{d}$ is the fraction of cell debris which remains as non-biodegradable $\left(0.15 \mathrm{gVSS} \mathrm{g}^{-1}\right.$ of VSS), both constants were taken from Tchobanoglous et al. (2004) and Feng et al. (2006). $S_{S S_{\text {non-biodegradable }}}$ is the non-biodegradable fraction of suspended COD in BW, which represented $16 \%$ of the suspended COD in BW according to Chaggu et al. (2007).

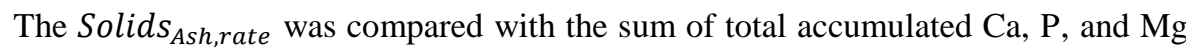
during the period between days 350 and $460\left(\mathrm{~g} \mathrm{~d}^{-1}\right)$. This accumulation was calculated from the difference between weekly determined influent (BW) and effluent concentrations of total $\mathrm{P}, \mathrm{Ca}$, and $\mathrm{Mg}$ for each reactor.

The $\mathrm{P}$ recovery efficiency as $\mathrm{CaP}$ granules (particles $>0.4 \mathrm{~mm}$ diameter) was calculated by dividing the total mass of $\mathrm{P}$ in $\mathrm{CaP}$ granules harvested from the reactor and the total incoming $\mathrm{P}$ from $\mathrm{BW}$, during phase 2. The total mass of $\mathrm{P}$ harvested as $\mathrm{CaP}$ granules $\left(P_{\text {Recovered }}, \mathrm{mgP}\right)$ was calculated according to eq. 3.5 , for each of the aforementioned sampling days. 
$P_{\text {Recovered }}=\sum_{i=1}^{4}\left(\sum_{h=1}^{5} x_{i} V_{s_{i}} f_{h_{i}} P_{h_{i}}\right)$

Equation 3.5

where $i$ refers to the sampling heights as aforementioned, $V_{s_{i}}$ is the volume of sludge sampled in each reactor height $(\mathrm{L}), h$ is the size fractions considered as CaP granules $(0.4$ to $0.9,0.9$ to $1.4,1.4$ to $2,0,2.0$ to 2.5 , and $>2.5 \mathrm{~mm}$ ), $f_{h_{i}}$ is the mass proportion of each size fraction in the total sludge sample mass for each reactor height $\left(\mathrm{g} \mathrm{g}^{-1}\right)$, and $P_{h_{i}}$ is the $\mathrm{P}$ content of each size fraction and each reactor height $\left(\mathrm{mgP} \mathrm{g}^{-1}\right.$ of TSS).

\subsection{Results}

\subsubsection{Reactors performance}

The overall removal of $\mathrm{COD}_{\text {Total }}$ was stable above $80 \%$ for both reactors throughout the entire operation period, although in $\mathrm{R} 2$ the total calcium $(\mathrm{Ca})$ loading rate was increased up to $560 \mathrm{mg} \mathrm{d}^{-1}$ (Figure 3.2). The methanization rate stabilized at $0.47 \pm 0.10{\mathrm{gCOD}-\mathrm{CH}_{4} \mathrm{~g}}^{-}$ ${ }^{1}$ of $\mathrm{COD}_{\text {Total }}-\mathrm{BW}$ during phase 2 for both reactors (Table 3.1). Moreover, accumulation of VFA in the effluent $\left(<0.02 \mathrm{gCOD} \mathrm{L}^{-1}\right.$ for both reactors) was not observed during the entire operational period. Phase 1 was longer than the obtained SRT for both reactors, and the SRT became shorter during phase 2. However, in both phases the SRT was higher in R2 than in R1 (Table 3.1). The detailed BW and effluent compositions for R1 and R2 are given in Table 3.2.
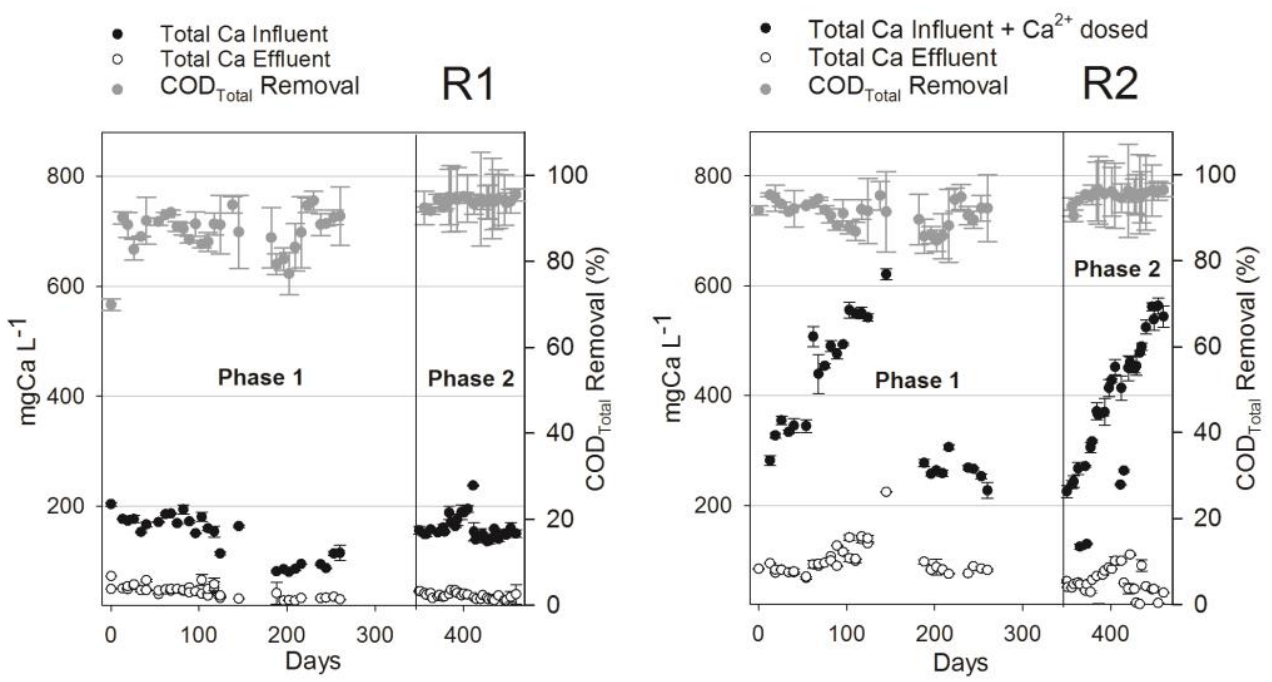

Figure 3.2 Influent and effluent total $\mathrm{Ca}$ concentrations and $\mathrm{COD}_{\mathrm{Total}}$ removal for reactors $\mathrm{R} 1$ (left) and R2 (right) during phase 1 (0-350) and phase 2 (day 350460 ). 
Table 3.1 Key performance parameters for the anaerobic treatment of black water for UASB reactors R1 and R2, with and without calcium addition, respectively, for phases 1 and 2 (average values).

\begin{tabular}{|c|c|c|c|c|c|c|c|c|c|}
\hline & & $\begin{array}{c}\text { Phase } \\
1\end{array}$ & & & & $\begin{array}{c}\text { Phase } \\
2\end{array}$ & & & \\
\hline Parameter & Unit & $\mathbf{R} 1$ & $\mathrm{sd}$ & $\mathbf{R 2}$ & sd & $\mathbf{R} 1$ & $\mathrm{sd}$ & $\mathbf{R 2}$ & $\mathrm{sd}$ \\
\hline HRT & Days & 7.75 & 0.64 & 7.03 & 0.66 & 8.43 & 0.78 & 7.12 & 0.41 \\
\hline OLR & $\mathrm{gCOD}_{\text {Total }} \mathrm{L}^{-1} \mathrm{~d}^{-1}$ & 1.03 & 0.39 & 1.14 & 0.41 & 1.33 & 0.18 & 1.61 & 0.22 \\
\hline $\mathrm{COD}_{\text {Total }}$ Removal & $\%$ & 86.79 & 5.04 & 90.92 & 3.03 & 93.97 & 0.95 & 95.28 & 1.34 \\
\hline $\mathrm{COD}_{\text {Soluble }}$ Removal & $\%$ & 72.84 & 18.63 & 83.12 & 9.87 & 84.70 & 1.38 & 87.83 & 1.47 \\
\hline Methanization & $\mathrm{gCOD} \mathrm{CH}_{4} \mathrm{~g}^{-1}$ of $\mathrm{COD}_{\text {Total }}-\mathrm{BW}$ & 0.64 & 0.28 & 0.51 & 0.19 & 0.47 & 0.10 & 0.47 & 0.09 \\
\hline Methane Production & $\mathrm{LCH}_{4} \mathrm{~L}^{-1}$ of BW & 2.13 & 1.13 & 1.76 & 0.94 & 2.06 & 0.42 & 2.00 & 0.29 \\
\hline SRT & Days & 180 & & 239 & & 163 & & 186 & \\
\hline
\end{tabular}


Table 3.2 Averaged influent and effluent chemical composition for the 460 days of operation.

\begin{tabular}{|c|c|c|c|c|c|c|c|}
\hline Parameter & Unit & BW & $s d$ & $\begin{array}{l}\text { R1 } \\
\text { Effluent }\end{array}$ & $s d$ & $\begin{array}{l}\text { R2 } \\
\text { Effluent }\end{array}$ & $s d$ \\
\hline pH & & 7.94 & 0.33 & 7.44 & 0.05 & 7.30 & 0.08 \\
\hline $\operatorname{COD}_{\text {Total }}$ & $\mathrm{gCOD} \mathrm{L}^{-1}$ & 9.50 & 2.64 & 0.90 & 0.34 & 0.62 & 0.27 \\
\hline $\operatorname{COD}_{\text {Soluble }}$ & $\mathrm{gCOD} \mathrm{L}^{-1}$ & 3.02 & 1.05 & 0.53 & 0.22 & 0.36 & 0.18 \\
\hline VFA & $\mathrm{gCOD} \mathrm{L}^{-1}$ & 2.06 & 0.99 & $<0.05$ & & $<0.05$ & \\
\hline $\mathrm{NH}_{4}{ }^{+}$ & $\mathrm{g} \mathrm{L}^{-1}$ & 0.85 & 0.10 & 0.77 & 0.14 & 0.75 & 0.12 \\
\hline $\mathrm{HCO}_{3}{ }^{-}$ & $\mathrm{g} \mathrm{L}^{-1}$ & 1.74 & 0.61 & 2.18 & 0.99 & 2.10 & 0.51 \\
\hline $\mathbf{P}_{\text {Total }}$ & $\mathrm{mg} \mathrm{L}^{-1}$ & 176.56 & 65.82 & 53.82 & 22.54 & 17.67 & 8.68 \\
\hline PSoluble & $\mathrm{mg} \mathrm{L}^{-1}$ & 53.69 & 10.50 & 50.35 & 18.09 & 14.02 & 4.74 \\
\hline $\mathrm{PO}_{4}{ }^{3-}-\mathrm{P}$ & $\mathrm{mg} \mathrm{L}^{-1}$ & 49.14 & 17.59 & 46.53 & 13.31 & 11.78 & 6.75 \\
\hline CaTotal* & $\mathrm{mg} \mathrm{L}^{-1}$ & 160.46 & 49.38 & 41.17 & 17.73 & 82.75 & 31.93 \\
\hline Casoluble* & $\mathrm{mg} \mathrm{L}^{-1}$ & 52.82 & 10.49 & 32.00 & 15.10 & 77.77 & 27.70 \\
\hline $\mathbf{M g}_{\text {Total }}$ & $\mathrm{mg} \mathrm{L}^{-1}$ & 66.76 & 37.18 & 13.97 & 5.61 & 36.06 & 12.16 \\
\hline MgSoluble & $\mathrm{mg} \mathrm{L}^{-1}$ & 11.18 & 7.59 & 12.82 & 3.02 & 37.45 & 12.81 \\
\hline$K_{\text {Soluble }}$ & $\mathrm{mg} \mathrm{L}^{-1}$ & 231.23 & 13.82 & 242.35 & 24.44 & 222.13 & 9.56 \\
\hline Nasoluble & $\mathrm{mg} \mathrm{L}^{-1}$ & 362.47 & 16.65 & 351.97 & 12.71 & 327.73 & 10.63 \\
\hline Humic acids & mgC L-1 & 104.15 & 36.32 & 77.58 & 5.51 & 61.74 & 9.64 \\
\hline
\end{tabular}

* The calcium loading for reactor $\mathrm{R} 2$ was $392.51 \pm 120.57 \mathrm{mgCa} \mathrm{L}^{-1}$, with a maximum and minimum of 773.40 and $124.92 \mathrm{mgCa} \mathrm{L}^{-1}$, respectively.

\subsubsection{Phosphorus removal}

The removal of total $\left(176 \pm 66 \mathrm{mgP} \mathrm{L}{ }^{-1}\right)$ and soluble $\mathrm{P}\left(50 \pm 17 \mathrm{mgPO}_{4}{ }^{3-}-\mathrm{P} \mathrm{L}^{-1}\right)$ from BW was significantly enhanced by adding $\mathrm{Ca}^{2+}$ (Figure 3.3). Without $\mathrm{Ca}^{2+}$ addition (R1), the removal of total $\mathrm{P}$ was $68 \pm 10 \%$, and the removal of soluble $\mathrm{P}$ fluctuated with the $\mathrm{Ca}^{2+}$ concentration in the influent (Figure 3.3a). For values of soluble $\mathrm{Ca}^{2+}$ below $40 \mathrm{mg} \mathrm{L}^{-1}$, the $\mathrm{PO}_{4}{ }^{3-}$ concentration increased in the effluent during the treatment. The effluent concentration of $\mathrm{PO}_{4}{ }^{3-}$ in $\mathrm{R} 1$ was $46 \pm 13 \mathrm{mgPO}_{4}{ }^{3-}-\mathrm{P} \mathrm{L}^{-1}$. The increase of $\mathrm{Ca}^{2+}$ from $144 \pm 21$ to $460 \pm 13 \mathrm{mg}$ $\mathrm{L}^{-1}$ increased $\mathrm{PO}_{4}{ }^{3-}$ removal from $74 \pm 9$ to $89 \pm 2 \%$. The removal of total $\mathrm{P}$ in $\mathrm{R} 2$ was $89 \pm$ $5 \%$ during the entire operational period (Figure 3.3a). Based on the difference between 
influent and effluent $\mathrm{Ca}$ and $\mathrm{P}$ concentrations in $\mathrm{R} 1$ and $\mathrm{R} 2$, the $\mathrm{Ca} / \mathrm{P}$ molar ratio of the $\mathrm{Ca}$ and $\mathrm{P}$ retained in the reactors is calculated and correlated with the influent $\mathrm{Ca}^{2+}$ concentration

(Figure 3.3c). For $\mathrm{R} 1$, the retained $\mathrm{Ca} / \mathrm{P}$ molar ratio was $0.78 \pm 0.17$ at a $\mathrm{Ca}^{2+}$ concentration in $\mathrm{BW}$ of $52 \pm 10 \mathrm{mg} \mathrm{L}^{-1}$, while in $\mathrm{R} 2$ this ratio increases with the increase of the $\mathrm{Ca}^{2+}$ concentration, to $1.19 \pm 0.06$ at $144 \pm 21 \mathrm{mgCa}^{2+} \mathrm{L}^{-1}$ of BW and further to $3.01 \pm 0.21$ at 460 $\pm 13 \mathrm{mgCa}^{2+} \mathrm{L}^{-1}$ of $\mathrm{BW}$.

a)

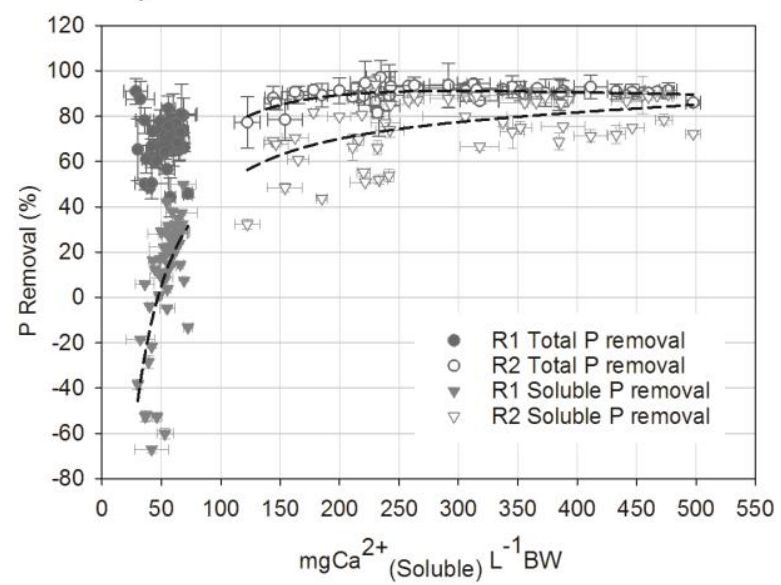

b) c)

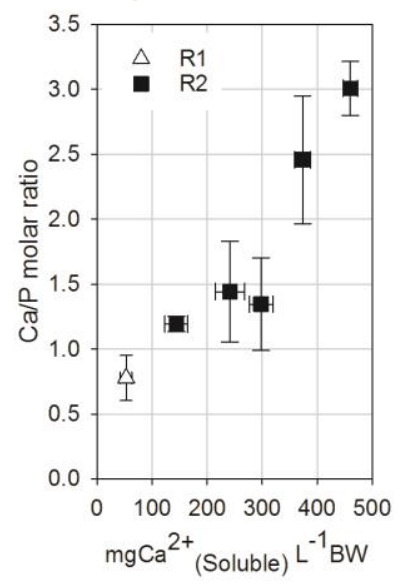

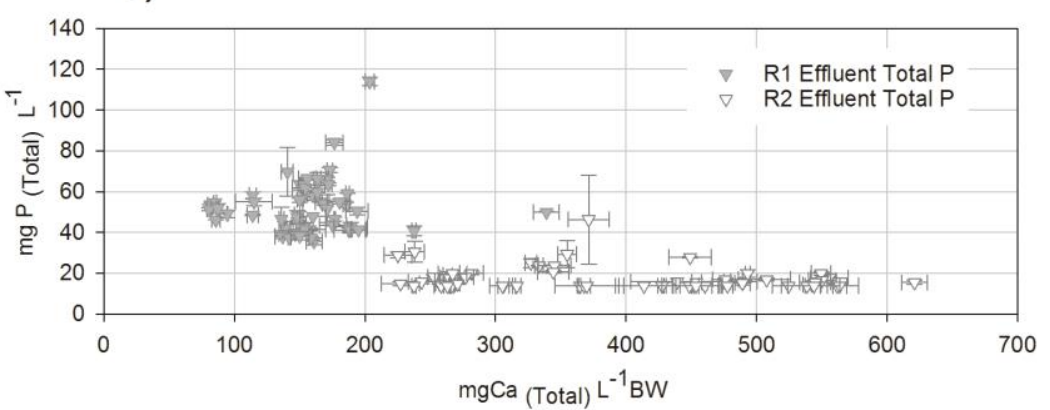

Figure 3.3 Correlation between the soluble $\mathrm{Ca}\left(\mathrm{Ca}^{2+}\right)$ concentration in $\mathrm{BW}$ and the total and soluble $\mathrm{P}$ removal (a). Effluent total $\mathrm{P}$ concentration (b). Negative removal of soluble $\mathrm{P}$ is due to hydrolysis of organically bound $\mathrm{P}$ in the influent BW. Both a) and b) are based on weekly measurements over the operation period of 460 days for $\mathrm{R} 1$ and $\mathrm{R} 2$. Ca to $\mathrm{P}$ molar ratio of total accumulated $\mathrm{Ca}$ and $\mathrm{P}$, was based on the difference between influent and effluent concentrations over the entire operational period of 460 days for R 1 and from day 350 and 460 for R2, which was further divided according to the averaged $\mathrm{Ca}^{2+}$ loading (c). 


\subsubsection{Particle size distribution of the sludge bed and discharge of solids over time}

By adding $\mathrm{Ca}^{2+}$, the concentration of $\mathrm{CaP}$ granules (particles $>0.4 \mathrm{~mm}$ diameter) in the sludge bed at the end of phase 1 (350 days) increased from 29 (R1) to 46 (R2) gTSS $\mathrm{kg}^{-1}$ of sludge, representing $63 \%$ and $81 \%$ of the total concentration of solids, respectively (Figure 3.4). Then, both the concentration of total solids and $\mathrm{CaP}$ granules remained stable for $\mathrm{R} 2$ during phase 2 , while a decrease in the total sludge concentration was observed in R1. In this phase a more frequent sampling was conducted, which made it unnecessary to purge sludge from the top of the sludge bed for both reactors.

The discharge rate (production) of total solids in R2 $\left(1.075 \pm 0.179\right.$ gTSS d $^{-1}$ and $0.131 \mathrm{gTSS} \mathrm{g}^{-1}$ of $\left.\mathrm{COD}_{\text {influent }}\right)$ was higher than in R1 $\left(0.691 \pm 0.078 \mathrm{gTSS} \mathrm{d}^{-1}\right.$ and $0.102 \mathrm{gTSS}^{-1}$ $\mathrm{g}^{-1}$ of $\left.\mathrm{COD}_{\text {influent }}\right)$, but the discharge rate of VSS was similar in both reactors $(0.074$ and 0.083 $\mathrm{gVSS} \mathrm{g}^{-1}$ of $\mathrm{COD}_{\text {influent }}$ for R1 and R2, respectively) (Figure 3.5a and $\mathbf{b}$ ). The calculated VSS yield was 0.087 and $0.085 \mathrm{gVSS} \mathrm{g}^{-1}$ of $\mathrm{COD}_{\text {influent }}$ for $\mathrm{R} 1$ and $\mathrm{R} 2$, respectively, representing a deviation of 15 and $3 \%$ for R1 and R2, respectively, when compared with the measured VSS production (dash line Figure 3.5a and $\mathbf{b}$ ). The average concentration of total solids inside the reactor during phase 2 was $34 \pm 1$ and $39 \pm 3 \mathrm{gTSS} \mathrm{L}^{-1}$ of reactor for R1 and R2, respectively.

The major difference between R1 and R2 was the Ash concentration in the discharged sludge $\left(0.184 \pm 0.135\right.$ and $0.395 \pm 0.271 \mathrm{gAsh} \mathrm{d}^{-1}$, respectively). A two fold increase in the Ash discharge rate was observed by adding $\mathrm{Ca}^{2+}$ in R2. Moreover, the Ash discharged rate in both R1 and R2 was proportional to the mass sum of $\mathrm{P}, \mathrm{Ca}$, and $\mathrm{Mg}$ accumulated in the reactor (solid line Figure 3.5a and $\mathbf{b}$ ), during phase 2; the cumulative rates were calculated from the cumulative difference between influent and effluent $\mathrm{P}, \mathrm{Ca}$, and $\mathrm{Mg}$ concentrations $(\mathrm{n}=28)$. The sum of accumulated $\mathrm{P}, \mathrm{Ca}$, and $\mathrm{Mg}$ was 0.03 and $0.07 \mathrm{~g} \mathrm{~L}^{-1}$ of reactor $\mathrm{d}^{-1}$ for $\mathrm{R} 1$ and $\mathrm{R} 2$, respectively.

The VSS, Ash, and $\mathrm{P}$ concentrations as CaP granules (particles $>0.4 \mathrm{~mm}$ diameter) over the height of both reactors are presented in Figure 3.5c and $\mathbf{d}$. The standard deviation was determined for averages of samples taken on days 350, 425, 436, and 460. Thus, for R1 (without $\mathrm{Ca}^{2+}$ addition), both the concentration (27 $\pm 3 \mathrm{gTSS} \mathrm{kg}^{-1}$ of sludge) and composition ( $20 \pm 2 \mathrm{gVSS} \mathrm{kg}^{-1}$ of sludge, $8 \pm 1 \mathrm{gAsh} \mathrm{kg}^{-1}$ of sludge and $1.0 \pm 0.2 \mathrm{gP} \mathrm{kg}^{-1}$ of sludge) of CaP granules were relatively constant along the reactor height. By adding $\mathrm{Ca}^{2+}(\mathrm{R} 2)$, an increase in concentration of CaP granules from top ( $22 \pm 1 \mathrm{gTSS} \mathrm{kg}^{-1}$ of sludge) to bottom (75 $\pm 5 \mathrm{gTSS}$ $\mathrm{kg}^{-1}$ of sludge) was observed. Moreover, the ratio Ash/VSS in CaP granules increased from top $(0.4 \pm 0.2)$ to bottom $(1.2 \pm 0.4)$ of the sludge bed, along with the $\mathrm{P}$ concentration as $\mathrm{CaP}$ granules (Figure 3.5d). 

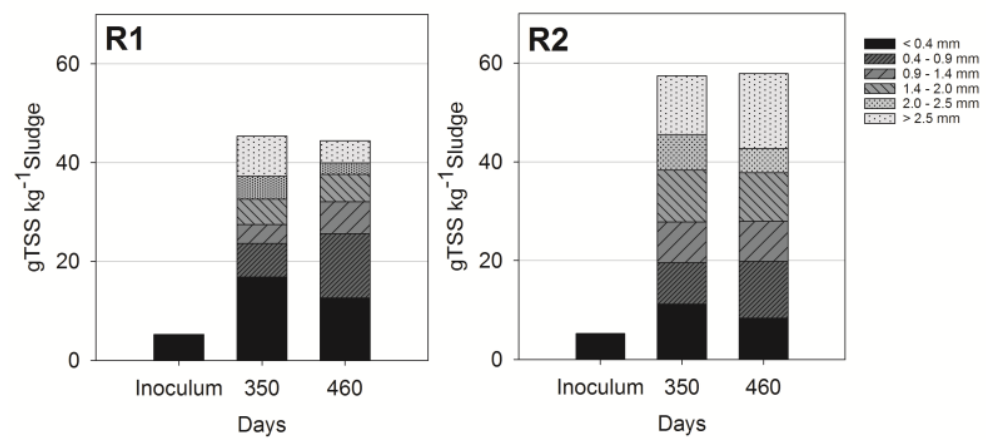

Figure 3.4 Particle size distribution and concentration of the inoculum and sludge bed on operation days 350 and 460 for reactors R1 (left) and R2 (right). The concentration of each size fraction is a result of sampling at 5,10,20, and $30 \mathrm{~cm}$ from the bottom of reactor and the total volume of the sludge bed at the sampling time.
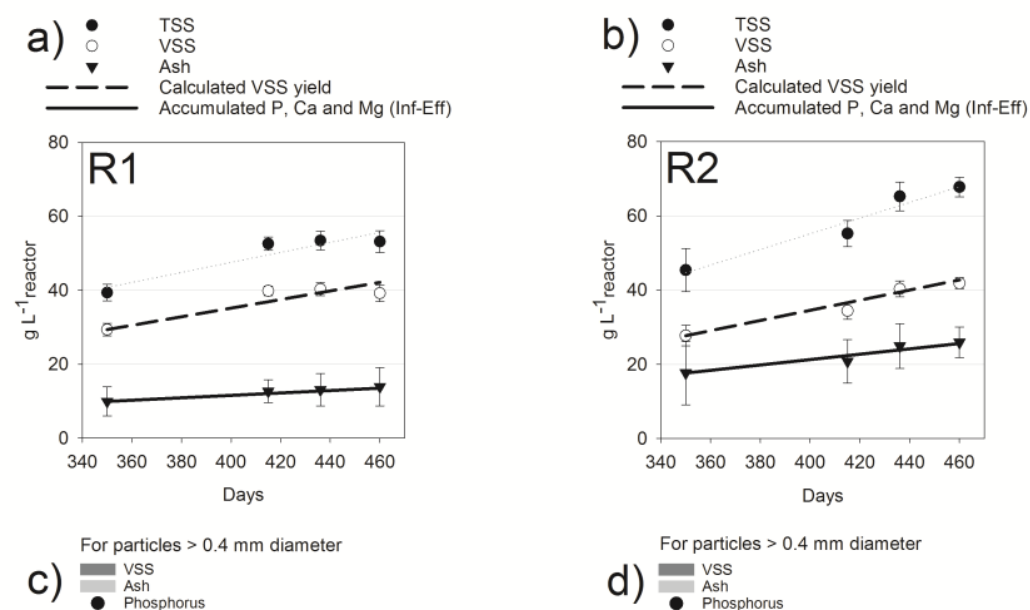

C) Ash
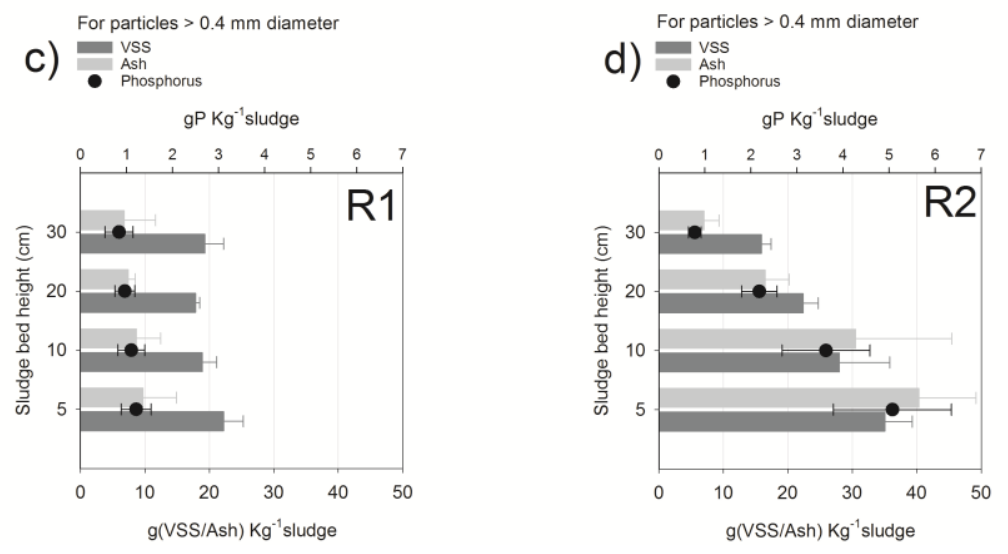

Figure 3.5 Concentration in the reactor plus cumulative discharge rate of total solids (TSS, VSS, and Ash), estimation of VSS yield based on hydrolysis and conversion of accumulated $\mathrm{COD}$ (dash line) and sum of accumulated $\mathrm{P}, \mathrm{Ca}$, and $\mathrm{Mg}$ based on difference between influent and effluent weekly concentrations (solid line) for R1 (a) and R2 (b), during phase 2. Vertical distribution of VSS, Ash, and phosphorus concentrations as particles $>0.4 \mathrm{~mm}$ diameter in the sludge bed of R1 (c) and R2 (d), during phase 2. 


\subsubsection{Composition and structure of calcium phosphate granules}

$\mathrm{Ca}^{2+}$ addition resulted in overall higher $\mathrm{P}$ content in the granules (Figure 3.7). This is observed in the lower part of the reactor (heights 5, 10, and $20 \mathrm{~cm}$ ) and not at the top. The $\mathrm{P}$ content of particles $<0.4 \mathrm{~mm}$ diameter from the reactor with $\mathrm{Ca}^{2+}$ addition (R2) was lower than particles with the same size range from R1. The highest $\mathrm{P}$ content was observed for granules with diameter between 2 and $2.5 \mathrm{~mm}$ in R2, located at $5 \mathrm{~cm}$ from the bottom $(82 \pm$ $10 \mathrm{mgP} \mathrm{g}^{-1}$ of TSS). During phase 2, the $\mathrm{Ca} / \mathrm{P}$ molar ratio in $\mathrm{CaP}$ granules was $1.14 \pm 0.14$ for reactor $\mathrm{R} 1$ and for reactor $\mathrm{R} 2$ it increases during phase 2 from $1.68 \pm 0.11$ on day 350 to 2.04 \pm 0.06 on day 460 . The $\mathrm{P}$ enrichment was associated with a decrease in VSS content for all size fractions in R2 (Figure 3.7e). SEM and SEM-EDX images of sliced granules from R1 and $\mathrm{R} 2$ are shown in Figure 3.6. $\mathrm{Ca}_{\mathrm{x}}\left(\mathrm{PO}_{4}\right)_{\mathrm{y}}$ precipitation in the granules, which is represented by green (overlay between cyan $(\mathrm{Ca})$ and yellow $(\mathrm{P})$ ) in the EDX images, was enhanced by $\mathrm{Ca}^{2+}$ addition. Besides $\mathrm{Ca}_{\mathrm{x}}\left(\mathrm{PO}_{4}\right)_{\mathrm{y}}, \mathrm{Mg}$ phosphate precipitates were also found in granules from $\mathrm{R} 1$, but not in R2. 


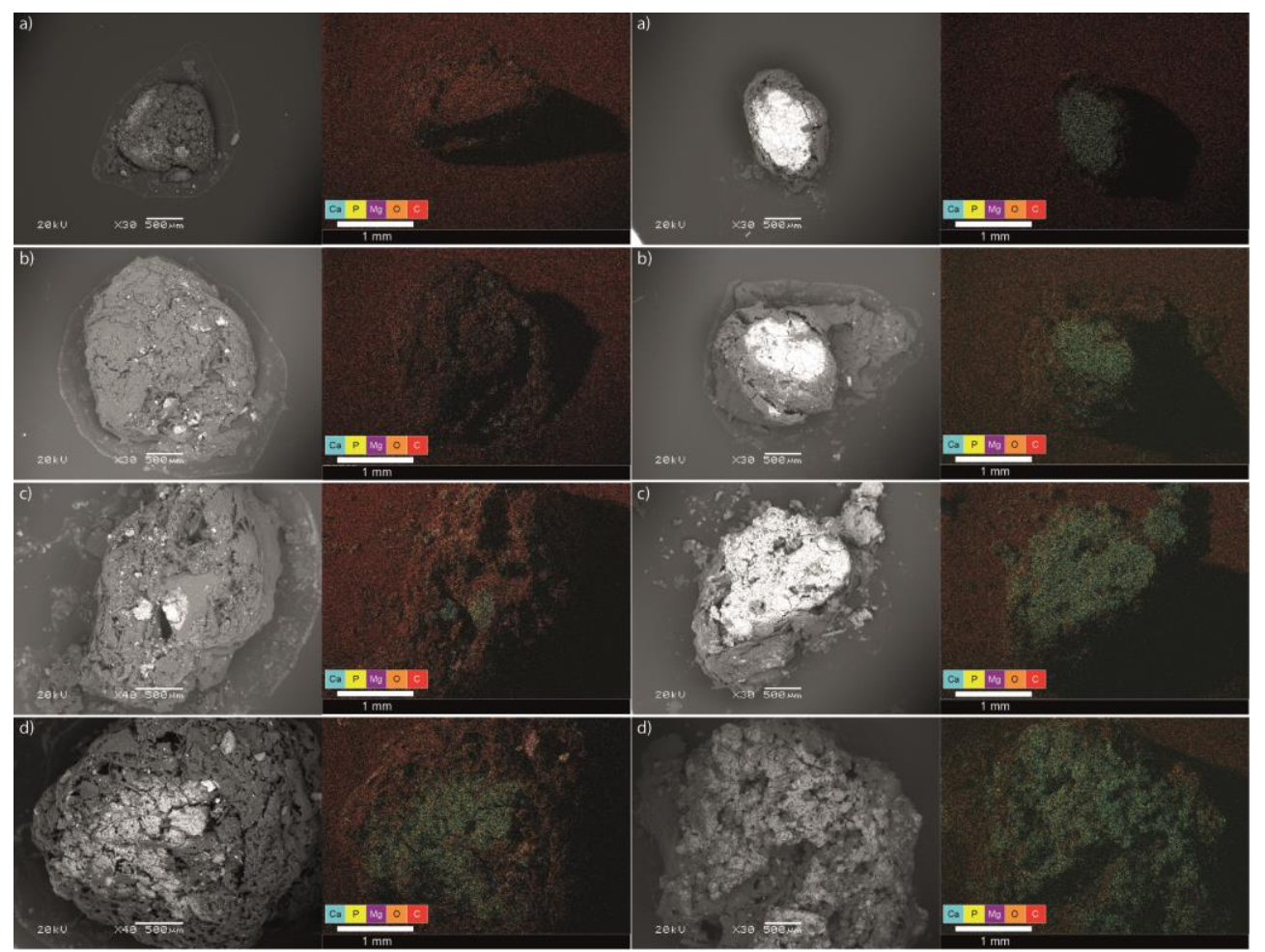

Figure 3.6 Backscattered SEM and SEM-EDX illustration of representative granule samples from R1 (left) and R2 (right) with diameter ranging from $0.9-1.4$ (a), $1.4-2.0$ (b), $2.0-2.5$ (c), and $>2.5 \mathrm{~mm}$ (d). The green color in the SEM-EDX scans are a result of overlay between cyan and yellow, representing $\mathrm{Ca}$ and $\mathrm{P}$, respectively. 


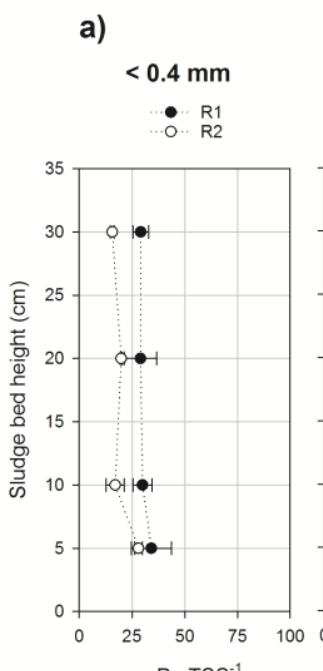

b) $0.4-0.9 \mathrm{~mm}$ $\because{ }^{\circ}{ }^{2} 1$

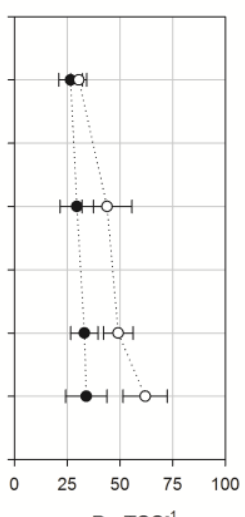

c)

$0.9-1.4 \mathrm{~mm}$

$\because$ R1

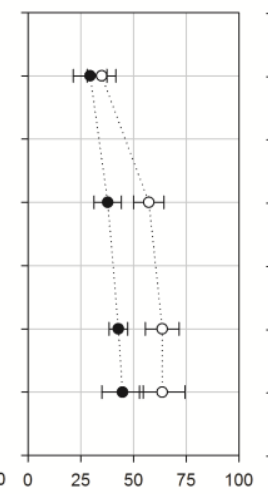

$\mathrm{mgP} \mathrm{g}$ TSS $^{-1}$ d)

$1.4-2.0 \mathrm{~mm}$

: $:{ }^{R 2}$

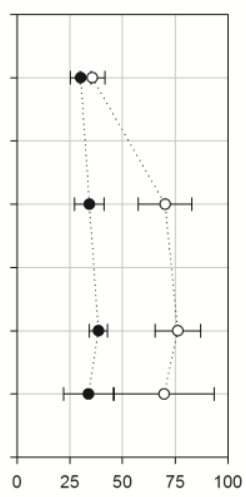

mgP gTSS ${ }^{-1}$ e)

$2.0-2.5 \mathrm{~mm}$

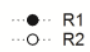

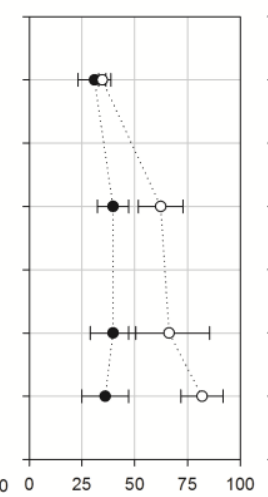

mgP gTSS ${ }^{-1}$

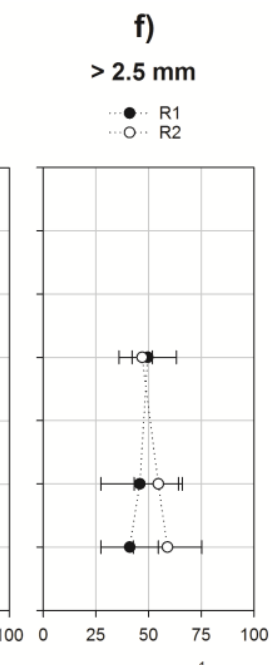

g)

$: \quad>2.5 \mathrm{~mm}$
$2.0-2.5 \mathrm{~mm}$

$1.4 .2 .0 \mathrm{~mm}$
$0.9-1.4 \mathrm{~mm}$

$0.9-0.9 \mathrm{~mm}$
$0.04 \mathrm{~mm}$

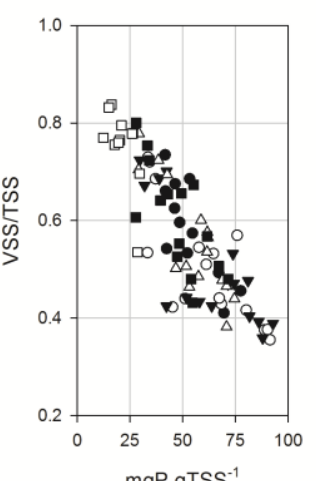

Figure 3.7 Average of phosphorus content for all size fractions $(<0.4,0.4-0.9,0.9-1.4,1.4-2.0,2.0-2.5$, and $>2.5 \mathrm{~mm}$ diameter $)$ at four different sludge bed heights of reactors R1 and R2 (a - f). Average values are from sampling on operation days 350, 415, 436, and 460. Correlation between phosphorus and VSS contents in dry solids for each size fraction sampled from reactor R2 during phase $2(\mathrm{~g})$. 


\subsection{Discussion}

\subsubsection{Effect of $\mathrm{Ca}^{2+}$ on treatment performance and $\mathrm{P}$ removal}

$\mathrm{Ca}^{2+}$ addition has shown to have both beneficial and detrimental effects on biological anaerobic treatment of wastewater. Anaerobic treatment of swine wastewater in an egg-shape digester, fresh leachate from municipal wastewater in an expanded granular sludge bed reactor, and synthetic wastewater (mixture of peptone, glucose and meat extract) in a UASB reactor was inhibited for values of $\mathrm{Ca}^{2+}$ to $\mathrm{COD}_{\text {Total }}$ above $0.04,0.07$, and $0.15 \mathrm{~g} \mathrm{~g}^{-1}$, respectively (Ahn et al., 2006; Dang et al., 2014; Yu et al., 2001). Formation of inorganic particles $\left(\mathrm{CaCO}_{3}\right)$ and consequent increase in mass transfer limitations between substrates and microorganisms caused the inhibition (Dang et al., 2014; Yu et al., 2001). Yet, for lower ratios of $\mathrm{Ca}^{2+}$ to $\mathrm{COD}_{\text {Total }}, \mathrm{Ca}^{2+}$ showed a beneficial effect on the anaerobic treatment performance. This was mainly due to two factors. One was neutralization of inhibitory effect of, for instance, long chain fatty acids (LCFA) in the liquid by precipitation of LCFA-Ca salts, and thereby increasing affinity to other organic substrates, such as propionate and valerate (Ahn et al., 2006; Dang et al., 2014). The other was increasing retention of sludge in the reactor by enhancing microbial granulation mechanisms such as adsorption, adhesion, and multiplication, due to the capacity of $\mathrm{Ca}^{2+}$ to bridge with electronegative functional groups characteristic of the outer surface of microorganisms (Cao et al., 2014; Shen et al., 1993; Yu et al., 2001). Although $\mathrm{Ca}^{2+}$ was added in $\mathrm{R} 2\left(0.043 \pm 0.016 \mathrm{~g} \mathrm{Ca}^{2+} \mathrm{g}^{-1}\right.$ of $\left.\mathrm{COD}_{\text {Total }}\right)$, no significant inhibition was observed after the process stabilization (phase 2), because COD removal and $\mathrm{CH}_{4}$ production were nearly equal in both reactors. Moreover, the measured VSS yield was similar for both reactors (Figure 3.5a and b), indicating that biomass growth was comparable with and without $\mathrm{Ca}^{2+}$ addition. Thus, addition of extra $\mathrm{Ca}^{2+}$ in $\mathrm{R} 2$ as described in Figure 3.2 did not affect the BW treatment.

Without $\mathrm{Ca}^{2+}$ addition (R1), the $\mathrm{PO}_{4}{ }^{3-}$ removal was largely influenced by the $\mathrm{Ca}^{2+}$ concentration in the influent BW. According to geochemical modelling in BW a change in $\mathrm{Ca}^{2+}$ from 40 to $50 \mathrm{mg} \mathrm{L}^{-1}$ triggers supersaturation for amorphous calcium phosphate (ACP), which is a precursor of apatite (the more stable $\mathrm{Ca}_{\mathrm{x}}\left(\mathrm{PO}_{4}\right)_{\mathrm{y}}$ phase); the SI for ACP increased from -0.258 to 0.257 . ACP has kinetical advantage to form over apatite due to the higher solubility product constant $\left(\mathrm{K}_{\mathrm{sp}}\right) ; \mathrm{K}_{\mathrm{sp}}$ values for ACP and apatite considered in this study are $5.6 \times 10^{-29}$ and $4.7 \times 10^{-45}$, respectively (Visual Minteq). Supersaturation for octacalcium phosphate (OCP), which is an intermediate phase between ACP and apatite (Habraken et al., 2013), was also triggered by the increase in $\mathrm{Ca}^{2+}$ (SI rose from -0.568 to 0.118). Since 
$\mathrm{Ca}_{\mathrm{x}}\left(\mathrm{PO}_{4}\right)_{\mathrm{y}}$ precursors are undersaturated for $\mathrm{Ca}^{2+}$ concentrations in the influent $\mathrm{BW}$ below 50 $\mathrm{mg} \mathrm{L}^{-1}$ (Figure 3.3a), hydrolysed organic $\mathrm{P}$ is not precipitated and leaves the reactor in the effluent. This explains the negative removal of $\mathrm{PO}_{4}{ }^{3-}$, and confirms that $\mathrm{Ca}^{2+}$ in $\mathrm{BW}$ is limiting the $\mathrm{P}$ accumulation in the reactor. By adding $\mathrm{Ca}^{2+}$, the $\mathrm{PO}_{4}{ }^{3-}$ removal further increases up to $89 \%$. Accumulation of non-hydrolysable solid $\mathrm{P}$ was nearly complete even without $\mathrm{Ca}^{2+}$ addition. This is mostly due to the capacity for retention of solids in the gas-liquid-solid separator (GLS) on top of the UASB reactor (Figure 3.1).

The possible mineral phases for $\mathrm{P}$ in the UASB reactor considering the chemical composition of the influent BW are $\mathrm{MgNH}_{4} \mathrm{PO}_{4}$ (struvite) and $\mathrm{Ca}_{\mathrm{x}}\left(\mathrm{PO}_{4}\right)_{\mathrm{y}}(\mathrm{Graaff}$ et al., 2011a; Tervahauta et al., 2014c). Moreover, the theoretical $\mathrm{Ca} / \mathrm{P}$ molar ratio of $\mathrm{Ca}_{\mathbf{x}}\left(\mathrm{PO}_{4}\right)_{\mathrm{y}}$ phases ranges between 1.1 and 1.67, where the highest is for apatite (Habraken et al., 2013). Thus, considering the $\mathrm{Ca} / \mathrm{P}$ molar ratio of $\mathrm{P}$ and $\mathrm{Ca}$ retained in the reactor without $\mathrm{Ca}^{2+}$ addition (0.78), $\mathrm{P}$ accumulated as both struvite and $\mathrm{Ca}_{\mathrm{x}}\left(\mathrm{PO}_{4}\right)_{\mathrm{y}}$. The increased supersaturation of $\mathrm{Ca}_{\mathrm{x}}\left(\mathrm{PO}_{4}\right)_{\mathrm{y}}$ phases led to the dissolution of struvite in $\mathrm{R} 2$. This is supported by: the higher concentration of soluble $\mathrm{Mg}\left(\mathrm{Mg}^{2+}\right)$ in R2 effluent $\left(37 \pm 13 \mathrm{mg} \mathrm{L}^{-1}\right)$ compared to R1 effluent $\left(13 \pm 3 \mathrm{mg} \mathrm{L}^{-1}\right)$ as shown in Table 3.2, and the higher $\mathrm{Mg}$ content in $\mathrm{CaP}$ granules from $\mathrm{R} 1$ than from R2. For values of influent $\mathrm{Ca}^{2+}$ between 144 and $350 \mathrm{mg} \mathrm{L}^{-1}, \mathrm{P}$ and $\mathrm{Ca}$ accumulated mainly as $\mathrm{Ca}_{x}\left(\mathrm{PO}_{4}\right)_{y}$ in $\mathrm{R} 2$ (Figure 3.3c). For higher influent $\mathrm{Ca}^{2+}$ concentrations (from 350 to $460 \mathrm{mg} \mathrm{L}^{-1}$ ), the $\mathrm{Ca} / \mathrm{P}$ molar ratio of $\mathrm{P}$ and $\mathrm{Ca}$ retained in the reactor (3.01) exceed the reference 1.67 and the $\mathrm{PO}_{4}{ }^{3-}$ removal was not significantly higher, when compared with lower influent $\mathrm{Ca}^{2+}$ concentrations as shown in Figure 3.3a. This suggests that added $\mathrm{Ca}^{2+}$ likely coprecipitated as $\mathrm{CaCO}_{3}$ (Langerak et al., 1998) and complexed with microorganisms, extracellular polymeric substances (EPS), and humic acids, due to their negatively charged functional groups (Jia et al., 1993; Liao et al., 2001; Morgan et al., 1990; Wilén et al., 2003). The concentration of humic acids in $\mathrm{R} 2$ effluent $\left(47.8 \pm 9.6 \mathrm{mgC} \mathrm{L}^{-1}\right)$ was on average lower than in $\mathrm{R} 1$ effluent $\left(59.5 \pm 5.5 \mathrm{mgC} \mathrm{L}^{-1}\right)$, indicating complexation of $\mathrm{Ca}^{2+}$ with humic acids. Note that in the influent (BW) the concentration of humic acids was $88.3 \pm 5.7 \mathrm{mgC} \mathrm{L}^{-1}$. Therefore, addition of $\mathrm{Ca}^{2+}$ above $250 \mathrm{mg} \mathrm{L}^{-1}$ (total of $300 \mathrm{mgCa}^{2+} \mathrm{L}^{-1}$ in the reactor or a $\mathrm{Ca}^{2+} / \mathrm{PO}_{4}{ }^{3-}$ molar ratio higher than 5) is not contributing to further $\mathrm{P}$ accumulation after the process stabilization, but rather inducing undesired $\mathrm{Ca}^{2+}$ bonds, such co-precipitation of $\mathrm{CaCO}_{3}$.

\subsubsection{Effect of $\mathrm{Ca}^{2+}$ on the particle size distribution and composition}

Particle size, composition and distribution in the sludge bed are crucial features for further improvement of harvesting, separation and use of CaP granules. Granulation is 
commonly observed when shear force, which is induced by the generally applied upflow velocity in UASB reactors ( 1 to $3 \mathrm{~m} \mathrm{~h}^{-1}$ ), creates a selection pressure in the microbial community, causing preferable retention of microbial aggregates over suspended biomass (Hulshoff Pol et al., 2004; Liu and Tay, 2004; Zhou et al., 2006). However, for BW treatment this selection pressure is reduced due to the low upflow velocity in the UASB reactor $(<0.01$ $\mathrm{m} \mathrm{h}^{-1}$ ), which is required to ensure the disintegration/hydrolysis of solid COD in BW. According to Hulshoff Pol et al. (2004) microorganisms have ecological advantages when attached to a surface, such as stability, protection against toxic compounds, kinetic advantage for uptake of substrates, and facilitation of syntrophic relationships between microorganisms (Hulshoff Pol et al., 2004; Schmidt and Ahring, 1996; Yoda et al., 1989). Thus, the microbial colonization on seed particles (e.g. $\mathrm{CaCO}_{3}$, ACP, or OCP, which can act as a nucleus), and the consequent development of an outer biofilm is likely the initiation mechanism for $\mathrm{CaP}$ granulation. The higher $\mathrm{P}$ content in particles $<0.4 \mathrm{~mm}$ diameter $\left(38 \pm 8\right.$ and $31 \pm 9 \mathrm{mgP} \mathrm{g}^{-1}$ of VSS for R1 and R2, respectively) when compared to common anaerobic biomass (10 - 14 $\mathrm{mgP} \mathrm{g}^{-1}$ of VSS), supports the presence of particles containing $\mathrm{P}$ in the bulk which could serve as initial seeds (Arne Alphenaar et al., 1993; Langerak et al., 1998). Then, due to local favorable conditions (higher $\mathrm{pH}), \mathrm{Ca}_{\mathrm{x}}\left(\mathrm{PO}_{4}\right)_{\mathrm{y}}$ prevails, grows, and recrystallizes to more stable phases in the granule core as previously suggested by Cunha et al. (2017) and Mañas et al. (2012). The higher $\mathrm{pH}$ is probably induced by degradation of organic acids and conversion of $\mathrm{H}_{2}, \mathrm{H}^{+}$, and $\mathrm{HCO}_{3}{ }^{-}$into $\mathrm{CH}_{4}$ in the outer biofilm. The reduction of $\mathrm{P}$ content in fine particles $\left(<0.4 \mathrm{~mm}\right.$ diameter) from R2 (Figure 3.7a) is the result of $\mathrm{Ca}^{2+}$ addition, which stimulated formation and enrichment of $\mathrm{Ca}_{x}\left(\mathrm{PO}_{4}\right)_{y}$ in existing granules over bulk precipitation.

Supplementation of $\mathrm{Ca}^{2+}$ increased the overall concentration of $\mathrm{CaP}$ granules $(>0.4$ $\mathrm{mm}$ ) in the UASB reactor. The role of $\mathrm{Ca}^{2+}$ on the formation of $\mathrm{CaP}$ granules consisted of increasing the concentration of seed particles that served as initial nuclei for $\mathrm{CaP}$ granulation and stimulating the agglomeration of biomass. The latter was due to bridging between extracellular proteins, developing an organic matrix which plays a key role in strengthening the granular structure (Batstone et al., 2002b; Caudan et al., 2014; Ismail et al., 2010; Ren et al., 2008). The measured and theoretical VSS production was similar in both reactors (Figure 3.5), but a larger fraction of the produced VSS were in $\mathrm{CaP}$ granules for the reactor where $\mathrm{Ca}^{2+}$ was added (69\%), when compared with no $\mathrm{Ca}^{2+}$ addition (56\%). This supports the beneficial effect of $\mathrm{Ca}^{2+}$ on biomass agglomeration, which contributes to the formation and growth of CaP granules. 
Regarding the core, $\mathrm{Ca}^{2+}$ directly participates in the formation of $\mathrm{Ca}_{\mathrm{x}}\left(\mathrm{PO}_{4}\right)_{\mathrm{y}}$ precipitates and growth of the existing $\mathrm{Ca}_{\mathrm{x}}\left(\mathrm{PO}_{4}\right)_{\mathrm{y}}$ core. By supplying $\mathrm{Ca}^{2+}$, the $\mathrm{Ca}_{\mathrm{x}}\left(\mathrm{PO}_{4}\right)_{\mathrm{y}}$ enrichment in $\mathrm{CaP}$ granules correlated with the granule size and it decreased from bottom to top of the sludge bed (Figure 3.5 and Figure 3.7). Yet, for granules $>2.5 \mathrm{~mm}$ diameter the $\mathrm{P}$ content was lower than granules between 0.9 and 2.5 (Figure 3.7). This is most likely caused by the fast growth of the outer biofilm, resulting in a large granule with high VSS and low $\mathrm{P}$ contents. Then, along with $\mathrm{Ca}_{\mathrm{x}}\left(\mathrm{PO}_{4}\right)_{\mathrm{y}}$ core maturation, recrystallization of amorphous phases into more stable $\mathrm{Ca}_{\mathrm{x}}\left(\mathrm{PO}_{4}\right)_{\mathrm{y}}$ phases and agglomeration of $\mathrm{Ca}_{\mathrm{x}}\left(\mathrm{PO}_{4}\right)_{\mathrm{y}}$ crystals occur (Angela Mañas et al., 2012), leading to a reduction in the pore size distribution (compactness) (Habraken et al., 2013). Consequently, less mineral surface is available for the outer biofilm, and the biological activity in the granules is pushed towards the edge of the granule, developing an outer layer 50 to $100 \mu \mathrm{m}$ thick as shown in Figure 3.6. Then, due to the higher density of the $\mathrm{Ca}_{\mathrm{x}}\left(\mathrm{PO}_{4}\right)_{\mathrm{y}}$ core and consequent higher settling velocity when compared with organic material, mature $\mathrm{CaP}$ granules settled at the bottom of the reactor, which is in this study the recommended harvesting location.

At the bottom of $\mathrm{R} 2$ (with $\mathrm{Ca}^{2+}$ addition), $\mathrm{CaP}$ granules contained $6.7 \pm 1.2 \mathrm{wt} \% \mathrm{P}$ (36 $\mathrm{wt} \%$ as apatite) with a $\mathrm{Ca} / \mathrm{P}$ molar ratio of 1.68 , which is close to the typical ratio of apatite. Moreover, the $\mathrm{Mg}$ content in $\mathrm{CaP}$ granules was below $0.5 \mathrm{wt} \%$, indicating low levels of struvite and $\mathrm{MgCO}_{3}$. However, the outer biofilm (VSS) of CaP granules represented $47 \pm 3 \mathrm{wt} \%$ at the bottom, which could limit the use of $\mathrm{CaP}$ granules as replacement for $\mathrm{P}$ rock. The remaining mass (17 wt \%) consisted of Ash from the VSS, $\mathrm{CaCO}_{3}$, and other trace elements. When a post separation (concentration) step, using for instance flotation and/or vibrating sieves, would be applied the organic fraction (VSS) in the CaP granules could be reduced, due to the density difference between the $\mathrm{Ca}_{\mathrm{x}}\left(\mathrm{PO}_{4}\right)_{\mathrm{y}}$ core and the outer biofilm. This would increase $\mathrm{P}$ content and reduce the organic proportion in the recovered product.

\subsubsection{Recovery of calcium phosphate granules and outlook for process optimization}

The $\mathrm{P}$ recovery as $\mathrm{CaP}$ granules (> $0.4 \mathrm{~mm}$ diameter) was $31 \%$ with $\mathrm{Ca}^{2+}$ addition and $14 \%$ without $\mathrm{Ca}^{2+}$ addition, considering the granules sampled during phase 2 and the total incoming P in BW. Of the total P sampled $94 \%$ and $72 \%$ was in CaP granules with and without $\mathrm{Ca}^{2+}$ addition, respectively. For both $\mathrm{R} 1$ and $\mathrm{R} 2$ the production of $\mathrm{CaP}$ granules was considerably higher than previously observed by Tervahauta et al. (2014c), who reported only $2 \%$ of the $\mathrm{P}$ as granules. The higher $\mathrm{P}$ recovery efficiency in $\mathrm{R} 1$ when compared with Tervahauta et al. (2014c) is explained by the higher accumulation of $\mathrm{P}$ in the reactor $(68 \%$ during phase 2 versus $51 \%$ ). This can be explained by a reduction in $\mathrm{HCO}_{3}{ }^{-}$concentration in 
BW during this study (from 3.6 (Tervahauta et al., 2014c) to $1.7 \mathrm{~g} \mathrm{~L}^{-1}$ ), decreasing the SI of $\mathrm{CaCO}_{3}$ and increasing the SI of $\mathrm{Ca}_{\mathrm{x}}\left(\mathrm{PO}_{4}\right)_{\mathrm{y}}$ phases by increasing the ionic activity of $\mathrm{Ca}^{2+}$ (Cunha et al., 2017). The higher accumulation of $\mathrm{P}$, stimulated the formation of $\mathrm{CaP}$ granules and $\mathrm{P}$ enrichment in the granules, leading to a higher recovery efficiency. By supplying $\mathrm{Ca}^{2+}$, the $\mathrm{P}$ accumulation further increases to $89 \%$ and thereby the recovery of $\mathrm{P}$ as $\mathrm{CaP}$ granules. However, the aforementioned recovery is largely underestimated because $\mathrm{CaP}$ granules were also taken from the upper part of the sludge bed, where $\mathrm{CaP}$ granules are not fully mature and the $\mathrm{P}$ content is lower. Moreover, issues with the design of the UASB reactor led to scaling of a substantial amount of $\mathrm{P}$ at the inlet system and bottom of both reactors (observed), where sampling was not possible. Thus, in order to decrease the loss of $\mathrm{P}$ by non-recoverable scaling and to enhance $\mathrm{CaP}$ granulation, incoming $\mathrm{P}$ needs to be efficiently mixed in the sludge bed. This will stimulate $\mathrm{CaP}$ granulation due to the higher contact time between $\mathrm{P}$, added $\mathrm{Ca}^{2+}$, inorganic particles, and microorganisms. Consequently, the microbial colonization of these particles is intensified leading to the faster development of $\mathrm{CaP}$ granules. Improved reactor design and scale can overcome these issues, and in that case the recovery potential can increase up to $334 \mathrm{gP}$ person ${ }^{-1}$ year $^{-1}$, producing simultaneously $4.38 \mathrm{~m}^{3} \mathrm{CH}_{4}$ person $^{-1}$ year-1 in a single reactor.

For use of $\mathrm{CaP}$ granules in agriculture or industry a compositional characterization of the final product should be performed to evaluate actual feasibility, safeness, and bioavailability. Nevertheless, Tervahauta et al. (2014c) measured the heavy-metals content in $\mathrm{CaP}$ granules and found that the levels were lower when compared to sewage sludge and bioP sludge and comparable to P rock. Furthermore, Gell et al. (2011) observed that pathogens in struvite produced from BW where below Dutch regulatory levels, and Butkovskyi et al. (2017) assessed the concentration of organic micropollutants in excess sludge from a UASB reactor treating source separated BW, and because of the low values, the authors recommended its use as soil amendment. Based on these preliminary insights, $\mathrm{CaP}$ granules produced during anaerobic treatment of BW are a promising solution as $\mathrm{P}$ recovered product, but further process optimization is required to improve $\mathrm{P}$ recovery efficiency. 


\subsection{Conclusions}

$\mathrm{Ca}^{2+}$ added during the treatment of source separated BW in a UASB reactor (R2) increased accumulation of $\mathrm{P}$ and stimulated formation and growth of $\mathrm{CaP}$ granules, without affecting the treatment performance.

- In both reactors, total COD removal was above $80 \%$ and methanization rate was on average $0.47 \pm 0.19$ gCOD- $\mathrm{CH}_{4} \mathrm{~g}^{-1}$ of $\mathrm{COD}_{\text {Total }}$ in $\mathrm{BW}$.

- According to $\mathrm{PO}_{4}{ }^{3-}$ removal and $\mathrm{Ca} / \mathrm{P}$ molar ratio of retained $\mathrm{Ca}$ and $\mathrm{P}$, addition of $250 \mathrm{mgCa}^{2+} \mathrm{L}^{-1}$ of BW was found to be the optimum.

- $\mathrm{CaP}$ granulation was enhanced by $\mathrm{Ca}^{2+}$ addition. The percentage of particles $>0.4$ $\mathrm{mm}$ diameter (CaP granules) in the sludge bed increased from $63 \%$ in $\mathrm{R} 1$ to $81 \%$ in $\mathrm{R} 2$, after 350 days of operation. Moreover, CaP granules from R2 contained $56 \pm 15$ $\mathrm{mgP} \mathrm{g}^{-1}$ of TSS, while granules from R1 contained only $37 \pm 3 \mathrm{mgP} \mathrm{g}^{-1}$ of TSS.

- The P recovery efficiency was 2.2 times higher in R2 (31\%) than in R1 (14\%). However, the recovery efficiency was hindered by $\mathrm{P}$ scaling at the bottom of both the reactors and retention of solids containing $\mathrm{P}$ in the inlet systems. Considering the total $\mathrm{P}$ in the sludge taken from the sludge bed and in the effluent, the P recovery as $\mathrm{CaP}$ granules increases to $68 \%$ in $\mathrm{R} 2$ and $29 \%$ in R1. 


\section{Chapter 4. The effect of bio-induced increased $\mathrm{pH}$ on the enrichment of calcium phosphate in granules during anaerobic treatment of black water}

J. R. Cunha, T. Tervahauta, R. D. van der Weijden, H. Temmink L. Hernández Leal, G. Zeeman, C. J. N. Buisman

Mechanism for calcium phosphate $(\mathrm{CaP})$ granulation

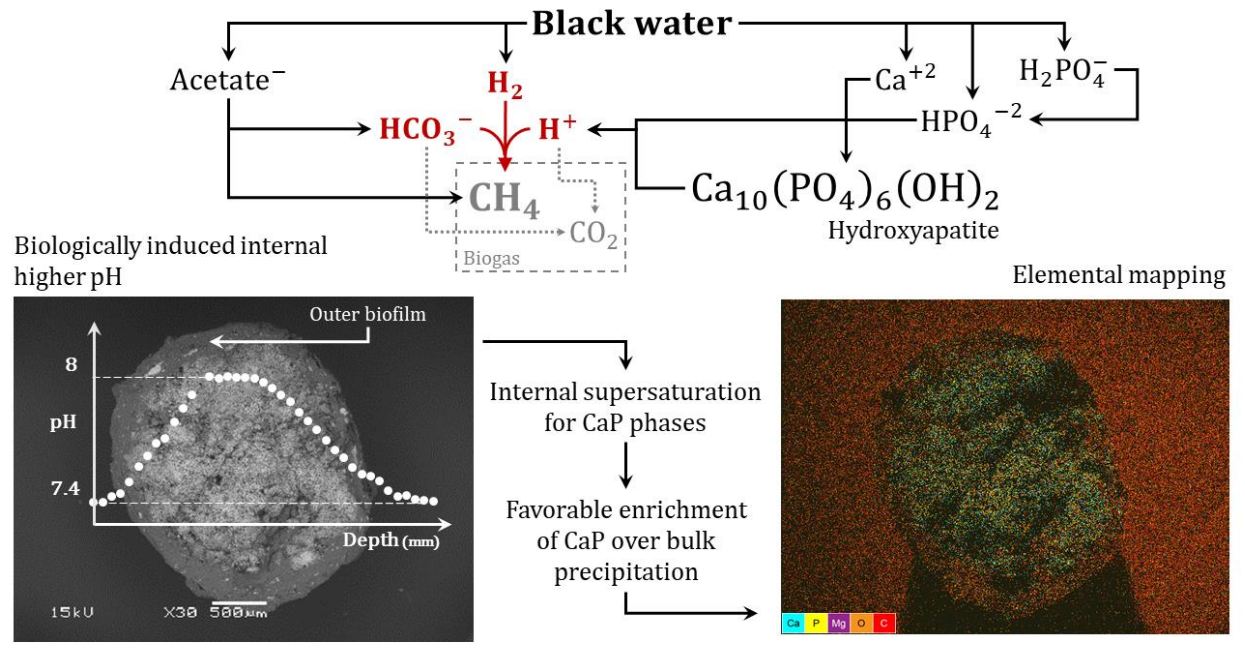

This chapter was published as:

J. R. Cunha, T. Tervahauta, R. D. van der Weijden, H. Temmink L. Hernández Leal, G. Zeeman, C. J. N. Buisman, 2018. The Effect of Bioinduced Increased pH on the Enrichment of Calcium Phosphate in Granules during Anaerobic Treatment of Black Water. Environmental Science \& Technology. 


\begin{abstract}
Simultaneous recovery of calcium phosphate granules (CaP granules) and methane in anaerobic treatment of source separated black water (BW) has been previously demonstrated. The exact mechanism behind the accumulation of calcium phosphate $\left(\mathrm{Ca}_{\mathrm{x}}\left(\mathrm{PO}_{4}\right)_{\mathrm{y}}\right)$ in $\mathrm{CaP}$ granules during black water treatment was investigated in this study by examination of the interface between the outer anaerobic biofilm and the core of $\mathrm{CaP}$ granules. A key factor in this process is the $\mathrm{pH}$ profile in $\mathrm{CaP}$ granules, which increases from the edge (7.4) to the center (7.9). The $\mathrm{pH}$ increase enhances supersaturation for $\mathrm{Ca}_{\mathrm{x}}\left(\mathrm{PO}_{4}\right)_{\mathrm{y}}$ phases, creating internal conditions preferable for $\mathrm{Ca}_{\mathrm{x}}\left(\mathrm{PO}_{4}\right)_{\mathrm{y}}$ precipitation. The $\mathrm{pH}$ profile can be explained by measured bio-conversion of acetate and $\mathrm{H}_{2}, \mathrm{HCO}_{3}{ }^{-}$and $\mathrm{H}^{+}$into $\mathrm{CH}_{4}$ in the outer biofilm and eventually, stripping of $\mathrm{CO}_{2}$ and $\mathrm{CH}_{4}$ (biogas) from the granule. Phosphorus and $\mathrm{Ca}_{\mathrm{x}}\left(\mathrm{PO}_{4}\right)_{\mathrm{y}}$ crystal mass quantity positively correlated with the granule size, which further supports the beneficial role of the internal higher $\mathrm{pH}$ on the maturation and growth of $\mathrm{CaP}$ granules. Additionally, $\mathrm{H}^{+}$released from aqueous phosphate species during $\mathrm{Ca}_{\mathrm{x}}\left(\mathrm{PO}_{4}\right)_{\mathrm{y}}$ crystallization were buffered by internal hydrogenotrophic methanogenesis and stripping of biogas from the granule. These insights into the formation and growth of $\mathrm{CaP}$ granules are important for process optimization, enabling simultaneous $\mathrm{Ca}_{\mathrm{x}}\left(\mathrm{PO}_{4}\right)_{\mathrm{y}}$ and $\mathrm{CH}_{4}$ recovery in a single reactor. Moreover, the biological induction of $\mathrm{Ca}_{\mathrm{x}}\left(\mathrm{PO}_{4}\right)_{\mathrm{y}}$ crystallization by $\mathrm{pH}$ regulation is relevant for understanding of stimulation and control of (bio)crystallization and (bio)mineralization in real environmental conditions.
\end{abstract}




\subsection{Introduction}

Phosphorous (P) is an essential, irreplaceable, and scarce element for humanity (Schröder et al., 2010; U.S. Geological Survey, 2015). Therefore, phosphate $\left(\mathrm{PO}_{4}{ }^{3-}\right)$ recovery from waste streams is an important measure to reduce $\mathrm{P}$ scarcity and to minimize eutrophication, which is associated with $\mathrm{P}$ discharge to natural water bodies.

Current technologies for $\mathrm{P}$ recovery focus on precipitation/crystallization of calcium phosphate species $\left(\mathrm{Ca}_{\mathrm{x}}\left(\mathrm{PO}_{4}\right)_{\mathrm{y}}\right)$ and struvite $\left(\mathrm{MgNH}_{4} \mathrm{PO}_{4} \cdot 6 \mathrm{H}_{2} \mathrm{O}\right)$ from $\mathrm{P}$ enriched side streams of industrial and municipal wastewater treatment plants (Schröder et al., 2010). Struvite can be applied as a slow release fertilizer, but other application options, such as raw material for the phosphorus industry, are limited by the presence of magnesium $(\mathrm{Mg})$ and ammonia (Driver et al., 1999). Alternatively, although $\mathrm{Ca}_{\mathrm{x}}\left(\mathrm{PO}_{4}\right)_{\mathrm{y}}$ has a limited application as a direct fertilizer due to its low solubility in water, it can replace mined $\mathrm{P}$ in both the phosphate and fertilizer industry (Driver et al., 1999; Tervahauta et al., 2014b, 2014c).

Calcium phosphate $(\mathrm{CaP})$ granules were observed for the first time in the sludge bed of a lab scale upflow anaerobic sludge blanket (UASB) reactor, treating vacuum collected black water (BW) without addition of chemicals (Tervahauta et al., 2014c). Yet, although 51 to $56 \%$ was retained in the UASB reactor, only 2 to $8 \%$ of the total incoming $\mathrm{P}$ was found as CaP granules (Cunha et al., 2017; Tervahauta et al., 2014c). An increase of soluble calcium $\left(\mathrm{Ca}^{2+}\right)$ and a decrease of bicarbonate $\left(\mathrm{HCO}_{3}{ }^{-}\right)$in $\mathrm{BW}$ enhanced the accumulation of $\mathrm{P}$ in the UASB reactor $\left(\mathrm{PO}_{4}{ }^{3-}\right.$ removal) (Cunha et al., 2017). By supplementing at least $250 \mathrm{mgCa}^{2+} \mathrm{L}^{-}$ ${ }_{\mathrm{BW}}$ to the UASB reactor, the $\mathrm{P}$ sampled as $\mathrm{CaP}$ granules (>0.4 mm diameter) was enhanced from 2 to $31 \%$ and the P accumulation from 51 to $89 \%$ of the total incoming P (Cunha et al., 2018a). However, a significant fraction of $\mathrm{P}(58 \%)$ was still present as fine particles $(<0.4 \mathrm{~mm}$ diameter), which are unfeasible to recover. Therefore, more understanding of the mechanism behind formation and growth of $\mathrm{CaP}$ granules is essential to stimulate granule formation, enabling simultaneous recovery of $\mathrm{Ca}_{x}\left(\mathrm{PO}_{4}\right)_{y}$ and methane $\left(\mathrm{CH}_{4}\right)$ during anaerobic treatment of BW. Additionally, it can give insights into the application of this process to other wastewater streams, such as manure.

Formation of $\mathrm{Ca}_{\mathrm{x}}\left(\mathrm{PO}_{4}\right)_{\mathrm{y}}$ in the granules does not necessarily start with the thermodynamically most stable phase, but rather the most kinetically accessible phase (Mullin, 2001; Santen, 1984). For instance, formation of hydroxyapatite (HAP) also named apatite, which is the most stable $\mathrm{Ca}_{\mathrm{x}}\left(\mathrm{PO}_{4}\right)_{\mathrm{y}}$ phase, occurs gradually via precursors such as amorphous calcium phosphate (ACP) and octacalcium phosphate (OPC), which are less stable but 
kinetically more favorable (Combes and Rey, 2010; Fosca et al., 2012; Habraken et al., 2013; Kobayashi et al., 2014; Wang et al., 2009). Parameters, such as $\mathrm{pH}$ and $\mathrm{Ca}^{2+}$ and $\mathrm{PO}_{4}{ }^{3-}$ ionic activities, influence the saturation state of $\mathrm{Ca}_{x}\left(\mathrm{PO}_{4}\right)_{\mathrm{y}}$ phases (Song et al., 2002). Since the $\mathrm{pH}$ and $\mathrm{Ca}^{2+}$ and $\mathrm{PO}_{4}{ }^{3-}$ concentrations in $\mathrm{BW}$ are dictated by the dilution factor during $\mathrm{BW}$ collection and by the treatment conditions, the chemical speciation in the interphase between bulk liquid of the reactor and $\mathrm{CaP}$ granule is crucial to understand the enrichment of $\mathrm{Ca}_{\mathrm{x}}\left(\mathrm{PO}_{4}\right)_{\mathrm{y}}$ in the granules. For instance, syntrophic production and consumption of hydrogen $\left(\mathrm{H}_{2}\right)$ by acidifiers, acetogens, and hydrogenotrophic methanogens in the biofilm, which surrounds the $\mathrm{Ca}_{\mathrm{x}}\left(\mathrm{PO}_{4}\right)_{\mathrm{y}}$ core, could induce a local increase in $\mathrm{pH}$, due to the conversion of $\mathrm{H}_{2}$, protons $\left(\mathrm{H}^{+}\right)$ and $\mathrm{HCO}_{3}{ }^{-}$into $\mathrm{CH}_{4}$ (Batstone et al., 2004; Lier et al., 2008). This would favor $\mathrm{Ca}_{\mathrm{x}}\left(\mathrm{PO}_{4}\right)_{\mathrm{y}}$ enrichment of the granules over bulk precipitation.

In this study, $\mathrm{pH}$ in function of granule depth, biological activity, chemical composition, and structural and crystal properties of $\mathrm{CaP}$ granules are experimentally assessed and correlated with the granule size to describe the mechanism behind the desired formation of $\mathrm{Ca}_{\mathrm{x}}\left(\mathrm{PO}_{4}\right)_{\mathrm{y}}$ in $\mathrm{CaP}$ granules over bulk precipitation. Additionally, the biological impact of the outer biofilm on crystallization of HAP is modelled by correlating the biological production and consumption of $\mathrm{HCO}_{3}{ }^{-}$and $\mathrm{H}^{+}$with crystallization of HAP from ACP and OCP phases in $\mathrm{CaP}$ granules.

\subsection{Materials and Methods}

\subsection{1. $\mathrm{pH}$ microelectrode measurements}

The internal $\mathrm{pH}$ profile of $11 \mathrm{CaP}$ granules (> $2.0 \mathrm{~mm}$ diameter) was analyzed with a $25 \mu \mathrm{m}$ microelectrode (Unisense, Denmark) coupled with a reference electrode model RefRM (Unisense, Denmark). The source of granules for the $\mathrm{pH}$ measurements was the lab scale 50 L UASB reactor previously described in Tervahauta et al. (2014c). The reactor operated at $25^{\circ} \mathrm{C}$, at an organic loading rate (OLR) of $0.8 \pm 0.5 \mathrm{kgCOD} \mathrm{m}^{-3} \mathrm{~d}^{-1}$ and hydraulic retention time (HRT) of $11 \pm 3$ days, resulting in an upflow velocity of $0.6 \mathrm{~cm} \mathrm{~h}^{-1}$ and a solids retention time (SRT) of more than 250 days. For the $\mathrm{pH}$ measurements, oxygen-free effluent from the 50 L UASB reactor was used as mobile phase to avoid transport and dissolution of substances from the granule to the mobile phase. Temperature and $\mathrm{pH}$ were controlled at $25 \pm 0.2^{\circ} \mathrm{C}$ and $7.5 \pm 0.02$, respectively. The data was acquired using a $\mathrm{pH}$ meter PHM210 (Radiometer analytical SAS, France), an A/D converter ADC-216 (Unisense, Denmark) and the software Profix 3.10 (Unisense, Denmark), which set the motion of the sensor and logged the data simultaneously. The motion of the sensor was controlled in three axis using a two-dimensional 
stage MT-65 (Phytron Inc., USA) and a motorized micromanipulator MM3M (Unisense, Denmark), which controlled the vertical motion. The calibration was performed using buffers at pH 7 and 9 (VWR International S.A.S., France) at $25^{\circ} \mathrm{C}$.

\subsubsection{Modeling of saturation state of $\mathrm{Ca}_{x}\left(\mathrm{PO}_{4}\right)_{y}$ phases and calcite}

The saturation states of HAP, precursors ACP and OCP, and calcite in function of the local $\mathrm{pH}$ in the granules were calculated using the software Visual MINTEQ version 3.1 (KTH, Sweden). This software uses the Davies equation to calculate activity coefficients (Mullin, 2001), while taking into account the measured chemical composition of $\mathrm{BW}\left(\mathrm{g} \mathrm{L}^{-1}\right): 0.87 \mathrm{NH}_{4}^{+}$, $0.01 \mathrm{Mg}^{2+}, 0.35 \mathrm{Na}^{+}, 0.23 \mathrm{~K}^{+}, 0.5 \times 10^{-3} \mathrm{Fe}^{2+}, 0.05 \mathrm{Ca}^{2+}, 2.36 \mathrm{HCO}_{3}^{-}, 0.46 \mathrm{Cl}^{-}, 0.04 \mathrm{SO}_{4}^{2-}$, $0.7 \times 10^{-3} \mathrm{NO}_{3}{ }^{-}$and $0.16 \mathrm{PO}_{4}{ }^{3-}$. Methods used for the chemical measurements were as described in Cunha et al. (2017). Humic substances, which are known to interact with $\mathrm{Ca}^{2+}$ and $\mathrm{PO}_{4}{ }^{3-}$ (Song et al., 2006a), were included using the complexation model available in the software used; the entering parameters were total dissolved organic carbon (determined by Shimadzu TOC analyzer, $\left.1.3 \mathrm{gC} \mathrm{L}^{-1}\right)$ and dissolved humic acids (136 $\left.\mathrm{mgC} \mathrm{L}^{-1}\right)$. The latter were measured with liquid chromatography - organic carbon detection (LC-OCD, Model 8 with a NDIRdetector Siemens Ultramat $6^{\mathrm{E}}$ and UV and OND detectors Agilent 1260 Infinity). The temperature was set at $25^{\circ} \mathrm{C}$ and $\mathrm{pH}$ was defined according to the obtained $\mathrm{pH}$ depth profile. Then, the saturation state (SI) of each specie (y) was defined by eq. 4.1.

$S I=\log \frac{I A P_{y}}{K_{s p_{y}}}$ Equation 4.1

where $I A P_{y}$ is the ion activity product of the elements in y and $K_{s p_{y}}$ is the solubility product constant of y. For SI $>0 \mathrm{y}$ is supersaturated, for $\mathrm{SI}<0 \mathrm{y}$ is undersaturated and for $\mathrm{SI}=0 \mathrm{y}$ is in apparent equilibrium.

\subsubsection{Specific methanogenic activity tests of CaP granules}

$\mathrm{CaP}$ granules used for the specific methanogenic activity tests were also harvested from the previously mentioned 50 L UASB reactor (Tervahauta et al., 2014c). Granules were separated by density using a polyvinylchloride upflow column, with $1 \mathrm{~cm}$ diameter and $1 \mathrm{~m}$ height. The upflow velocity was $57 \mathrm{~m} \mathrm{~h}^{-1}$ for $6 \mathrm{~min}$, using paper filtered effluent from the same $50 \mathrm{~L}$ UASB reactor as mobile phase. The details of the procedure and chemical and physical characteristics of each fraction are described in Appendix A1. The fraction with highest settling velocity (retained in the column) was then used for the activity tests, which were 
performed at $25^{\circ} \mathrm{C}$ in triplicate according to Angelidaki et al. (2007). Acetate $\left(1 \mathrm{~g} \mathrm{~L}^{-1}\right)$ and $\mathrm{H}_{2} / \mathrm{CO}_{2}$ (1 bar overpressure 80/20) were separately used as substrate to determine the activity of acetoclastic and hydrogenotrophic microorganisms, respectively. Serum bottles $(250 \mathrm{ml})$ were used with a working liquid volume of approximately $125 \mathrm{ml}$ (weight corrections were done for each bottle). The concentration of inoculum was $2.3 \pm 0.5 \mathrm{gVSS} \mathrm{L}^{-1}$. Control (without substrate) and blank (only substrate) tests were performed in duplicate. Macronutrients and micronutrients stock solutions were prepared according to Angelidaki et al. (2007). Sørensen buffer was used to control the operational $\mathrm{pH}$ at 7.4. $\mathrm{CH}_{4}$ production was measured by means of pressure using a manometer GMH 3150-EX (Greisinger electronic, Germany). The composition of headspace gas was determined using gas chromatography (Varian CP4900 Micro GC with two separate column models Mol Sieve $5 \AA$ ALOT (MS5) and PoraPLOT U (PPU)) and the acetate concentration using ion chromatography (Metrohm 761 Compact). Specific methanogenic activity (SMA) rates were calculated for all the tests according to Angelidaki et al. (2007). For the tests with $\mathrm{H}_{2} / \mathrm{CO}_{2}$ the partial pressure of $\mathrm{CH}_{4}\left(\mathrm{P}_{\mathrm{CH}_{4}}\right)$ was quantified according to eq. 4.2 .

$P_{\mathrm{CH}_{4}}=\frac{\Delta P_{\text {Total }}}{n \mathrm{nCH}_{4}-4 n \mathrm{H}_{2}-n \mathrm{CO}_{2}}$

Equation 4.2

where $\Delta P_{\text {Total }}$ is the pressure variation measured with manometer, and $n$ is the partial proportions for anaerobic $\mathrm{CH}_{4}$ production from $\mathrm{H}_{2} / \mathrm{CO}_{2}$, which is assumed 1 for standard temperature and pressure conditions.

\subsubsection{Particle size distribution (PSD), elemental composition, and X-ray diffraction analysis (XRD)}

PSD, elemental analysis, and XRD measurements were performed on CaP granules from two 5 L UASB reactors treating BW (Cunha et al., 2018a). Reactor 1 was a control reactor with the similar operation as the $50 \mathrm{~L}$ UASB reactor used for the micro $\mathrm{pH}$ measurements and methanogenic activity tests. Reactor 2 was used to study the effect of $\mathrm{Ca}^{2+}$ addition on $\mathrm{CaP}$ granulation (Cunha et al., 2018a). Both $5 \mathrm{~L}$ reactors, without and with $\mathrm{Ca}^{2+}$ addition, operated for 460 days at $25{ }^{\circ} \mathrm{C}$ and at an OLR of $1.2 \pm 0.3$ and $1.4 \pm 0.4 \mathrm{kgCOD} \mathrm{m}^{-3} \mathrm{~d}^{-1}$ and HRT of 8 \pm 1 and $7 \pm 1$ days, respectively. These conditions resulted in an upflow velocity of $0.4 \mathrm{~cm} \mathrm{~h}$

${ }^{1}$ for both reactors and SRT of 163 and 186 days for reactor without and with $\mathrm{Ca}^{2+}$ addition, respectively. Sludge samples $(55 \mathrm{ml})$ were sampled on operation days $350,415,436$, and 460 at three different heights from top to bottom $(20,10$, and $5 \mathrm{~cm})$, using a syringe connected to 
a hose with $0.5 \mathrm{~cm}$ diameter. Results are presented as an average of the four sampling occasions.

PSD was analyzed with mesh sizes, dividing particles in the sludge samples as $<0.4$, 0.4 to $0.9,0.9$ to $1.4,1.4$ to $2.0,2.0$ to 2.5 , and $>2.5 \mathrm{~mm}$ diameter. Then, each size fraction was used for elemental and XRD analysis and total and volatile suspended solids (TSS and VSS, respectively) quantification. Elemental composition ( $\mathrm{P}, \mathrm{Ca}$, and $\mathrm{Mg}$ ) was determined by inductively coupled plasma - optical emission spectroscopy (Perkin Elmer Optima 5300 DV ICP-OES) after an $\mathrm{HNO}_{3}$ digestion at $148^{\circ} \mathrm{C}$ for $45 \mathrm{~min}$, using a microwave (MWD Milestone). TSS and VSS were determined by gravimetric standard method (Clesceri et al., 1998).

XRD analyses were performed with a Bruker D8 Advance diffractometer $280 \mathrm{~mm}$ measurement radius using $\mathrm{Cu}$ radiation with Linear PSD $3^{\circ}$ detector opening, divergence slit at $0.58^{\circ}$ and a soller slit at $2.5^{\circ}$. The samples were dried at $105^{\circ} \mathrm{C}$ for $12 \mathrm{~h}$ and ground before the measurements. The software TOPAS (Bruker) based on Rietveld method was used for pattern fitting. Amorphous content was deduced by the degree of crystallinity obtained in the model. The R-weighted pattern was kept below 7 for all models, fitting only the Lorentzian and Gaussian component convolutions of the identified phase structures of hydroxyapatite (COD 9002216 P_63/m) and calcite (COD 9016706 R_-3_c). The morphology and the elemental distribution of $\mathrm{CaP}$ granules were assessed with a scanning electron microscope (SEM) JEOL JSM-6480LV in backscattered detection at $15 \mathrm{kV}$ coupled with NORAN Systems SIX EDX (Thermo Scientific, USA). After sieve separation, a set of $10 \mathrm{CaP}$ granules from the reactor without $\mathrm{Ca}^{2+}$ addition were dried at room temperature and sectioned with a scalp for cross-sectional line scan analysis and only dried for visualization of the outer biofilm and elemental mapping.

\subsubsection{Calculation of mass flows of $\mathrm{HCO}_{3}^{-}, \mathrm{H}^{+}$, and $\mathrm{H}_{2}$ during anaerobic digestion of $\mathrm{BW}$ and HAP crystallization from less stable $\mathrm{Cax}\left(\mathrm{PO}_{4}\right)_{y}$ phases}

Anaerobic digestion of BW was previously modeled by Feng et al. (2006). The model and adopted parameters were then used in this study to calculate the mass flow of $\mathrm{HCO}_{3}{ }^{-}, \mathrm{H}^{+}$, and $\mathrm{H}_{2}$ between the bulk and granule. Presumably, acidification of products from hydrolysis (monosaccharides (MS), amino acids (AA), and long-chain fatty acids (LCFA)) takes place near the granule edge, and acetogenesis and hydrogenotrophic methanogenesis occur only in the outer biofilm of the granule. The assumption is because microbial syntrophy $\left(\mathrm{H}_{2}\right.$ production and consumption) is expected to occur in the outer biofilm due to the proximity between microorganisms (Batstone et al., 2004). Acetate in BW (influent) is converted into $\mathrm{CH}_{4}$ and $\mathrm{HCO}_{3}{ }^{-}$in the bulk of the reactor and propionate and butyrate are only consumed in 
the outer biofilm, along with consumption of produced $\mathrm{H}_{2}$ by hydrogenotrophic methanogens. Equations and parameters used are extensively described in the Appendix A2. The calculation was based on a volumetric unit (L) of BW. Input parameters, which were taken from the monitoring of the $5 \mathrm{~L}$ reactor without $\mathrm{Ca}^{2+}$ addition, were the degraded concentration of suspended and soluble COD (6.9 and $1.6 \mathrm{~g} \mathrm{~L}^{-1}$, respectively). Colloidal COD was included in the suspended COD fraction. Soluble COD was assumed to be a mixture of acetate, propionate, and butyrate $(66 \%, 32 \%$, and $2 \%$, respectively), which corresponded with the measured VFA concentration in BW (Cunha et al., 2018a).

Crystallization of HAP at $\mathrm{pH}$ between 7 and 7.5 and room temperature is occurring via Ca deficient ACP precursors (Habraken et al., 2013). OCP is the intermediate phase, which consists of an agglomeration of ACP complexes mediated by $\mathrm{Ca}^{2+}$ assimilation (Habraken et al., 2013). A complete conversion of ACP into HAP was assumed to estimate the complete release of $\mathrm{H}^{+}$. The fact that $\mathrm{HAP}$ is the thermodynamically most stable $\mathrm{Ca}_{\mathrm{x}}\left(\mathrm{PO}_{4}\right)_{\mathrm{y}}$ phase, and therefore, it is the prevailing crystal phase when the time is not limited, is the basis for this assumption. Moreover, only the accumulated $\mathrm{Ca}^{2+}$ and $\mathrm{PO}_{4}^{3-}$, which was further divided into $\mathrm{H}_{2} \mathrm{PO}_{4}^{-}$and $\mathrm{HPO}_{4}^{2-}$ according to bulk pH (7.5), were considered as input for the calculation. Solid $\mathrm{Ca}$ and $\mathrm{P}$ were not accounted.

\subsection{Results and discussion}

\subsubsection{Internal $\mathrm{pH}$ profile and saturation state of $\mathrm{Ca}_{x}\left(\mathrm{PO}_{4}\right)_{y}$ phases and calcite}

The average internal $\mathrm{pH}$ peak of the measured CaP granules $(\mathrm{n}=11$, Appendix A3) was $7.93 \pm 0.08$ while the mobile phase was kept at $7.5 \pm 0.03$, which corresponded with the bulk $\mathrm{pH}$ in the $50 \mathrm{~L}$ UASB reactor $(7.48 \pm .0 .19)$. As a representative example, the $\mathrm{pH}$ profile of a complete cross-section of a granule is given in Figure 4.1. Considering the soluble chemical composition of raw BW, both precursors ACP and OCP are supersaturated at the higher $\mathrm{pH}$ inside the granule as shown in Figure 4.1. Near the edge and outside of the granule ACP and OCP are undersaturated, indicating that precipitation will not occur. HAP is supersaturated for the entire $\mathrm{pH}$ range measured ( $\mathrm{SI}>6)$, and because of its low solubility $\left(K_{s p}\right.$ $=4.7 \times 10^{-45}$ ), hydroxyapatite is thermodynamically the dominant crystal phase for the $\mathrm{BW}$ chemical matrix. However, at this phase no kinetic predictions about the formation time can be made. This is because HAP nucleation and mineralization time can be influenced by several uncontrolled factors, such as presence organic compounds (proteins and collagen fibers), existing surface, and ionic activity of inhibitors, such as $\mathrm{Mg}$ and carbonate $\left(\mathrm{CO}_{3}{ }^{2-}\right)(\mathrm{Cao}$ and Harris, 2008; Gajjeraman et al., 2007; Kobayashi et al., 2014; Wang et al., 2014). $\mathrm{CaCO}_{3}$ 
(calcite) was supersaturated only within the boundaries of the granule, suggesting that coprecipitation of $\mathrm{CaCO}_{3}$ within the granule is possible. Yet, over time $\mathrm{Ca}_{\mathrm{x}}\left(\mathrm{PO}_{4}\right)_{\mathrm{y}}$ phases prevail due to the thermodynamic equilibrium (lower $K_{s p}$ ), leading to recrystallization of $\mathrm{CaCO}_{3}$ into $\mathrm{Ca}_{\mathrm{x}}\left(\mathrm{PO}_{4}\right)_{\mathrm{y}}$ (Rokidi et al., 2011; Song et al., 2006b). Note that the retention time for solids in the UASB reactor treating BW varied from 163 to > 365 days as previously demonstrated (Cunha et al., 2018a; Graaff et al., 2010). The supersaturation in the granule core, which is induced by the internal higher $\mathrm{pH}$, is crucial for formation of $\mathrm{Ca}_{\mathrm{x}}\left(\mathrm{PO}_{4}\right)_{\mathrm{y}}$ within $\mathrm{CaP}$ granules. Consequently, the formation of $\mathrm{Ca}_{\mathrm{x}}\left(\mathrm{PO}_{4}\right)_{\mathrm{y}}$ fines, which are difficult to separate from the dispersed sludge, is reduced.

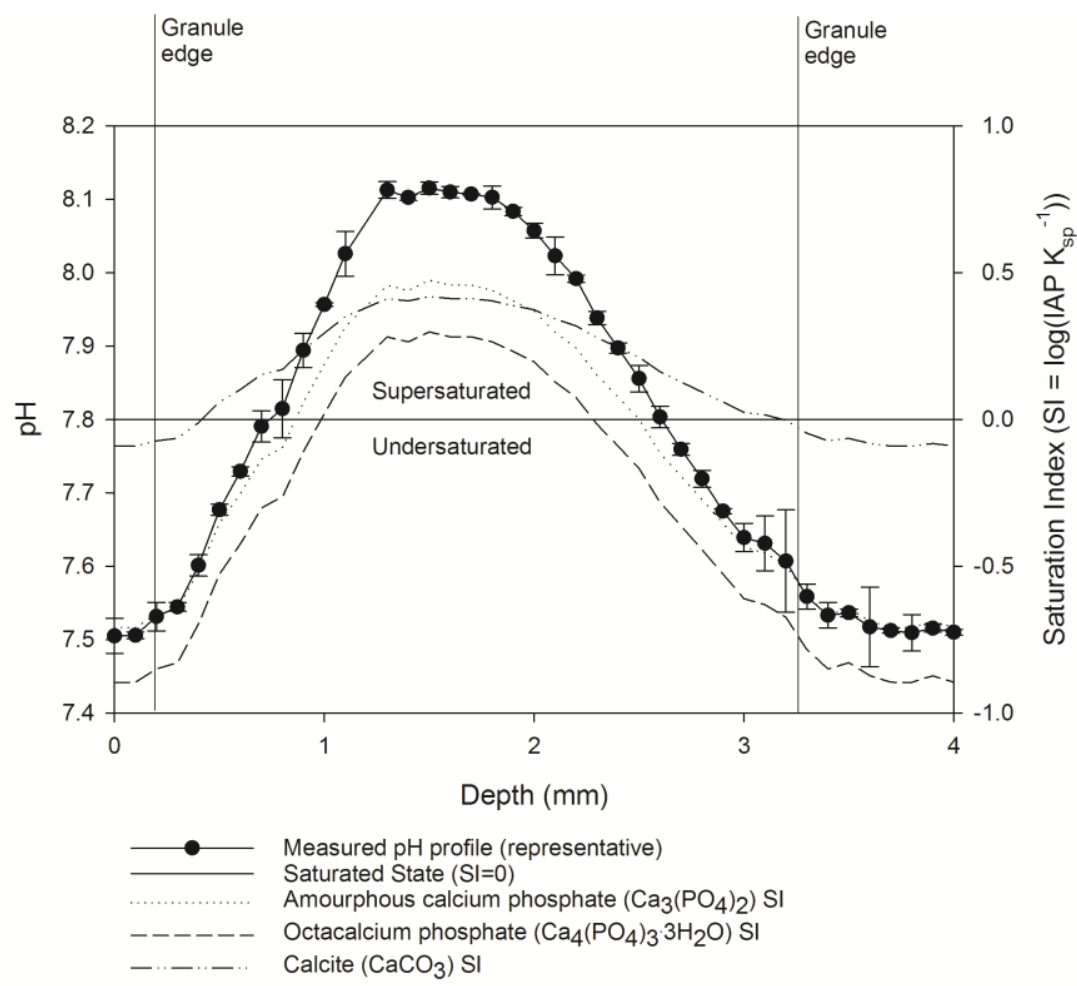

Figure 4.1 Measured $\mathrm{pH}$ profile of a representative $\mathrm{CaP}$ granule $(\sim 3.0 \mathrm{~mm}$ diameter $)$ and saturation state of amorphous calcium phosphate, octacalcium phosphate, and calcite in function of the $\mathrm{pH}$ measured. For $\mathrm{SI}>0$ precipitation can occur (supersaturated), for $\mathrm{SI}<0$ precipitation hardly occurs (undersaturated) and for SI $=0$ each specie is in apparent equilibrium. Half-cross section of the $\mathrm{pH}$ gradient analyzed in 11 granules and respective statistical analysis are in Appendix A3. 


\subsubsection{Methanogenic activity and outer biofilm of CaP granules}

Methanogenic activity tests on $\mathrm{CaP}$ granules showed that acetate and $\mathrm{H}_{2} / \mathrm{CO}_{2}$ were

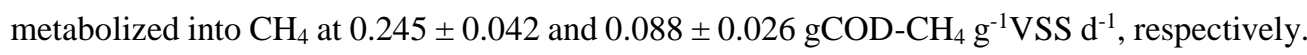
The obtained activity rates are within the range found in existing literature, but lower than the average (Schmidt and Ahring, 1996). The characteristic outer biofilm of CaP granules is determined with SEM in backscattering mode in Figure 4.2b and 4.2c. This allows distinguishing an outer biofilm (darkened) from an inorganic core (lightened). The EDX line scan (Figure 4.2b) analysis shows that the $\mathrm{P}$ and $\mathrm{Ca}$ contents (wt $\%$ ) increased towards the core of the granule (Figure 4.2a). The average P content for the background (from 0 to $150 \mu \mathrm{m}$ ) was $0.3 \mathrm{wt} \%$, for the organic outer layer (from 150 to $260 \mu \mathrm{m}$ and from 360 to $420 \mu \mathrm{m}$ ) was $2.1 \mathrm{wt} \%$ and for the core (from 420 to $800 \mu \mathrm{m}$ ) increased to $10.9 \mathrm{wt} \%$. The P and Ca peak between 260 and $360 \mu \mathrm{m}$ in the line scan corresponds to an isolated $\mathrm{Ca}_{\mathrm{x}}\left(\mathrm{PO}_{4}\right)_{\mathrm{y}}$ particle within the outer biofilm. The $\mathrm{P}$ content of the outer biofilm is higher than the $\mathrm{P}$ content commonly observed for non-limiting $\mathrm{P}$ anaerobic biomass (1.2 wt\%), due to the presence of fine $\mathrm{Ca}_{\mathrm{x}}\left(\mathrm{PO}_{4}\right)_{\mathrm{y}}$ particles (Arne Alphenaar et al., 1993; Langerak et al., 1998). In the core, the $\mathrm{Ca} / \mathrm{P}$ molar ratio is $1.74 \pm 0.63$, which is higher than the theoretical $\mathrm{Ca} / \mathrm{P}$ molar ratio in HAP of 1.67 (Habraken et al., 2013), caused by the presence of $\mathrm{CaCO}_{3}$ as it will be explained later on Figure 4.5. These observations support the hypothesis of local metabolic conversion of acetate and $\mathrm{H}_{2}, \mathrm{HCO}_{3}{ }^{-}$, and $\mathrm{H}^{+}$into $\mathrm{CH}_{4}$, which most probably cause the local higher $\mathrm{pH}$ and formation of $\mathrm{Ca}_{\mathrm{x}}\left(\mathrm{PO}_{4}\right)_{\mathrm{y}}$. 


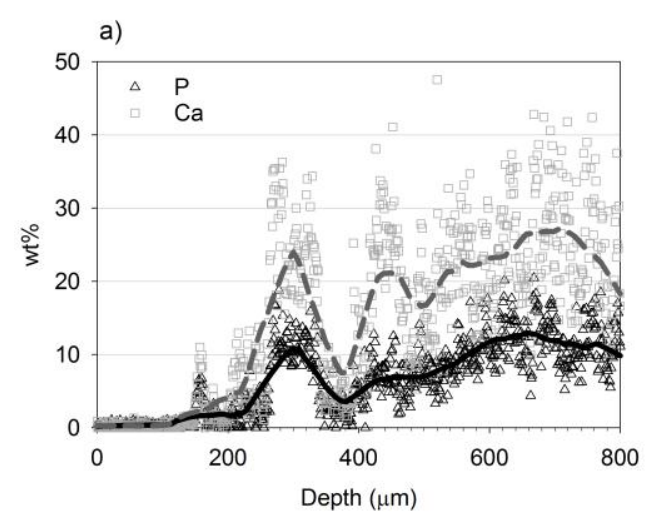

c)

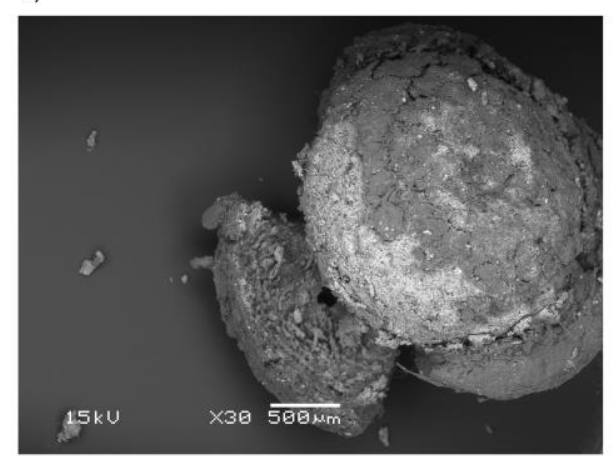

b)

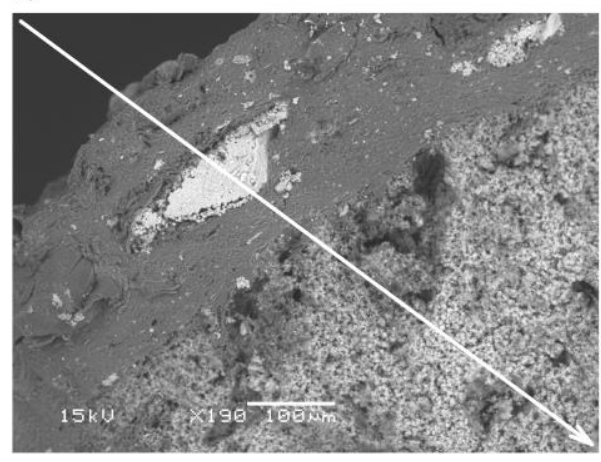

d)

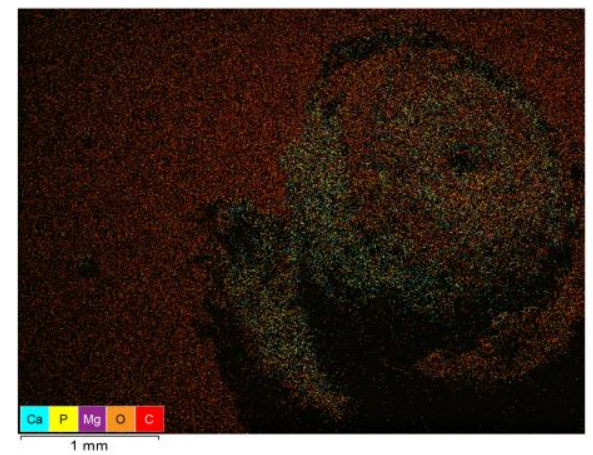

Figure 4.2 Elemental ( $\mathrm{P}$ and $\mathrm{Ca}$ ) line scan (a) of a granule cross section from the $5 \mathrm{~L}$ reactor without $\mathrm{Ca}^{2+}$ addition (b) measured with energy dispersive X-ray (EDX) coupled with scanning electron microscope (SEM). SEM representation of a CaP granule partially detached from the outer biofilm (c) taken from the $5 \mathrm{~L}$ reactor with $\mathrm{Ca}^{2+}$ addition, and its respective elemental distribution measured with $\operatorname{EDX}(\mathrm{d})$.

\subsubsection{Favorable $\mathrm{Cax}_{x}\left(\mathrm{PO}_{4}\right)_{y}$ enrichment of granules over bulk precipitation}

By supplying extra $\mathrm{Ca}^{2+}$ (> $250 \mathrm{mg} \mathrm{L}^{-1}$ BW) the $\mathrm{P}$ content of particles $>0.4 \mathrm{~mm}$ diameter increased from $3.9 \pm 0.5$ to $6.2 \pm 0.9 \mathrm{wt} \%$, whereas for particles $<0.4 \mathrm{~mm}$ diameter the $\mathrm{P}$ content decreased from $2.9 \pm 0.1$ to $2.4 \pm 0.3 \mathrm{wt} \%$ (Figure 4.3). This confirms that $\mathrm{Ca}_{\mathrm{x}}\left(\mathrm{PO}_{4}\right)_{\mathrm{y}}$ enrichment of granules is favored over bulk precipitation, which is in line with the calculated supersaturation for $\mathrm{Ca}_{\mathrm{x}}\left(\mathrm{PO}_{4}\right)_{\mathrm{y}}$ phases in the center of the granule (Figure 4.1). There are two possible mechanisms for $\mathrm{Ca}_{x}\left(\mathrm{PO}_{4}\right)_{y}$ enrichment of granules (Figure 4.4): (1) direct $\mathrm{Ca}_{\mathrm{x}}\left(\mathrm{PO}_{4}\right)_{\mathrm{y}}$ precipitation within existing $\mathrm{CaP}$ granules and (2) formation of $\mathrm{Ca}_{\mathrm{x}}\left(\mathrm{PO}_{4}\right)_{\mathrm{y}}$ in the bulk and subsequent incorporation into the granule. The latter is supported by isolated inorganic particles (white particles) within the outer biofilm as shown in Figure 4.2 and Figure 4.4. By adding extra $\mathrm{Ca}^{2+}$, supersaturation for $\mathrm{Ca}_{x}\left(\mathrm{PO}_{4}\right)_{y}$ phases in the bulk of the reactor is created. However, the SI for $\mathrm{Ca}_{\mathrm{x}}\left(\mathrm{PO}_{4}\right)_{\mathrm{y}}$ phases in the granule will be higher than in 
the bulk due to the higher internal $\mathrm{pH}$. Thus, $\mathrm{Ca}_{\mathrm{x}}\left(\mathrm{PO}_{4}\right)_{\mathrm{y}}$ formed in the bulk, which may be crystalline, amorphous or both, will most likely be incorporated in the biofilm. Then, along with the breakdown of organic material in the biofilm, $\mathrm{Ca}_{\mathrm{x}}\left(\mathrm{PO}_{4}\right)_{\mathrm{y}}$ assemblies travel inwards and merge with the existing $\mathrm{Ca}_{\mathrm{x}}\left(\mathrm{PO}_{4}\right)_{\mathrm{y}}$ core. The agglomeration of $\mathrm{Ca}_{\mathrm{x}}\left(\mathrm{PO}_{4}\right)_{\mathrm{y}}$ assemblies was previously observed, and it occurs via an amorphous interface (Tao et al., 2007; Wang et al., 2009). The decrease in VSS content along the granule growth (Figure 4.3) supports the previous mechanism for $\mathrm{Ca}_{\mathrm{x}}\left(\mathrm{PO}_{4}\right)_{\mathrm{y}}$ enrichment and maturation in $\mathrm{CaP}$ granules.

With $\mathrm{Ca}^{2+}$ addition, a maximum $\mathrm{P}$ content was observed for $\mathrm{CaP}$ granules with a size between 1.4 and $2.5 \mathrm{~mm}$ diameter (Figure 4.3b). Moreover, the VSS content was higher for granules $>2.5 \mathrm{~mm}$ diameter than the latter size range, suggesting that granule maturation was not completely in line with the $\mathrm{CaP}$ granule growth (size) when $\mathrm{Ca}^{2+}$ was added. This indicates the existence of two populations of $\mathrm{CaP}$ granules with similar size, but different $\mathrm{Ca}_{\mathrm{x}}\left(\mathrm{PO}_{4}\right)_{\mathrm{y}}$ content or maturation stages. The reduction in granule size during maturation is most probably related to a decrease in the surface available for attachment of organic material along with the growth of the inorganic core or increase in core density. This was not observed for $\mathrm{CaP}$ granules formed without $\mathrm{Ca}^{2+}$ addition, where a more linear relationship between VSS and $\mathrm{P}$ contents and size was obtained (Figure 4.3a). The difference between these two conditions, with and without $\mathrm{Ca}^{2+}$ addition, is due to the higher concentration granules with higher inorganic content, which is achieved by the higher production and growth of $\mathrm{CaP}$ granules when $\mathrm{Ca}^{2+}$ is added. 

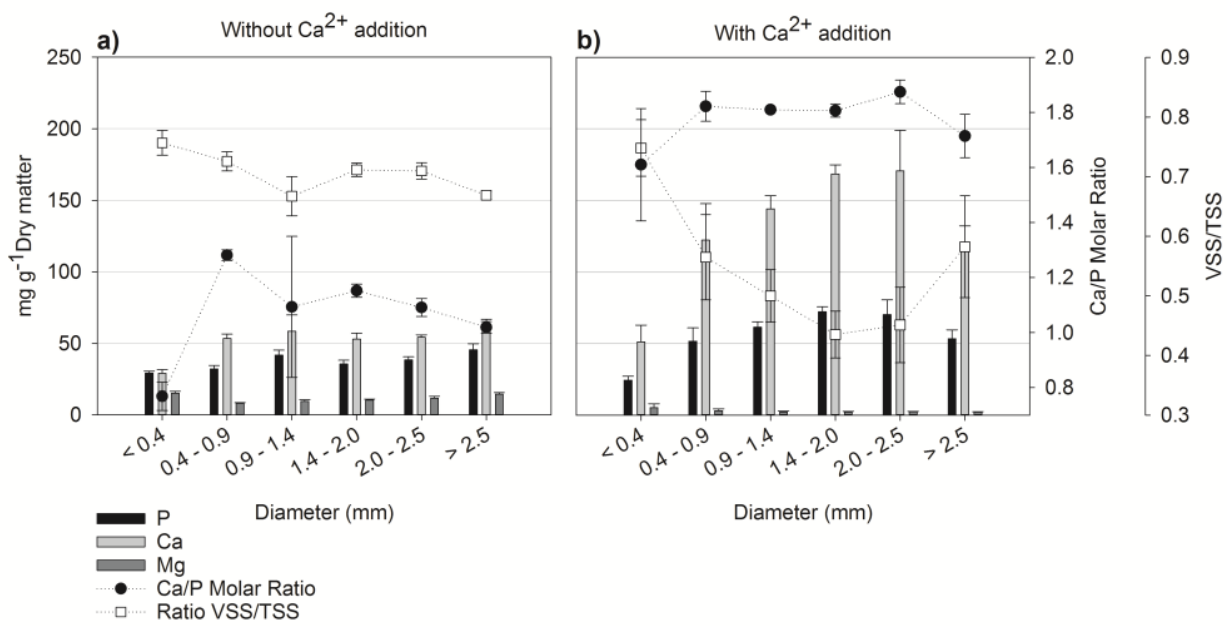

Diameter (mm)

Figure 4.3 Correlation between size (diameter) and $\mathrm{P}, \mathrm{Ca}, \mathrm{Mg}$, and VSS (as the ratio VSS/TSS) contents and the $\mathrm{Ca} / \mathrm{P}$ molar ratio for each size fraction of sludge taken from the 5 $\mathrm{L}$ reactors, without $\mathrm{Ca}^{2+}$ addition (a) and with $\mathrm{Ca}^{2+}$ addition (b). Values are averages of four samples taken on operation days 350, 415, 436, and 460 .

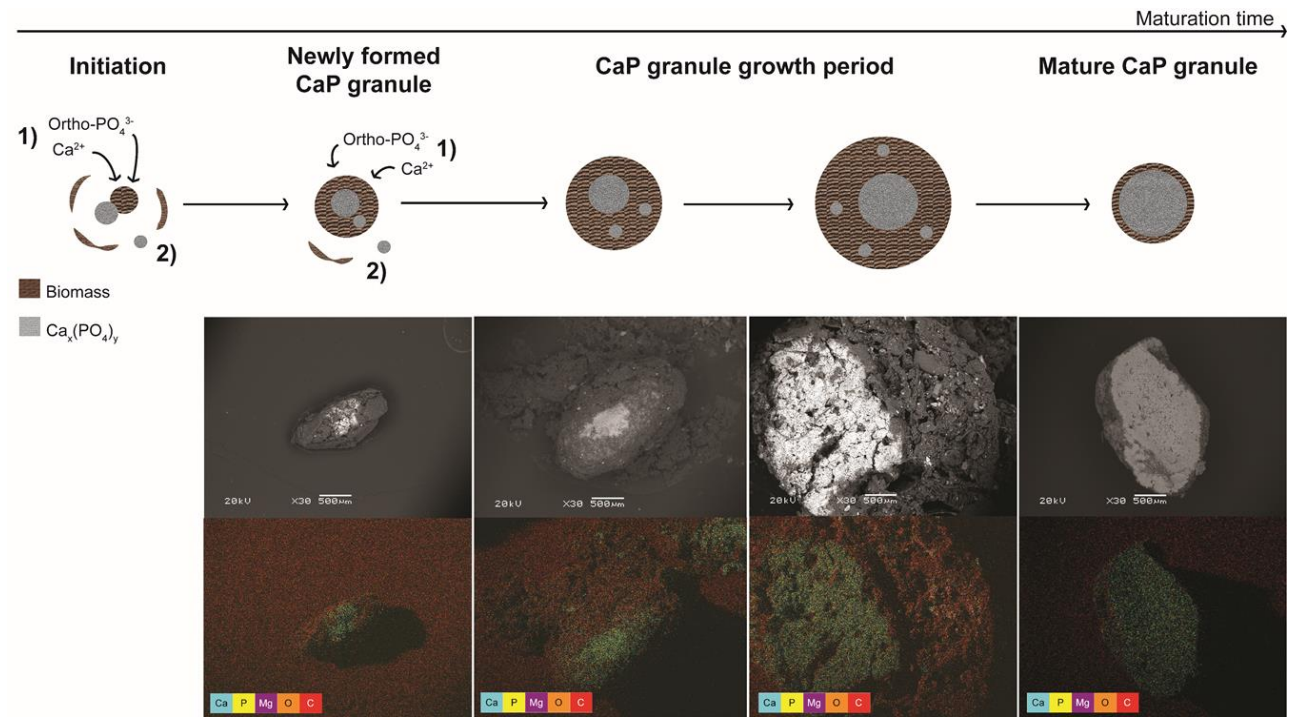

Figure 4.4 Proposed mechanism for $\mathrm{CaP}$ granulation supported by SEM and SEM-EDX images of $\mathrm{CaP}$ granules. 


\subsubsection{Crystal properties of CaP granules}

Crystal phase identification showed that HAP and calcite were the most prominent phases in all particle sizes for both conditions, with and without $\mathrm{Ca}^{2+}$ addition (Figure 4.5). The broadening and overlap of the HAP peaks between positions ( $\left.2^{\circ} \mathrm{Theta}\right) 30$ and 35 are most likely due to the presence of HAP nanocrystals (Bian et al., 2012; Scardi et al., 2011). The percentage of HAP was always higher than calcite, and a positive correlation between the particle size and HAP content was observed (Figure 4.5). By adding $\mathrm{Ca}^{2+}$, the crystal percentage of $\mathrm{HAP}$ in $\mathrm{CaP}$ granules (> $0.4 \mathrm{~mm}$ diameter) increased from $8.4 \pm 2.0$ to $21.5 \pm$ $5.4 \%$, while the crystal percentage of calcite remained relatively constant $(2.0 \pm 0.3 \%$ without $\mathrm{Ca}^{2+}$ addition and $2.3 \pm 0.6 \%$ with $\mathrm{Ca}^{2+}$ addition). Moreover, the amorphous content of $\mathrm{CaP}$ granules decreased with the $\mathrm{Ca}^{2+}$ addition from $89.6 \pm 2.1$ to $76.2 \pm 5.9 \%$. Additionally, pattern fitting results showed that crystallite size for HAP and calcite were on average $5.5 \pm 0.5$ and $31.4 \pm 11.3 \mathrm{~nm}$ for all granule size fractions and those are similar with the crystallite sizes reported in previous studies (Cölfen and Antonietti, 1998; Feng et al., 2000; Habraken et al., 2013; Wang et al., 2012). The increase in crystallite size of HAP in CaP granules was minor by adding $\mathrm{Ca}^{2+}$ (from $5.1 \pm 0.4$ to $5.8 \pm 0.2 \mathrm{~nm}$ ). Thus, $\mathrm{Ca}^{2+}$ addition increased the $\mathrm{Ca}_{\mathrm{x}}\left(\mathrm{PO}_{4}\right)_{\mathrm{y}}$ content in $\mathrm{CaP}$ granules by enhancing the formation and agglomeration of nanocrystals. According to existing literature, the crystallization of HAP nanocrystals is mediated by ACP complexes, which facilitate the $\mathrm{H}^{+}$release from $\mathrm{H}_{2} \mathrm{PO}_{4}{ }^{-}$and $\mathrm{HPO}_{4}{ }^{2-}$ by binding $\mathrm{Ca}^{2+}\left(\mathrm{Ca}^{2+}\right.$ $\mathrm{HPO}_{4}{ }^{2-}$ ), evolving to the intermediate phase OCP (Kobayashi et al., 2014; Wang et al., 2009). Then, the growth of the HAP nanocrystal is occurring via OCP dissolution and recrystallization of OCP lattice ions into the pre-nanocrystal until the maximum size, which is based on the ordered structure of the surface (P_63/m) for the solution conditions, being reached (Bian et al., 2012; Fosca et al., 2012; Kobayashi et al., 2014). Then, the HAP nanocrystals ( $5 \mathrm{~nm})$ agglomerate through the formation of a hydration layer (Bian et al., 2012; Wang et al., 2009). The hydration layer dictates the overall particle size of the HAP conglomerate and the reactivity with cationic (e.g., $\mathrm{Ca}^{2+}$ and $\mathrm{Mg}^{2+}$ ), inorganic (e.g., $\mathrm{CaCO}_{3}$ ), and organic compounds (e.g., collagen fibers) (Bar-Yosef Ofir et al., 2004; Bertinetti et al., 2009; Gajjeraman et al., 2007; Habraken et al., 2013). Moreover, the exact composition and structural properties of the hydration layer are dependent on the water-pore composition of the granules (Bertinetti et al., 2009; Bian et al., 2012). Therefore, the internal conditions in CaP granules play a crucial role not only in the $\mathrm{Ca}_{\mathrm{x}}\left(\mathrm{PO}_{4}\right)_{\mathrm{y}}$ formation but also on the agglomeration mechanism. 
1)

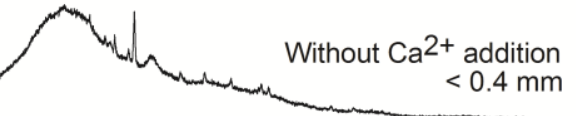

2)

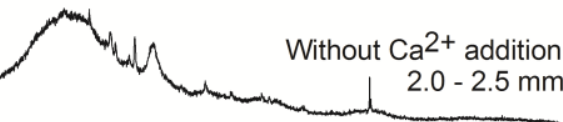

3)

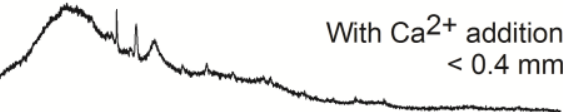

4)

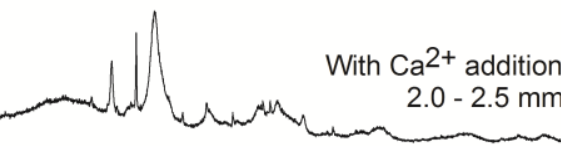

5)

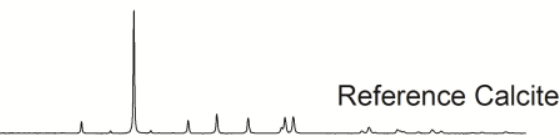

6)

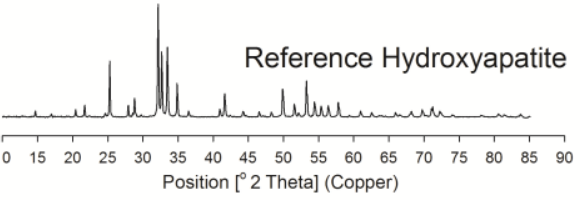

a) Amorphous

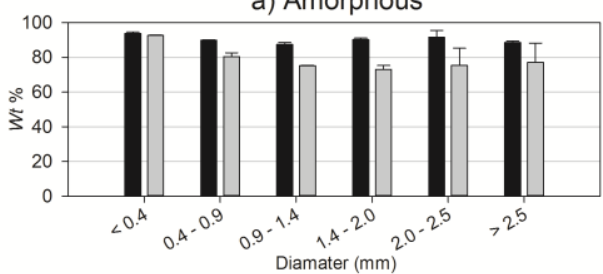

b) Crystal HAP

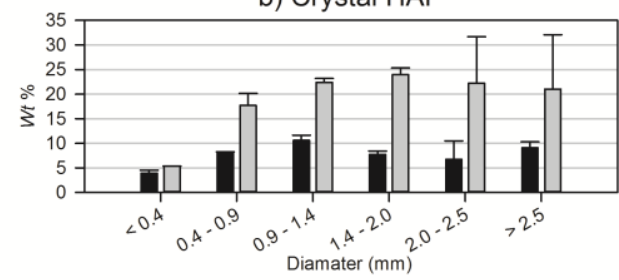

c) Crystal Calcite

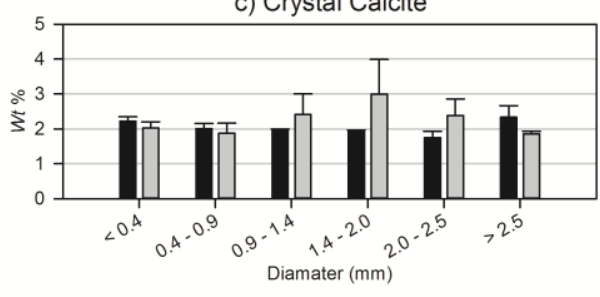

Without $\mathrm{Ca}^{2+}$ addition
With $\mathrm{Ca}^{2+}$ addition

Figure 4.5 XRD scans of particles $<0.4 \mathrm{~mm}$ diameter and $\mathrm{CaP}$ granules with diameter between 2 and $2.5 \mathrm{~mm}$ from sludge samples taken from the reactor without $\mathrm{Ca}^{2+}$ addition (1 and 2) and the reactor with $\mathrm{Ca}^{2+}$ addition ( 3 and 4), and XRD scans of Hydroxyapatite (HAP) and Calcite (5 and 6). Weight percentage of amorphous (a), crystal HAP (b), and crystal calcite (c), according to Rietveld pattern fitting.

\subsubsection{Effect of $\mathrm{HCO}_{3}^{-}, \mathrm{H}^{+}$, and $\mathrm{H}_{2}$ flows on $\mathrm{CaP}$ granulation}

Conversion of $\mathrm{H}^{+}, \mathrm{HCO}_{3}{ }^{-}$, and $\mathrm{H}_{2}$ into $\mathrm{CH}_{4}$ in the outer biofilm, mass transfer limitations created by the outer biofilm, and eventually, stripping of $\mathrm{CO}_{2}\left(\mathrm{H}_{2} \mathrm{CO}_{3}\right)$ and $\mathrm{CH}_{4}$ gases from the granule induce an internal environment in $\mathrm{CaP}$ granules with reduced $\mathrm{H}^{+}$ionic activity (higher $\mathrm{pH}$ ) and lower $\mathrm{CO}_{3}{ }^{2-}$ concentration. This is crucial for $\mathrm{Ca}_{\mathrm{x}}\left(\mathrm{PO}_{4}\right)_{\mathrm{y}}$ enrichment in the granules, because $\mathrm{H}^{+}$released from the deprotonation of $\mathrm{H}_{2} \mathrm{PO}_{4}{ }^{-}$and $\mathrm{HPO}_{4}{ }^{2-}$ and from the recrystallization of ACP and OCP into HAP need to be locally buffered, in order to maintain the favorable conditions for $\mathrm{Ca}_{\mathrm{x}}\left(\mathrm{PO}_{4}\right)_{\mathrm{y}}$ formation along with the granule maturation (Combes and Rey, 2010; Habraken et al., 2013; Wang et al., 2009). 
In Figure 4.6 the estimated formation and consumption of $\mathrm{HCO}_{3}^{-}, \mathrm{H}^{+}$, and $\mathrm{H}_{2}$ throughout the anaerobic digestion of BW is shown. Acetate in BW is readily converted into $\mathrm{CH}_{4}$ and $\mathrm{HCO}_{3}{ }^{-}$by disperse sludge in the bulk at the bottom of the reactor. The calculated production of $\mathrm{HCO}_{3}{ }^{-}$from acetate degradation in the bulk $(16 \mathrm{mM})$ is similar to the experimentally measured increase of $\mathrm{HCO}_{3}{ }^{-}$during the treatment $(13 \pm 5 \mathrm{mM})$ in the reactor without $\mathrm{Ca}^{2+}$ addition. In the reactor with $\mathrm{Ca}^{2+}$ addition, the measured increase of $\mathrm{HCO}_{3}{ }^{-}$was only $6 \pm 2 \mathrm{mM}$, most likely because of higher $\mathrm{CaCO}_{3}$ formation in the bulk and granules.

Disintegration/hydrolysis of biodegradable organic solids and colloids yield MS, AA, and LCFA which are further acidified in the interface between bulk and granule. This is because $\mathrm{H}_{2}$ produced during acidogenesis is rapidly consumed by $\mathrm{H}_{2}$ consuming organisms during hydrogenotrophic methanogenesis in the outer edge of the granular structure to enable further degradation of propionate and butyrate, as previously proposed by Batstone et al. (2004) for anaerobic granules treating brewery wastewater. The anaerobic degradation of propionate and butyrate is only exergonic when $\mathrm{H}_{2}$ partial pressure is lower than $10^{-4} \mathrm{~atm}$, and since $\mathrm{H}_{2}$ is a by-product of propionate and butyrate acetogenic reactions, hydrogenotrophic methanogenesis must be locally associated with acetogenesis (Hori et al., 2006; Lier et al., 2008). Thus, degradation of propionate and butyrate, which are products of acidogenesis, was assumed to undergo within the outer biofilm of $\mathrm{CaP}$ granules. Yet, hydrogenotrophic methanogenesis is also possible with disperse sludge due to the low upflow velocity applied $\left(<1 \mathrm{~cm} \mathrm{~h}^{-1}\right)$, enabling conditions for exchange of substrates. $\mathrm{H}_{2}$ was never detected in the biogas produced in the two $5 \mathrm{~L}$ reactors and the $50 \mathrm{~L}$ reactor used in this study.

The calculated concentration of $\mathrm{H}^{+}$during acidogenesis of MS, AA, and LCFA was $57.1 \mathrm{mM}$ (Figure 4.6). The consumption of $\mathrm{H}^{+}$produced during acidogenesis was assumed to take place within the outer biofilm of the granule. Yet, part of the $\mathrm{H}^{+}$may be responsible for the decrease in bulk pH from $7.94 \pm 0.33(\mathrm{n}=58)$ in the influent BW to $7.44 \pm 0.04(\mathrm{n}=70)$. Nevertheless, the uptake of $\mathrm{H}^{+}$during hydrogenotrophic methanogenesis and the buffering capacity by the $\mathrm{HCO}_{3}{ }^{-}$produced during internal acetoclastic methanogenesis is sufficient to neutralize the total produced $\mathrm{H}^{+}$, including the $\mathrm{H}^{+}$released during the formation and recrystallization of $\mathrm{Ca}_{\mathrm{x}}\left(\mathrm{PO}_{4}\right)_{\mathrm{y}}$ phases. The role of $\mathrm{H}^{+}$concentration in the local $\mathrm{pH}$ was previously reported by Garcia-Robledo et al. (2016), who by supplying $\mathrm{H}_{2}$ in an anaerobic membrane bioreactor treating sieved $(2 \mathrm{~mm})$ cattle manure observed an increase in $\mathrm{pH}$ from 7 to 9.5 in the biofilm $\left(0.5 \mu \mathrm{m}\right.$ depth). This was due to a depletion of $\mathrm{CO}_{2}\left(\mathrm{H}^{+}\right.$and $\left.\mathrm{HCO}_{3}{ }^{-}\right)$during hydrogenotrophic methanogenesis. Batstone et al. (2004) modeled the degradation of MS, AA, LCFA, volatile fatty acids (VFA), and $\mathrm{H}_{2}$ along the biofilm depth in an anaerobic granule and 
also obtained an increasing $\mathrm{pH}$ gradient from the edge towards the center. This is in line with the internal $\mathrm{pH}$ gradient measured in $\mathrm{CaP}$ granules (Figure 4.1). Therefore, the favorable internal conditions for $\mathrm{Ca}_{\mathrm{x}}\left(\mathrm{PO}_{4}\right)_{\mathrm{y}}$ formation are indirectly biologically induced.

For the formation of HAP only the soluble $\mathrm{P}$ (Total Ortho- $\mathrm{PO}_{4}{ }^{3-}$ ) retained in the reactors without $(0.3 \mathrm{mM})$ and with $(1.2 \mathrm{mM}) \mathrm{Ca}^{2+}$ addition was considered (Figure 4.6). Solid $\mathrm{P}$, which represented $68 \%$ of the total $\mathrm{P}$ in $\mathrm{BW}$, was mostly accumulated in the reactor in both situations, with and without $\mathrm{Ca}^{2+}$ addition. Solid $\mathrm{P}$ was in the form of organically bound $\mathrm{P}$, struvite, and $\mathrm{Ca}_{\mathrm{x}}\left(\mathrm{PO}_{4}\right)_{\mathrm{y}}$ (Graaff et al., 2011a). Organically bound $\mathrm{P}$ is hydrolyzed and solubilized as $\mathrm{PO}_{4}{ }^{3-}$, which leaves the reactor in the effluent or is used for $\mathrm{Ca}_{\mathrm{x}}\left(\mathrm{PO}_{4}\right)_{\mathrm{y}}$ formation within the granules, depending on the $\mathrm{Ca}^{2+}$ concentration (Cunha et al., 2017). Because of the $\mathrm{HCO}_{3}{ }^{-}$surplus, $\mathrm{CaCO}_{3}$ is likely formed in the outer biofilm (up to $11 \mathrm{wt} \%$, derived from the $\mathrm{Ca} / \mathrm{P}$ molar ratio presented in Figure 4.3). However, $\mathrm{CaCO}_{3}$ dissolves over time due to the thermodynamic advantage of HAP formation (Song et al., 2006b). Traces of struvite were also observed in the outer biofilm, representing up to $12 \mathrm{wt} \%$ of the granules without $\mathrm{Ca}^{2+}$ addition, but they dissolve when $\mathrm{Ca}^{2+}$ is added, representing less than $2.5 \mathrm{wt} \%$ (Figure 4.3).

The time evolution of a $\mathrm{CaP}$ granule is a complex process involving three main aspects: (1) recrystallization and maturation of crystals and amorphous complexes from different species $\left(\mathrm{Ca}_{\mathrm{x}}\left(\mathrm{PO}_{4}\right)_{\mathrm{y}}, \mathrm{CaCO}_{3}\right.$, and struvite); (2) microbial growth and decay in the outer biofilm, and (3) anaerobic degradation of organics in BW. In this study, these three aspects were correlated based on the anaerobic treatment of a volumetric unit (L) of BW, without a kinetic reference (Figure 4.6). For a kinetic correlation, a single granule imbedded in BW could be individually monitored in a batch system over a defined period. Then, biological and crystallographic parameters could be correlated with time, providing more insights into the organic and inorganic growth rates in $\mathrm{CaP}$ granules. 


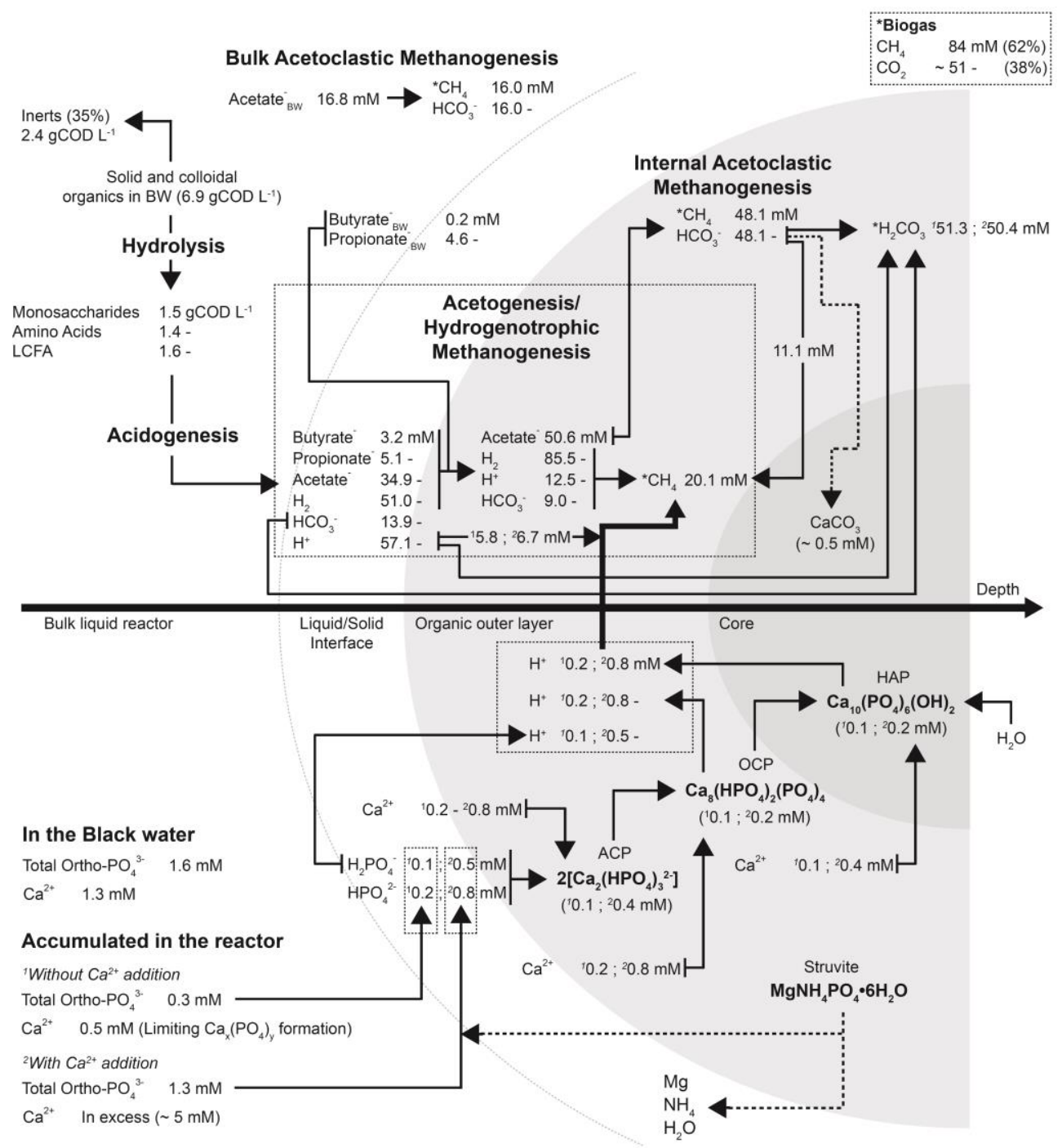

Figure 4.6 Mass balance between the biological degradation of solid and soluble organic compounds in BW (above depth axis) and the formation of HAP from less stable phases (ACP and $\mathrm{OCP}$ ), considering the accumulated Ortho- $\mathrm{PO}_{4}{ }^{3-}$ and $\mathrm{Ca}^{2+}$ in the two situations, without and with $\mathrm{Ca}^{2+}$ addition (below depth axis). The calculation was based on a volumetric unit (L) of BW. Operational parameters were obtained from the treatment performance without and with $\mathrm{Ca}^{2+}$ addition (Cunha et al., 2018a). Degradation and yield constants were adapted from Feng et al. (2006). 


\subsubsection{Harvesting strategy based on growth mechanism}

Supplementation of $\mathrm{Ca}^{2+}\left(250 \mathrm{mg} \mathrm{L}^{-1}{ }_{\mathrm{BW}}\right)$ during BW treatment increased the retention the total incoming P in the UASB reactor (89\%), but only $31 \%$ was harvested as CaP granules (Cunha et al., 2018a). This is because CaP granules were harvested at different heights without any selection factor for mature $\mathrm{CaP}$ granules. The harvested $\mathrm{CaP}$ granules $(>0.4 \mathrm{~mm}$ diameter) contained on average $6.2 \mathrm{wt} \% \mathrm{P}$ (Figure 4.3), but the granule core showed a P content of 10.9 wt \% (Figure 4.2). This is because the harvesting of non-mature granules (>0.4 mm diameter) implies the removal of a higher amount of organic matter. Thus, the harvesting strategy is crucial for the recovery efficiency and overall process feasibility. Based on the growth mechanism (Figure 4.3 and Figure 4.4), larger granules are not necessarily fully mature. Therefore, size separation in the reactor is not ideal. The density of HAP varies from 2 to $6 \mathrm{~g}$ $\mathrm{cm}^{-3}$, depending on the formation conditions. Because a much lower density was observed for dispersed sludge $\left(1.4 \mathrm{~g} \mathrm{~cm}^{-3}\right)$, internal liquid or gas upflow mixing could be used to enhance the concentration of denser granules at the bottom part. Simultaneously, lifted granules and fine inorganic particles would have higher contact with biomass, $\mathrm{PO}_{4}{ }^{3-}$, and $\mathrm{Ca}^{2+}$, stimulating the further growth of younger granules and the formation of the initial nuclei; note that with the UASB configuration used in this study the liquid flows in a vertical plug-flow mode. Additionally, attention should be given to the bulk pH, which should be kept below 7.8 to avoid unwanted $\mathrm{Ca}_{\mathrm{x}}\left(\mathrm{PO}_{4}\right)_{\mathrm{y}}$ precipitation in the bulk of the reactor. 
Chapter 5. Bulk pH and carbon source are key factors for calcium phosphate bio granulation

J. R. Cunha, S. Morais, J. C. Silva, R. D. van der Weijden, L. Hernández Leal, G. Zeeman, C. J. N. Buisman
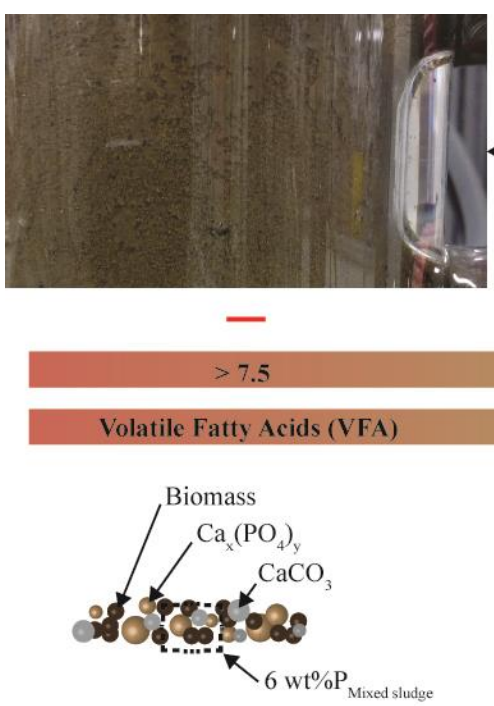

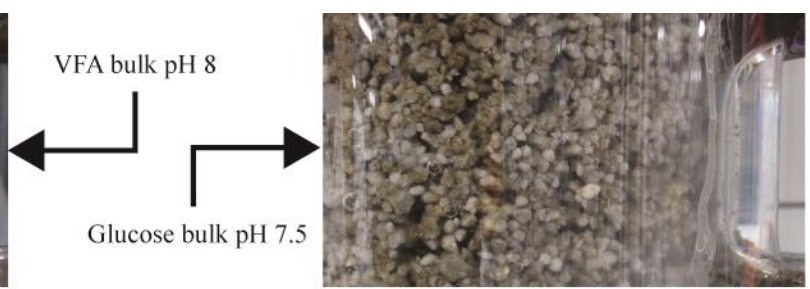

$+$

This chapter was submitted as:

J. R. Cunha, S. Morais, J. C. Silva, R. D. van der Weijden, L. Hernández Leal, G. Zeeman, C. J. N. Buisman, 2018. Bulk pH and carbon source are key factors for calcium phosphate bio granulation. 


\begin{abstract}
Recovery of calcium phosphate granules (CaP granules) in anaerobic treatment of high-strength wastewater is an opportunity to reduce the impact of several environmental problems, such as natural phosphorus $(\mathrm{P})$ scarcity, the geographic imbalances of $\mathrm{P}$ reserves, and eutrophication. Formation of $\mathrm{CaP}$ granules was previously observed in the anaerobic treatment of source separated black water (BW) using a UASB reactor and enhanced by $\mathrm{Ca}^{2+}$ addition. Yet, the required operating conditions and influent composition for $\mathrm{CaP}$ bio granulation are still unknown. In this study, we have experimentally demonstrated that the carbon source and bulk $\mathrm{pH}$ are crucial parameters for formation and growth of $\mathrm{CaP}$ granules in a UASB reactor, operating at relatively low upflow velocity $\left(<1 \mathrm{~cm} \mathrm{~h}^{-1}\right)$. Degradation of glucose yielded sufficient biomass (microbial cells and extracellular biopolymers) to cover crystal and amorphous calcium phosphate $\left(\mathrm{Ca}_{\mathrm{x}}\left(\mathrm{PO}_{4}\right)_{\mathrm{y}}\right)$, forming $\mathrm{CaP}$ granules. Influent only containing volatile fatty acids (VFA) as carbon source did not generate $\mathrm{CaP}$ granules. Moreover, bulk pH between 7.0 and 7.5 was crucial for the enrichment of $\mathrm{Ca}_{\mathrm{x}}\left(\mathrm{PO}_{4}\right)_{\mathrm{y}}$ in the granules over bulk precipitation. Bulk pH 8 reduced the $\mathrm{Ca}_{\mathrm{x}}\left(\mathrm{PO}_{4}\right)_{\mathrm{y}}$ enrichment in granules > $1.4 \mathrm{~mm}$ diameter from 9 to $5 \mathrm{wt} \% \mathrm{P}$. Moreover, for bulk $\mathrm{pH} 7.5$ co-precipitation of $\mathrm{CaCO}_{3}$ with $\mathrm{Ca}_{\mathrm{x}}\left(\mathrm{PO}_{4}\right)_{\mathrm{y}}$ was reduced. $\mathrm{CaP}$ granules $(>1.4 \mathrm{~mm}$ diameter) formed during anaerobic treatment of glucose at bulk pH 7.5 in this study had a high degree of similarity with BW CaP granules (1.4 to $2.0 \mathrm{~mm}$ diameter), according to elemental composition, organic content, and X-ray diffraction analysis (XRD).
\end{abstract}




\subsection{Introduction}

Recovery of calcium phosphate granules (CaP granules) in anaerobic treatment of high-strength wastewater is a potential opportunity to decrease the human footprint on the natural phosphorus $(\mathrm{P})$ cycle by reducing the impact of phosphate rock scarcity and geographic imbalances on the global food security and preventing eutrophication from $\mathrm{P}$ discharge in natural water courses.

Formation of CaP granules was firstly observed by Tervahauta et al. (2014c) in an upflow anaerobic sludge blanket (UASB) reactor treating vacuum collected black water (BW). Without the addition of chemicals, 2 to $8 \%$ of the total $\mathrm{P}$ in $\mathrm{BW}$ was found as $\mathrm{CaP}$ granules (Cunha et al., 2017; Tervahauta et al., 2014c). By adding $\mathrm{Ca}^{2+}$, the percentage of $\mathrm{P}$ harvested as $\mathrm{CaP}$ granules from the total $\mathrm{P}$ fed increased to $31 \%$, but $89 \%$ of the total $\mathrm{P}$ fed accumulated in the sludge bed of the UASB reactor (Cunha et al., 2018a). Precipitation of calcium phosphate species $\left(\mathrm{Ca}_{\mathrm{x}}\left(\mathrm{PO}_{4}\right)_{\mathrm{y}}\right)$ within existing granules over bulk precipitation is favored by a local micro-environment with an increasing $\mathrm{pH}$ gradient from 7.5 at the edge to 8 in the granule center (Cunha et al., 2018b). Moreover, Batstone et al. (2004), who modeled substrate degradation kinetics in anaerobic granular sludge using ADM1 model, observed that generally, the $\mathrm{pH}$ increased from the edge to the granule center. Conversion of organic acids into $\mathrm{CH}_{4}$ and $\mathrm{CO}_{2}$ (acetoclastic methanogenesis) and $\mathrm{CO}_{2}$ plus $\mathrm{H}_{2}$ into $\mathrm{CH}_{4}$ (hydrogenotrophic methanogenesis) in the granule caused the pH gradient (Batstone et al., 2004; Cunha et al., 2018b). However, the internal $\mathrm{pH}$ varied with type and concentration of organic substrates in bulk liquid (wastewater) (Batstone et al., 2004). Therefore, in this study, the effect of bulk pH and substrate type on $\mathrm{CaP}$ bio granulation is separately investigated to reveal the required conditions for formation and growth of $\mathrm{CaP}$ granules.

In BW, only $32 \%$ of the total COD is soluble, of which 50 to $70 \%$ are volatile fatty acids (VFA) rapidly degraded at the bottom of the reactor (Graaff et al., 2010). Thus, because $68 \%$ of the COD is in the solid and colloidal form, hydrolysis of solids is the rate-limiting step ( $k_{h}$ of $0.1 \mathrm{~d}^{-1}$ ) for anaerobic treatment of BW (Graaff et al., 2010). Consequently, acidogenesis, acetogenesis, and methanogenesis are kinetically dependent on the hydrolysis (Tchobanoglous et al., 2004). Liu et al. (2004) reported that substrate limitation (stress) is one of the major causes for granulation by stimulating the production of extracellular biopolymers or extracellular polymeric substances (EPS). The agglomeration of biopolymers and microorganisms creates a structural matrix where microbial syntrophy (exchange of byproducts) is kinetically favored (Stams, 1994). Schmidt and Ahring (1994), who determined 
the concentration and composition of biopolymers in granular sludge, measured lower concentration of polysaccharides and proteins in the biopolymer matrix in granular sludge fed with VFA when compared to granular sludge fed with wastewater from sugar factory, paper mill, and fish meal process. This is an indication that the yield of biopolymers is enhanced when hydrolysis and/or acidogenesis are required process steps during the substrate conversion to $\mathrm{CH}_{4}$. Thus, during anaerobic treatment of $\mathrm{BW}$, formed biopolymers are likely stimulating the formation of $\mathrm{CaP}$ granules by enhancing agglomeration of organic and $\mathrm{Ca}_{\mathrm{x}}\left(\mathrm{PO}_{4}\right)_{\mathrm{y}}$ particles, which is the foundation for CaP bio granulation (Cunha et al., 2018b). Addition of extra $\mathrm{Ca}^{2+}$ (250 $\mathrm{mg} \mathrm{L}^{-1}$ ) increased the production of $\mathrm{CaP}$ granules by directly increasing the formation and growth of $\mathrm{Ca}_{\mathrm{x}}\left(\mathrm{PO}_{4}\right)_{\mathrm{y}}$ particles (Cunha et al., 2018a). Additionally, the formation of bridges between $\mathrm{Ca}^{2+}$ and negatively charged biopolymers and microbial cells may have stimulated formation of $\mathrm{CaP}$ granules by strengthening the organic matrix, and consequently, the capture and agglomeration of $\mathrm{Ca}_{\mathrm{x}}\left(\mathrm{PO}_{4}\right)_{\mathrm{y}}$ particles (Zhou et al., 2006).

The effect of bulk $\mathrm{pH}$, substrate degradation (high and low energy $\left(\Delta \mathrm{G}^{\mathrm{o}}\right)$ ), and production of biopolymers on $\mathrm{CaP}$ bio granulation was investigated by monitoring four labscale UASB reactors. Two bioreactors were fed with glucose at bulk pH 7.5 and 8 to stimulate biopolymer production. The other two bioreactors were fed with VFA mixture at bulk pH 7.5 and 8 to limit biopolymer production. Simulated BW matrix (anions and cations) was fed to all bioreactors. Then, treatment performance was determined by measuring COD and $\mathrm{PO}_{4}{ }^{3-}$ removals and $\mathrm{CH}_{4}$ production. $\mathrm{CaP}$ bio granulation was assessed by particle size, elemental ( $\mathrm{P}, \mathrm{Ca}$, and $\mathrm{Mg}$ ), and $\mathrm{X}$-ray diffraction (XRD) analyses.

\subsection{Materials and Methods}

\subsubsection{Experimental set-up and influent composition}

Four $2 \mathrm{~L}$ lab-scale UASB reactors (G1, G2, V1, and V2) were operated at $25^{\circ} \mathrm{C}$ with an aimed HRT of 4 days and organic loading rate (OLR) of $1 \mathrm{gCOD} \mathrm{L}^{-1} \mathrm{~d}^{-1}$. The inoculum (1 $\mathrm{L}$ for each reactor) was obtained from a full-scale UASB reactor treating BW (Graaf and Hell, 2014) and sieved before inoculation to remove particles $>0.4 \mathrm{~mm}$ diameter. Applied substrates were glucose for G1 and G2 and VFA mixture $(60 \%, 20 \%$, and 20\% of acetate, propionate, and butyrate in a COD base, respectively) for V1 and V2. The experimental setup is schematically presented in Appendix B1. Nutrients were mixed with the substrates just before the reactor inlet. $\mathrm{Ca}^{2+}$ and $\mathrm{Mg}^{2+}$ were separately fed to each reactor to avoid precipitation in the inlet system. The flow of the substrate, nutrients, and $\mathrm{Ca}^{2+}$ and $\mathrm{Mg}^{2+}$ solutions was 0.24 (48\%), $0.24(48 \%)$, and $0.02(4 \%) \mathrm{L} \mathrm{d}^{-1}$, respectively. The substrate solution for G1 and G2 
contained $7.8 \mathrm{~g} \mathrm{~L}^{-1}$ of $\mathrm{C}_{6} \mathrm{H}_{12} \mathrm{O}_{6}$ (glucose) and for $\mathrm{V} 1$ and $\mathrm{V} 2$ contained $6.4 \mathrm{~g} \mathrm{~L}^{-1}$ of $\mathrm{C}_{2} \mathrm{H}_{3} \mathrm{NaO}_{2}$, $1.1 \mathrm{ml} \mathrm{L}^{-1}$ of $\mathrm{C}_{3} \mathrm{H}_{6} \mathrm{O}_{2}$, and $0.9 \mathrm{ml} \mathrm{L}^{-1}$ of $\mathrm{C}_{4} \mathrm{H}_{8} \mathrm{O}_{2}$. The nutrients solution, which was prepared according to the soluble chemical composition of BW (Graaff et al., 2010), was equal for all reactors and contained $\left(\mathrm{g} \mathrm{L}^{-1}\right): 2.3 \mathrm{KHCO}_{3}, 1.5 \mathrm{Na}_{3} \mathrm{PO}_{4} \cdot 12 \mathrm{H}_{2} \mathrm{O}, 8.6 \mathrm{NH}_{4} \mathrm{Cl}, 3.8 \mathrm{NaHCO}_{3}$, and $0.2\left(\mathrm{NH}_{4}\right)_{2} \mathrm{SO}_{4}$. Additionally, trace elementals were added according to Angelidaki et al. (2007). The $\mathrm{Ca}^{2+}$ and $\mathrm{Mg}^{2+}$ solution contained $\left(\mathrm{g} \mathrm{L}^{-1}\right): 21.4 \mathrm{CaCl}_{2} \cdot 2 \mathrm{H}_{2} \mathrm{O}$ and $0.8 \mathrm{MgCl}_{2} \cdot 6 \mathrm{H}_{2} \mathrm{O}$. $\mathrm{Ca}^{2+}$ was added to obtain a $\mathrm{Ca}^{2+} / \mathrm{PO}_{4}{ }^{3-}$ molar ratio of 3 , which is sufficient for $\mathrm{P}$ removal as previously observed by Seckler et al. (1996). The chemical composition of each solution was experimentally determined. Nutrients and $\mathrm{Ca}^{2+}$ and $\mathrm{Mg}^{2+}$ solutions were assessed for $\mathrm{pH}$, elements ( $\mathrm{P}, \mathrm{Ca}, \mathrm{Mg}, \mathrm{Na}, \mathrm{K}$, and $\mathrm{S})$, anions $\left(\mathrm{PO}_{4}{ }^{3-}, \mathrm{Cl}^{-}\right.$, and $\left.\mathrm{SO}_{4}{ }^{2-}\right)$, cations $\left(\mathrm{NH}_{4}{ }^{+}, \mathrm{Ca}^{2+}\right.$ and $\mathrm{Mg}^{2+}$ ), total organic carbon (TOC), and inorganic carbon (IC). The later was combined with $\mathrm{pH}$, which was measured right after sampling, using a pre-calibrated Endress+Hauser sensor, to calculate the $\mathrm{HCO}_{3}{ }^{-}$concentration according to eq. 5.1.

$\left[\mathrm{HCO}_{3}^{-}\right]=\frac{I C \cdot\left(10^{-p H}\right) \cdot k_{a 1}}{\left(\left(10^{-p H}\right)\right)^{2}+\left(10^{-p H}\right) \cdot k_{a 1}+k_{a 1} \cdot k_{a 2}}$

Equation 5.1

where $k_{a 1}=4.467 \times 10^{-7} \mathrm{~mol} \mathrm{~L}^{-1}$ and $k_{a 2}=4.477 \times 10^{-11} \mathrm{~mol} \mathrm{~L}^{-1}\left(25^{\circ} \mathrm{C}\right)$ (Tchobanoglous et al., 2004).

Substrate solutions were assessed for total and soluble COD, VFA (acetate, propionate, and butyrate), and TOC. Effluent of each reactor was weekly assessed for soluble and total elements, anions, cations, TOC, IC, total and soluble COD, and VFA. The bulk pH for each reactor was measured on top of each reactor using Endress+Hauser sensors precalibrated with pH 7 and 9 buffer solutions (VWR Chemicals, the Netherlands). The bulk pH was controlled manually by dosing $\mathrm{NaOH}$ in each substrate solution.

\subsubsection{Physical and chemical analyses}

Concentration of elements was measured with inductively coupled plasma - optical emission spectrometry (Perkin Elmer Optima 5300 DV ICP-OES). For soluble elements, samples were pre-filtered with $0.45 \mu \mathrm{m}$ membrane Cronus filter PTFE. For total elementals unfiltered samples were digested with $\mathrm{HNO}_{3}$ in combination with microwave-induced heating (MWD Milestone) at $148^{\circ} \mathrm{C}$ during 45 min prior ICP-OES analysis. Concentration of anions, cations, and VFA was measured with ion chromatography (Metrohm 761 Compact) using 
membrane filtered samples. TOC and IC concentrations were measured with a Shimadzu TOC analyzer after membrane filtration.

\subsubsection{Particle size distribution analysis}

Sludge $(60 \mathrm{ml})$ was sampled at $5 \mathrm{~cm}$ from the bottom of each reactor on days 56,89 , $126,152,195$, and 217 of operation. Then, particle size distribution was measured through a sequential separation using mesh sieves with pore size 1.4, 0.9, and $0.4 \mathrm{~mm}$. Collected particle fractions had $>1.4,1.4$ to $0.9,0.9$ to 0.4 , and $<0.4 \mathrm{~mm}$ diameter. The total suspended solids (TSS) and volatile suspended solids (VSS) concentrations and elemental composition were determined for each size fraction (except samples of day 152). TSS and VSS were assessed with the standard gravimetric method (Clesceri et al., 1998), and elemental composition was measured using ICP-OES on solid samples after drying at $105^{\circ} \mathrm{C}$ for at least $12 \mathrm{~h}$ and digested with $\mathrm{HNO}_{3}$ as aforementioned. Particle fractions from day 56 were also assessed with X-ray diffraction (XRD) analysis, using a Bruker D8 Advance diffractometer with $\mathrm{Cu}$ radiation. The samples were dried at $105^{\circ} \mathrm{C}$ for $12 \mathrm{~h}$ and ground before the measurements. Granule samples (> $1.4 \mathrm{~mm}$ diameter), which were taken from G1 after the operation period (217 days), were subjected to a prefixation step using glutaraldehyde (2.5\%) as described in Ismail et al. (2010). Then, they were visualized with scanning electron microscope (JEOL JSM-6480LV) for structural analysis.

\subsubsection{Extraction and quantification of biopolymers}

Extraction of soluble, loose, and bound biopolymers was performed through a sequential extraction using a cation exchange resin (CER) as described in Frølund et al. (1996) for each reactor. Loose and bound biopolymers were quantified for all particle size fractions of reactors G1 and G2 and only for particles $<0.4 \mathrm{~mm}$ diameter for V1 and V2. Soluble biopolymers, or bulk biopolymers, were measured in the supernatant after separation of particles $<0.4 \mathrm{~mm}$ diameter. Each size fraction was resuspended in $100 \mathrm{mM} \mathrm{NaCl}$ solution and stirred at $1000 \mathrm{rpm}$ for 3 hours to extract the loose fraction of biopolymers. After centrifugation $(12000 \mathrm{~g}$ for $10 \mathrm{~min}$ ), the loose biopolymers were then quantified in the supernatant. The pellet was resuspended once more with the $\mathrm{NaCl}$ solution and mixed with pre-washed CER at a concentration of $70 \mathrm{~g} \mathrm{~g}^{-1}$ VSS. CER was washed with 1x PBS buffer solution for 1 hour while stirring at $300 \mathrm{rpm}$. The mixture of resuspended pellet and CER was stirred for 2 hours at $600 \mathrm{rpm}$ at $4^{\circ} \mathrm{C}$ to extract the bound fraction of biopolymers and subsequently centrifuged ( $12000 \mathrm{~g}$ for $15 \mathrm{~min}$ ). The bound biopolymers were then measured in the supernatant. 
The quantification of biopolymers was determined in a carbon basis by liquid chromatography - organic carbon detection (LC-OCD, Model 8 with an NDIR-detector Siemens Ultramat $6^{\mathrm{E}}$ and UV and OND detector Agilent 1260 Infinity) after a $0.22 \mu \mathrm{m}$ membrane filtration (Thermo Scientific Nalgene filter) to remove microbial cells and debris. Because of the high $\mathrm{Ca}^{2+}$ concentration, the biopolymers quantification could be significantly underestimated by the formation of complexes which are removed from the liquid by the 0.22 $\mu \mathrm{m}$ filtration step. Thus, TOC concentration was determined without the filtration step to evaluate the effect of $\mathrm{Ca}^{2+}$. Then, the colloidal carbon is estimated by subtracting the dissolved organic carbon (DOC) obtained by LC-OCD from the TOC.

\subsection{Results and discussion}

\subsubsection{Treatment performance and operational conditions}

Stabilization of bulk $\mathrm{pH}$ and methanization was reached after 100 days of operation for all reactors (Appendix B2). Thus, steady state is assumed between operation days 100 and 200. In Table 5.1, the bulk $\mathrm{pH}$ and the key performance parameters for the treatment efficiency of each reactor are then presented for the steady state period. The effect of the carbon source and bulk $\mathrm{pH}$ on the $\mathrm{CaP}$ bio granulation are separately presented and discussed in the following sub-sections.

Regarding COD removal, the increase in bulk $\mathrm{pH}$ for $\mathrm{G} 2$ and $\mathrm{V} 2$ resulted in a reduction in the overall COD removal and methanization rate when compared to G1 and V1. This can be explained by $\mathrm{pH}$ inhibition on the degradation of glucose and VFA (Boone and Xun, 1987; Duarte and Anderson, 1982; Fang and Liu, 2002; Fukuzaki et al., 1990; Zoetemeyer et al., 1982). In G2 and V2, a higher percentage of COD was missing in the mass balance ( $28 \%$ and $18 \%$, respectively) compared to G1 and V1 (7\% and $1 \%$, respectively). A foam layer above the gas-liquid-solid separator was observed for G2 and V2, which likely contributed to the COD removal but not to the methanization. The relatively high concentration of VFA leaving the reactors G2 and V2 could have acted as a surfactant, inducing the foam formation (Ganidi et al., 2009). According to the COD balance, the estimated concentration of COD trapped on top of G2 and V2 was 1.1 and $0.6 \mathrm{gCOD} \mathrm{L}^{-1}$, respectively. For V1 the $\mathrm{pH}$ stabilized at $7.7 \pm 0.1$, although $\mathrm{NaOH}$ dosing $(6 \mathrm{mM})$ stopped after 140 days of operation.

For $\mathrm{PO}_{4}{ }^{3-}$ removal, the increase in bulk $\mathrm{pH}$ for $\mathrm{G} 2(\mathrm{pH}$ 8.1) and $\mathrm{V} 2(\mathrm{pH}$ 8.2) did not significantly affect the $\mathrm{PO}_{4}{ }^{3-}$ removal efficiency, when compared to G1 and V1 (Table 5.1). Thus, bulk pH 7.5 (G1) is sufficient to decrease the $\mathrm{PO}_{4}{ }^{3-}$ concentration from $64 \pm 15 \mathrm{mgP} \mathrm{L}$ ${ }^{1}$ in the influent to $7.6 \pm 1.4 \mathrm{mgP} \mathrm{L}^{-1}$ in the effluent ( $88 \%$ removal), when $\mathrm{Ca}^{2+}$ was added at 
$\mathrm{Ca}^{2+} / \mathrm{PO}_{4}{ }^{3-}$ molar ratio of 2.7. At bulk pH 7, the $\mathrm{PO}_{4}{ }^{3-}$ removal for both $\mathrm{G} 1$ and $\mathrm{G} 2$ decreased to $70 \%$, and it decreased further for bulk $\mathrm{pH}$ lower than 7.0. This is explained by a reduction in the ionic activity of $\mathrm{HPO}_{4}{ }^{2-}$ and an increase of $\mathrm{H}_{2} \mathrm{PO}_{4}^{-}(\mathrm{pKa}=7.21)$, diminishing $\mathrm{Ca}_{\mathrm{x}}\left(\mathrm{PO}_{4}\right)_{y}$ formation (Habraken et al., 2013).

Removal of $\mathrm{Ca}^{2+}$ was proportional to bulk pH (Table 5.1), indicating that $\mathrm{Ca}^{2+}$ removal was not influenced by the substrate use, but rather dependent on the bulk $\mathrm{pH}$. For G1, the $\mathrm{Ca}^{2+} / \mathrm{PO}_{4}{ }^{3-}$ molar ratio of accumulated and/or precipitated $\mathrm{Ca}^{2+}$ and $\mathrm{PO}_{4}{ }^{3-}$ was $1.6 \pm 0.9$, while for G2, V1, and V2, the $\mathrm{Ca}^{2+} / \mathrm{PO}_{4}{ }^{3-}$ molar ratio was $2.56 \pm 1.34,2.17 \pm 1.02$, and $2.97 \pm$ 1.38 , respectively. The $\mathrm{Ca}^{2+} / \mathrm{PO}_{4}{ }^{3-}$ molar ratio obtained for $\mathrm{G} 1$ was close to the theoretical $\mathrm{Ca}^{2+} / \mathrm{PO}_{4}{ }^{3-}$ molar ratio of hydroxyapatite (HAP, 1.67). For G2, V1, and V2 the $\mathrm{Ca}^{2+} / \mathrm{PO}_{4}{ }^{3-}$ molar ratio was greater than the reference value for HAP, indicating that part of the accumulated $\mathrm{Ca}^{2+}$ was used for other proposes than $\mathrm{Ca}_{\mathrm{x}}\left(\mathrm{PO}_{4}\right)_{\mathrm{y}}$ formation. For V1 (bulk $\mathrm{pH}$ 7.7), the higher $\mathrm{HCO}_{3}{ }^{-}$concentration when compared to $\mathrm{G} 1$ (Table 5.1) induced a higher coprecipitation of $\mathrm{CaCO}_{3}$, although the bulk $\mathrm{pH}$ was lower than in $\mathrm{V} 2$; the higher $\mathrm{HCO}_{3}$ concentration in V1 originated from the higher degree of neutralized VFA degradation in the reactor. 
Table 5.1 Key parameters of operational conditions and treatment performance for each reactor between operation days 100 and 200 .

\begin{tabular}{|c|c|c|c|c|c|c|c|c|c|}
\hline & & G1 & & G2 & & V1 & & $\mathrm{V} 2$ & \\
\hline & Unit & Glucose & $s d$ & Glucose & $s d$ & VFA & $s d$ & VFA & $S d$ \\
\hline Bulk pH & & 7.49 & 0.10 & 8.06 & 0.39 & 7.72 & 0.08 & 8.20 & 0.16 \\
\hline OLR & $\mathrm{gCOD} \mathrm{L}^{-1} \mathrm{~d}^{-1}$ & 1.0 & 0.1 & 1.0 & 0.1 & 0.8 & 0.1 & 0.9 & 0.1 \\
\hline Total COD influent & $\mathrm{gCOD} \mathrm{L}^{-1}$ & 3.9 & 0.1 & 3.7 & 0.4 & 3.4 & 0.3 & 3.4 & 0.3 \\
\hline HRT & days & 3.9 & 0.5 & 4.1 & 1.0 & 4.1 & 0.7 & 3.8 & 0.4 \\
\hline Total COD removal & $\%$ & 88 & 2 & 76 & 9 & 95 & 6 & 73 & 14 \\
\hline VFA removal & $\%$ & - & - & - & - & 93 & 8 & 65 & 19 \\
\hline VFA effluent & $\mathrm{gCOD} \mathrm{L}^{-1}$ & 0.04 & 0.02 & 0.25 & 0.19 & 0.06 & 0.04 & $\mathbf{0 . 5 3}$ & 0.25 \\
\hline Solid COD effluent & $\mathrm{gCOD} \mathrm{L}^{-1}$ & $\mathbf{0 . 0 7}$ & 0.05 & 0.33 & 0.3 & 0.05 & 0.06 & 0.15 & 0.08 \\
\hline Methanization & gCOD-CH $4 \mathrm{~g}^{-1} \mathrm{COD}-\mathrm{Inf}$ & 0.7 & 0.1 & 0.4 & 0.2 & 0.9 & 0.1 & 0.5 & 0.1 \\
\hline${ }^{\mathrm{b}}$ Sludge production (measured) & gCOD-VSS g ${ }^{-1}$ COD-Inf & 0.11 & & 0.08 & & 0.04 & & 0.05 & \\
\hline${ }^{\mathrm{c}}$ Sludge production (calculated) & $\mathrm{gCOD} \mathrm{g}^{-1} \mathrm{COD}-\mathrm{Inf}$ & 0.18 & & 0.36 & & 0.05 & & 0.23 & \\
\hline COD missing & $\%$ & 7 & & 28 & & 1 & & 18 & \\
\hline $\mathrm{PO}_{4}^{3-}$ influent loading & $\mathrm{mg} \mathrm{d}^{-1}$ & 104 & 29 & 101 & 36 & 100 & 29 & 111 & 37 \\
\hline $\mathrm{Ca}^{2+}$ influent loading & $\mathrm{mg} \mathrm{d}^{-1}$ & 119 & 10 & 112 & 18 & 113 & 10 & 120 & 16 \\
\hline Influent $n\left[\mathrm{Ca}^{2+}\right] / n\left[\mathrm{PO}_{4}{ }^{3-}\right]$ & $\mathrm{mol} / \mathrm{mol}$ & 2.7 & 1.0 & 2.6 & 1.4 & 2.7 & 1.0 & 2.6 & 1.2 \\
\hline $\mathrm{PO}_{4}^{3-}$ removal & $\%$ & 88 & 2 & 91 & 5 & 90 & 3 & 85 & 5 \\
\hline $\mathrm{Ca}^{2+}$ removal & $\%$ & 45 & 11 & 77 & 10 & 64 & 7 & 82 & 5 \\
\hline Inorganic Carbon effluent & $\operatorname{mgC~L} \mathrm{L}^{-1}$ & 545 & 50 & 602 & 83 & 620 & 46 & 572 & 97 \\
\hline $\mathrm{HCO}_{3}^{-}$effluent & $\mathrm{g} \mathrm{L}^{-1}$ & 2.58 & 0.24 & 2.99 & 0.41 & 3.01 & 0.22 & 2.84 & 0.48 \\
\hline
\end{tabular}

${ }^{\mathrm{b}}$ Considering the VSS concentration at the bottom (sampling location) and sludge bed height

${ }^{c}$ Accumulated COD based on COD-Inf minus COD-Eff and COD-CH 4 


\subsubsection{The role of the carbon source in CaP bio granulation}

Granule formation was observed for both reactors fed with glucose (G1 and G2) after 89 days of operation (Figure 5.1). The concentration of particles $>0.4 \mathrm{~mm}$ diameter between operation days 126 and 217 was $47 \pm 5$ and $42 \pm 4$ gTSS L $^{-1}$ sludge for G1 and G2, respectively, representing $79 \pm 7 \%$ and $62 \pm 6 \%$ of the total TSS concentration. The lower percentage of granules in $\mathrm{G} 2$ compared to $\mathrm{G} 1$ can be explained by the higher level of $\mathrm{Ca}^{2+}$ precipitation in the bulk, which led to the formation of fine particles $(<0.4 \mathrm{~mm}$ diameter $)$, decreasing the percentage of particles $>0.4 \mathrm{~mm}$ diameter. Note, that the average concentration of particles $>$ $0.4 \mathrm{~mm}$ diameter in G1 and G2 for the same period was similar. For the reactors fed with VFA mixture (V1 and V2) granule formation was nearly absent; the percentage of particles $>0.4$ mm diameter between operation days 126 and 217 was $12 \pm 7 \%\left(10 \pm 8 \mathrm{gTSS} \mathrm{L}^{-1}\right.$ Sludge $)$ and 8 $\pm 4 \%\left(7 \pm 4 \mathrm{gTSS} \mathrm{L}^{-1}\right.$ Sludge $)$ for $\mathrm{V} 1$ and $\mathrm{V} 2$, respectively. Thus, the bulk $\mathrm{pH}$ had a trivial effect on the granule formation when compared to the substrate type.

The previous study from Cunha et al. (2018a) proposed that $\mathrm{CaP}$ bio granulation occurs through agglomeration of biomass and inorganic precipitates, and is enhanced by the addition of the divalent cation $\mathrm{Ca}^{2+}$, which contributes to the agglomeration by bridging with negatively charged biomass (microorganisms and extracellular biopolymers). The higher free energy available during anaerobic degradation of glucose $\left(\Delta \mathrm{G}_{\text {STP }}^{\mathrm{o}}\right.$ of $\left.-212 \mathrm{~kJ} \mathrm{~mol}^{-1}\right)$ compared to VFA mixture was likely the key factor behind the formation of granules in G1 and G2 (Fang and Liu, 2002; Li and Yang, 2007; Tchobanoglous et al., 2004). Note that the $\Delta \mathrm{G}_{\text {STP }}^{\mathrm{o}}$ for acetate is $-31 \mathrm{~kJ} \mathrm{~mol}^{-1}$, but for butyrate and propionate is +48 and $+76 \mathrm{~kJ} \mathrm{~mol}^{-1}$, respectively, requiring a $\mathrm{H}_{2}$ partial pressure between $10^{-4}$ and $10^{-6}$ atm for generating energy ( $\Delta \mathrm{G}^{\mathrm{o}}$ from 0 to $-25 \mathrm{~kJ} \mathrm{~mol}^{-1}$ ), which is reached under anaerobic conditions (Lier et al., 2008). The higher $\Delta \mathrm{G}^{\mathrm{o}}$ of glucose resulted in higher VSS yield (biomass and extracellular biopolymers) compared to VFA mixture as substrate (Tchobanoglous et al., 2004). Consequently, the amount of organic material available for granule formation and growth increased. The concentration of soluble and bound biopolymers for each particle size from each reactor is shown in Appendix B3. The concentration of bound biopolymers in particles $<0.4 \mathrm{~mm}$ diameter from G1 $(13.2 \pm 0.1 \mathrm{mgC}$ $\left.\mathrm{g}^{-1} \mathrm{VSS}\right)$ and $\mathrm{G} 2\left(9.1 \pm 0.1 \mathrm{mgC} \mathrm{g}^{-1} \mathrm{VSS}\right)$ was 2.4 and 1.7 , and 2.7 and 1.8 times higher than in particles from V1 (5.5 $\left.\pm 0.2 \mathrm{mgC} \mathrm{g}^{-1} \mathrm{VSS}\right)$ and V2 (4.9 $\left.\pm 0.1 \mathrm{mgC} \mathrm{g}^{-1} \mathrm{VSS}\right)$, respectively. For loose biopolymers, the result was similar. Liu et al. (2010) demonstrated that both fractions, loose and bound biopolymers, have a substantial contribution towards biomass aggregation. Moreover, Ding et al. (2015), who reviewed the role of extracellular biopolymers in bio aggregation, showed that production of biopolymers is one of the major biological forces 
ensuring stability and granule maturation. The hypothesized contribution of extracellular biopolymers to $\mathrm{CaP}$ bio granulation consists of two factors: (1) physical entrapment of $\mathrm{Ca}_{\mathrm{x}}\left(\mathrm{PO}_{4}\right)_{\mathrm{y}}$ particles and microorganisms by the extracellular biopolymers and subsequent growth of the $\mathrm{Ca}_{\mathrm{x}}\left(\mathrm{PO}_{4}\right)_{\mathrm{y}}$ core along with the internal biomass decay, and (2) internal higher supersaturation for $\mathrm{Ca}_{x}\left(\mathrm{PO}_{4}\right)_{y}$ (or higher $\mathrm{Ca}^{2+}$ ionic activity) enhanced by binding of $\mathrm{Ca}^{2+}$ with negatively charged biopolymers.

Common anaerobic granulation is stimulated by applying an upflow velocity in the UASB reactor $>100 \mathrm{~cm} \mathrm{~h}^{-1}$ (Hulshoff Pol et al., 2004; Liu et al., 2002; Liu and Tay, 2004). However, the upflow velocity applied in all reactors (G1, G2, V1, and V2) of this study was < $1 \mathrm{~cm} \mathrm{~h}^{-1}$ to simulate the conditions during anaerobic treatment of real BW (Cunha et al., 2018a). Thus, the formation of granules in this study did not depend on the upflow velocity as in common anaerobic biomass, but rather on the production of extracellular biopolymers using glucose as substrate compared to VFA mixture. The produced biopolymers stimulated the formation of the biofilm surrounding the $\mathrm{Ca}_{\mathrm{x}}\left(\mathrm{PO}_{4}\right)_{\mathrm{y}}$ core as previously observed (Cunha et al., 2018a; Tervahauta et al., 2014c). Then, syntrophic metabolism between $\mathrm{H}_{2}$ producers and consumers (acetogens and methanogens) within the biopolymer matrix induced the $\mathrm{pH}$ gradient, which favored enrichment of $\mathrm{Ca}_{\mathrm{x}}\left(\mathrm{PO}_{4}\right)_{\mathrm{y}}$ in the granules over bulk precipitation. Thus, insufficient organic material to form the outer biofilm and consequently the absence of concentrated acetoclastic and hydrogenotrophic methanogenesis to induce the $\mathrm{pH}$ gradient restricts CaP bio granulation as shown in V1. 


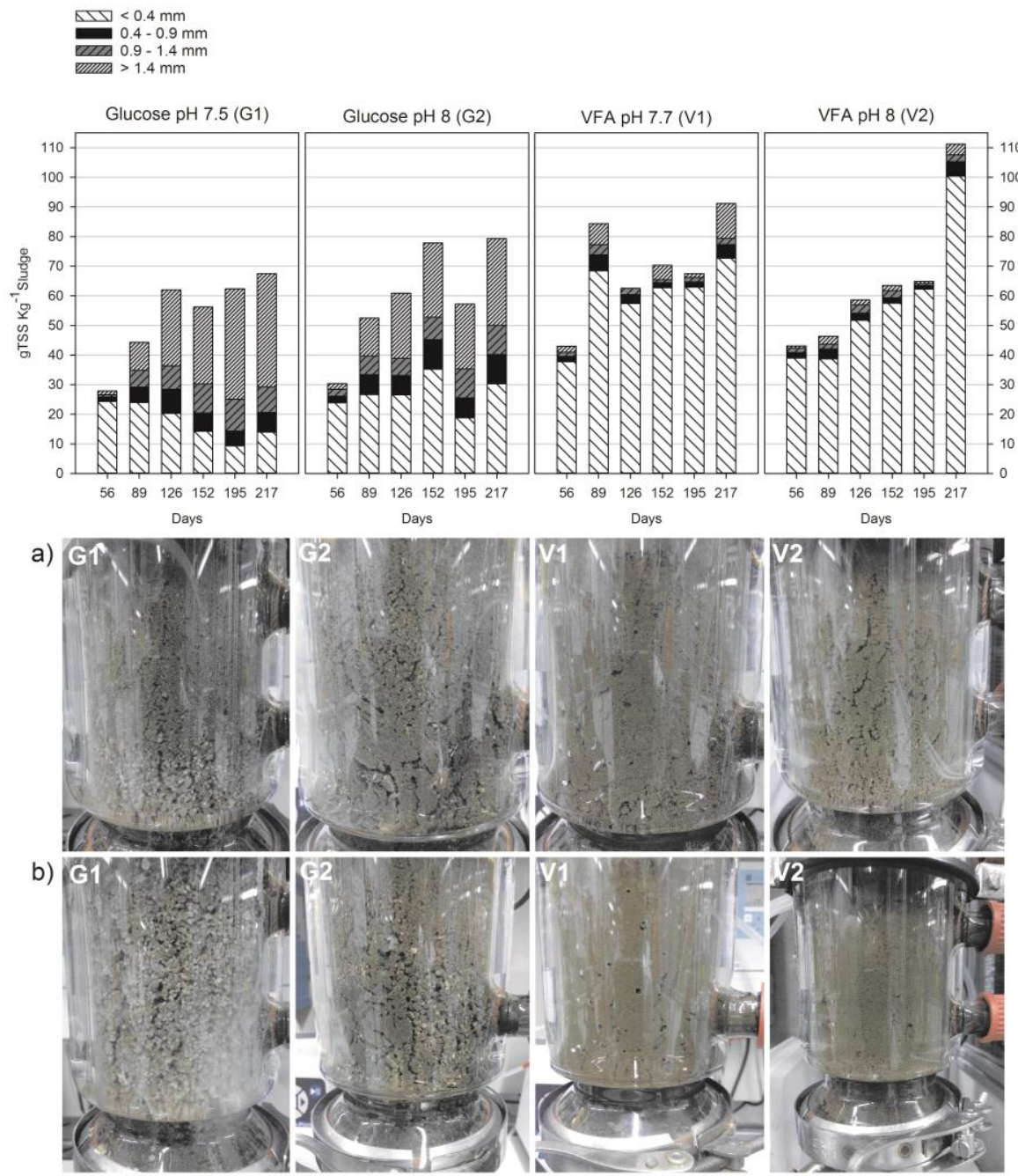

Figure 5.1 Particle size distribution $(<0.4 \mathrm{~mm}, 0.4$ to $0.9 \mathrm{~mm}, 0.9$ to $1.4 \mathrm{~mm}$, and $>1.4 \mathrm{~mm}$ diameter) of the sludge bed at $5 \mathrm{~cm}$ from the bottom of each reactor (top). Photos of the sludge bed for each reactor on operation days 102 (a) and 126 (b).

\subsubsection{Effect of bulk pH on CaP granules and location of $\mathrm{Ca}_{x}\left(\mathrm{PO}_{4}\right)_{y}$ precipitation}

$\mathrm{P}$ enrichment along with the granule growth was only observed for the reactors fed with glucose (G1 and G2), but more pronounced for G1 (bulk pH 7.5) (Figure 5.2). The $\mathrm{P}$ content in fine particles $(<0.4 \mathrm{~mm}$ diameter) was similar for both G1 and G2 (4 wt\%P), while in particles $>1.4 \mathrm{~mm}$ diameter it was significantly higher for G1 (9 wt $\%$ P) than for G2 (5 $\mathrm{wt} \% \mathrm{P}$ ). For V1 and V2, the $\mathrm{P}$ content in particles $<0.4 \mathrm{~mm}$ diameter was $6.5 \pm 1 \mathrm{wt} \%$ and even less with larger particle sizes, indicating that $\mathrm{Ca}_{\mathrm{x}}\left(\mathrm{PO}_{4}\right)_{\mathrm{y}}$ precipitation occurred mainly in the bulk as fines (Figure 5.2). For G1, the particle VSS content (or organic content) decreased 
along with granule size, from $73 \mathrm{wt} \%$ VSS for particles $<0.4 \mathrm{~mm}$ diameter to $36 \mathrm{wt} \% \mathrm{VSS}$ for particles $>1.4 \mathrm{~mm}$ diameter (Figure 5.3 left). The VSS content in fine particles $(<0.4 \mathrm{~mm}$ diameter) from G2 (49 wt\%VSS) was lower than from G1, due to the higher bulk pH, which likely enhanced bulk precipitation of $\mathrm{Ca}_{x}\left(\mathrm{PO}_{4}\right)_{y}$ and $\mathrm{CaCO}_{3}$. This is supported by the relatively high $\mathrm{Ca} / \mathrm{P}$ molar ratio in solids from $\mathrm{G} 2$, V1, and V2 (Figure 5.3 right) compared to HAP (1.67), as demonstrated above by the molar ratio of accumulated $\mathrm{Ca}^{2+}$ and $\mathrm{PO}_{4}{ }^{3-i n}$ the same reactors. For $\mathrm{G} 1$, the average $\mathrm{Ca} / \mathrm{P}$ molar ratio in solids $(1.7 \pm 0.2)$ matches with the molar ratio of accumulated $\mathrm{Ca}^{2+}$ and $\mathrm{PO}_{4}{ }^{3-}$, and it is close to the theoretical $\mathrm{Ca} / \mathrm{P}$ molar ratio of $\mathrm{HAP}$. In literature, the presence of $\mathrm{CO}_{3}{ }^{2-}$ species is reported to have a detrimental effect on $\mathrm{Ca}_{\mathrm{x}}\left(\mathrm{PO}_{4}\right)_{\mathrm{y}}$ precipitation for solution $\mathrm{pH}$ between 7.5 and 11 (Cao and Harris, 2008; Ferguson and McCarty, 1971). Moreover, bulk $\mathrm{pH}<7.5$ enables the development of the $\mathrm{pH}$ gradient between the edge and the granule center, which is crucial for preferred enrichment of $\mathrm{Ca}_{\mathrm{x}}\left(\mathrm{PO}_{4}\right)_{\mathrm{y}}$ within granules over its bulk precipitation as shown in G1. The increase of bulk pH in G2 probably disrupted the $\mathrm{pH}$ gradient, decreasing the $\mathrm{Ca}_{\mathrm{x}}\left(\mathrm{PO}_{4}\right)_{\mathrm{y}}$ enrichment in the granules.

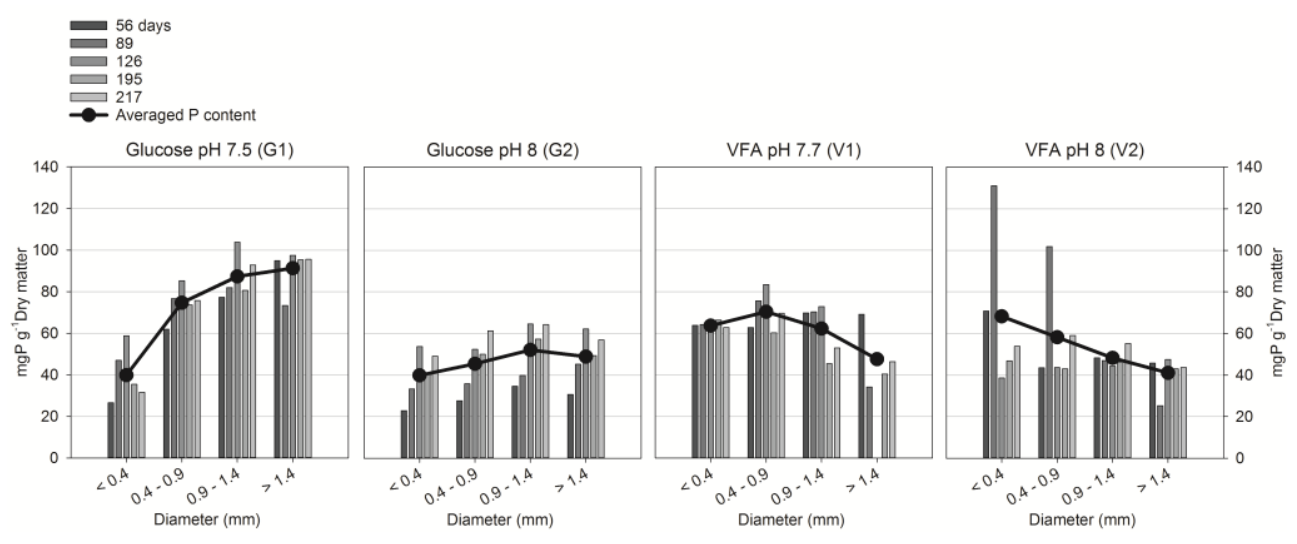

Figure 5.2 $\mathrm{P}$ content in dry matter for each particle size fraction over time and the average for each particle size fraction for each reactor. 

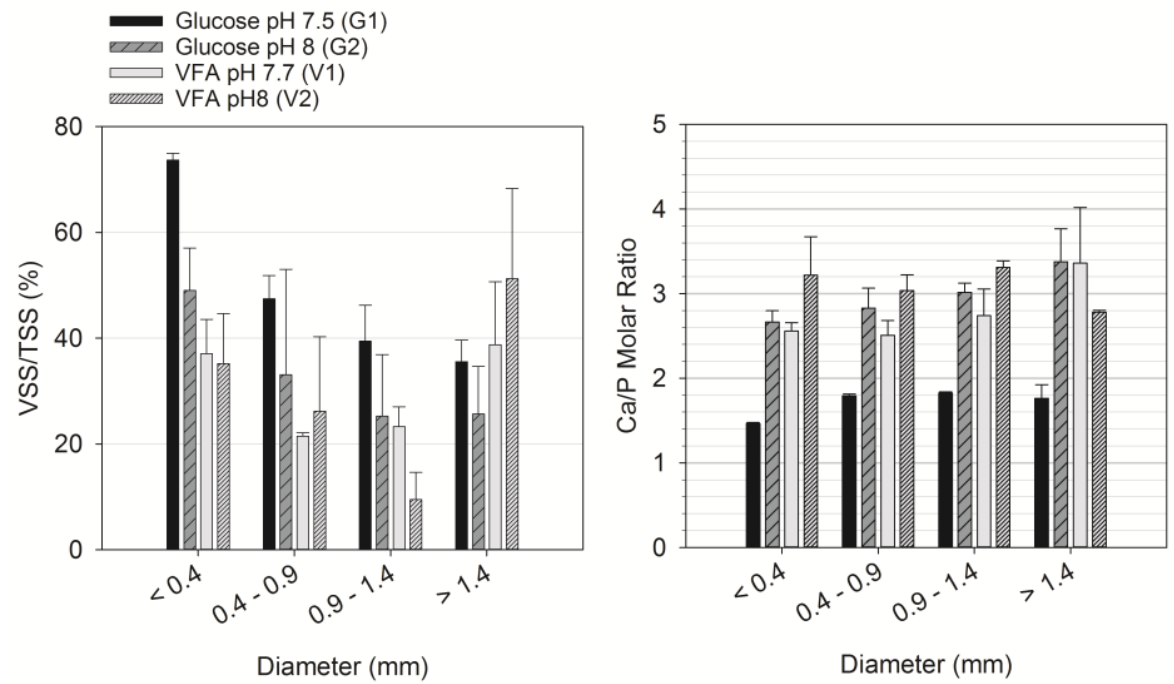

Figure 5.3 Average percentage of VSS in TSS (left) and Ca to P molar ratio in dry solids for each particle size fraction (right) for each reactor. Average were obtained from measurements on operation days 195 and 217.

\subsubsection{Comparison between CaP granules generated by glucose ( bulk pH 7.5) and BW}

In this study, CaP bio granulation was observed after 89 days while treating glucose with simulated BW chemical matrix (cations and anions), using a UASB reactor (G1) under similar operating conditions as previously described for real BW (Graaff et al., 2010). The similarity between glucose (bulk pH 7.5) and BW CaP granules was evaluated according to the elemental composition and crystallographic aspects (Figure 5.4). CaP bio granulation was observed with real BW after similar operation time (100 days) as observed in this study (Cunha et al., 2017). After 200 days of operation, the concentration of $\mathrm{CaP}$ granules (> $0.4 \mathrm{~mm}$ diameter) at $5 \mathrm{~cm}$ from the bottom of G1 (glucose $\mathrm{pH} 7.5$ ) was $51 \pm 3 \mathrm{gTSS} \mathrm{L}^{-1}$ sludge, representing $88 \%$ of the total TSS concentration in the sludge bed (Figure 5.2). For BW as influent (with $\mathrm{Ca}^{2+}$ addition), the concentration of $\mathrm{CaP}$ granules at the same reactor height was higher $\left(75 \pm 5\right.$ gTSS $\mathrm{L}^{-1}$ Sludge), but the percentage was similar (90\% of the total TSS concentration) (Cunha et al., 2018a). The presence of VSS $\left(3.4 \mathrm{~g} \mathrm{~L}^{-1}\right)$ and suspended P (176 $\mathrm{mg} \mathrm{L}^{-1}$ ) in real BW, which were not included in the glucose and nutrients solutions fed to G1, are likely the reasons for the higher concentration of $\mathrm{CaP}$ granules using $\mathrm{BW}$. The average $\mathrm{P}$ and $\mathrm{Ca}$ contents in $\mathrm{CaP}$ granules from G1 were $8.7 \pm 0.7 \mathrm{wt} \%$ and $18.2 \pm 0.5 \mathrm{wt} \%$, respectively $(\mathrm{Ca} / \mathrm{P}$ molar ratio of $1.61 \pm 0.17)$. BW CaP granules contained $6.7 \pm 1.2 \mathrm{wt} \%$ and $16.7 \pm 2.8$ wt $\%$ of $\mathrm{P}$ and $\mathrm{Ca}$, respectively $(\mathrm{Ca} / \mathrm{P}$ molar ratio of $1.93 \pm 0.67)$ (Cunha et al., 2018a). The lower $\mathrm{P}$ content in $\mathrm{BW}$ CaP granules when compared to glucose granules can perhaps be 
explained by incorporation of non-biodegradable organic and inorganic substances from BW in the $\mathrm{CaP}$ granules. This is supported by the higher VSS content $(47 \pm 3 \mathrm{wt} \%)$ and higher $\mathrm{Ca} / \mathrm{P}$ molar ratio (1.9) in $\mathrm{BW}$ granules than in glucose granules $(40 \pm 6 \mathrm{wt} \%$ and 1.6 , respectively) (Cunha et al., 2018a). Magnesium content was below $2 \mathrm{wt} \%$ for both BW and glucose granules. The Pearson correlation factor between XRD spectra of BW and glucose granules was $0.9281(n=4210)$ and $r^{2}$ Liner regression of 0.86 (Figure 5.4). Thus, because of the high similarity between BW and glucose granules and the applied conditions in the respective reactors, the required conditions for $\mathrm{CaP}$ bio granulation tested in this study can be extrapolated for anaerobic treatment of BW.

Cunha et al. (2018b) proposed that internal hydrogenotrophic methanogenesis in the outer biofilm of $\mathrm{CaP}$ granules from $\mathrm{BW}$ promotes a $\mathrm{pH}$ gradient from 7.5 at the edge to 8 in the granule core, which is essential for preferable $\mathrm{Ca}_{\mathrm{x}}\left(\mathrm{PO}_{4}\right)_{\mathrm{y}}$ formation in the granules over bulk precipitation. In this study we confirmed that $\mathrm{CaP}$ bio granulation is biologically induced. The biological role is based on the production of extracellular biopolymers which are used for biofilm formation, trapping microorganisms and $\mathrm{Ca}_{x}\left(\mathrm{PO}_{4}\right)_{y}$ particles. The produced biopolymers and $\mathrm{Ca}^{2+}$ complexation act as gluing agents, strengthening the organic-inorganic matrix (More et al., 2014). Then, local microbial syntrophy ( $\mathrm{H}_{2}$ producers and consumers) promote the development of the increasing $\mathrm{pH}$ gradient between the bulk and the granule center as previously reported in Cunha et al. (2018b), which is essential for $\mathrm{Ca}_{\mathrm{x}}\left(\mathrm{PO}_{4}\right)_{\mathrm{y}}$ enrichment in the granules. The COD used for biomass growth in G1 represented $11 \%(0.08$ $\left.\operatorname{gVSS~} \mathrm{g}^{-1} \mathrm{COD}_{\text {Influent }}\right)$ of the total incoming COD, while in V1 only $4 \%$ (0.03 gVSS $\mathrm{g}$ $\left.{ }^{1} \mathrm{COD}_{\text {Influent }}\right)$. Inhibition by $\mathrm{pH}$ was not observed for $\mathrm{G} 1$ neither for $\mathrm{V} 1$. Also at $25^{\circ} \mathrm{C}$, the biomass yield for anaerobic treatment of BW $\left(0.09 \mathrm{gVSS} \mathrm{g}^{-1} \mathrm{COD}_{\text {Influent }}\right)$ was closer to $\mathrm{G} 1$ than to V1. The higher biomass yield obtained by acidogenesis (fermentation) when compared to only acetogenesis and methanogenesis might be a stimulator for $\mathrm{CaP}$ bio granulation. Thus, for the implementation of $\mathrm{CaP}$ bio granulation process in other wastewater types particular attention should be given to the carbon source composition besides the chemical matrix (cations and anions) and the thermodynamic conditions (bulk pH) for $\mathrm{Ca}_{\mathrm{x}}\left(\mathrm{PO}_{4}\right)_{\mathrm{y}}$ precipitation. 

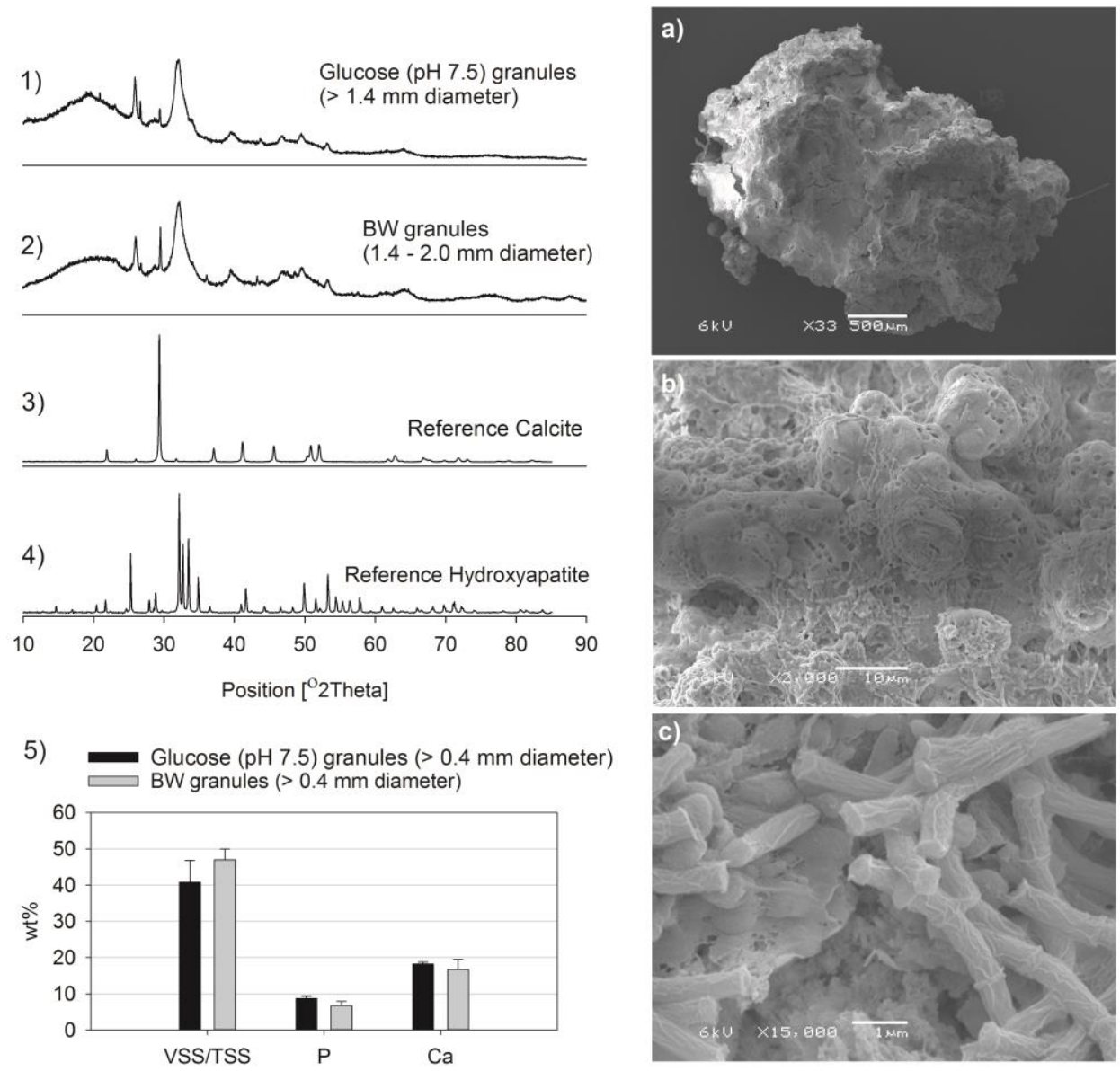

Figure 5.4 XRD patterns of glucose granules (> $1.4 \mathrm{~mm}$ diameter) from G1 (1) and BW granules (2), and reference patterns of calcite and hydroxyapatite (3 and 4, respectively). Elemental composition of glucose $(\mathrm{pH}$ 7.5) and $\mathrm{BW}$ granules (5). Scanning electron microscope (SEM) images of a representative glucose granule from G1 (a) and magnified images of the granule surface (a) and the microbial morphology (c). 


\section{Chapter 6. Recovery of calcium phosphate granules from black water using a hybrid Upflow Anaerobic Sludge Blanket - Gas-Lift (UASB-GL) reactor}

C. Schott and J. R. Cunha, R. D. van der Weijden, L. Hernández Leal, G. Zeeman, C. J. N. Buisman

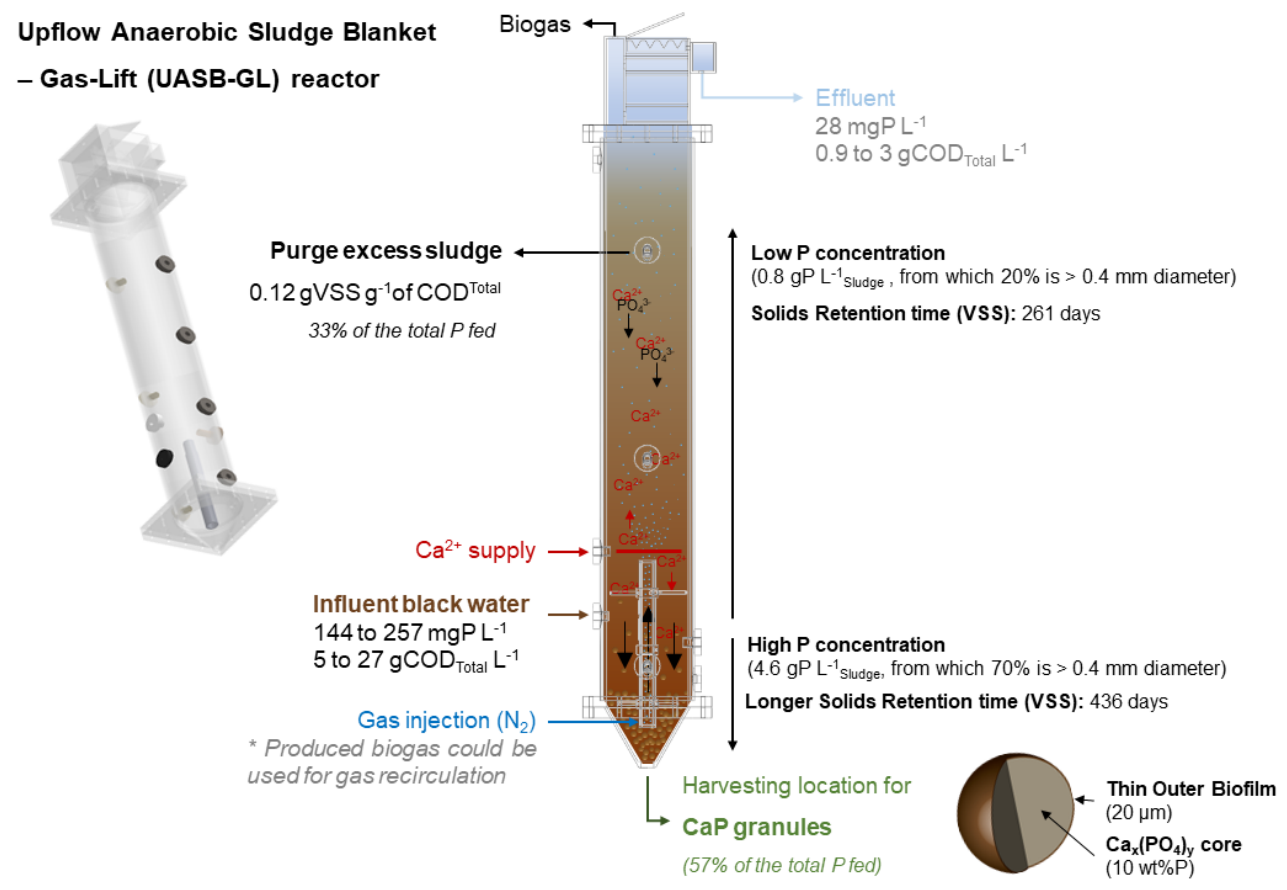

This chapter was submitted as:

J. R. Cunha, C. Schott, R. D. van der Weijden, L. Hernández Leal, G. Zeeman, C. J. N. Buisman, 2018. Recovery of calcium phosphate granules from black water using a hybrid Upflow Anaerobic Sludge Blanket - Gas-Lift (UASBGL) reactor. 


\begin{abstract}
Addition of calcium during anaerobic digestion of vacuum collected black water (BW) in an upflow anaerobic sludge blanket (UASB) reactor increased the retention of total phosphorus $(\mathrm{P})$ in the reactor from $51 \%$ to $87 \%$. However, the insufficient mixing in the UASB reactor caused cementation and relatively high content of organics in the recovered calcium phosphate $(\mathrm{CaP})$ granules, limiting the P recovery. In this study, we combine a UASB with an internal gas-lift mixing (UASB-GL) to prevent cementation and to enhance the $\mathrm{P}$ content in CaP granules. The novel UASB-GL reactor had a volume of $45 \mathrm{~L}$ and operated for 300 days treating BW. At steady state, weekly monitoring of influent and effluent showed removal of $92 \%$ and $90 \%$ of total COD and $\mathrm{P}$, respectively. At steady state, the gas injection created a sludge bed with a total suspended solids concentration of $73 \pm 15 \mathrm{~g} \mathrm{~L}^{-1}$ at the bottom and $31 \pm$ $5 \mathrm{~g} \mathrm{~L}^{-1}$ at the top of the reactor. The $\mathrm{P}$ solids were concentrated at the bottom of the reactor with $4.58 \pm 1.34 \mathrm{gP} \mathrm{L}^{-1}$, while at the top a much lower concentration was obtained $(0.75 \pm 0.32$ $\left.\mathrm{gP} \mathrm{L}^{-1}\right)$. This allows harvesting $\mathrm{P}$ at the bottom of the reactor. The $\mathrm{CaP}$ granules $(>0.4 \mathrm{~mm}$ diameter) in the UASB-GL reactor contained in average $7.8 \mathrm{wt} \% \mathrm{P}$, and $89 \%$ of the sampled $\mathrm{CaP}$ granules were harvested from the bottom.
\end{abstract}




\subsection{Introduction}

Sustainability in wastewater treatment is closely related to the recovery of valuable and diminishing natural resources (Abu-Ghunmi et al., 2016; Mo and Zhang, 2013). The natural source of phosphorus $(\mathrm{P})$, phosphate rock, is dwindling and geopolitically imbalanced. Moreover, the costs for $\mathrm{P}$ extraction from phosphate rock are increasing, due to the rising contamination with heavy metals and radioactive by-products (Cordell et al., 2009; Koppelaar and Weikard, 2013). Additionally, P runoff from agriculture and P discharge from wastewater treatment plants to surface water is causing a loss of biodiversity in aquatic environments due to eutrophication (Jarvie et al., 2006). Therefore, the recovery of P from waste streams is essential for protecting the environment and for providing future generations with $\mathrm{P}$, which is a vital nutrient for food production (Elser, 2012; Mehta et al., 2015; Yuan et al., 2012).

In Sneek (the Netherlands), 32 households are equipped with vacuum toilets, using 1 $\mathrm{L}$ of water per flush. Due to the separation from gray water and vacuum collection, black water (BW) is highly concentrated in organic matter and nutrients, containing on average $10 \mathrm{~g} \mathrm{~L}^{-1}$ of COD and $0.2 \mathrm{~g} \mathrm{~L}^{-1}$ of $\mathrm{P}$ (Graaff et al., 2010). Therefore, BW is an interesting stream for resource recovery. Simultaneous recovery of calcium phosphate granules (CaP granules) and methane could be achieved using an upflow anaerobic sludge blanket (UASB reactor) for BW treatment (Tervahauta et al., 2014c). Most likely, the formation of CaP granules occurs by agglomeration of precipitated calcium phosphate species $\left(\mathrm{Ca}_{\mathrm{x}}\left(\mathrm{PO}_{4}\right)_{\mathrm{y}}\right)$ and organic material, containing microorganisms and extracellular polymeric substances (EPS) (Cunha et al., $2018 b)$. In time, the agglomerates grow in size along with the maturation of the $\mathrm{Ca}_{\mathrm{x}}\left(\mathrm{PO}_{4}\right)_{\mathrm{y}}$ rich core, forming $\mathrm{CaP}$ granules. The addition of calcium $\left(\mathrm{Ca}^{2+}\right)$ increases both the retention of $\mathrm{P}$ in the UASB reactor from $51 \%$ to $89 \%$ and the CaP bio granulation rate (Cunha et al., 2018a). The formation of $\mathrm{CaP}$ granules in the sludge bed does not hinder the anaerobic digestion, but from the $89 \%$ accumulated P, only $31 \%$ was so far recovered as CaP granules (Cunha et al., 2018a, 2017).

The high concentration of solids in BW results in application of relatively long hydraulic retention time (HRT), and therefore, low upflow velocity, resulting in low mixing (Graaff et al., 2010). Dosing $\mathrm{Ca}^{2+}$, which is a divalent cation, further limits the mixing due to the increased concentration of solids in the sludge bed by bridging of $\mathrm{Ca}^{2+}$ with negatively charged compounds (EPS and microbial cell surfaces) and precipitation of $\mathrm{Ca}_{\mathrm{x}}\left(\mathrm{PO}_{4}\right)_{\mathrm{y}}$ and calcium carbonate $\left(\mathrm{CaCO}_{3}\right)$ (Dang et al., 2014; Langerak et al., 1998). The limited mixing in the UASB reactor used by Cunha et al. (2018a) led to the accumulation of $\mathrm{Ca}^{2+}$ at the bottom 
of the reactor, triggering cementation at the bottom by precipitation of bare $\mathrm{Ca}_{\mathrm{x}}\left(\mathrm{PO}_{4}\right)_{\mathrm{y}}$ and $\mathrm{CaCO}_{3}$, which was not recoverable. Additionally, the low movement inside the sludge bed, due to the low upflow velocity, reduced the settling of denser particles. Therefore, mature $\mathrm{CaP}$ granules were undesirably spread in the sludge bed.

In this study, we propose a novel bioreactor design to stimulate the formation of $\mathrm{CaP}$ granules and increase the concentration of mature granules at the harvesting location. The conventional UASB reactor is modified by the addition of a concentric draft tube (riser) with gas injection at the bottom part, which is typical for gas-lift (GL) reactors. The gas is injected at the lower end of the draft tube, decreasing the density of the gas-liquid mixture in the riser and thereby lifting it. Accordingly, the density outside the riser is kept higher than inside and the liquid flows downward, creating a loop which lifts particles from the bottom of the reactor, enabling gentle mixing at the upper part (Lestinsky et al. 2012).

The novel UASB-GL reactor was operated and monitored in this study. Sludge bed analysis was conducted over time to describe the effect of the mixing induced by the internal loop at the bottom of the reactor on the particle size and $\mathrm{P}$ distributions. $\mathrm{CaP}$ granules harvested from the bottom of the UASB-GL reactor were characterized and compared with CaP granules formed in previous studies (Cunha et al., 2018a; Tervahauta et al., 2014c). Finally, the internal loop in the UASB-GL reactor was modeled to evaluate the fluid motion.

\subsection{Materials and Methods}

\subsubsection{Experimental setup}

The UASB-GL reactor has an effective working volume of 45 L. Figure 6.1 illustrates the experimental setup. The reactor was continuously heated at $25^{\circ} \mathrm{C}$ with a water bath (Thermo Fischer 003-2859) connected to the doubled wall. The inoculum (20 L) was taken from a UASB reactor treating BW (Tervahauta et al., 2014c). BW was vacuum collected in Sneek (the Netherlands) and stored at $7^{\circ} \mathrm{C}$ in a stirred storage tank of $200 \mathrm{~L}$. Influent BW and $\mathrm{CaCl}_{2} \cdot 2 \mathrm{H}_{2} \mathrm{O}$ solution were pumped into the reactor by Masterflex (7523-70) pumps using the valves in the scheme. $\mathrm{CaCl}_{2} \cdot 2 \mathrm{H}_{2} \mathrm{O}$ was added at $250-300 \mathrm{mgCa} \mathrm{LBW}^{-1}$ (adapted from Cunha et al. (2018a)), representing $8 \%$ of the volumetric loading rate (VLR, $\mathrm{L} \mathrm{d}^{-1}$ ) of BW. Nitrogen $\left(\mathrm{N}_{2}\right)$ gas was injected in between the two cylinders of the riser, escaping from the outlet at the bottom (Figure 6.1b). The electrically steered gas valve controlled the injection of $\mathrm{N}_{2}$ from a 2 bar pressured gas line. All inlets $\left(\mathrm{BW}, \mathrm{CaCl}_{2} \cdot 2 \mathrm{H}_{2} \mathrm{O}\right.$, and $\mathrm{N}_{2}$ ) were steered via an external master timer. $\mathrm{BW}$ and $\mathrm{CaCl}_{2} \cdot 2 \mathrm{H}_{2} \mathrm{O}$ solution were pumped for 1 minute every 119 minutes with flows of $250 \mathrm{ml} \mathrm{min}^{-1}$ and $20 \mathrm{ml} \mathrm{min}^{-1}$, respectively. $\mathrm{N}_{2}$ gas was injected 1 minute 
every 29 minutes with an approximate flow of $300 \mathrm{ml} \mathrm{min}^{-1}$, which was monitored with a gas flow meter. The $\mathrm{pH}$, temperature, and redox were measured by three vertically distributed sensors (Memosens CPS16D-1014/0 Orbisint) and were logged in a data logger from Endress+Hauser (F1035805G00). The total volume of produced biogas and $\mathrm{N}_{2}$ was measured daily using a Ritter TG/05/5. The reactor is equipped with five vertically distributed valves shown as sampling points in Figure 6.1.

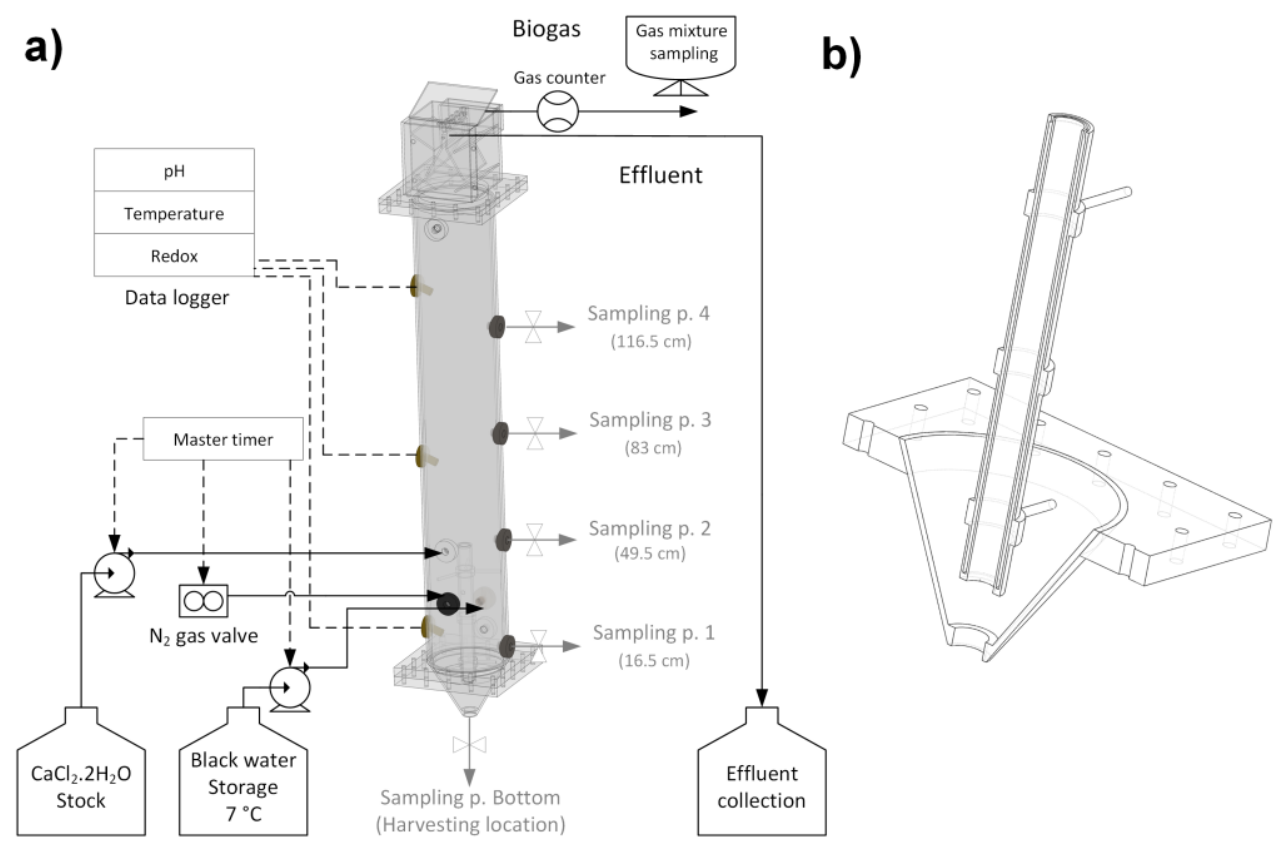

Figure 6.1 Technical illustration of the UASB-GL reactor setup (a), and detailed representation of the riser and bottom of the reactor (b).

\subsubsection{Sampling and analysis program}

Daily, the $\mathrm{CaCl}_{2} \cdot 2 \mathrm{H}_{2} \mathrm{O}$ solution and effluent containers were weighed. Furthermore, the amount of gas leaving the GLS, the flow of $\mathrm{N}_{2}$ gas entering the reactor, and the three measuring points of $\mathrm{pH}$, redox potential, and temperature were also noted daily. Influent, effluent, and gas compositions were measured once a week. The overflow effluent was continuously collected in a jerrycan, but for weekly analysis, a new collection was performed for $24 \mathrm{~h}$. BW was sampled from a T-connection immediately before entering the reactor. The measurements and methods were adapted from Cunha et al. (2018a) and included: total and volatile suspended solids (TSS and VSS, respectively); total, colloidal, and soluble COD (COD $_{\text {Total }}, \mathrm{COD}_{\text {Colloidal, }}$ and $\mathrm{COD}_{\text {Soluble, }}$ respectively); total, organic, and inorganic carbon (TC, TOC and IC, respectively); volatile fatty acids (VFA); ammonium $\left(\mathrm{NH}_{4}^{+}\right)$; anions $\left(\mathrm{Cl}^{-}, \mathrm{NO}_{3}{ }^{-}\right.$, 
$\mathrm{NO}_{2}{ }^{-}, \mathrm{SO}_{4}{ }^{2-}$, and $\mathrm{PO}_{4}{ }^{3-}$ ); and total and soluble elements ( $\mathrm{P}, \mathrm{Ca}, \mathrm{Mg}, \mathrm{K}$, and $\mathrm{Na}$ ). The gas passing the GLS was weekly collected in a gas bag after the flow meter over approximately four hours to obtain a representative mixture of biogas and $\mathrm{N}_{2}$ gas. The gas mixture was analyzed as described by Cunha et al. (2018a). Sampling of the sludge bed was performed on operation days $167,204,258$, and 300. Sludge was taken from sampling points 4 to 1 and bottom in the same order. From point 4 to 1 about $200 \mathrm{ml}$ of sludge were taken, while at the bottom the amount was increased to $500 \mathrm{ml}$. For sampling, the valves were shortly and widely opened. The sampled sludge was separated with mesh sieves in size fractions of $<0.4 \mathrm{~mm}, 0.4$ to 0.9 $\mathrm{mm}, 0.9$ to $1.4 \mathrm{~mm}, 1.4$ to $2 \mathrm{~mm}, 2$ to $2.5 \mathrm{~mm}$, and > $2.5 \mathrm{~mm}$. After the particle size separation, the solids were analyzed for total elements, TSS, and VSS as described in Cunha et al. (2018a). Only particles $>0.4 \mathrm{~mm}$ diameter were considered as $\mathrm{CaP}$ granules.

\subsubsection{Calculations}

The hydraulic retention time (HRT) was calculated based on the weight of the collected effluent, the $\mathrm{CaCl}_{2} \cdot 2 \mathrm{H}_{2} \mathrm{O}$ solution, and the effective reactor volume. The difference between the produced effluent and the consumed $\mathrm{CaCl}_{2} \cdot 2 \mathrm{H}_{2} \mathrm{O}$ solution for a defined time was assumed as the volume of BW fed. The amount of biogas was calculated by taking the cumulative amount of $\mathrm{N}_{2}$ entering the reactor and subtracting it from the total amount of gas leaving the GLS based on daily averages. The COD of suspended solids ( $\left.\mathrm{COD}_{\mathrm{SS}}\right), \mathrm{COD}_{\mathrm{Colloida}}$, and organic loading rate (OLR) were calculated as described by Graaff et al. (2010) and Halalsheh et al. (2005). The concentration of $\mathrm{HCO}_{3}{ }^{-}$is a function of measured inorganic carbon, temperature, and $\mathrm{pH}$ (Cunha et al., 2018a). The concentration of TSS, VSS, and particulate $\mathrm{P}$ in the reactor (Solids, $\mathrm{g} \mathrm{L}^{-1}$ reactor) was calculated according to eq. 6.1 for each sampling day $(167,204,258$, and 300). The solids retention time (SRT, days) was calculated

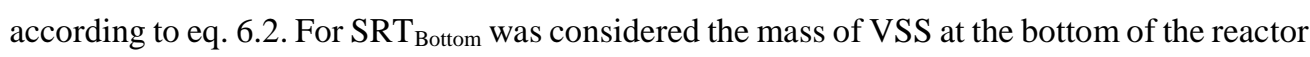
$(12 \mathrm{~L})$ and the VSS sampled from taps 0 and 1 . For $\mathrm{SRT}_{\text {Top }}$ was considered the mass of VSS at the top of the reactor ( $34 \mathrm{~L}$ ), the VSS sampled and wasted from taps 2,3 , and 4, and the VSS washout in the effluent. The retention times for total $\mathrm{P}$ and $\mathrm{P}$ as $\mathrm{CaP}$ granules were calculated also with eq. 6.2, but using the mass of total $\mathrm{P}$ and $\mathrm{P}$ as $\mathrm{CaP}$ granules instead of VSS. The sludge ( $\left.\mathrm{gVSS} \mathrm{d}^{-1}\right)$ and solid P production $\left(\mathrm{gP} \mathrm{d}^{-1}\right)$ were calculated according to eq. 6.3 and 6.4, respectively. The solid $\mathrm{P}$ production was further divided into $\mathrm{CaP}$ granules $(>0.4$ $\mathrm{mm}$ diameter) and fine particles $(<0.4 \mathrm{~mm}$ diameter $)$. 
Solids $=\frac{\sum_{i=0}^{4}\left(x_{i} V_{i}\right)}{V_{\text {reactor }}}$

Equation 6.1

where $V_{i}\left(\mathrm{~L}_{\text {Sludge }}\right)$ is the sludge volume of each sampled height $(3.46,8.27,8.49$, and $8.47 \mathrm{~L}$ for sampling point $0,1,2$, and 3 , respectively, and for the sampling point $4, V_{4}$ was adapted according to the sludge bed height), $x_{i}$ ( $\mathrm{g} \mathrm{L}^{-1}$ Sludge $)$ is the concentration of TSS, VSS, or particulate $\mathrm{P}$, and $V_{\text {reactor }}$ is the total effective reactor volume $(45.38 \mathrm{~L})$. Note that all volumes were gravimetrically measured before the start of the reactor operation.

$S R T=\frac{[V S S]_{\text {reactor }}}{[V S S]_{\text {Wash out }}+[\text { VSS }]_{\text {wasted and sampled }}}$

Equation 6.2

where $[V S S]_{\text {reactor }}(\mathrm{g})$ is the overall concentration of VSS in the reactor, $[V S S]_{\text {Wash out }}\left(\mathrm{g} \mathrm{d}^{-}\right.$ $\left.{ }^{1}\right)$ is the VSS loading in washout with the effluent, and $[V S S]_{\text {wasted and sampled }}\left(\mathrm{g} \mathrm{d}^{-1}\right)$ is the amount of sampled VSS and VSS in purged excess sludge divided by the operation time.

Sludge production $=\frac{\text { VSS } S_{\text {wasted and sampled }}+\text { VSS } S_{\text {washout }}}{t}$

Equation 6.3

where $V S S_{\text {wasted and sampled }}(\mathrm{g})$ is the mass of VSS wasted and sampled, VSS washout $(\mathrm{g})$ is the mass of VSS in the effluent, and $t$ (days) is the associated operation time.

Total $P$ production $=\frac{P_{\text {wasted } \text { and } \text { sampled }}}{t}$

Equation 6.4

where $P_{\text {wasted and sampled }}(\mathrm{g})$ is the mass of total $\mathrm{P}$ sampled and waste. For P production as $\mathrm{CaP}$ granules $P_{\text {wasted and sampled }}$ corresponded to the mass of $\mathrm{P}$ sampled as particles $>0.4 \mathrm{~mm}$ diameter.

\subsubsection{Multiphysics modulation (COMSOL)}

The reactor was true to scale build in COMSOL in a two-dimensional axis symmetric study. The software physics "turbulent bubbly flow" solves for liquid velocity, gas volume fraction, pressure, and viscosity of a gas-liquid mixture and was used to model the gas-lift induced loop flow. It is based on the two-fluid Euler-Euler model. This macroscopic model treats the gas and liquid phase as interpenetrating media and is tracking the averaged concentration of each phase. Based on a momentum balance and a continuity equation the individual velocity fields of each phase interact with each other (Appendix C1). The assumptions made in this model are that the gas density is negligible compared to the density of the liquid, both phases share one pressure field, and the balance between viscous drag and 
pressure forces determines the motion of the gas bubbles relative to the liquid (COMSOL, 2014; Sokolichin et al., 2004).

The experimental conditions during the operation were used as input for the model. The model simulated the flow regimes during gas injection. The gas inflow was $300 \mathrm{ml} \mathrm{min}{ }^{-1}$ and the time of injection was $1 \mathrm{~min}$, which was shortened if a stationary flow field developed earlier to minimize computation time. The different flow behavior of the sludge bed compared to water was approached by increasing the dynamic viscosity of the liquid phase to $1 \mathrm{~Pa} s$, based on rheology measurements and studies investigating dynamic viscosities of sludge mixtures (Dai et al., 2014; Pevere et al., 2006). The model was tested on different mesh sizes and is mesh independent. The mesh layout used is shown in Appendix C1.

\subsection{Results}

\subsubsection{Treatment performance}

The operational period was split into three phases (Table 6.1 and Figure 6.2). Phase 1, from 0 to 84 days, was considered the start-up period. In phase 2, from day 84 to 189 , the BW was significantly less concentrated at the collection point in Sneek (the Netherlands). Phase 3 lasted from day 189 to 300 and was a period with highly concentrated BW, due to the accumulation of solids in the vacuum collection tank at the community site in Sneek. The feeding of BW was lowered during phase 3 to keep an OLR close to 1 gCOD L-1 $\mathrm{d}^{-1}$.

The key performance parameters are presented in Table 6.1. The removal of $\mathrm{COD}_{\text {Total }}$ was consistently above $80 \%$ during phase 1 and 3 except for operations days 210, 280, and 287, where sludge was washed out due to high solids input from BW (10 to 20 gTSS L$^{-1}$ as shown in Figure 6.2). The removal of $\mathrm{COD}_{\text {Total }}$ dropped during phase 2, due to the higher ratio of dissolved inert COD/COD ${ }_{\text {Total }}$ in the influent BW (Figure 6.2). The concentration of $\mathrm{COD}_{\text {Total }}$ in the effluent was similar for phase 1 and 2 . The cumulative COD mass balance is presented in Figure 6.3, including the sludge washout and wasted (sampled and excess sludge). From the total $9.3 \mathrm{kgCOD}_{\text {Total }}$ fed, $36 \%$ was measured as $\mathrm{CH}_{4}, 14 \%$ left the reactor with the effluent, $18 \%$ was accumulated in the reactor, and $8 \%$ was wasted and sampled. The unquantified fraction of $\mathrm{COD}_{\text {Total }}$ represented 24\%. The missing COD fraction in the mass balance can be explained by two factors: (1) inaccurate sludge bed sampling, underestimating the COD accumulated in the reactor, and (2) undetected variations in $\mathrm{N}_{2}$ flow $\left(13 \pm 4 \mathrm{~L} \mathrm{~d}^{-1}\right)$, resulting in inaccurate $\mathrm{CH}_{4}$ quantification. Undetected COD in the effluent is improbable because effluent was weekly measured and during the periods with washout a higher 
monitoring frequency was performed to estimate the COD washout accurately. The measured ratio $\mathrm{gCOD} \mathrm{gVSS}^{-1}$ was 2 .

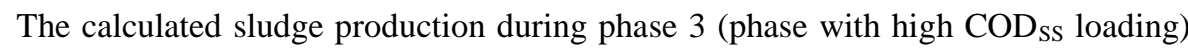
was $4.29 \mathrm{gVSS} \mathrm{d}^{-1}$, representing $0.126 \mathrm{gVSS}_{\mathrm{gCOD}} \mathrm{Bw}^{-1}$. The loading rate during phase 2 was only $0.3 \mathrm{gCOD} \mathrm{L} \mathrm{g}^{-1} \mathrm{~d}^{-1}$. Consequently, the SRT in phase 2 became extremely long (719 days) and decreased to 290 days in phase 3. The TSS and VSS concentrations in the sludge bed over time are presented in Figure $6.3 \mathrm{c}$ and $\mathbf{d}$, respectively. During phase 3, the sludge bed contained $73 \pm 16 \mathrm{gTSS} \mathrm{L}^{-1}$ and $40 \pm 7 \mathrm{gVSS} \mathrm{L}^{-1}$ at the bottom (harvesting location) and $31 \pm$ $5 \mathrm{gTSS} \mathrm{L}^{-1}$ and $23 \pm 4 \mathrm{gVSS} \mathrm{L}^{-1}$ at the top of the reactor (tap 4). Although sludge was sampled from all taps, the SRT for the top part of the reactor was higher than for the bottom part, because of VSS washout from the top with the effluent and higher volume of VSS sampled (tap 2 to 4$)$.

The average $\mathrm{pH}$ in the UASB-GL reactor went from $6.87 \pm 0.04$ on operation day 10 up to $7.75 \pm 0.06$ on operation day 181. Accordingly, the concentration of $\mathrm{HCO}_{3}{ }^{-}$changed from $0.92 \pm 0.003$ up to $3.95 \pm 0.01 \mathrm{gHCO}_{3}{ }^{-} \mathrm{L}^{-1}$ (Figure 6.2). The concentration of VFA in the effluent was $<1 \mathrm{mg} \mathrm{L}^{-1}$ during the entire operation, and the average of $\mathrm{NH}_{4}{ }^{+}-\mathrm{N}$ concentration in the effluent was $0.79 \pm 0.19 \mathrm{~g} \mathrm{~L}^{-1}$ (results not shown).

The average $\mathrm{P}_{\text {Total }}$ removal in phase 3 was $90 \%$ when the days with washout are excluded. Most of the $\mathrm{P}_{\text {Total }}$ entered the reactor in the solid form $(\sim 75 \%)$. The removal efficiency of soluble $\mathrm{P}\left(\mathrm{PO}_{4}{ }^{3-}\right)$ was the highest in phase $3(88 \%)$ and the lowest during startup in phase 1 (73\%) as shown in Table 6.1. According to the P mass balance (Figure 6.3) during the 300 days of operation, $127 \mathrm{~g}$ of $\mathrm{P}_{\text {Total }}$ were fed to the UASB-GL reactor. Then, from the $\mathrm{P}_{\text {Total }}$ fed, $15 \%$ was measured in the effluent and $56 \%$ was measured in the sludge bed, sampled, and wasted resulting in $29 \%$ of $\mathrm{P}$ that remained unquantified but most likely due to inaccurate quantification of $\mathrm{P}$ in the sludge bed, since the effluent composition was thoroughly measured. The $\mathrm{P}$ measured as $\mathrm{CaP}$ granules (> $0.4 \mathrm{~mm}$ diameter) represented $29 \%$ of the total $\mathrm{P}$ fed (Figure 6.3). Throughout all phases, the accumulation of $\mathrm{Ca}_{\text {Total }}$ from $\mathrm{BW}$ plus added $\mathrm{Ca}^{2+}$ was $80 \pm 11 \%$. 
Table 6.1 Key operational and performance parameters of the UASB-GL reactor for the three operation phases. Average values for removal efficiencies during phase 3 do not include operation days 210,280 , and 287 , because excess of sludge was not taken on time to avoid washout of solids, which resulted from the high solids inflow (Appendix C2)

\begin{tabular}{|c|c|c|c|c|c|c|c|}
\hline Parameter & Unit & Phase 1 & sd & Phase 2 & sd & Phase 3 & sd \\
\hline Operation days & & $0-84$ & & $84-189$ & & $189-300$ & \\
\hline HRT & Days & 17.22 & 1.95 & 18.51 & 1.41 & 31.57 & 15.13 \\
\hline OLR & $\operatorname{gCOD~L} \mathrm{L}^{-1} \mathrm{~d}^{-1}$ & 0.82 & 0.02 & 0.30 & 0.14 & 0.96 & 0.30 \\
\hline Influent $\mathrm{COD}_{\text {Total }}$ & $\mathrm{gCOD} \mathrm{L}^{-1}$ & 14.39 & 3.90 & 5.25 & 2.19 & 26.66 & 8.65 \\
\hline Influent $\mathrm{COD}_{\mathrm{sS}}$ & $\mathrm{gCOD} \mathrm{L}^{-1}$ & 8.67 & 3.66 & 2.77 & 1.94 & 20.80 & 7.51 \\
\hline Effluent $\mathrm{COD}_{\text {Total }}$ & $\mathrm{gCOD} \mathrm{L}^{-1}$ & 0.9 & 0.3 & 0.9 & 0.1 & 2.9 & 2.4 \\
\hline $\mathrm{COD}_{\text {Total }}$ Removal & $\%$ & 93.05 & 2.59 & 78.07 & 7.15 & 92.21 & 4.24 \\
\hline $\mathrm{COD}_{\text {Soluble }}$ Removal & $\%$ & 83.79 & 5.32 & 67.08 & 8.70 & 79.87 & 5.45 \\
\hline Influent $\mathrm{P}_{\text {Total }}$ & $\mathrm{mgP} \mathrm{L}^{-1}$ & 203.44 & 54.23 & 144.06 & 56.51 & 257.69 & 54.88 \\
\hline Influent $\mathrm{PO}_{4}{ }^{3-}$ & $\mathrm{mgPO}_{4}{ }^{3-}-\mathrm{PL}^{-1}$ & 49.80 & 14.03 & 32.73 & 8.34 & 68.26 & 22.08 \\
\hline Effluent $P_{\text {Total }}$ & $\mathrm{mgP} \mathrm{L}^{-1}$ & 25.12 & 15.98 & 14.64 & 1.00 & 42.89 & 50.50 \\
\hline $\mathrm{P}_{\text {Total }}$ Removal & $\%$ & 87.08 & 9.97 & 89.69 & 4.39 & 90.43 & 3.61 \\
\hline $\mathrm{PO}_{4}{ }^{3-}$ Removal & $\%$ & 72.51 & 22.65 & 76.98 & 7.08 & 88.22 & 6.40 \\
\hline SRT & Days & Startup & & 719 & & 290 & \\
\hline $\mathrm{SRT}_{\text {Bottom }}$ & Days & & & & & 436 & \\
\hline $\mathrm{SRT}_{\text {Top }}$ & Days & & & & & 261 & \\
\hline
\end{tabular}

a)

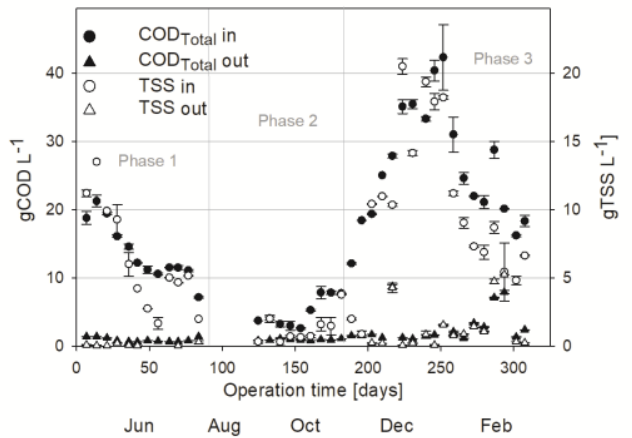

b)

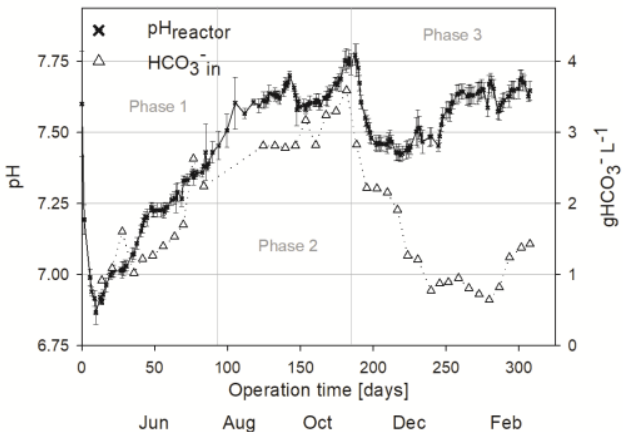

Figure 6.2 Influent and effluent concentrations of total COD and TSS during the entire operational period (300 days) (a). Average $\mathrm{pH}$ of the sludge bed and bicarbonate $\left(\mathrm{HCO}_{3}^{-}\right)$ concentration in the influent BW (b). 

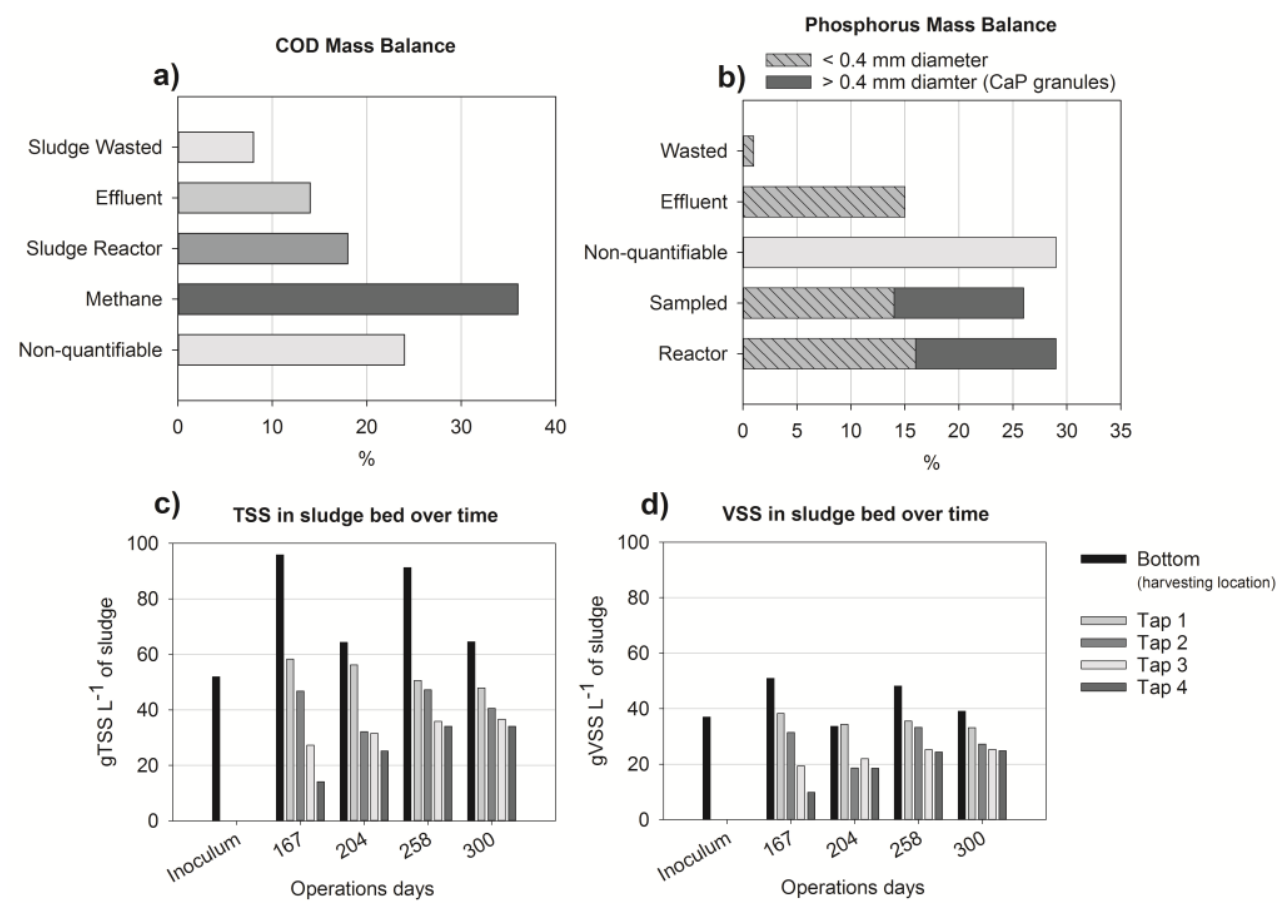

Figure 6.3 COD (a) and P (b) mass balances for 300 days of operation. The $\mathrm{COD}_{\text {Total }}$ fed was $9.3 \mathrm{~kg}$ and the start inoculum was $0.9 \mathrm{~kg}$, which was subtracted from the reactor COD. The $\mathrm{P}_{\text {Total }}$ fed was $127 \mathrm{~g}$ and the start inoculum was $34 \mathrm{~g}$, which was subtracted from the $\mathrm{P}$ in the reactor. TSS (c) and VSS (d) concentrations in the inoculum and the sludge bed over time.

\subsubsection{Sludge bed particle size distribution}

The TSS concentration and particle size distribution in the sludge bed of a non-mixed UASB reactor with $\mathrm{Ca}^{2+}$ addition (Figure 6.4b) studied by Cunha et al. (2018a) and of a nonmixed UASB reactor without $\mathrm{Ca}^{2+}$ addition (Figure 6.4c) studied by Tervahauta et al. (2014c) were more evenly distributed over the sludge bed height when compared to the UASB-GL reactor (Figure 6.4a). The UASB-GL reactor operated at the same temperature and similar OLR, but with longer HRT (17 to 31 days) due to the higher inflow of particulate organic matter (Figure 6.2), when compared with the mentioned UASB reactors (HRT of 7 to 8 days and approximately $6 \mathrm{gCOD}_{\mathrm{SS}} \mathrm{L}^{-1}$ ). With the $\mathrm{Ca}^{2+}$ addition, particles are generally larger, and particles $>0.4 \mathrm{~mm}$ diameter contained more $\mathrm{P}$ than without $\mathrm{Ca}^{2+}$ addition (Figure 6.4d). The concentration of $\mathrm{P}$ at the bottom of the reactor (harvesting location) is the highest for the UASB-GL reactor $\left(4.6 \pm 1.3 \mathrm{gP} \mathrm{L}^{-1}\right)$ when compared with the other reactors studied. The concentration of $\mathrm{P}$ as $\mathrm{CaP}$ granules is only slightly higher for the UASB-GL reactor $(3.2 \pm 1.1$ $\left.\mathrm{gP} \mathrm{L}^{-1}\right)$ when compared with a non-mixed UASB reactor with $\mathrm{Ca}^{2+}$ addition $\left(2.9 \pm 0.8 \mathrm{gP} \mathrm{L}^{-1}\right)$ reported by Cunha et al. (2018a), but much higher than the non-mixed UASB reactor without 
$\mathrm{Ca}^{2+}$ addition from Tervahauta et al. (2014c), indicating that both $\mathrm{Ca}^{2+}$ addition and mixing are needed.

a) UASB-GL reactor (mixed) with $\mathrm{Ca}^{2+}$ addition

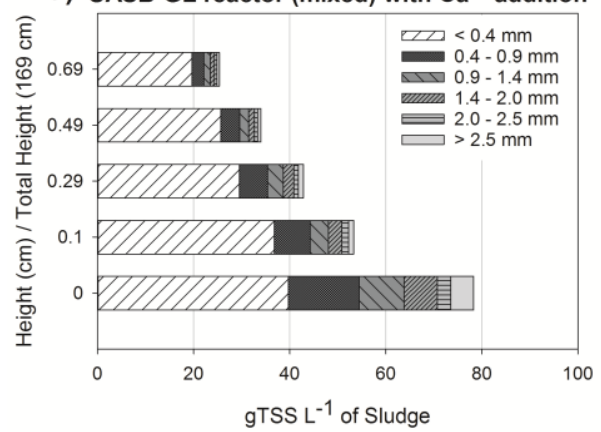

c) Non-mixed UASB reactor without $\mathrm{Ca}^{2+}$ addition

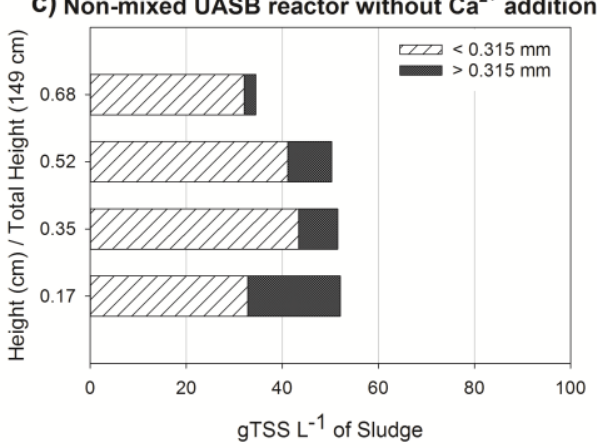

b) Non-mixed UASB reactor with $\mathrm{Ca}^{2+}$ addition

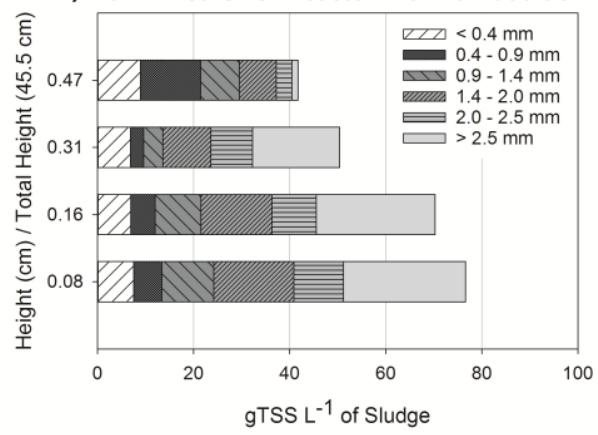

d)

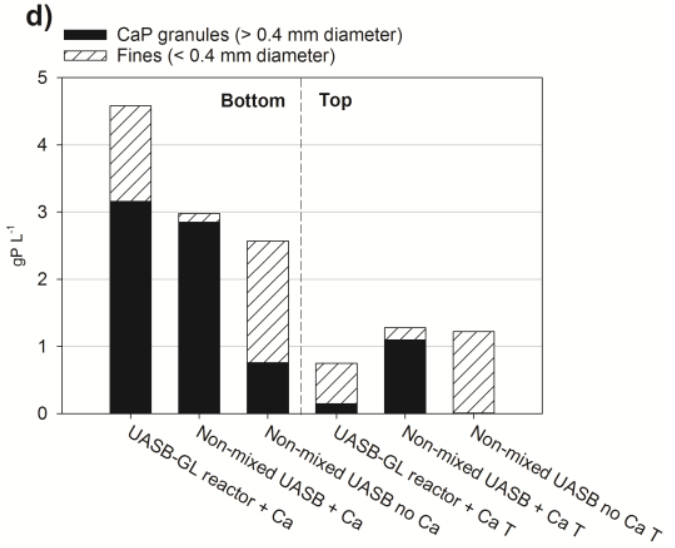

Figure 6.4 Averaged vertical distribution of TSS concentrations categorized in six size fractions (<0.4 mm, $0.4-0.9 \mathrm{~mm}, 0.9-1.4 \mathrm{~mm}, 1.4-2 \mathrm{~mm}, 2-2.5 \mathrm{~mm}$, and $>2.5 \mathrm{~mm}$ ) from sludge taken from the UASB-GL reactor (45 L) on operation days 167, 204, 258, and 300 (a), the non-mixed UASB reactor with $\mathrm{Ca}^{2+}$ addition from Cunha et al. (2018a) (b), and the non-mixed UASB reactor without $\mathrm{Ca}^{2+}$ addition from Tervahauta et al. (2014c) (c). For the latter a different size categorization was used $(<0.315 \mathrm{~mm}$ and $>0.315 \mathrm{~mm})$. Results for sludge bed size distribution of each sampling time are in Appendix C3. Average distribution of $\mathrm{P}$ as $\mathrm{CaP}$ granules $(>0.4 \mathrm{~mm}$ diameter $)$ and as fines $(<0.4 \mathrm{~mm}$ diameter $)$ at the bottom and at the top of the three reactors aforementioned (d).

\subsubsection{Elemental composition of particles}

In the UASB-GL reactor, $\mathrm{CaP}$ granules (particles > $0.4 \mathrm{~mm}$ diameter) from the bottom were on average richer in $\mathrm{P}$ when compared with $\mathrm{CaP}$ granules from the bottom of a non-mixed UASB reactor, which was also dosed with extra $\mathrm{Ca}^{2+}(77.91 \pm 5.66$ and $67.27 \pm$ $9.12 \mathrm{mgP} \mathrm{gTSS}^{-1}$, respectively) (Figure 6.5). Average values for the UASB-GL reactor are based on samples taken on operation days 167, 204, 258, and 300. Particles $>0.4$ mm diameter contained substantially more $\mathrm{P}$ than smaller particles $(<0.4 \mathrm{~mm}$ diameter $)$ in both reactors 
(Figure 6.5). The magnesium concentration was $<0.5 \mathrm{wt} \%$ for all size fractions of both reactors (results not shown).

Comparing $\mathrm{CaP}$ granules from the GL mixed with non-mixed reactors we find that the average $\mathrm{Ca}$ to $\mathrm{P}$ molar ratio $(2.0 \pm 0.2)$ in $\mathrm{CaP}$ granules $(>0.4 \mathrm{~mm}$ diameter) from the bottom of the UASB-GL reactor was similar to $\mathrm{CaP}$ granules from the bottom a conventional UASB reactor $(1.9 \pm 0.1)$ (Cunha et al., 2018a). The samples of CaP granules $(>0.4 \mathrm{~mm}$ diameter) from the bottom of the UASB-GL reactor contained considerably less VSS than from the bottom of a non-mixed UASB reactor $\left(17.25 \pm 4.73 \mathrm{gVSS} \mathrm{L}^{-1}\right.$, representing a VSS/TSS ratio of $0.42 \pm 0.24$, and $32.15 \pm 2.74 \mathrm{gVSS} \mathrm{L}^{-1}$, representing a VSS/TSS ratio of $0.76 \pm 0.14$, respectively). Comparing fines from the GL mixed reactor with the CaP granules we find that particles with a diameter between 0.4 and $2.5 \mathrm{~mm}$ were the most inorganic in both reactors. Visually, the SEM image in Figure 6.6a shows that a representative CaP granule from the UASB-GL reactor has a thinner outer biofilm $(20 \mu \mathrm{m})$ when compared to $\mathrm{CaP}$ granules from a non-mixed UASB reactor (Cunha et al., 2018b). Furthermore, EDX of a fine (Figure 6.6d) showed $\mathrm{Mg}$ containing precipitates while in the EDX of a larger particle (Figure 6.6b) only CaP precipitates (green) could be observed.

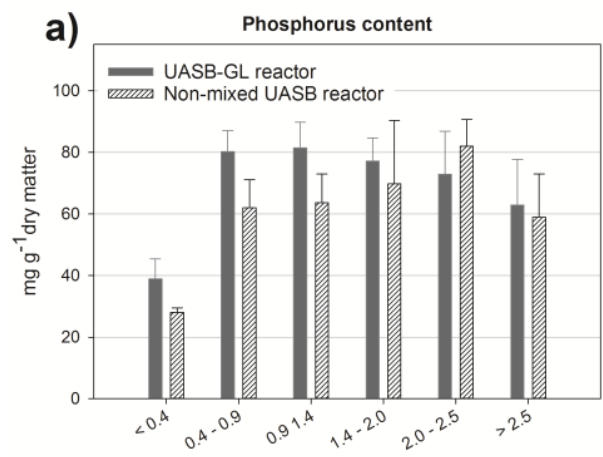

Diameter $(\mathrm{mm})$

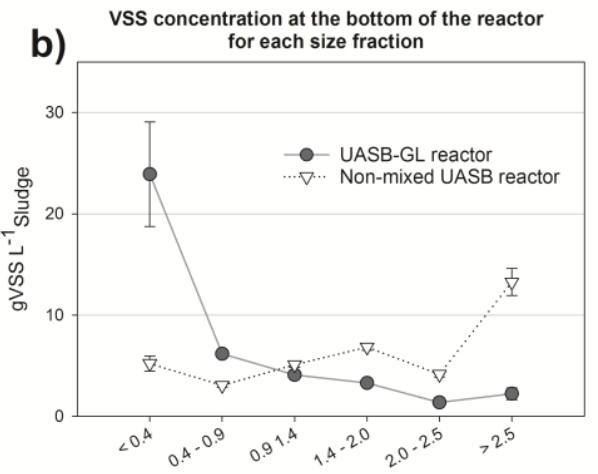

Diameter $(\mathrm{mm})$

Figure 6.5 Average P content and VSS concentration for different sized particles from the bottom of the UASB-GL reactor (a) and the bottom of the non-mixed UASB reactor with $\mathrm{Ca}^{2+}$ addition reported in Cunha et al. (2018a) (b). Average values for the UASB-GL reactor are from samples taken on operation days 167, 204, 258, and 300. Results for each sampling day are in Appendix C4. 


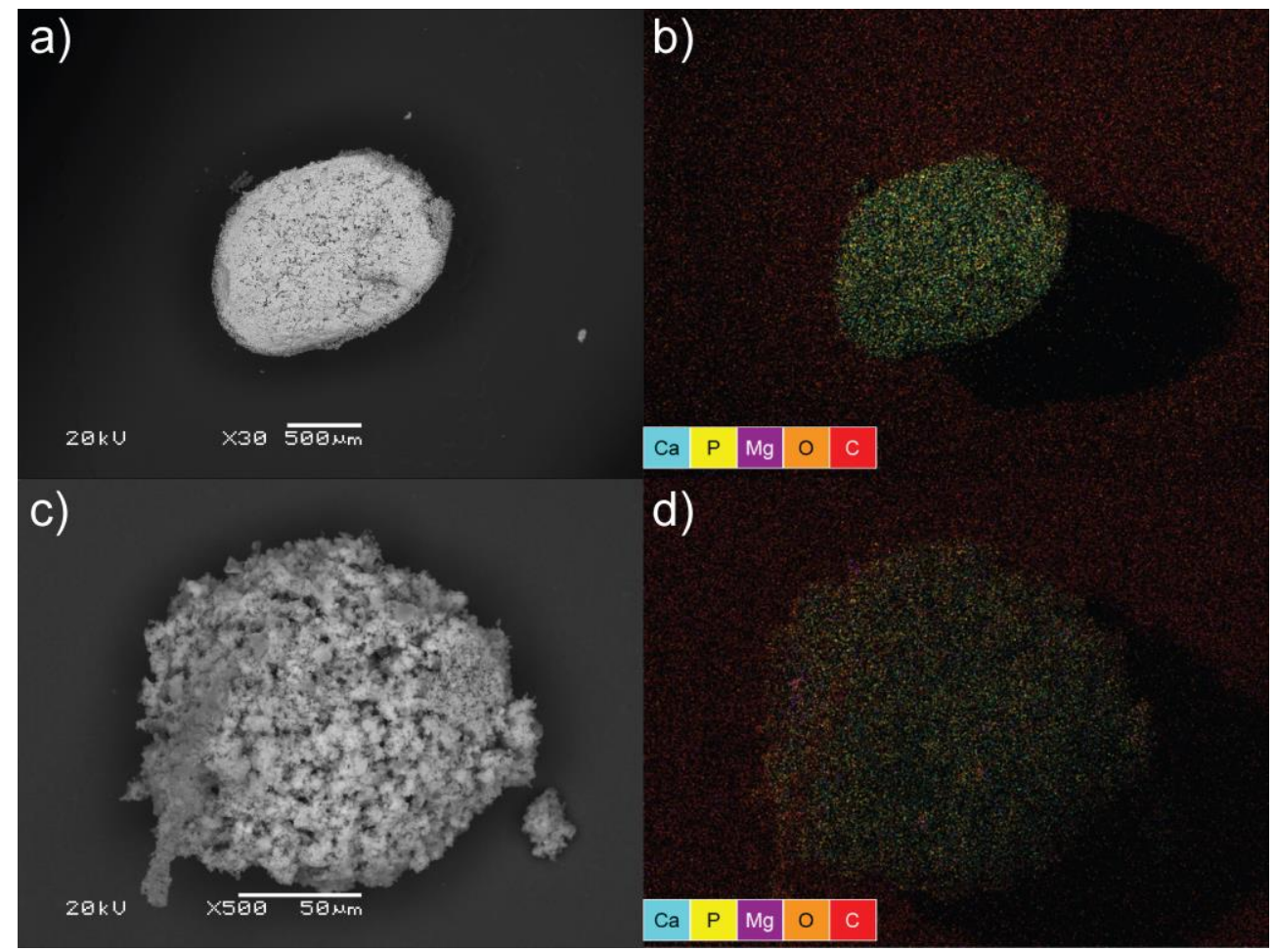

Figure 6.6 Scanning electron microscope (SEM) images of particles with approximately 1 (a) and 0.1 (c) $\mathrm{mm}$ in diameter coupled with the respective energy dispersive X-ray (EDX) elemental map ( $b$ and d). The color in the EDX images represents the described elements where the overlay of $\mathrm{Ca}\left(\right.$ cyan) and $\mathrm{P}$ (yellow) give $\mathrm{Ca}_{\mathrm{x}}\left(\mathrm{PO}_{4}\right)_{\mathrm{y}}$ (green).

\subsubsection{Flow characteristics in UASB-GL reactor}

The liquid flow in the UASB-GL reactor was mainly influenced by the $\mathrm{N}_{2}$ injection around the riser (Figure 6.7a). The calculated (COMSOL model) velocities presented in Figure 6.7 are reached after 20 seconds of $\mathrm{N}_{2}$ injection and remained stable afterward. The liquid flow was directed upwards inside the riser with a velocity up to $18 \mathrm{~m} \mathrm{~h}^{-1}$. Outside the riser (downcomer) the liquid velocity was 10 times lower than inside the riser. The upward force consequent of the $\mathrm{N}_{2}$ injection dragged liquid into the riser within a radius of $2.5 \mathrm{~cm}$ radius from the bottom of the riser (Figure 6.7b). The very bottom of the cone was unmixed, due to the high TSS concentration and consequent high fluid viscosity $(\sim 1 \mathrm{~Pa}$ s for a mixed liquor suspended solids (MLSS) containing $60 \mathrm{gTSS} \mathrm{L}^{-1}$ ) which was not considered during the designing phase. 
a)

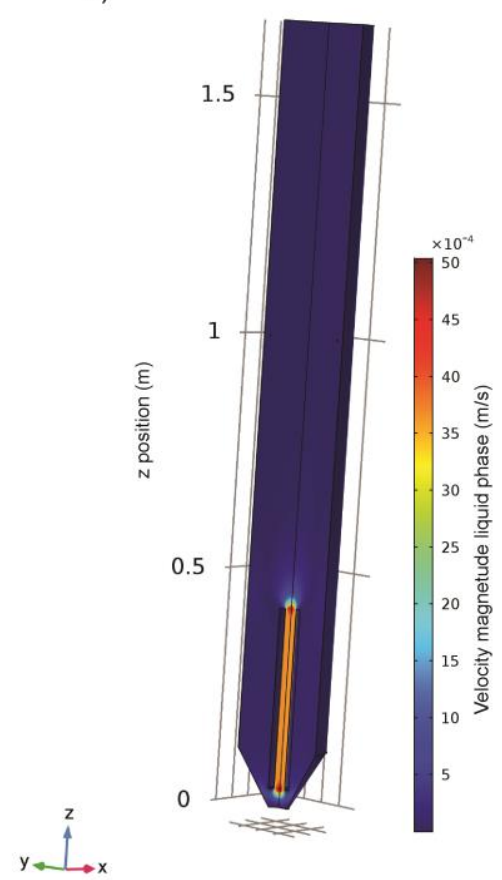

b)

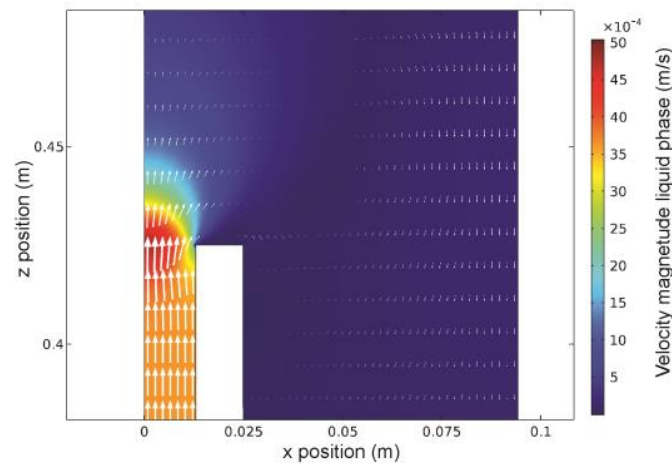

c)

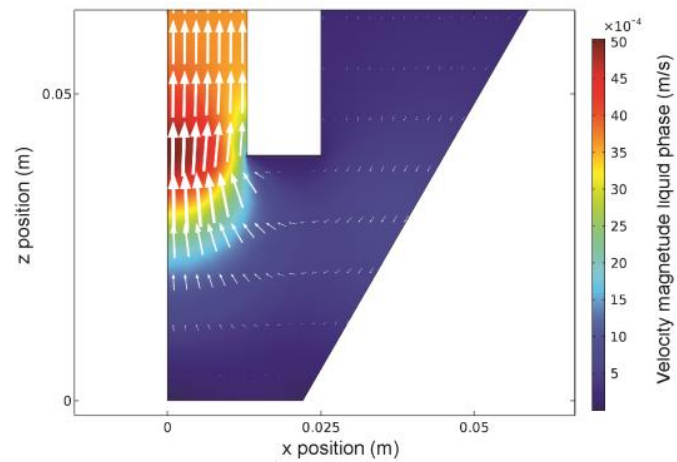

Figure 6.7 Surface graphs of the liquid velocities and direction in the UASB-GL reactor presented by color and arrows, respectively. The simulation of the liquid motion was performed using the Multiphysics software COMSOL. Image a) gives an overview of the true to scale reactor in a 3D partial cut view, and images b) and c) are 2D zoom-ins of the entrance and exit of the riser, respectively.

\subsection{Discussion}

\subsubsection{Influence of gas-lift mixing on the treatment of BW}

The implementation of the gas-lift principle in a UASB reactor did not affect the anaerobic treatment efficiency (Table 6.1). The difference in removal efficiency of COD and $\mathrm{P}$ between the UASB-GL reactor and previous reports on non-mixed UASB reactors treating BW is not significant. Unfortunately, the solid content in BW during operation of the UASBGL reactor $\left(16 \pm 6 \mathrm{gCOD}_{\mathrm{Ss}} \mathrm{L}^{-1}\right)$ was much higher than during the operation of the UASB reactors from Cunha et al. (2018a) and Graaff et al. (2010) $\left(6 \pm 2\right.$ and $5 \pm 3$ gCOD Ss L $^{-1}$, respectively). To compensate for the higher solid content, the HRT for the UASB-GL reactor was extended to assure sufficient SRT and hydrolysis. The OLR in the UASB-GL reactor (0.96 gCOD L ${ }^{-1} \mathrm{~d}^{-1}$ in phase 3 ) was similar to UASB reactors tested in previous studies without $\mathrm{Ca}^{2+}$ addition (0.9 to $1 \mathrm{gCOD} \mathrm{L}^{-1} \mathrm{~d}^{-1}$ ) (Graaff et al., 2010; Tervahauta et al., 2014a). The lower $\mathrm{CH}_{4}$ production, when compared to previous studies for anaerobic BW treatment, is most likely due 
to the lower biodegradability of the BW fed to the UASB-GL reactor. This is supported by the higher sludge production obtained in the UASB-GL reactor $\left(0.126 \mathrm{gVSS}_{\mathrm{gCOD}} \mathrm{Bw}^{-1}\right)$ when compared to the conventional UASB reactor $\left(0.09 \mathrm{gVSS}_{\mathrm{gCOD}} \mathrm{Bw}^{-1}\right)$ reported in Cunha et al. (2018a). Thus, the effect of the mixing on the $\mathrm{CH}_{4}$ production was not conclusive. Earlier studies showed that $\mathrm{Ca}^{2+}$ addition and increased mixing stimulated anaerobic digestion, by enhancing retention of solids in a UASB reactor and increasing the mass transfer of substances within the sludge bed, respectively (Das et al., 2018; Ghangrekar et al., 2005; Saner et al., 2016).

By adding $\mathrm{Ca}^{2+}$ to the UASB-GL reactor, the increased retention of solids and the production of $\mathrm{CaP}$ granules in the sludge bed could have decreased the diffusive mass transport, resulting in lower treatment functionality by cementation of the bottom of the reactor (Ahmadi-Pirlou et al., 2017; Batstone et al., 2002b; Li et al., 2012; Liu and Tay, 2004). The $\mathrm{Ca}^{2+}$ injection in the upper end of the riser and the mixing enhanced the spread of $\mathrm{Ca}^{2+}$ throughout the reactor, assuring improved removal of $\mathrm{PO}_{4}{ }^{3-}$ by stimulation of $\mathrm{Ca}_{\mathrm{x}}\left(\mathrm{PO}_{4}\right)_{\mathrm{y}}$ precipitation, avoiding cementation of the sludge bed, and stimulating biomass aggregation and retention in the reactor. Thus, the combination of principles from bubble column bioreactors, industrial crystallizers, and the high retention of solids in UASB reactors enabled the efficient $\mathrm{PO}_{4}{ }^{3-}$ precipitation (73 to $88 \%$ ) and retention of particulate $\mathrm{P}$ in the reactor $(90 \%)$. Compared to mechanical mixing alternatives, gas-induced mixing exerts low shear stress on the mixed media, and therefore, it lowers the risk of microbial activity inhibition, breakage of precipitates, and disruption of CaP bio granulation (Laspidou and Rittmann, 2004; Rochex et al., 2008; Sindall et al., 2013; Soare et al., 2012).

\subsubsection{Effect of gas-lift on the particle size distribution of the sludge bed}

The gas-lift mixing created a significantly different sludge bed when compared to non-mixed UASB reactors treating BW (Figure 6.4). Fluidization at the bottom resulted in a more pronounced gradient of solids, with a TSS concentration of $73 \mathrm{~g} \mathrm{~L}^{-1}$ sludge at the bottom to $31 \mathrm{~g} \mathrm{~L}^{-1}$ sludge on the top during phase 3. Wang et al. (2018) showed a similar distribution of solids in a UASB reactor treating BW and kitchen waste with a frequent injection of recycled biogas. The exerted shear stress on the solid agglomerates induced a higher selectivity for denser and faster settling particles, especially at the bottom of the UASB-GL reactor, where most of the mixing occurred when compared to non-mixed UASB reactors (Batstone et al., 2005; Daintree and Biggs, 2010; Gjaltema et al., 1995; Kwok et al., 1998). Additionally, the movement in the sludge bed allowed particles to rearrange and biogas to escape, forming an overall denser sludge bed by enhancing compactness of solids (Mahmoud et al., 2003; Shin 
and Paik, 1990). The settling of larger $\mathrm{P}$ containing particles enables purging excess sludge at the upper part of the sludge bed (tap 4) with low P content, maximizing the P harvesting at the bottom of the reactor (Figure 6.4d). In non-mixed UASB reactors, the percolation of small particles through the spacing between larger particles enhanced the packing effect and hindered sedimentation of the densest and largest particles to the bottom as shown in Figure 6.4 (Cunha et al., 2018a; Landman and White, 1994; Langerak et al., 1998).

\subsubsection{Influence of the fluid properties on the mixing efficiency}

The viscosity of the sludge bed (MLSS) increased from top to bottom, along with the concentration of solids (Figure 6.4). Bollon et al. (2013) showed that the diffusive mass transfer is decreasing substantially in the range of 0 to $15 \%$ with increasing solid content, due to the elevated viscosity. Locally increased $\mathrm{PO}_{4}{ }^{3-}$ and $\mathrm{Ca}^{2+}$ concentrations occurred at the bottom of a non-mixed UASB reactor, leading to unwanted $\mathrm{Ca}_{\mathrm{x}}\left(\mathrm{PO}_{4}\right)_{\mathrm{y}}$ precipitation at the wall (Cunha et al., 2018a). Due to the gradient in viscosity, the upper part of the sludge bed, which contained fewer solids, is more susceptible to mixing than the lower part (Tchobanoglous et al., 2004). In the model (Figure 6.7), the viscosity was assumed constant in the entire reactor. Thus, the modeled liquid velocity in the upper part of the reactor is likely underestimated. The expansion of the sludge bed by the injection of gas could lead to washout of solids from the GLS when the reactor volume is not sufficient. Therefore, the expansion of the sludge bed when gas is injected should be taken into consideration for sizing the reactor, preventing washout of solids (Wang et al., 2018).

The upward drag force (Figure 6.7) formed by the loop was not sufficient to efficiently lift fine particles $(<0.4 \mathrm{~mm}$ diameter) from the very bottom of the reactor, because of the high solids concentration (Figure 6.4) and increased viscosity, reducing the liquid velocity in the riser from $70 \mathrm{~m} \mathrm{~h}^{-1}$, which was the designed velocity, to $18 \mathrm{~m} \mathrm{~h}^{-1}$. Thus, the riser geometry and gas flow for the recirculation should be optimized to improve the upward drag force at the bottom of the reactor. According to the COMSOL model, the critical parameters are the volumetric gas flow $\left(Q, \mathrm{ml} \mathrm{min}^{-1}\right)$, the distance from the bottom of the riser to the bottom of the reactor $\left(h_{r}, \mathrm{~cm}\right)$, and the diameter of the riser $\left(d_{r}, \mathrm{~cm}\right)$. In order to increase the lifting drag force, a higher $Q$ and a shorter $h_{r}$ are needed. The increase in $Q$ increases the difference in gas hold up between the riser and the downcomer, resulting in a higher upflow velocity of the liquid in the riser, stronger lifting force, and larger upward dragging field. The shorter $h_{r}$ increases the proximity between the upward dragging field and the bottom of the reactor, rising the local lifting force. A smaller $d_{r}$ would increase the upflow velocity of the 
liquid in the riser, but decrease the force and area of the upward dragging field. Additionally, the $\mathrm{N}_{2}$ gas used for internal recirculation in this study could be replaced by produced biogas, which is readily available during anaerobic digestion of BW. Then, by controlling the pressure build-up, the excess of biogas is purged from the system ans recovered.

\subsubsection{Effect of mixing on the growth mechanism of CaP granules}

Particles $<0.4 \mathrm{~mm}$ diameter represented $67 \%$ of the whole sludge bed in the UASBGL reactor and contained $3.9 \mathrm{wt} \% \mathrm{P}$, while only $10 \%$ and $2.8 \mathrm{wt} \% \mathrm{P}$ in a non-mixed UASB reactor at comparable $\mathrm{Ca}^{2+}$ inflow, respectively (Cunha et al., 2018a), indicating that the shear stress decreased the growth of larger organic $\mathrm{CaP}$ granules and increased the number of $\mathrm{P}$ fines in the reactor and the $\mathrm{P}$ content in $\mathrm{CaP}$ granules (Figure 6.4 and Figure 6.5). The lower density and strength of the outer biofilm in $\mathrm{CaP}$ granules (> $0.4 \mathrm{~mm}$ diameter), when compared to the inorganic core, resulted in reduced organic content in $\mathrm{CaP}$ granules produced in the UASBGL reactor (Figure 6.5b).

Gjaltema et al. (1995) found that the main reason for biofilm detachment from carriers in air-lift reactors was the interaction between particles, leading to abrasion or breakage. Particle interactions in the UASB-GL reactor are mainly expected in the loop around the riser, where both detachment mechanisms (abrasion and breakage) are expected. Furthermore, Kwok et al. (1998) reported that the density and thickness of the biofilm in carrier particles in an air-lift reactor depend on the detachment force and the surface substrate loading. High substrate loading and low shear force lead to thick and less dense biofilms, whereas high shear force and low substrate loading lead to thin and dense biofilms. The biofilm thickness of the representative $\mathrm{CaP}$ granule from the mixed UASB reactor is significantly lower $(\sim 20 \mu \mathrm{m})$ compared to the $\mathrm{CaP}$ granules from non-mixed UASB reactor, due to the increased detachment force exerted on the biofilm; the substrate loading was comparable in both reactors. $\mathrm{CaP}$ granules from the UASB-GL reactor generally had a single inorganic core, while CaP granules from a non-mixed UASB reactor frequently contained several inorganic clusters in the core (Cunha et al., 2018a). This can be explained by the higher shear force applied, promoting precipitation of $\mathrm{Ca}_{\mathrm{x}}\left(\mathrm{PO}_{4}\right)_{\mathrm{y}}$ on the surface of the core over nucleation in the outer biofilm. Thus, by controlling the gas flow, according to the desired liquid upflow velocity in the riser, the size and purity of harvested $\mathrm{CaP}$ granules can be steered during their formation and maturation. 


\subsubsection{Effect of mixing on harvested CaP granules}

Harvested CaP granules (> $0.4 \mathrm{~mm}$ diameter) from the mixed UASB contained $7.8 \pm$ $0.6 \mathrm{wt} \%$ of $\mathrm{P}$, which is a higher average than $\mathrm{CaP}$ granules taken from a non-mixed UASB reactor $(6.7 \pm 1.1 \mathrm{wt} \%$ of $\mathrm{P})$, indicating that the gas-lift mixing enhanced the $\mathrm{Ca}_{\mathrm{x}}\left(\mathrm{PO}_{4}\right)_{\mathrm{y}}$ content in the granules (Cunha et al., 2018a). Since the Mg content was < $0.5 \mathrm{wt} \%$ (results not shown), struvite is not expected to be present in the granules. The $\mathrm{Ca}$ to $\mathrm{P}$ molar ratio in $\mathrm{CaP}$ granules (> $0.4 \mathrm{~mm}$ diameter) increased on average from $1.80 \pm 0.03$ on operation day 167 to $2.20 \pm$ 0.11 on day 258 (Appendix C4). The higher Ca to $\mathrm{P}$ molar ratio in $\mathrm{CaP}$ granules on day 258 is explained by the higher $\mathrm{HCO}_{3}{ }^{-}$concentration in $\mathrm{BW}$ during the preceding period, resulting in higher bulk $\mathrm{pH}(>7.5)$ and precipitation of $\mathrm{CaCO}_{3}$. The role of the bulk $\mathrm{pH}$ on $\mathrm{CaP}$ bio granulation was previously explained by Cunha et al. (2018b). For bulk pH higher than 7.5, $\mathrm{CaCO}_{3}$ precipitation is kinetically favored, although HAP is still the thermodynamically most stable phase (Lei et al., 2018; Rokidi et al., 2011; Schiller and Epple, 2003). Over time, the formed $\mathrm{CaCO}_{3}$ will most likely dissolve again, providing $\mathrm{Ca}^{2+}$ for $\mathrm{Ca}_{\mathrm{x}}\left(\mathrm{PO}_{4}\right)_{y}$ precipitation (Rokidi et al., 2011; Song et al., 2006b). The increase in $\mathrm{HCO}_{3}{ }^{-}$and bulk $\mathrm{pH}$ during phase 2 was considerable (Figure 6.2), increasing the co-precipitation of $\mathrm{CaCO}_{3}$ from $8 \%$ on day 167 to $26 \%$ on day 258 . Therefore, bulk $\mathrm{pH}$ and $\mathrm{HCO}_{3}{ }^{-}$concentration in $\mathrm{BW}$, which might be related to organic composition and storage time, are critical parameters for the purity of the harvested $\mathrm{CaP}$ granules. During phase 2 the concentration of $\mathrm{COD}_{\mathrm{SS}}$ represented only $53 \%$ of the $\mathrm{COD}_{\text {Total }}$, which might have decreased the formation of $\mathrm{H}_{2}$ and $\mathrm{H}^{+}$and consequently the transformation of $\mathrm{HCO}_{3}{ }^{-}$during hydrogenotrophic methanogenesis. During phase 1 and 3, the $\mathrm{COD}_{\mathrm{SS}}$ and $\mathrm{COD}_{\text {Total }}$ ratio was $60 \%$ and $78 \%$, respectively.

\subsubsection{Phosphorus recovery potential in the UASB-GL reactor}

$\mathrm{Ca}^{2+}$ addition is a key factor in the recovery of $\mathrm{P}$ as $\mathrm{CaP}$ granules, as in $\mathrm{BW}$ there is not enough $\mathrm{Ca}$ to trap all the $\mathrm{P}$. Mixing and reactor design can enhance this potential by improving the quality and concentration of $\mathrm{CaP}$ granules at the harvesting location. The concentration of $\mathrm{P}$ at the harvesting location in the UASB-GL reactor was $4.58 \pm 1.34 \mathrm{gP} \mathrm{L}^{-}$ ${ }^{1}$ sludge , from which $70 \%$ was as $\mathrm{CaP}$ granules (>0.4 mm diameter) and only $30 \%$ was as fine particles (< $0.4 \mathrm{~mm}$ diameter). According to the $\mathrm{P}$ mass balance (Figure 6.3), 29\% of the $\mathrm{P}$ fed was found as CaP granules after 300 days.

Samples were taken every two months at five locations in the reactor to evaluate the effect of mixing on particle size distribution of the sludge bed over time. The frequent sampling from all the sampling points and low mixing efficiency reduced the $\mathrm{P}$ recovery efficiency as $\mathrm{CaP}$ granules, due to the harvesting of $\mathrm{P}$ from the middle of the reactor and harvesting of $\mathrm{P}$ as 
particles $<0.4 \mathrm{~mm}$ diameter. The $\mathrm{P}$ recovery efficiency can be enhanced by increasing the retention time of $\mathrm{P}$ at the bottom of the reactor while wasting excess of sludge (VSS) in the upper part of the sludge bed. During phase 3, the calculated SRT of VSS for the bottom of the reactor was 1.7 times higher than the top part (Table 6.1), because more solids were purged and washout from the top. Furthermore, the retention time of $\mathrm{CaP}$ granules in the reactor (578 days) was 1.6 times higher than the retention time of total $\mathrm{P}$ (353 days), using eq. 6.2 with the mass of P instead of VSS during phase 3. Thus, the decoupling of VSS SRT from top and bottom of the reactor and the efficient lifting of smaller particles from the bottom are essential to enable concentration and maturation of $\mathrm{CaP}$ granules at the harvesting location.

Considering the measured daily sludge production during phase $3\left(4.3 \mathrm{gVSS} \mathrm{d}^{-1}\right)$, the estimated amount of $\mathrm{P}$ wasted with the purged sludge from the top part of the reactor is 140 $\mathrm{mgP} \mathrm{d}^{-1}$, representing $33 \%$ of the total $\mathrm{P}$ incoming from $\mathrm{BW}$. The measured $\mathrm{P}$ content in wasted sludge is $0.03 \mathrm{gP} \mathrm{g}^{-1}$ of VSS. Then, the remaining P $\left(226 \mathrm{mgP} \mathrm{d}^{-1}\right.$, representing $57 \%$ of the total $\mathrm{P}$ incoming from $\mathrm{BW}$ ) can be recovered as $\mathrm{CaP}$ granules at the harvesting location. Note that in average $10 \%$ of $\mathrm{P}$ in $\mathrm{BW}$ leaves the reactor with the effluent. However, for a lower sludge production (lower concentration of $\mathrm{COD}_{\mathrm{SS}}$ in the influent and higher biodegradability of organic solids) the recovery potential as $\mathrm{CaP}$ granules increases, due to the higher $\mathrm{P}$ retention time. Therefore, the recovery efficiency of CaP granules in the UASB-GL reactor can be much higher when sludge production is minimized. The mass of $\mathrm{P}$ as CaP granules in the UASB-GL reactor decreased from $71 \%$ on day 167 (phase 2) to $46 \%$ on day 300 (phase 3), most likely due to oversampling during phase 3 .

$\mathrm{CaP}$ granules from the UASB-GL reactor are a promising recovered $\mathrm{P}$ product to replace phosphate rock in the fertilizer industry or applied as direct fertilizer (European Commission, 2016). The UASB-GL reactor enhanced the average $\mathrm{P}$ content in CaP granules from $15 \mathrm{wt} \% \mathrm{P}_{2} \mathrm{O}_{5}$ in a non-mixed UASB reactor to $18 \mathrm{wt} \% \mathrm{P}_{2} \mathrm{O}_{5}$ close to the minimum of 25 $\mathrm{wt} \% \mathrm{P}_{2} \mathrm{O}_{5}$ requirement of the phosphate industry. The minimum of $25 \mathrm{wt} \% \mathrm{P}_{2} \mathrm{O}_{5}$ can be achieved by enhancing the hydrodynamic lifting force (shear stress) of the loop at the bottom of the reactor, which can potentially decrease the organic content in CaP granules, and consequently, enhance the $\mathrm{P}$ content. Also, recovered products from $\mathrm{BW}$ will have a low heavy metal content (Tervahauta et al., 2014b). Therefore, the application of CaP bio granulation using UASB-GL reactor in the source separation sanitation is an opportunity to improve the local $\mathrm{P}$ recovery and to enable the circular and sustainable use of $\mathrm{P}$ from human waste. 


\subsection{Conclusions}

The integration of gas-lift mixing in a UASB reactor (UASB-GL reactor) with additional $\mathrm{Ca}^{2+}$ resulted in a harvesting location at the bottom of the reactor, yielding $\mathrm{CaP}$ granules (> $0.4 \mathrm{~mm}$ diameter), while at the top of the reactor the total $\mathrm{P}$ concentration was reduced, enabling purge of excess VSS (sludge) at low expense of $\mathrm{P}$.

- P removal was above $90 \%$ during stable operation at a loading rate of $0.96 \pm 0.30$ gCOD L $\mathrm{L}^{-1} \mathrm{~d}^{-1}$ at $25^{\circ} \mathrm{C}$.

- The UASB-GL reactor exhibited high stability in treatment performance even with substantial fluctuations in the influent suspended material $\left(\mathrm{COD}_{\mathrm{SS}}\right)$.

- The average $\mathrm{P}$ content in recovered $\mathrm{CaP}$ granules (>0.4 mm diameter) at the bottom of the reactor increased $16 \%$, due to the shear of the gas-lift mixing.

- The P as CaP granules represented $71 \%$ of the total P in the UASB-GL reactor on operation day 167 , but due to the high sludge production during phase 3 and oversampling it decreased to $46 \%$ after 300 days of operation.

- The recovery efficiency as CaP granules in the UASB-GL reactor decreases with the reduction in solids retention time (increase in sludge production).

- The critical geometric parameters for the lifting force field at the bottom of the reactor are the injected gas volumetric flow $(Q)$ and the heigth of the riser with respect to the bottom of the reactor $\left(h_{r}\right)$. 


\section{Chapter 7. Characterization of recovered calcium phosphate granules from black water}

J. R. Cunha, C. Schott, R. D. van der Weijden, L. Hernández Leal, G. Zeeman, C. J. N. Buisman

\section{Calcium phosphate granules}

from anaerobic treatment of source separated black water

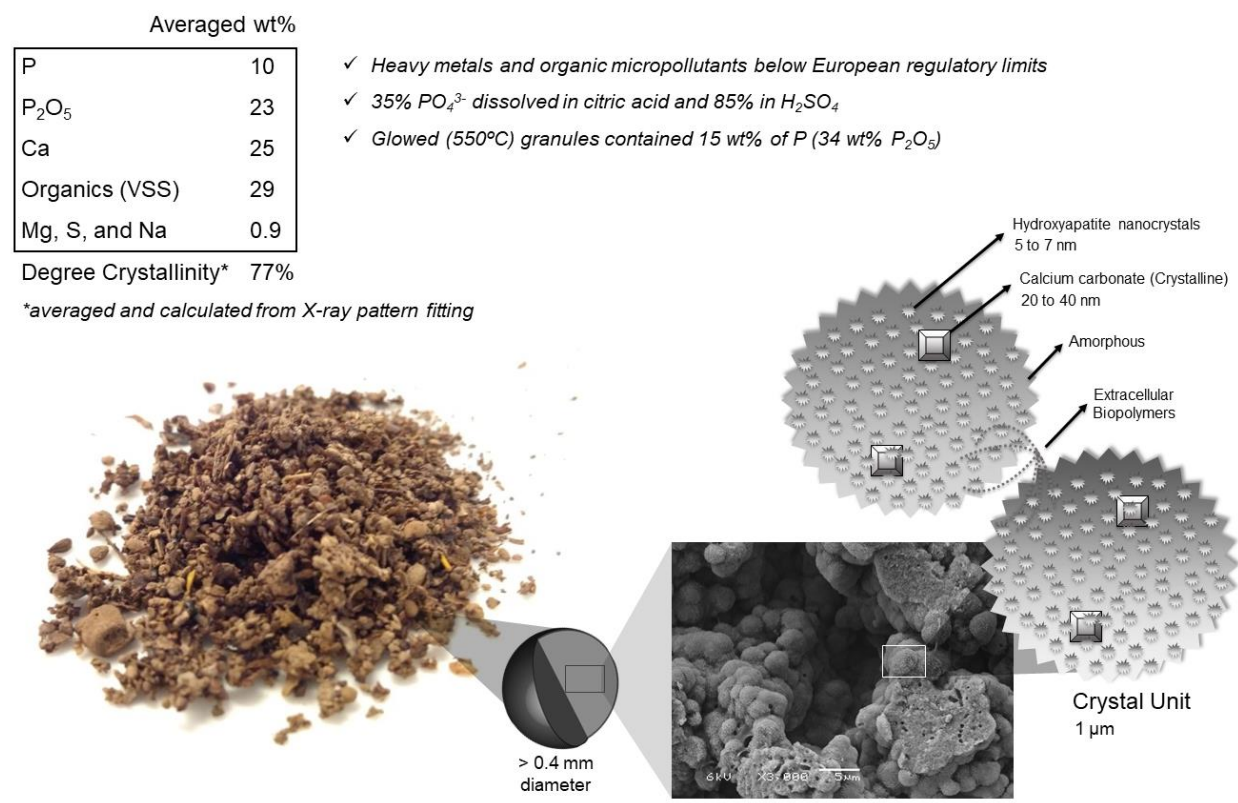




\begin{abstract}
Phosphate is essential for food production. However, phosphate rock, which is the main natural source, is becoming worse in quality, regarding heavy metals and radioactive compounds, due to depletion of reserves. Marketable phosphate contains more than $13 \mathrm{wt} \% \mathrm{P}$, but run-of-mine phosphate rock is of lower grade ( 8 to $11 \mathrm{wt} \% \mathrm{P}$ ), due to scarcity. In this study we assessed calcium phosphate $(\mathrm{CaP})$ granules, a potential substitute for phosphate rock, produced during anaerobic treatment of vacuum collected black water (feces and urine, BW). The quality assessment was based on elemental composition (macro nutrients and heavy metals), crystallography and morphology analyses, dissolution tests, and quantification of micropollutants. CaP granules contained $10 \mathrm{wt} \% \mathrm{P}$, from which $35 \%$ was dissolved within 5 min in citric acid and $85 \%$ in $\mathrm{H}_{2} \mathrm{SO}_{4}$. The glowing of the $\mathrm{CaP}$ granules increased the $\mathrm{P}$ content to $15 \mathrm{wt} \%$, by eliminating the remaining organics (29\%), pathogens and organic micropollutants. Heavy metals $(\mathrm{Cu}, \mathrm{Zn}, \mathrm{Cr}, \mathrm{Ni}, \mathrm{Cd}, \mathrm{As}$, and $\mathrm{Pb})$ and organic micropollutants in $\mathrm{CaP}$ granules were below the Dutch and European regulatory limits for application as a direct fertilizer. Moreover, glowed $\mathrm{CaP}$ granules complied with the requirements for use in the fertilizer industry. At the current process conditions, $\mathrm{CaP}$ granules produced from $\mathrm{BW}$ in the Netherlands can potentially replace $12 \%$ of the phosphate rock input in agriculture.
\end{abstract}




\subsection{Introduction}

Phosphorus (P) is a key component in crop fertilization and consequently, in food production for humankind (Cordell et al., 2009). Sedimentary phosphate rock, which is the major source of $\mathrm{P}$ for crop fertilization, is finite and depleting, but also becoming lower in quality, regarding heavy metals and radioactive content (Aydin et al., 2010; Kratz et al., 2016). Marketable phosphate contains more than $13 \mathrm{wt} \% \mathrm{P}$, but run-of-mine phosphate rock is of lower grade (8 to $11 \mathrm{wt} \% \mathrm{P}$ ), due to scarcity (Abouzeid, 2008). The distribution of phosphate rock could become a geopolitical risk.

Considering the global input of mineral $\mathrm{P}$ as fertilizer (14 Mt year ${ }^{-1}$ in 2005), 21\% of the $\mathrm{P}$ (3 Mt year-1) is lost to the environment as human excreta (Cordell et al., 2009; Elser and Bennett, 2011). The current use of $\mathrm{P}$ as phosphate rock can be considered as linear, as at the present date no recoverable product containing $\mathrm{P}$ can economically replace phosphate rock for production of fertilizer (Desmidt et al., 2015; Nättorp et al., 2017). This is caused by low economic efficiency of the current $\mathrm{P}$ recovery technologies and centralized sewage collection, which leads to contamination of the recovered products with heavy metals (Desmidt et al., 2015; Houhou et al., 2009; Rule et al., 2006; Schipper et al., 2001). Therefore, for enabling the substitution of phosphate rock by recovered $\mathrm{P}$, attention should be given to economic and safety aspects, besides the recovery efficiency, the concentration of $\mathrm{P}$, and the percentage of bioavailable phosphate $\left(\mathrm{PO}_{4}{ }^{3-}\right)$.

Current technologies for $\mathrm{P}$ recovery focus on chemical precipitation of struvite $\left(\mathrm{MgNH}_{4} \mathrm{PO}_{4} \cdot 6 \mathrm{H}_{2} \mathrm{O}\right)$ and calcium phosphate $\left(\mathrm{Ca}_{\mathrm{x}}\left(\mathrm{PO}_{4}\right)_{\mathrm{y}}\right)$ in anaerobic effluent, the $\mathrm{P}$ rich side stream of biological phosphorus removal plants, the filtrate from sewage sludge (SS) dewatering, and the leachate from acidified sewage sludge ash (SSA) (Desmidt et al., 2015). $\mathrm{Ca}_{\mathrm{x}}\left(\mathrm{PO}_{4}\right)_{\mathrm{y}}$ can replace phosphate rock for fertilizer production, but struvite cannot because of the ammonium, which leads to gas scrubbing problems by formation of nitrous gas (Schipper et al., 2001). Both $\mathrm{Ca}_{\mathrm{x}}\left(\mathrm{PO}_{4}\right)_{\mathrm{y}}$ and struvite can be used directly as a fertilizer, but when produced from waste streams the potential presence of heavy metals, organic micropollutants, and pathogens arises concerns. Other option for P reuse is the direct use of SS and compost as organic fertilizer or as replacement of phosphate rock for production of water-soluble phosphate via incineration (SSA), but the high concentration of heavy metals generally measured in sewage sludge limits their use (Desmidt et al., 2015; European Commission, 2016; European Parliament, 1986). 
Source separation of household streams enables the anaerobic treatment of vacuum collected black water (faeces and urine, BW) (Graaff et al., 2010). Due to the vacuum collection ( 0.25 to $1 \mathrm{~L}$ water per flush), BW is highly concentrated in $\mathrm{P}$, nitrogen $(\mathrm{N})$, and organic matter ( 0.15 to $0.30 \mathrm{gP} \mathrm{L}^{-1}, 1$ to $1.4 \mathrm{gNH}_{4}{ }^{+} \mathrm{L}^{-1}$ and 10 to $15 \mathrm{gCOD} \mathrm{L}^{-1}$, respectively), and therefore, it has high potential for recovery of energy and nutrients (Graaff et al., 2011a). Previously, Tervahauta et al. (2014c) described the simultaneous production of calcium phosphate granules (CaP granules) and methane $\left(\mathrm{CH}_{4}\right)$ during anaerobic treatment of $\mathrm{BW}$ in an upflow anaerobic sludge blanket (UASB) reactor, where $2 \%$ of the total incoming P could be recovered. Cunha et al. (2018a) stimulated the formation and growth of $\mathrm{CaP}$ granules by adding $\mathrm{Ca}^{2+}$ at the bottom of the UASB reactor, increasing the $\mathrm{P}$ recovery as $\mathrm{CaP}$ granules to at least $31 \%$ while removing $89 \%$ of the P in BW (Cunha et al., 2018a). Results of recent research, combining UASB and gas-lift technologies (UASB-GL reactor), show an increased $\mathrm{P}$ content in the harvested CaP granules (from 5.6 to 7.8 wt\%) (Chapter 6; Cunha et al., 2018a).

In this study, the potential of $\mathrm{CaP}$ granules as fertilizer is discussed. The granules were harvested from the UASB-GL during the treatment of source separated BW. Firstly, the crystal and morphological properties of $\mathrm{CaP}$ granules are analysed via X-ray diffraction (XRD) and scanning electron microscope (SEM) coupled with energy dispersive X-ray (EDX). Then, concentrations of heavy metals and organic micropollutants are analytically assessed. Finally, the potential bioavailability of $\mathrm{P}$ in $\mathrm{CaP}$ granules is assessed by dissolution tests in citric acid, distilled water, and sequential extraction with $\mathrm{NaHCO}_{3}, \mathrm{NaOH}$, and $\mathrm{H}_{2} \mathrm{SO}_{4}$.

\subsection{Materials and Methods}

\subsubsection{Source and preparation of CaP granules}

$\mathrm{CaP}$ granules were produced in a $45 \mathrm{~L}$ bioreactor fed with $\mathrm{BW}$, which was collected in a Neighborhood with 32 houses in Sneek (the Netherlands). The bioreactor design was based on a combination between UASB reactor and GL reactor with a concentric tube for mixing as described in Chapter 6. The UASB-GL reactor operated 300 days with an organic loading rate (OLR) of $0.8 \pm 0.4 \mathrm{gCOD} \mathrm{L}^{-1} \mathrm{~d}^{-1}$ and hydraulic retention time (HRT) of $23.8 \pm 12.3$ days at $25^{\circ} \mathrm{C}$. The influent $\mathrm{P}$ and $\mathrm{PO}_{4}{ }^{3-}$ (soluble) loadings were $12 \pm 4 \mathrm{mgP}_{\text {Total }} \mathrm{L}^{-1} \mathrm{~d}^{-1}$ and $3 \pm 1 \mathrm{mgPO}_{4}{ }^{3-}$ $-\mathrm{P} \mathrm{L}^{-1} \mathrm{~d}^{-1}$ of which $90 \pm 4 \%$ and $88 \pm 6 \%$ were retained in the reactor during steady state, respectively. Sludge containing $\mathrm{CaP}$ granules was taken from the bottom of the reactor on operation days $167,204,258$, and 300 and stored at $4^{\circ} \mathrm{C}$ before being subjected to the preparation procedure. The preparation consisted of flotation and size separation in order to separate $\mathrm{CaP}$ granules (> $0.4 \mathrm{~mm}$ diameter) from flocculent sludge. The flotation was based 
on the ideal internal mixing in the UASB-GL reactor, which was not achieved due to the concentration of suspended solids at the bottom of the reactor and the consequent increase in sludge bed viscosity, lowering the upward drag force and shear rate. The mixing is essential to reduce the thickness of the outer biofilm, increasing the P content in CaP granules. Firstly, 60 to $80 \mathrm{ml}$ of sludge containing $\mathrm{CaP}$ granules were placed in a vertical column (Appendix D1). Then, paper filtered effluent from the UASB-GL reactor was used as mobile phase to fluidize the particles in the column at $76 \mathrm{~m} \mathrm{~h}^{-1}$ for $3 \mathrm{~min}$. Light inorganic and organic particles were washed out at the top of the column where they were collected. Then, the washout mixed suspended solids liquor (MLSS) was centrifuged at $3750 \mathrm{~g}$ for $10 \mathrm{~min}$, and the resulting pellet was dried at room temperature before further analysis. This fraction is named "organic fraction" for simplification and contain flocculent sludge and residuals from the outer biofilm around the $\mathrm{CaP}$ granules. The particles retained in the column were further subjected to a size separation using laboratory mesh sieves. Then, particles larger $0.4 \mathrm{~mm}$ diameter were thoroughly washed with the same mobile phase (effluent), dried at room temperature, and stored for further analyses. These particles are referred to as $\mathrm{CaP}$ granules. A fraction of $\mathrm{CaP}$ granules from days 167 and 258 were incinerated at $550^{\circ} \mathrm{C}$ for $2 \mathrm{~h}$ to evaluate the effect of posttreatment on $\mathrm{P}$ and heavy-metal contents.

\subsubsection{Crystallinity and morphology}

XRD analyses of the harvested $\mathrm{CaP}$ granules and organic fractions were performed through a Bruker D8 Advance diffractometer $280 \mathrm{~mm}$ measurement radius using Cu radiation with Linear PSD $3^{\circ}$ detector opening, divergence slit at $0.58^{\circ}$, and a soller slit at $2.5^{\circ}$. The degree of crystallinity was measured by Rietveld pattern fitting using the software TOPAS (Bruker). The R-weighted pattern was kept below 10 for all modeled spectra. The Lorentzian and Gaussian component convolutions of the identified phase structures of hydroxyapatite (HAP, COD 9002216 P_63/m) and calcite (COD 9016706 R_-3_c) were used for model fitting. The morphology of CaP granules and cross-section elemental mapping were obtained by a scanning electron microscope (SEM) JEOL JSM-6480LV coupled with NORAN Systems SIX EDX (Thermo Scientific, USA).

\subsubsection{Chemical analysis}

Quantitative elemental composition (P, Ca, Mg, K, Na, S, Fe, Cu, Zn, Al, Cr, Ni, Cd, $\mathrm{As}$ and $\mathrm{Pb}$ ) of $\mathrm{CaP}$ granules and organic fractions were measured with inductively coupled plasma - optical emission spectroscopy (Perkin Elmer Optima 5300 DV ICP-OES) after an $\mathrm{HNO}_{3}(69 \%)$ digestion using microwave induced heating (Milestone Ethos Easy) at $148^{\circ} \mathrm{C}$ for 
$15 \mathrm{~min}$. The volatile suspended solids (VSS) content was determined by the weight difference between the sample dried at $105^{\circ} \mathrm{C}$ for $12 \mathrm{~h}$ and the burned sample at $550{ }^{\circ} \mathrm{C}$ for $2 \mathrm{~h}$ (Clesceri et al., 1998).

Micropollutants listed in the Table D2.1 in Appendix D were analyzed with liquid chromatography - tandem mass spectrometry (LC-MS/MS) after a solid/liquid extraction using $100 \mathrm{mg}$ of solid sample and $2 \mathrm{ml}$ of solvent solution. The solvent solution contained $5 \mathrm{M}$ methanol, $200 \mathrm{mM}$ formic acid, $15 \mathrm{mM}$ ammonia, and $1 \mathrm{mM}$ oxalic acid. The extraction mixture was vigorously shaken for $60 \mathrm{~min}$ and then centrifuged at $3750 \mathrm{~g}$ for $15 \mathrm{~min}$. The supernatant was divided $(2 \times 450 \mu \mathrm{l})$ into 2 vials/sample. In one vial a standard solution containing all the analyzed compounds (Table D2.2 in Appendix D) was added to verify the measurements during the analytical process. In both vials, an internal standard (Table D2.3 in Appendix D) was added. Then, the micropollutants were analyzed in an Agilent LC-MS/MS system consisting of Agilent infinity 1260 LC-system (degasser, binary pump, auto sampler with cooled tray and column oven) and Agilent 6420 triple Quadrupole Mass Spectrometer with Electrospray ion source. The compounds were separated by an Agilent Zorbax RRHD Eclipse Plus C18 (50 x $2 \mathrm{~mm}$, particle size $1.8 \mu \mathrm{m})$ and a gradient of acetonitrile and ammonium formate in water. The detection and quantification occurred on the 6420-QQQ-MS using compound specific multiple Dynamic MRM transitions using three methods (positive neutral, acidic, and negative). The quantification was based on the external standard solution containing all the micropollutants.

\subsubsection{Bioavailability}

$\mathrm{PO}_{4}{ }^{3-}$ dissolution test with $2 \%$ citric acid was adapted from the standard method 4.1.6.1 of the method book II of the Association of German Agricultural Research Institutes (VDLUFA, 1995). Before the dissolution tests, all the samples were thoroughly ground with a mortar and pestle. The variation in surface area after grinding was neglected. The experiments were conducted for $30 \mathrm{~min}$ in $50 \mathrm{ml}$ volumetric flasks continuously shaken at 100 rpm. For each test $0.5 \mathrm{~g}$ of ground sample was dispersed in $2 \%$ citric acid solution, which was prepared using citric acid monohydrate (Sigma Aldrich), and in distilled water as a reference control. After $30 \mathrm{~min}$, the mixed solution was filtered with $0.45 \mu \mathrm{m}$ glass fiber filters (Cronus PTFE filter) and immediately prepared for further analysis with ion chromatography (Metrohm 761 Compact) for cations $\left(\mathrm{Ca}^{2+}, \mathrm{NH}_{4}{ }^{+}\right.$and $\left.\mathrm{Mg}^{2+}\right)$ and anions $\left(\mathrm{PO}_{4}{ }^{3-}\right)$ and with ICP-OES for elements ( $\mathrm{P}, \mathrm{Ca}, \mathrm{Mg}, \mathrm{Fe}$, and $\mathrm{Al})$. The experiments were tested for all aforementioned samples of $\mathrm{CaP}$ granules, as well as commercial hydroxyapatite (Sigma Aldrich) and struvite produced by mixing $\mathrm{MgO}$ and urine. 


\subsubsection{Sequential extraction}

$\mathrm{PO}_{4}{ }^{3-}$ was extracted from $0.5 \mathrm{~g}$ of ground $\mathrm{CaP}$ granules using a sequence of three solutions, containing $0.5 \mathrm{M}$ of $\mathrm{NaHCO}_{3}, 0.1 \mathrm{M} \mathrm{NaOH}$, and $1 \mathrm{M} \mathrm{H}_{2} \mathrm{SO}_{4}$, to measure $\mathrm{P}$ bound to organics, to $\mathrm{Al}$ or $\mathrm{Fe}$, and to other inorganic material, respectively. Ground $\mathrm{CaP}$ granules are firstly placed in a $50 \mathrm{ml}$ falcon tube containing $30 \mathrm{ml}$ of $\mathrm{NaHCO}_{3}$ solution for $16 \mathrm{~h}$ at 100 rpm. Then, the mixture is centrifuged at $3750 \mathrm{~g}$ for $10 \mathrm{~min}$. Fine suspended solids in the supernatant after centrifugation are collected by paper filtration with a pore size of $3 \mu \mathrm{m}$ (Whatmann blue ribbon filters). The solids retained on the filter were mixed with the pellet of the centrifugation by rinsing with the next solution $(\mathrm{NaOH})$ to a final mixture volume of 30 $\mathrm{ml}$. The new mixture is mixed for $16 \mathrm{~h}$ at $100 \mathrm{rpm}$ for $\mathrm{PO}_{4}{ }^{3-}$ extraction and afterward centrifuged as mentioned before. The supernatant is paper filtered as in the previous step, but the solids on the filter were mixed with the pellet using $\mathrm{H}_{2} \mathrm{SO}_{4}$ solution to a final volume of 30 $\mathrm{ml}$. The mixture is once more mixed for $\mathrm{PO}_{4}{ }^{3-}$ extraction and centrifuged, and the supernatant is paper filtered. $\mathrm{PO}_{4}{ }^{3-}$ (soluble) and total $\mathrm{P}$ was determined in the paper filtrated supernatant after each extraction step using IC and ICP-OES, respectively. The mass balance was calculated considering the percentage of $\mathrm{P}$ in $\mathrm{CaP}$ granules dissolved during each extraction.

\subsection{Results}

\subsection{1. $\mathrm{Ca}_{\mathbf{x}}\left(\mathrm{PO}_{4}\right)_{\mathrm{y}}$ content and crystallinity}

The separation procedure (flotation at $76 \mathrm{~m} \mathrm{~h}^{-1}$ plus size fractionation) after harvesting the $\mathrm{CaP}$ granules increased the $\mathrm{P}$ content in the granules from $7.8 \pm 0.6 \mathrm{wt} \%$ in raw $\mathrm{CaP}$ granules to $10.1 \pm 0.8 \mathrm{wt} \%$ after post-separation (Figure 7.1a). The $\mathrm{P}$ in the separated fraction of $\mathrm{CaP}$ granules represented $75 \pm 4 \%$ of the total $\mathrm{P}$ in the sludge taken from the bottom of the reactor. The remaining $25 \pm 1 \%$ of $\mathrm{P}$ was in the residual sludge (organic fraction). The average content of $\mathrm{P}$ in $\mathrm{CaP}$ granules harvested at different operational times corresponded to $23 \pm 2 \mathrm{wt} \% \mathrm{P}_{2} \mathrm{O}_{5}$. The $\mathrm{P}$ content in $\mathrm{CaP}$ granules decreases slightly over time (from $10.6 \pm 0.1$ wt $\%$ on day 167 to $9.1 \pm 0.3 \mathrm{wt} \%$ on day 300 ) with a $\mathrm{Ca} / \mathrm{P}$ molar ratio of $1.9 \pm 0.3$ (the $\mathrm{Ca} / \mathrm{P}$ molar ratio of HAP $\left(\mathrm{Ca}_{10}\left(\mathrm{PO}_{4}\right)_{6} \mathrm{OH}_{2}\right)$ is 1.67). The calculated co-precipitation of $\mathrm{Ca}$ with $\mathrm{CaCO}_{3}$ and organic compounds represented on average $14 \pm 3 \%$ of the $\mathrm{Ca}$ in $\mathrm{CaP}$ granules. $\mathrm{Mg}, \mathrm{S}, \mathrm{K}$, and $\mathrm{Na}$ concentrations in $\mathrm{CaP}$ granules were $0.35 \pm 0.06,0.29 \pm 0.03,0.11 \pm 0.02$, and $0.28 \pm 0.03 \mathrm{wt} \%$, respectively. The VSS content in CaP granules was on average $29 \pm 2$ wt\% (Figure 7.1a). According to Rietveld pattern fitting, the degree of crystallinity in CaP granules was $77 \pm 2 \%$, from which $67 \pm 6 \%$ and $11 \pm 6 \%$ was HAP and calcite, respectively (Figure 7.1b). The estimated average content of amorphous composites in CaP granules was 
$22 \pm 1 \%$. Further to the CaP granules, an organic fraction was present as more flocculent matter. This organic fraction sampled on operation days $167,204,258$, and 300 contained a $P$ and VSS content of $4.0 \pm 1.1$ and $71 \pm 2 \mathrm{wt} \%$, respectively.

Peak identification showed that HAP and calcite were the dominant crystal phases in CaP granules (Figure 7.1 from 1 to 4). Moreover, SEM-EDX analysis showed that $\mathrm{P}, \mathrm{Ca}$, and $\mathrm{O}$ were the most abundant elements in $\mathrm{CaP}$ granules (Figure 7.1c) and the $\mathrm{Ca}_{\mathrm{x}}\left(\mathrm{PO}_{4}\right)_{\mathrm{y}}$ enrichment in $\mathrm{CaP}$ granules is occurring via agglomeration of crystal units (Figure 7.1d). This growth mechanism of calcium phosphate granules is consistent with the one described in Cunha et al. (2018b).
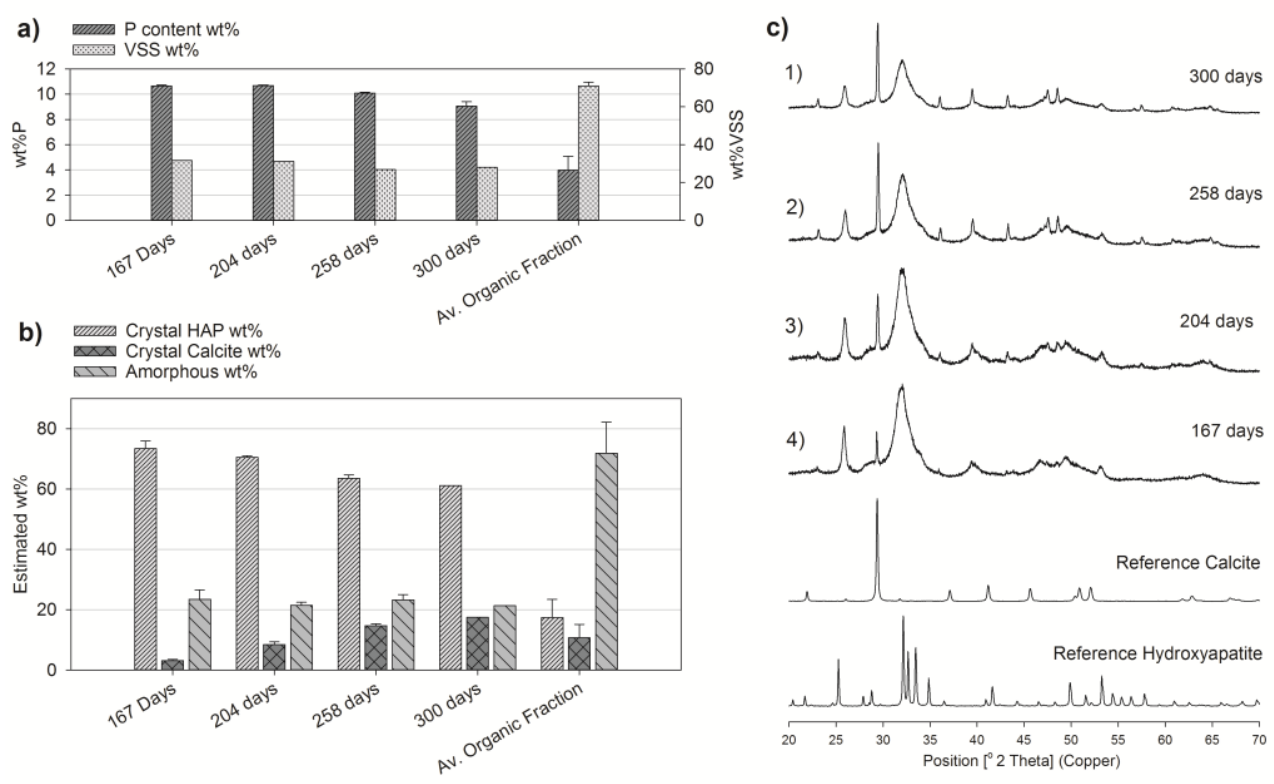

Figure 7.1 P and VSS contents of CaP granules taken at on operation days 167, 204, 258, and 300 and non-granule fraction (averaged organic fractions) (a). Estimated mass percentage of crystal hydroxyapatite and calcite and amorphous composites, based on Rietveld pattern fitting for the same samples (b). XRD spectrum of the four $\mathrm{CaP}$ granules samples and of hydroxyapatite and calcite references (c). 

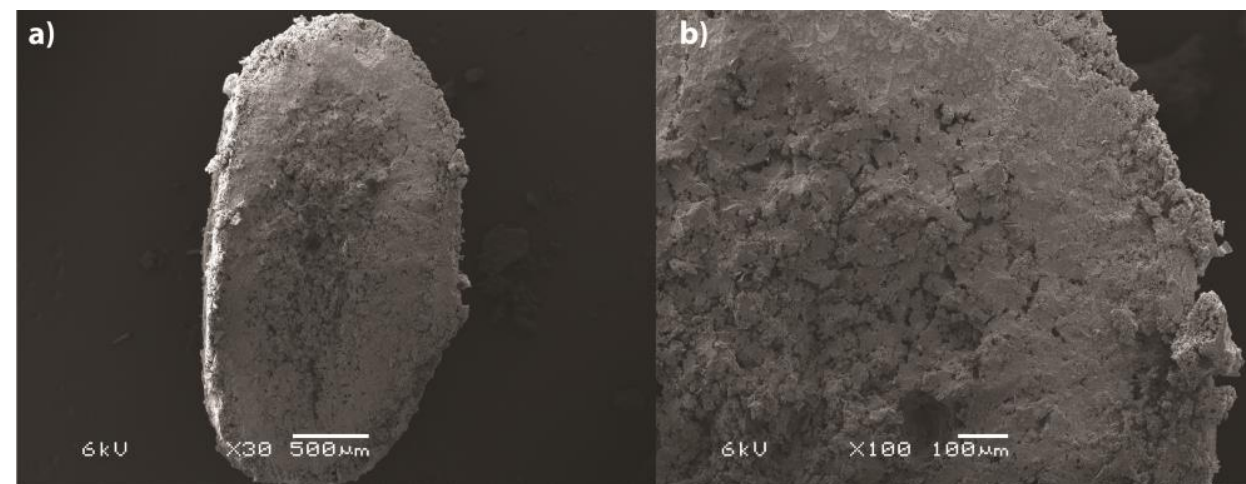

c)

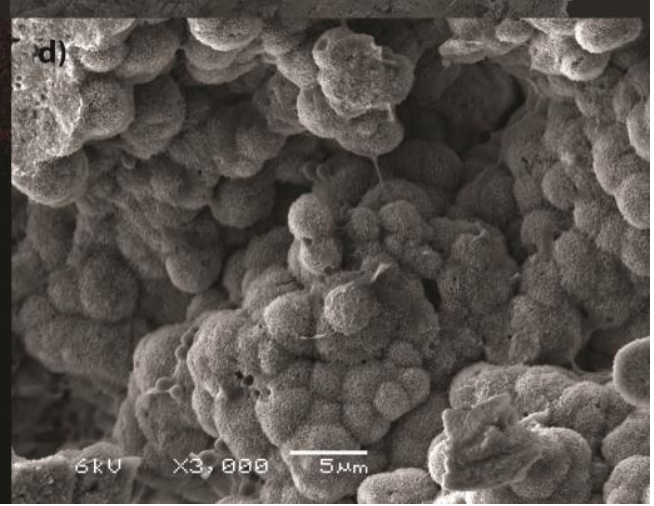

Figure 7.2 SEM illustration of the cross-section of a representative $\mathrm{CaP}$ granule at different magnifications (a, b, and d) and EDX elemental mapping of the granule cross-section (c). Note that the greenish colour result from the simultaneous presence of $\mathrm{Ca}$ and $\mathrm{P}$.

\subsubsection{Heavy metals}

The metal present at the highest concentration in CaP granules was $\mathrm{Fe}(1099 \mathrm{mg} \mathrm{kg}$ ${ }^{1}$ total solids (TS)) followed by $\mathrm{Al}$ (304 mg kg-1 TS), $\mathrm{Zn}$ (183 $\left.\mathrm{mg} \mathrm{kg}^{-1} \mathrm{TS}\right)$, and $\mathrm{Cu}$ (47 $\mathrm{mg} \mathrm{kg}^{-}$ $\left.{ }^{1} \mathrm{TS}\right)$. All the other metals $(\mathrm{Cr}, \mathrm{Ni}, \mathrm{Cd}, \mathrm{As}$, and $\mathrm{Pb}$ ) were below $\mathrm{Cu}$ (Table 7.1). Moreover, the concentration of heavy metals $(\mathrm{Cu}, \mathrm{Zn}, \mathrm{Cr}, \mathrm{Ni}, \mathrm{Cd}, \mathrm{As}$, and $\mathrm{Pb})$ in $\mathrm{CaP}$ granules was below the regulatory limits for application as inorganic and organic fertilizer within the Netherlands and Europe (Table 7.1). For instance, $\mathrm{Cd}$ and $\mathrm{Ni}$, which often limit the application of SSA and phosphate rock, were 8 and 4 times lower in $\mathrm{CaP}$ granules than the European regulatory limit (Table 7.1 and Table 7.2). Furthermore, the overall heavy metal content in $\mathrm{CaP}$ granules was lower than in the separate organic fraction, consisting of dispersed sludge and the remains of the detached biofilm from CaP granules (Table 7.1); the values were obtained by the averaged concentration of heavy metals for $\mathrm{CaP}$ granules and the respective organic fractions taken at different operation days as aforementioned. The separate organic fraction from $\mathrm{CaP}$ granules could not be used as fertilizer in the Netherlands, because of the relatively high $\mathrm{Zn}$ content 
(Table 7.1), but at European level, it complies with the regulation for application as organic fertilizer, regarding heavy metals (European Commission, 2016).

The organic content in CaP granules ( $29 \mathrm{wt} \%$ ) limits the direct replacement of phosphate rock in the fertilizer industry. In the thermal route, the organics reduce the particle strength during the sintering of milled solids containing $\mathrm{P}$, decreasing the downstream production capacity, and in the wet route, the organics release unwanted fumes (Abouzeid, 2008; Schipper et al., 2001). Therefore, the characteristics of glowed CaP granules were assessed and compared with other products used as inorganic fertilizer and as raw material for P fertilizer production (Table 7.2). All the regulated heavy metal concentrations were below the limits for application of glowed $\mathrm{CaP}$ granules as inorganic fertilizer. Moreover, the heavy metal content in glowed $\mathrm{CaP}$ granules was similar or lower than phosphate rock and triple superphosphate (TSP). Additionally, glowed CaP granules, which are free of organic compounds, complied with the requirements as a raw material for the fertilizer industry, including the $\mathrm{P}$ content which was on average $34 \mathrm{wt} \% \mathrm{P}_{2} \mathrm{O}_{5}$. 
Table 7.1 Heavy-metals assessment ( $\mathrm{mg} \mathrm{kg}^{-1}$ total solids (TS)) for CaP granules and organic fraction and lower regulatory limits for application as both inorganic and organic fertilizer in the Netherlands (NL) and Europe (EU), according to the revised fertilizer regulation, and for application of sewage sludge in Europe (EU) and the criteria for Eco-Label based on JRC/IPTS (2011).

\begin{tabular}{|c|c|c|c|c|c|c|c|c|c|}
\hline & $\begin{array}{c}\mathrm{CaP} \\
\text { Granules } \\
\mathrm{N}=8\end{array}$ & & $\begin{array}{c}\text { Organic } \\
\text { Fraction } \\
\mathrm{N}=8\end{array}$ & & $\begin{array}{c}f \\
\frac{[\text { Organic fraction }]}{[\text { CaP granules }]}\end{array}$ & $\begin{array}{c}\text { Fertilizer } \\
\qquad(\mathrm{NL}) \\
{[1]}\end{array}$ & $\begin{array}{c}\text { Fertilizer } \\
\text { (EU) } \\
{[2]}\end{array}$ & $\begin{array}{c}\text { Sewage } \\
\text { Sludge } \\
\text { (EU86/278) } \\
{[3]}\end{array}$ & $\begin{array}{c}\text { Eco-label } \\
\text { Fertilize } \\
{[4]}\end{array}$ \\
\hline $\mathrm{mg} \mathrm{kg}^{-1} \mathrm{TS}$ & & $s d$ & & $s d$ & $\frac{\mathrm{mg} \mathrm{kg}_{\mathrm{TS}}^{-1}}{\mathrm{mg} \mathrm{kg}_{\mathrm{TS}}^{-1}}$ & & & & \\
\hline $\mathrm{Fe}$ & 1099 & 175 & 1648 & 356 & 1.5 & n.a & n.a & n.a & n.a \\
\hline $\mathrm{Cu}$ & 47 & 5 & 214 & 14 & 4.5 & 75 & n.a. & $1000-1750$ & 100 \\
\hline $\mathrm{Zn}$ & 183 & 31 & 780 & 59 & 4.3 & 300 & n.a. & $2500-4000$ & 400 \\
\hline $\mathrm{Al}$ & 304 & 60 & 868 & 138 & 2.9 & n.a & n.a. & n.a & n.a \\
\hline $\mathrm{Cr}$ & 39 & 6 & 59 & 24 & 1.5 & 75 & $2(\mathrm{Cr} \mathrm{VI})$ & n.a & 100 \\
\hline $\mathrm{Ni}$ & 13 & 3 & 24 & 2 & 1.9 & 30 & 50 & $300-400$ & 50 \\
\hline $\mathrm{Cd}$ & 0.18 & 0.02 & 0.70 & 0.04 & 3.5 & 1.25 & 1.5 & $20-40$ & 1.5 \\
\hline As & 0.20 & 0.00 & 0.63 & 0.05 & 3.1 & 15 & 60 & n.a & n.a \\
\hline $\mathrm{Pb}$ & 1.18 & 0.28 & 4.75 & 0.42 & 3.6 & 100 & 120 & $750-1200$ & 120 \\
\hline
\end{tabular}

[1] Ehlert et al. (2013); [2] European Commission (2016); [3] European Commission (1986); [4] Quintero et al. (2015) n.a.: not applicable 
Table 7.2 Comparison of $\mathrm{P}$ and heavy-metal contents in $\mathrm{CaP}$ granules after glowing at $550^{\circ} \mathrm{C}$ for $2 \mathrm{~h}$ with other recovered products, phosphate rock, triple superphosphate, and the requirements for fertilizer industry.

\begin{tabular}{|c|c|c|c|c|c|c|c|c|}
\hline & & $\begin{array}{c}\mathrm{CaP} \\
\text { Granules } \\
\left(550^{\circ} \mathrm{C}\right) \\
\text { (this study) }\end{array}$ & $s d$ & $\begin{array}{c}\text { Struvite } \\
\text { (Urine) [1] }\end{array}$ & Sewage Sludge Ash [2] & $\begin{array}{c}\text { Phosphate } \\
\text { Rock } \\
{[3]}\end{array}$ & $\begin{array}{c}\text { Triple } \\
\text { Superphosphate } \\
\text { (TSP) } \\
\text { [3] }\end{array}$ & $\begin{array}{c}\text { Requirements } \\
\text { for Fertilizer } \\
\text { Industry } \\
{[4]}\end{array}$ \\
\hline $\mathrm{P}$ & $\mathrm{wt} \%$ & 15 & 1 & 12 & 9 & 13 & 20 & $>11$ \\
\hline $\mathrm{P}_{2} \mathrm{O}_{5}$ & $\mathrm{wt} \%$ & 34 & 2 & 27 & 21 & 30 & 45 & $>25$ \\
\hline $\mathrm{Fe}$ & $\mathrm{mg} \mathrm{kg}^{-1} \mathrm{TS}$ & 1577 & 390 & 480 & 58500 & 2253 & 2160 & $<10000$ \\
\hline $\mathrm{Cu}$ & & 73 & 10 & 90 & 767 & 31 & 22 & $<500$ \\
\hline $\mathrm{Zn}$ & & 274 & 69 & 225 & 2330 & 426 & 390 & $<1000$ \\
\hline $\mathrm{Al}$ & & 443 & 100 & n.a. & 67200 & 2642 & 2818 & n.a. \\
\hline $\mathrm{Cr}$ & & 57 & 11 & $<2$ & 159 & 148 & 171 & n.a. \\
\hline $\mathrm{Ni}$ & & 16 & 2 & 2 & 73 & 41 & 27 & n.a. \\
\hline $\mathrm{Cd}$ & & 0.23 & 0.02 & $<2$ & 2 & 23 & 24 & n.a. \\
\hline As & & 0.25 & 0.07 & $<11$ & 11 & 14 & 8 & n.a. \\
\hline $\mathrm{Pb}$ & & 1.65 & 0.07 & $<22$ & 123 & 4 & 4 & n.a. \\
\hline $\mathrm{Sr}$ & & n.d & & n.a. & n.a. & 1057 & 909 & n.a. \\
\hline $\mathrm{U}$ & & n.d & & n.a. & n.a. & 141 & 125 & n.a. \\
\hline
\end{tabular}

n.d. - not determined; n.a. - not available / not applicable; [1] Gell et al. (2011); [2] Herzel et al. (2016); [3] Kratz et al. (2016); [4] Schipper et al. (2001) 


\subsubsection{Organic micropollutants}

Pharmaceuticals and personal care and household products were detected in both the $\mathrm{CaP}$ granules and the respective separated organic fractions (Table 7.3). In the granules, Cetirizine, which is an antihistamine for treatment of allergies, was found at the highest concentration of $2.5 \mathrm{mg} \mathrm{kg}^{-1} \mathrm{Ts}$, followed by Doxycycline, Ciprofloxacin, Oxazepam, and Azithromycin which were found in the range of 0.2 to $0.5 \mathrm{mg} \mathrm{kg}^{-1} \mathrm{Ts}$. Azithromycin, Ciprofloxacin, and Doxycycline were the antibiotics found at the highest concentrations in $\mathrm{CaP}$ granules and organic fractions. Azithromycin was on average 4 times more concentrated in the organic fraction $\left(0.9 \mathrm{mg} \mathrm{kg}{ }^{-1} \mathrm{TS}\right)$ than in $\mathrm{CaP}$ granules $\left(0.2 \mathrm{mg} \mathrm{kg}^{-1} \mathrm{TS}\right)$. Carbamazepine and Gabapentin (both antiepileptics) were also found in $\mathrm{CaP}$ granules and the respective organic fractions. Ibuprofen, which is a common anti-inflammatory, was only measurable in one sample of $\mathrm{CaP}$ granules ( $\left.56 \mu \mathrm{g} \mathrm{kg}^{-1} \mathrm{TS}\right)$, while it was found to be more concentrated in the organic fraction $\left(131 \mu \mathrm{g} \mathrm{kg}^{-1} \mathrm{TS}\right)$. Diclofenac, which is another anti-inflammatory, was less concentrated and evenly distributed between the $\mathrm{CaP}$ granules and the organic fraction ( 7 to 8 $\mu \mathrm{g} \mathrm{kg}^{-1} \mathrm{TS}$ ). Other compounds were measured, but were below the detection limit (Table D2.4 in Appendix D). Reported concentration ranges for measured micropollutants in BW, SS, and animal manure are also given in Table 7.3. Ciprofloxacin, Oxytetracyclin, and Tetracycline were detected at relatively high levels in SS and animal manure, when compared with the CaP granules. 
Table 7.3 Average concentration of micropollutants in CaP granules and separate organic fractions $\left(\mu \mathrm{g} \mathrm{kg}^{-1}\right.$ total solids (TS) and $\mu \mathrm{g} \mathrm{kg}{ }^{-1} \mathrm{volatile}$ solids (VS)) for all samples taken. $\mathrm{N}$ refers to the number of samples where each specie was detected. The complete list of analyzed compounds and recoveries are in Table D2.4 and D2.5 of Appendix D. Reference concentration ranges of measured compounds for black water (BW) and sewage sludge (SS) and animal manure.

\begin{tabular}{|c|c|c|c|c|c|c|c|c|c|c|c|c|c|c|}
\hline Description & Type & $\mathrm{N}$ & 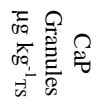 & $s d$ & 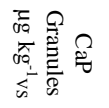 & $s d$ & $\mathrm{~N}$ & 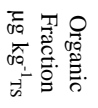 & $s d$ & 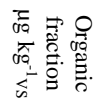 & $s d$ & 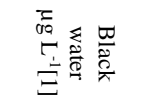 & 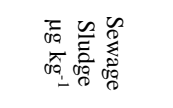 & 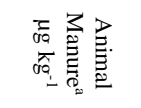 \\
\hline Cetirizine & Antihistamine & 5 & 2502 & 241 & 8379 & 489 & 5 & 4186 & 181 & 5968 & 408 & & & \\
\hline Doxycycline & Antibiotic & 5 & 460 & 28 & 1547 & 148 & 5 & 377 & 53 & $\mathbf{5 3 7}$ & 78 & & $966-1780^{[5]}$ & $550-3100^{[6] \mathrm{b}}$ \\
\hline Ciprofloxacin & Antibiotic & 5 & 353 & 157 & 1157 & 450 & 5 & 374 & 153 & $\mathbf{5 3 7}$ & 232 & $0-500$ & $1600-11000^{[4,5]}$ & $300-3000^{[7]}$ \\
\hline Oxazepam & Sedative & 5 & 219 & 31 & 737 & 115 & 5 & 549 & 49 & 781 & 70 & $3-45$ & & \\
\hline Azithromycin & Antibiotic & 5 & 198 & 119 & 665 & 380 & 5 & 932 & 330 & 1324 & 461 & & $50-1220^{[2,5]}$ & \\
\hline Metformin & Antidiabetic & 5 & 63 & 20 & 214 & 83 & 5 & 70 & 19 & 100 & 29 & $3000-8000$ & $300-450^{[5]}$ & \\
\hline Ibuprofen & Anti-inflammatory & 1 & 56 & - & 178 & - & 5 & 131 & 59 & 185 & 81 & $25-125$ & $10-600^{[2,3]}$ & \\
\hline Benzalkonium Chloride $\mathrm{C} 12$ & Biocide & 5 & 44 & 14 & 144 & 37 & 5 & 161 & 35 & 229 & 53 & 16 & n.d. $-120^{[4]}$ & \\
\hline Metoprolol & B-blocker & 5 & 39 & 6 & 133 & 27 & 5 & 142 & 26 & 201 & 32 & $200-550$ & $130-170^{[3]}$ & \\
\hline Tetracycline & Antibiotic & 5 & 28 & 27 & 90 & 89 & 5 & 12 & 5 & 17 & 8 & & $<8-2790^{[3,5]}$ & n.d. $-1600^{[6,7]}$ \\
\hline Paracetamol & Analgesic & 4 & 24 & 11 & 81 & 34 & 5 & 16 & 6 & 22 & 8 & $2000-10000$ & & \\
\hline Caffeine & Stimulant & 5 & 13.2 & 6.0 & 43.7 & 18.8 & 5 & 19.1 & 13.0 & 27.6 & 19.3 & & $55-1600^{[3]}$ & \\
\hline Diclofenac & Anti-inflammatory & 5 & 7.6 & 3.2 & 25.8 & 12.1 & 5 & 6.9 & 1.7 & 9.9 & 2.5 & $0-15$ & $100-350^{[2,3]}$ & \\
\hline Benzalkonium Chloride C14 & Biocide & 4 & 4.8 & 2.0 & 15.4 & 5.9 & 5 & 16.0 & 2.9 & 22.8 & 4.4 & & n.d. $-120^{[4]}$ & \\
\hline Carbamazepine & Antiepileptic & 5 & 4.2 & 2.8 & 13.7 & 8.6 & 5 & 7.5 & 5.7 & 10.8 & 8.4 & & $8-550^{[2,3]}$ & \\
\hline Ofloxacin & Antibiotic & 5 & 3.2 & 2.1 & 10.3 & 6.5 & 4 & 1.5 & 0.6 & 2.2 & 0.8 & & n.d. $-200^{[2]}$ & \\
\hline Gabapentine & Antiepileptic & 5 & 2.4 & 1.5 & 8.0 & 5.0 & 5 & 1.6 & 1.1 & 2.3 & 1.6 & & & \\
\hline Oxytetracyclin & Antibiotic & 5 & 1.6 & 0.4 & 5.5 & 1.4 & 2 & 2.0 & 0.1 & 2.8 & 0.3 & & $60-114^{[5]}$ & $\begin{array}{c}9700- \\
170000^{[7]}\end{array}$ \\
\hline Sulfapyridine & Antibiotic & 1 & 1.3 & - & 4.3 & - & 5 & 2.3 & 0.9 & 3.3 & 1.3 & & & \\
\hline Clindamycin & Antibiotic & 2 & 0.7 & 0.06 & 2.1 & 0.2 & 2 & 0.6 & 0.1 & 0.9 & 0.1 & & & \\
\hline Hydrochlorothiazide & Antidiabetic & 5 & $<5$ & - & - & - & 5 & 88.7 & 17.8 & 125.9 & 21.7 & $100-600$ & n.d. $-390^{[2,3]}$ & \\
\hline Clarithromycin & Antibiotic & 2 & 0.23 & 0.04 & 0.7 & 0.1 & 2 & 0.61 & 0.5 & 0.9 & 0.7 & & n.d. $-350^{[4,5]}$ & \\
\hline
\end{tabular}

2008); ${ }^{\mathrm{a}}$ - reference for swine and chicken manure; ${ }^{\mathrm{b}}$ - for Doxytetracycline; n.d. - not detected. 


\subsubsection{Bioavailability}

In $2 \%$ citric acid solution, $35 \pm 5 \%$ of the $\mathrm{P}$ in $\mathrm{CaP}$ granules dissolved within $30 \mathrm{~min}$ (Figure 7.3), which is similar as struvite produced from urine $(33 \pm 3 \%)$ and higher than powder HAP (14\%) under the same conditions. In distilled water, the P dissolution was below $2 \%$ for $\mathrm{CaP}$ granules, struvite, and HAP. The sequential extraction showed that most $\mathrm{P}(85 \pm$ $2 \%$ ) was dissolved in acidic conditions $\left(\mathrm{H}_{2} \mathrm{SO}_{4}\right)$, while only $0.1 \%$ and $6 \%$ was dissolved in strong-alkaline $(\mathrm{NaOH})$ and weak-alkaline $\left(\mathrm{NaHCO}_{3}\right)$ conditions, respectively.
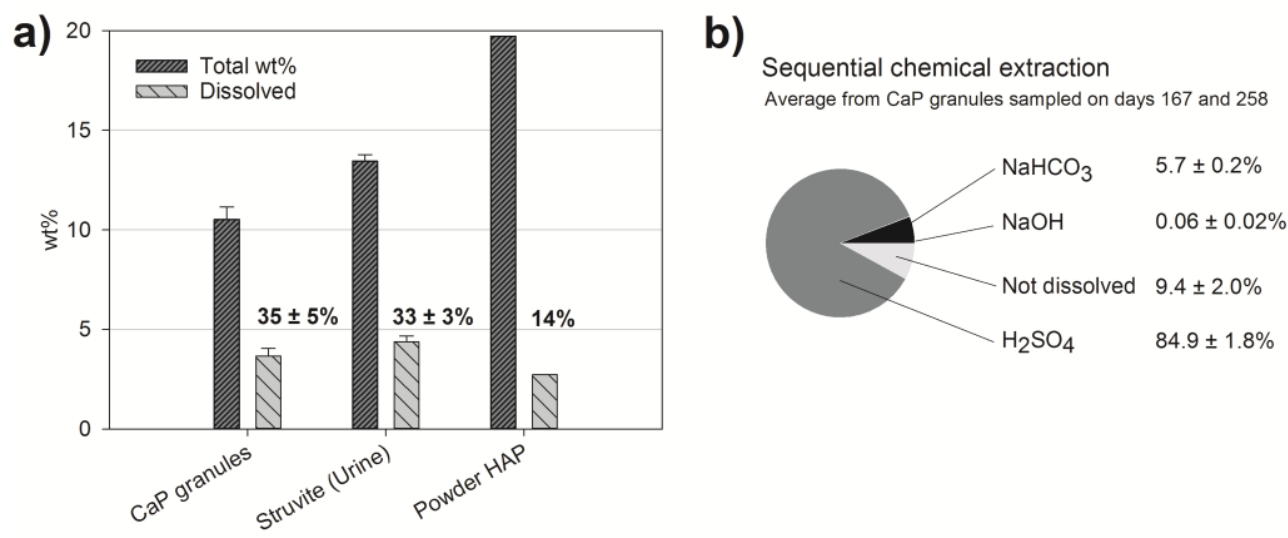

Figure 7.3 Dissolution test for $\mathrm{PO}_{4}{ }^{3-}$ in ground $\mathrm{CaP}$ granules (average from CaP granules taken on operation days 167, 204, 258, and 300), ground struvite produced from urine, and powder hydroxyapatite (HAP), using $2 \%$ citric acid solution according to the standard method VDLUFA (1995) (a). Sequential chemical extraction of $\mathrm{PO}_{4}{ }^{3-}$ from CaP granules taken on operation days 167 and 258, using $\mathrm{NaHCO}_{3}$ for organically bound $\mathrm{P}, \mathrm{NaOH}$ for $\mathrm{Al}$ and $\mathrm{Fe}$ bound $\mathrm{P}$, and $\mathrm{H}_{2} \mathrm{SO}_{4}$ for dissolution of other inorganic $\mathrm{P}(\mathrm{b})$.

\subsection{Discussion}

\subsubsection{Compositional and crystallographic characteristics of CaP granules}

The concentration of macro elements in $\mathrm{CaP}$ granules was relatively stable, although a large variation in the influent $\left(\mathrm{BW}\right.$ ) concentrations of organic matter (from 3 to $42 \mathrm{gCOD}_{\text {Total }}$ $\mathrm{L}^{-1}$ ), bicarbonate (from 0.8 to $3.6 \mathrm{gHCO}_{3}{ }^{-} \mathrm{L}^{-1}$ ), and nutrients (from 94 to $480 \mathrm{mgP}_{\text {Total }} \mathrm{L}^{-1}, 76$ to $558 \mathrm{mgCa}_{\text {Total }} \mathrm{L}^{-1}$ and 21 to $201 \mathrm{mgMg}_{\text {Total }} \mathrm{L}^{-1}$ ) was observed during the operation of the gas-lift mixed UASB reactor as described in Chapter 6. The average $\mathrm{P}$ content in $\mathrm{CaP}$ granules taken on operation days 167, 204, 258, and 300 showed a decrease of 14\% (Figure 7.1), due to an increase in bulk pH from 7.4 on operation day 220 to 7.7 on day 300 , caused by an increase in $\mathrm{HCO}_{3}{ }^{-}$, and consequently, more $\mathrm{CaCO}_{3}$ precipitation (Chapter 6). The robustness 
of the process regarding compositional standardization of $\mathrm{P}$ content in the $\mathrm{CaP}$ granules is dependent on bulk pH (Chapter 5; Cunha et al., 2018b).

According to XRD analyses, HAP was the dominant crystal phase in CaP granules, with an average of $67 \mathrm{wt} \%$. However, the calculated content of HAP based on the P content in $\mathrm{CaP}$ granules is $55 \pm 4 \mathrm{wt} \%$, which is significantly lower than the percentage obtained by Rietveld pattern fitting (XRD). The difference can be explained by the nanocrystalline properties of the crystal HAP in CaP granules (Gajjeraman et al., 2007). The HAP nanocrystals in $\mathrm{CaP}$ granules widen the expected peaks located between positions $30^{\circ}$ and $35^{\circ}$ in the XRD spectrum (Figure 7.1 from 1 to 4 and the reference spectrum of HAP), overestimating the content of HAP in the modelled spectrum by $12 \%$. A much lower deviation is observed for $\mathrm{CaCO}_{3}$ (from the modelled $11 \mathrm{wt} \%$ to the calculated $14 \mathrm{wt} \%$ ). Nevertheless, the low content $(<0.5 \mathrm{wt} \%)$ of $\mathrm{Mg}, \mathrm{K}, \mathrm{Al}$, and $\mathrm{Fe}$ points to almost no $\mathrm{Mg} / \mathrm{K}$ - struvite and aluminum and iron phosphates being present. This is further supported by the chemical sequential extraction (Figure 7.3), which shows that only 6\% of the $\mathrm{P}$ in $\mathrm{CaP}$ granules is organically bound and $0.1 \%$ is connected to $\mathrm{Fe}$ or $\mathrm{Al}$. Part of the organics in $\mathrm{CaP}$ granules originates from extracellular biopolymers (Chapter 5). Latter is known to significantly contribute to particle aggregation (El-Mamouni et al., 1998; Schmidt and Ahring, 1994), which is a key step in the production of larger CaP granules. The SEM analysis of a granule cross-section (Figure 7.2) suggests that the growth of $\mathrm{CaP}$ granules is occurring via agglomeration of spherical units ( $2 \mu \mathrm{m}$ diameter), which are likely composed of HAP nanocrystals ( $\sim \mathrm{nm}$ diameter) according to existing literature (Gajjeraman et al., 2007; Tao et al., 2007). Hypothetically, the HAP nanocrystals are involved in a hydration layer containing both $\mathrm{Ca}_{\mathrm{x}}\left(\mathrm{PO}_{4}\right)_{\mathrm{y}}$ and $\mathrm{CaCO}_{3}$ amorphous phases (Bian et al., 2012; Rokidi et al., 2011). The agglomeration of crystal units is then mediated by surface to surface contact between crystal units or by contact with EPS in the granule core. With the maturation, the compactness, particle density, and settling velocity of the $\mathrm{CaP}$ granules increase, leading to the concentration of mature granules at the bottom of the reactor, where they can be harvested.

\subsubsection{Hazardous compounds in CaP granules}

The application of nutrients recovered from wastewater is often prohibited due to the presence of heavy metals, micropollutants, and pathogens. Regarding heavy metals, the separated organic fraction contained overall a higher concentration than the $\mathrm{CaP}$ granules, due to adsorption onto organic compounds, such as humic substances and solid organic matter (Amir et al., 2005; Dong et al., 2013; Kobielska et al., 2018). As shown in Table 7.1, Cu and 
$\mathrm{Zn}$ had the highest affinity for the organic fraction ( $f$ of 4.5 and 4.3 , respectively), which is in line with the findings of Amir et al. (2005) and Dong et al. (2013). The lower affinity observed for $\mathrm{Cr}$ and $\mathrm{Ni}$ is explained by association with $\mathrm{Fe}$, which had similar selectivity to the organic fraction as $\mathrm{Cr}$ and $\mathrm{Ni}$ (Dong et al., 2013). Because $29 \%$ of the $\mathrm{CaP}$ granules weight was organic (Figure 7.1), the heavy metal content in $\mathrm{CaP}$ granules might still be associated with the organic matter. Glowing of $\mathrm{CaP}$ granules reduces the organic content, but the heavy metals remain in the ash as indicated by the higher concentration of heavy metals in glowed $\mathrm{CaP}$ granules then in the raw granules (Table 7.1 and Table 7.2). Thus, the shear force applied on CaP granules by the internal mixing in the UASB-GL reactor is essential to reduce the heavy metal content in $\mathrm{CaP}$ granules by leaching of organics (outer biofilm). $\mathrm{Cd}$ and As were at very low levels for both the $\mathrm{CaP}$ granules and the organic fraction when compared to phosphate rock. $\mathrm{Pb}$ was higher than Cd and As, but still far below the regulatory limit of 100 to $120 \mathrm{mg} \mathrm{kg}^{-1} \mathrm{TS}$.

The micropollutants in $\mathrm{CaP}$ granules originate directly from human excretion and/or disposal of unused medicines, disinfectants, and cleaning products into the toilet. Thus, the variety and concentration of micropollutants are dependent on anthropological aspects at the collection of BW. The concentration of certain organic micropollutants in the organic fraction (Table 7.3) were in line with previous quantification of micropollutants in BW sludge from Butkovskyi et al. (2017). The anaerobic treatment can partially remove certain micropollutants, such as Naproxen, Paracetamol, and Sulfamethoxazole, but the combination of treatments (anaerobic, aerobic, and composting) is required for a broader removal of micropollutants (Alvarino et al., 2018; Butkovskyi et al., 2017). Micropollutants can be removed from the liquid phase by biodegradation (micropollutants are co-metabolized by microorganisms) and by adsorption and absorption (micropollutants are immobilized within the solid matter) (Alvarino et al., 2018). Sorption of micropollutants in anaerobic sludge was found to be minor (Butkovskyi et al., 2015), but for certain micropollutants, such as Doxycycline, Ciprofloxacin, Cetirizine, and Azithromycin, sorption (both adsorption and absorption depending on hydrophobicity and ionization) was observed (Table 7.3). Cetirizine and Azithromycin, which are both lipophilic or hydrophobic $(\log \mathrm{P}$ of 0.87 and 2.44, respectively), were more concentrated in the organic fraction than in the $\mathrm{CaP}$ granules. This is supported by the approximated concentration of Cetirizine and Azithromycin in CaP granules and organic fraction when based on volatile solids as shown in Table 7.3 (8.4 \pm 0.5 and $7.0 \pm$ $0.4 \mu \mathrm{g} \mathrm{kg}^{-1} \mathrm{VS}$ for Cetirizine and $0.7 \pm 0.4$ and $1.3 \pm 0.5 \mu \mathrm{g} \mathrm{kg}^{-1} \mathrm{VS}$ for Azithromycin, respectively). On the other hand, Doxycycline and Ciprofloxacin, which are both hydrophilic ( $\log \mathrm{P}$ of -3.29 and -0.85 , respectively) and negatively charged at pH 7.4 (gross charge 
distribution of -0.79 and -0.02 , respectively), were found in similar concentrations in the $\mathrm{CaP}$ granules and the organic fractions. Most likely, hydrophilic compounds adsorbed to both the $\mathrm{CaP}$ granules and the organic fraction by electrostatic interactions of the ionic groups (Alvarino et al., 2018). At pH below 8.5, HAP is positively charged (Bell et al., 1973). Lipophilic (hydrophobic) compounds were likely absorbed into the lipophilic microbial cell membrane and lipids in the flocculent sludge, inducing a higher concentration for the organic fraction than for the CaP granules (Alvarino et al., 2018). Both mechanisms (adsorption and absorption) are of concern regarding the incorporation of micropollutants in the $\mathrm{CaP}$ granules, because $29 \%$ of the CaP granules mass is still organic.

The level of micropollutants in $\mathrm{CaP}$ granules was relatively lower compared to reference ranges for SS and animal manure (Table 7.3). Animal manure is recycled on land for centuries, and human excreta or "night soil", as it used to be called in the ancient times, was also recycled on land until the development of permanent settlements (Lofrano and Brown, 2010). Then, the implementation of sewers drove the wastewater discharge to surface water instead of agriculture land (Ashley et al., 2011). Enabling the efficient recycling of nutrients and organic matter is crucial for the future sustainability of food production. The sum concentration of organic micropollutants measured in CaP granules was $4 \pm 1 \mathrm{mg} \mathrm{kg}^{-1} \mathrm{TS}$, from which $26 \%$ were antibiotics. The toxicity of these organic micropollutants even at very low levels is unknown. Moreover, the formation of unknown by-products from biotransformation and combination of pollutants arouses uncertainty regarding health safety. Because of the BW origin, industrial micropollutants, such as polychlorinated biphenyls (PCB), polychlorinated dibenzodioxins and dibenzofurans (PCDD/PCDF), and polycyclic aromatic hydrocarbons (PAH) are not expected to be present in $\mathrm{CaP}$ granules. The proposed regulation limits only the PAH to $<6 \mathrm{mg} \mathrm{kg}^{-1} \mathrm{TS}$ (European Commission, 2016).

Gell et al. (2011) measured a reduction of colony forming units (CFU) from 36200 $\mathrm{CFU} \mathrm{g} \mathrm{g}^{-1}$ in the influent $\mathrm{BW}$ to $100 \mathrm{CFU} \mathrm{g^{-1 }}$ of wet $\mathrm{UASB}$ sludge formed at $35^{\circ} \mathrm{C}$, which is lower than the proposed European regulatory limit of $1000 \mathrm{CFU} \mathrm{g}^{-1}$ (European Commission, 2016). However, generally, the average removal of pathogens, such as E. coli spp., Salmonella spp., and Enterococcus spp., during mesophilic treatment is only $2 \log$, which is not sufficient to ensure safety (Avery et al., 2014; Horan et al., 2004). Moreover, the unknown microbial speciation and the ascending concerns with spread of antibiotic resistant genes (ARG) during wastewater treatment introduces uncertainty and calls for research. By glowing $\mathrm{CaP}$ granules, pathogens and measured micropollutants will likely be disintegrated (Abouzeid, 2008). Then, 
the only pollutants remaining in glowed $\mathrm{CaP}$ granules are the heavy metals, which are below the regulatory limits.

\subsubsection{Usability of recovered CaP granules and $P$ market demands}

The direct use of $\mathrm{CaP}$ granules in agriculture is regulated in Europe by European legislation, which was recently revised to include waste streams as source for fertilizing products (European Commission, 2016). The revised regulation is structured according to Component Material Categories (CMC) and Product Function Categories (PFC). CaP granules are a CMC5 candidate, but the temperature during BW anaerobic digestion must be higher than $37^{\circ} \mathrm{C}$ and a pasteurization step at $70^{\circ} \mathrm{C}$ for $1 \mathrm{~h}$ must be performed to ensure reduction of pathogens (European Commission, 2016). Note that in this study CaP granules were produced at $25^{\circ} \mathrm{C}$. Another option to recognize $\mathrm{CaP}$ granules as $\mathrm{CMC} 5$ is the thermophilic $\left(55^{\circ} \mathrm{C}\right)$ anaerobic treatment of BW with an HRT longer than 20 days, followed by a test for the presence of pathogens. When the requirements for CMC5 category, which are connected to the process conditions, are fulfilled, the $\mathrm{CaP}$ granules can be directly used as $\mathrm{P}$ rich solid organic fertilizer (PFC1 AI), because they comply with the regulatory limits for heavy metals and organic pollutants.

Glowed CaP granules (15 wt $\%$ P or $34 \mathrm{wt} \% \mathrm{P}_{2} \mathrm{O}_{5}$ ), which are free of pathogens, can be processed with phosphate rock for production of water soluble fertilizer (TSP), decreasing the input of phosphate rock in agricultural land. Water soluble phosphate is used for production of liquid fertilizer, which is the most convenient form to spread on land. Although the production of $\mathrm{CaP}$ granules is decentralized, the glowing process (incineration at $800^{\circ} \mathrm{C}$ ) must be centralized for economic feasibility. To prevent contamination with heavy metals, monoincineration is recommended.

The production capacity versus the demand should be evaluated to estimate the real potential of $\mathrm{CaP}$ granules from $\mathrm{BW}$ in replacing phosphate rock on farmland or in the fertilizer industry. Assuming that $30 \mathrm{mgP} \mathrm{g}^{-1}$ of produced sludge $\left(0.12 \mathrm{gVSS} \mathrm{g}^{-1}\right.$ of total COD in the influent BW) will not yield CaP granules and that $10 \%$ of total incoming P from BW leave the anaerobic reactor with the effluent, $57 \%$ of the $\mathrm{P}$ in $\mathrm{BW}$ could potentially be harvested as $\mathrm{CaP}$ granules (Chapter 6). The remaining 33\% of the $\mathrm{P}$ fed is purged with excess sludge which could be used as solid amendment containing reduced P content ( $2 \mathrm{wt} \%)$ after composting as suggested by Butkovskyi et al. (2016). At an excretion of $0.44 \mathrm{kgP}$ person $^{-1}$ year $^{-1}$, the production capacity as $\mathrm{CaP}$ granules is $0.25 \mathrm{kgP}$ person ${ }^{-1}$ year $^{-1}$, which represents $12 \%$ of the worldwide annual consumption of phosphate rock per capita $\left(2 \mathrm{kgP}_{\text {person }}{ }^{-1} \mathrm{year}^{-1}\right)($ Cordell et al., 2009). However, the estimated global annual loss of phosphorus to the environment 
within agricultural activities $\left(\sim 15 \mathrm{Mt} \mathrm{P}\right.$ year $\left.^{-1}\right)$ is higher than the $\mathrm{P}$ input as phosphate rock (14 Mt P year ${ }^{-1}$ ), and only 8 and $17 \%$ of the $\mathrm{P}$ harvested as crops is actually consumed by humans with meat and vegetable-based diets, respectively (Cordell et al., 2009). Thus, the recovery of $\mathrm{P}$ from waste streams and the use efficiency of $\mathrm{P}$ in agricultural land are aspects determining the need of phosphate rock as mineral fertilizer. Improved $\mathrm{P}$ use efficiency could increase the capacity of $\mathrm{CaP}$ granules in replacing phosphate rock in agriculture.

\subsection{Conclusions}

In this study, $\mathrm{CaP}$ granules produced during anaerobic treatment of $\mathrm{BW}$ were assessed for chemical composition, structure, and crystallography, with the intent to demonstrating their potential use as a $\mathrm{P}$ recovery product. CaP granules contained $10 \mathrm{wt} \% \mathrm{P}$ (or $23 \mathrm{wt} \% \mathrm{P}_{2} \mathrm{O}_{5}$ ), corresponding to $55 \mathrm{wt} \%$ of HAP. By glowing, the remaining organic material (29 $\mathrm{wt} \%$ ) is removed, increasing the $\mathrm{P}$ content to $15 \mathrm{wt} \%$ (or $34 \mathrm{wt} \% \mathrm{P}_{2} \mathrm{O}_{5}$ ). Heavy metals $(\mathrm{Cu}, \mathrm{Zn}, \mathrm{Cr}, \mathrm{Ni}$, $\mathrm{Cd}, \mathrm{As}$, and $\mathrm{Pb}$ ) were below the European and Dutch regulatory limits. The total mass of micropollutants in $\mathrm{CaP}$ granules was $4 \mathrm{mg} \mathrm{kg}^{-1} \mathrm{TS}$, from which $26 \%$ was antibiotics and originate from consumption of pharmaceuticals. Considering the revised European regulation for fertilizing products, disinfected $\mathrm{CaP}$ granules can potentially be directly used as $\mathrm{P}$ rich solid organic fertilizer in agriculture. Dissolution tests showed that $35 \%$ of the $\mathrm{P}$ in $\mathrm{CaP}$ granules is released within $5 \mathrm{~min}$ in citric acid, while for phosphate rock only $14 \%$ of the $\mathrm{P}$ was released. Moreover, glowed $\mathrm{CaP}$ granules can replace phosphate rock in the fertilizer industry. 
Chapter 8. General discussion and outlook 


\subsection{Introduction}

The demand for resources rises with the growing world population (Alexander et al., 2015; Smajgl et al., 2016). Regarding energy, wind and solar power are proven sources of sustainable energy, despite their technological challenges (Schiermeier et al., 2008). For phosphorus $(\mathrm{P})$, the main source is natural phosphate rock $\left(\mathrm{P}\right.$ rock, $\left.\mathrm{Ca}_{5}\left(\mathrm{PO}_{4}\right)_{3} \mathrm{OH}\right)$, which is a finite natural resource with a predicted exploitation peak within 304 years (U.S. Geological Survey, 2015). Although the discovery of new reserves and the improvement of mining technologies can delay "peak P", there is no alternative to P rock in the natural environment. Therefore, finding alternatives and enabling their use is essential for the circular economy, global food security, and prosperity of humankind. The nowadays use of $\mathrm{P}$ rock is linear (from mine to fork), and $\mathrm{P}$ ends up in waste streams, such as manure and sewage, or runs-off to surface water (lakes and oceans).

Manure, which holds the larger fraction of used P (15 to $28 \mathrm{Mt} \mathrm{P}$ worldwide in 2009), is recycled at the farm level, but the excess of manure applied to the fields causes eutrophication of natural water courses due to P runoff (14 to $15 \mathrm{Mt} \mathrm{P}$ worldwide in 2009, representing 26\% of the global agricultural P input) (Cordell et al., 2009; Koppelaar and Weikard, 2013). For sewage (3 to 4.4 Mt P worldwide in 2009), the regulatory discharge limit enforces the P removal at the wastewater treatment plant (WWTP), minimizing the loss of P with the effluent to water courses, where P loses its economic usability (Cordell et al., 2009; Koppelaar and Weikard, 2013). The removed $\mathrm{P}$ is then concentrated in the solid fraction, but its direct use is limited by incorporation of contaminants (heavy metals, micropollutants, and pathogens) present in the sewage. The larger fraction of $\mathrm{P}$ in sewage is from human excreta (feces plus urine), about $1.3 \mathrm{gP}$ p.e. ${ }^{-1} \mathrm{~d}^{-1}$, representing approximately $68 \%$ of the total $\mathrm{P}$ in sewage (Tervahauta et al., 2013). By applying vacuum collection, the $\mathrm{P}$ concentration increases from $\sim 7 \mathrm{mgP} \mathrm{L}^{-1}$ in combined sewage (Tchobanoglous et al., 2004) to $~ 200 \mathrm{mgP}$ $\mathrm{L}^{-1}$ in black water (BW, feces plus urine) (Tervahauta et al., 2013). Besides $\mathrm{P}$, the organic content also increases from $\sim 0.4 \mathrm{gCOD} \mathrm{L}^{-1}$ in combined sewage (Tchobanoglous et al., 2004) to $\sim 10 \mathrm{gCOD} \mathrm{L}^{-1}$ in $\mathrm{BW}$, creating favorable conditions for simultaneous recovery of $\mathrm{P}$ and energy $\left(\mathrm{CH}_{4}\right)$, when BW is treated anaerobically.

This thesis unraveled and described the simultaneous recovery of calcium phosphate granules ( $\mathrm{CaP}$ granules) and methane gas $\left(\mathrm{CH}_{4}\right)$ from source separated $\mathrm{BW}$ in a single anaerobic treatment step. It was investigated how to optimize recovery and product characteristics. The final goal was to develop a novel treatment configuration for BW treatment 
in source separated sanitation (SSS), focusing on footprint reduction and production of a competitive alternative to replace mined $\mathrm{P}$ rock as fertilizer.

\subsection{Process and reactor development for CaP bio granulation}

After the introduction to the topic in Chapter 1, Chapters 2, 3, 4, and 5 describe the mechanism and required conditions for $\mathrm{CaP}$ bio granulation during anaerobic treatment of $\mathrm{BW}$ and synthetic wastewater with a similar chemical matrix (concentration of dissolved anions and cations) as BW, but different carbon source. The main insights into the formation and growth of $\mathrm{CaP}$ granules were then combined to develop a novel bioreactor design, which is presented in Chapter 6.

$\mathrm{CaP}$ bio granulation was firstly observed in a conventional upflow anaerobic sludge blanket (UASB) reactor by Tervahauta et al. (2014c) as presented in Figure 8.1. The operational upflow velocity was $0.6 \mathrm{~cm} \mathrm{~h}^{-1}$ to avoid washout of solids, enabling sufficient solids retention time (SRT) for degradation of particulate organic matter in BW. Because $70 \%$ of the $\mathrm{P}$ in $\mathrm{BW}$ is in the solid form, the solids retention capacity in the reactor is a crucial aspect. Moreover, the soluble calcium $\left(\mathrm{Ca}^{2+}\right)$ in $\mathrm{BW}$ was not sufficient to trap the soluble phosphorus $\left(\mathrm{PO}_{4}{ }^{3-}\right)$. Therefore, supplementation of $\mathrm{Ca}^{2+}\left(250 \mathrm{mg} \mathrm{L}^{-1}\right.$ of $\left.\mathrm{BW}\right)$ is required to ensure sufficient $\mathrm{P}$ removal during the treatment (Chapter 3). With the conventional UASB reactor and $\mathrm{Ca}^{2+}$ addition, $90 \%$ of the total $\mathrm{P}$ was retained in the reactor, and $95 \%$ of the total COD was removed with a methanization rate of $47 \%$. Without $\mathrm{Ca}^{2+}$ addition, the total $\mathrm{P}$ removal was between 51 and $72 \%$, depending on the $\mathrm{Ca}^{2+}$ concentration in the influent $\mathrm{BW}$ (Cunha et al., 2017; Tervahauta et al., 2014c). With $\mathrm{Ca}^{2+}$ addition, the harvested $\mathrm{CaP}$ granules (> $0.4 \mathrm{~mm}$ diameter) corresponded to at least $31 \%$ of the total incoming $\mathrm{P}$, but they were not fully mature. The granule growth mechanism is described in Chapter 4 and clarifies that large granules (> $2.5 \mathrm{~mm}$ diameter with $5 \mathrm{wt} \%$ of $\mathrm{P}$ ) are younger than smaller but more compact granules ( 0.9 to $2.5 \mathrm{~mm}$ diameter with $7 \mathrm{wt} \%$ of $\mathrm{P})$. Moreover, the larger size fraction contains more organic material than the size fraction between 0.9 and $2.5 \mathrm{~mm}$ in diameter. Thus, the separation of granules $>0.4 \mathrm{~mm}$ diameter using a conventional UASB reactor is not ideal, because there is no selection for mature over less mature $\mathrm{CaP}$ granules.

In Chapter 5, it is shown that bulk $\mathrm{pH}$ and carbon source are key factors for the formation of $\mathrm{CaP}$ granules. The production of extracellular biopolymers (EPS) enhances agglomeration of microorganisms and calcium phosphate $\left(\mathrm{Ca}_{\mathrm{x}}\left(\mathrm{PO}_{4}\right)_{\mathrm{y}}\right)$ fine particles, containing amorphous calcium phosphate phases and hydroxyapatite nanocrystals. With the decay of organic material in the center of the agglomerate, $\mathrm{Ca}_{\mathrm{x}}\left(\mathrm{PO}_{4}\right)_{\mathrm{y}}$ clusters concentrate in 
the core and are covered by new biomass (EPS and microbial cells), developing an outer biofilm with methanogenic activity. Consequently, a $\mathrm{pH}$ gradient from 7.5 at the edge to 7.9 in the core of the granules is biologically induced. The $\mathrm{pH}$ gradient favors enrichment of $\mathrm{Ca}_{\mathrm{x}}\left(\mathrm{PO}_{4}\right)_{\mathrm{y}}$ in the granules over bulk precipitation (Chapter 4). For instance, a bulk pH $>7.8$ induces $\mathrm{Ca}_{\mathrm{x}}\left(\mathrm{PO}_{4}\right)_{\mathrm{y}}$ and $\mathrm{CaCO}_{3}$ precipitation in the bulk of the reactor, limiting the favored $\mathrm{P}$ enrichment in the granules. Therefore, bulk pH should be kept $<7.8$ and the contact between flocculent sludge (microorganisms and EPS) and $\mathrm{Ca}_{\mathrm{x}}\left(\mathrm{PO}_{4}\right)_{\mathrm{y}}$ should occur to stimulate formation and growth of $\mathrm{CaP}$ granules.

Chapter 6 demonstrates that by applying mixing, organic and fine inorganic particles can be separated from larger inorganic particles, increasing the concentration of $\mathrm{CaP}$ granules at the bottom of the reactor (harvesting location). For the mixing, a novel bioreactor design combining UASB and gas-lift technologies (UASB-GL) was used (Figure 8.1). The lifting of lighter particles from the bottom enhances the local concentration of denser $\mathrm{CaP}$ granules. Then, lifted fine inorganic and organic particles become part of the flocculent sludge higher in the reactor, stimulating further formation and growth of $\mathrm{CaP}$ granules. The mixing also contributes to a reduction in the organic content in the granules by increasing the particle to particle friction, decreasing the biofilm thickness around the granule. When comparing the UASB-GL reactor with a non-mixed UASB reactor (Chapter 6), it is shown that the solid concentration of $\mathrm{P}$ at the bottom of the reactor increased $53 \%$, from 3.0 to $4.6 \mathrm{gP} \mathrm{kg}^{-1}$ of sludge, and the $\mathrm{P}$ content in $\mathrm{CaP}$ granules (> $0.4 \mathrm{~mm}$ diameter) at the harvesting location increased $16 \%$, from 6.7 to $7.8 \mathrm{wt} \%$.

Regarding the treatment efficiency, the total COD removal was $\sim 90 \%$ in the novel reactor. Accumulation of volatile fatty acids (VFA) in the effluent was never observed. Methanization (gCOD-CH $\mathrm{g}^{-1} \mathrm{COD}_{\text {Total }}-\mathrm{BW}$ ) was lower in the UASB-GL reactor, contrasting the measured long SRT. The lower methanization could be due to the use of BW with a lower biodegradability. Latter corresponds with the high sludge production $\left(0.12 \mathrm{gVSS} \mathrm{g}^{-1} \mathrm{COD}_{\text {Total- }}{ }^{-}\right.$ $\mathrm{BW}$ ) measured in the UASB-GL reactor, reducing the concentration of active methanogens in the sludge. 
In summary, the proven advantages of the UASB-GL reactor over a non-mixed UASB reactor are:

- $\mathrm{P}$ richer $\mathrm{CaP}$ granules at the harvesting location

- Higher total concentration of $\mathrm{P}$ at the bottom of the reactor (harvesting location)

- Stimulation of $\mathrm{CaP}$ bio granulation by increasing the contact between dispersed sludge and inorganic seed particles

- Lower concentration of $\mathrm{P}$ at the top part of the reactor, enabling the purge of excess of sludge with low $\mathrm{P}$ content
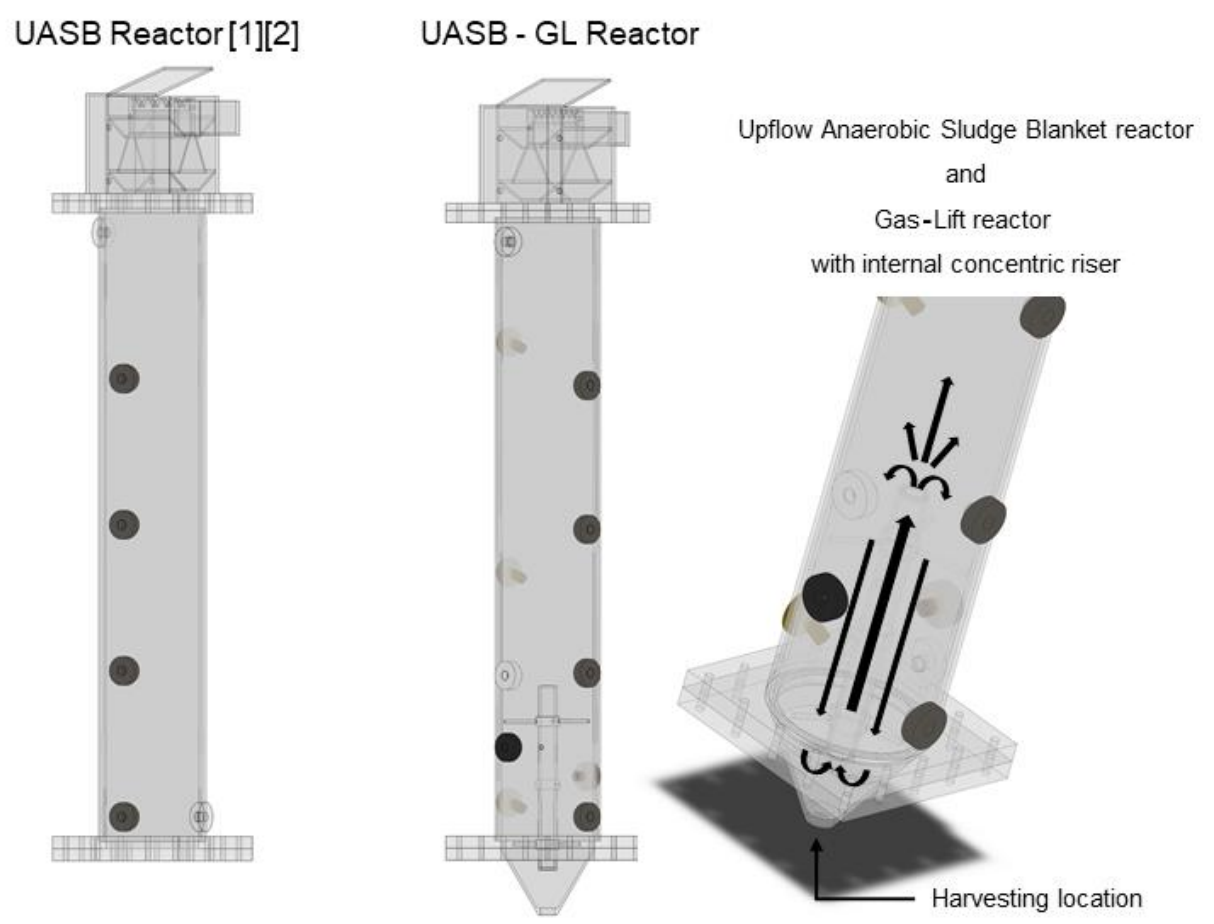

Figure 8.1 UASB reactor model used in the studies of [1] Graaff et al. (2010) and [2] Tervahauta et al. (2014c) and the combined UASB and gas lift reactor (GLR), which was developed in this study for internal recirculation of liquid and for concentration of mature $\mathrm{CaP}$ granules at the harvesting location. 


\subsubsection{Process and reactor improvements}

The 300 days of operation and monitoring of the UASB-GL reactor showed that simultaneous recovery of $\mathrm{CaP}$ granules and $\mathrm{CH}_{4}$ from $\mathrm{BW}$ with internal gas recirculation is possible (Chapter 6). However, there are aspects for further optimization of the reactor operation.

\subsubsection{Gas recirculation}

We used $\mathrm{N}_{2}$ as the recirculation gas, but the ultimate goal is the reuse of produced biogas. A compressor could be used to loop the biogas back into the UASB-GL reactor, and by controlling the pressure build-up, the biogas surplus is then recovered.

\subsubsection{Geometry of the riser and gas volumetric flow}

The presence of particles $<0.4 \mathrm{~mm}$ diameter at the bottom of the reactor was caused by the higher viscosity of the sludge ( $1 \mathrm{~Pa}$ s, corresponding to $\sim 60 \mathrm{gTSS} \mathrm{L}^{-1}$ ) when compared to water $\left(0.9 \times 10^{-3} \mathrm{~Pa} \mathrm{~s}\right)$, reducing the liquid velocity and the upward drag force at the bottom of the riser. Thus, the upward drag force at the bottom of the riser needs to be increased to enable the lifting of small particles $(<0.4 \mathrm{~mm}$ diameter). Increasing the recirculation flow of gas $\left(0.3 \mathrm{~L} \mathrm{~min}^{-1}\right.$ in this study) is an option to directly enhance the lifting force at the bottom of the reactor. Furthermore, design aspects, such as the geometry of the bottom cone (settling angle), the diameter of the riser $\left(\mathrm{d}_{\mathrm{r}}\right)$, and distance from the riser to the bottom of the reactor $\left(h_{\mathrm{r}}\right)$, can be optimized to enhance the lifting force. The COMSOL model described in Chapter 6 was also used to redesign the geometry of the bottom of the reactor and riser to enhance the lifting force (upward liquid velocity). For instance, an increase in the $\mathrm{N}_{2}$ gas flow to $1.3 \mathrm{~L} \mathrm{~min}$ ${ }^{1}$ resulted in an increase of upward liquid velocity at the bottom of the riser from 20 to $40 \mathrm{~m} \mathrm{~h}$ ${ }^{1}$ (Figure 8.2a and b). At $0.3 \mathrm{~L} \mathrm{~min}^{-1}$, a decrease of $h_{\mathrm{r}}$ from 4 to $1 \mathrm{~cm}$ resulted in an increase of upward liquid velocity at the bottom of the reactor from $<10$ to $\sim 20 \mathrm{~m} \mathrm{~h}^{-1}$ (Figure 8.2a and c). When the gas flow is increased to $1.3 \mathrm{~L} \mathrm{~min}^{-1}$, the liquid velocity further increases to $\sim 30$ $\mathrm{m} \mathrm{h}^{-1}$ at the bottom (Figure 8.2d). Note that by lowering the riser the settling angle of the bottom cone increased from $60^{\circ}$ to $70^{\circ}$; otherwise the path length between the reactor outer wall and riser was not sufficient. A decrease in the $d_{r}$ from 2.6 to $1.3 \mathrm{~cm}$ resulted in an increased upward liquid velocity in the riser, but the lifting force at the bottom of the reactor decreased due to the reduction in liquid volumetric flow in the riser (Figure 8.2e). With $\mathrm{h}_{\mathrm{r}}$ of $2 \mathrm{~cm}, \mathrm{~d}_{\mathrm{r}}$ of $2.6 \mathrm{~cm}$, and gas flow of $2 \mathrm{~L} \mathrm{~min}^{-1}$, the upward liquid velocities in the riser and at the bottom of the reactor reached 90 and $40 \mathrm{~m} \mathrm{~h}^{-1}$, respectively. In Chapter 7, we have shown that an upward liquid velocity of $76 \mathrm{~m} \mathrm{~h}^{-1}$ gives sufficient shear to increase the $\mathrm{P}$ content of $\mathrm{CaP}$ granules by $28 \%$ (from 7.8 to $10 \mathrm{wt} \%$ ). Thus, a combination of the proposed options could be 
implemented to ensure similar liquid velocities at the bottom of the reactor. Note that the injection of the gas must be inside the riser to ensure the difference in gas hold up between the downcomer and riser (Figure 8.2f). For instance, the injection of gas at the very bottom of the reactor does not yield the required loop recirculation (tested by simulation, but results not shown).

\subsubsection{Replacing $\mathrm{CaCl}_{2}$ by $\mathrm{CaCO}_{3}$}

As a consequence of the addition of $\mathrm{CaCl}_{2}$, the $\mathrm{Cl}^{-}$concentration in the UASB effluent increases from $439 \pm 40$ to $834 \pm 191 \mathrm{mg} \mathrm{L}^{-1}$. Considering that discharge of $\mathrm{Cl}$ is regulated, the effluent disposal can become an issue. The addition of $\mathrm{CaOH}_{2}$ is not an option due to the increase in bulk $\mathrm{pH}$, which probably disrupts the increasing $\mathrm{pH}$ gradient in the $\mathrm{CaP}$ granules and consequently, the enrichment of $\mathrm{Ca}_{x}\left(\mathrm{PO}_{4}\right)_{\mathrm{y}}$ in the granules. Thus, we propose to replace the $\mathrm{CaCl}_{2}$ with $\mathrm{CaCO}_{3}$ seed particles. When the bulk pH is sufficiently low $(<7.5)$, the exchange of $\mathrm{Ca}^{2+}$ ions between $\mathrm{CO}_{3}{ }^{2-}$ and $\mathrm{PO}_{4}{ }^{3-}$ at the seed surface is possible (Rokidi et al., 2011). Because $\mathrm{PO}_{4}{ }^{3-}(\mathrm{pKa}=12)$ is replaced by $\mathrm{CO}_{3}{ }^{2-}(\mathrm{pKa}=10)$ in reactor bulk solution variation in $\mathrm{pH}$ is expected to be minor, but it should be evaluated within the $\mathrm{BW}$ chemical matrix, including the stoichiometry and rates between $\mathrm{CO}_{3}{ }^{2-}$ dissolution from $\mathrm{CaCO}_{3}$ and $\mathrm{PO}_{4}{ }^{3-}$ precipitation as $\mathrm{Ca}_{\mathrm{x}}\left(\mathrm{PO}_{4}\right)_{\mathrm{y}}$. The relatively long SRT of the granules at the bottom of the reactor (578 days) facilitates the substitution of $\mathrm{CaCO}_{3}$ by $\mathrm{Ca}_{\mathrm{x}}\left(\mathrm{PO}_{4}\right)_{\mathrm{y}}$. 
a)

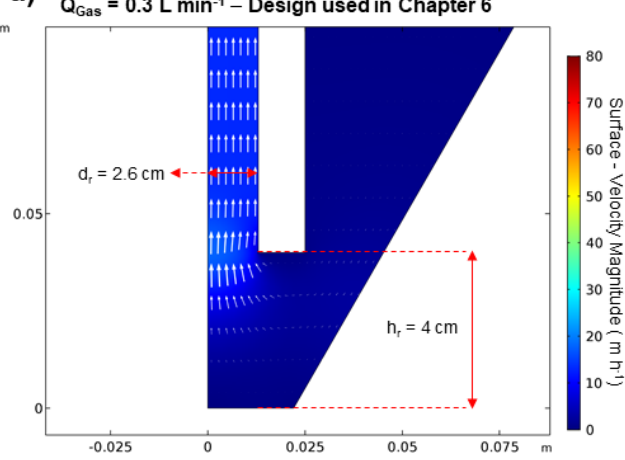

c)

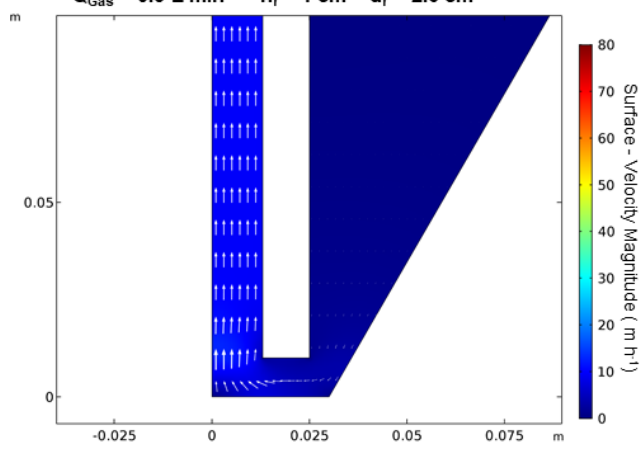

e) $Q_{G a s}=1.3 L \mathrm{~min}^{-1}-h_{r}=1 \mathrm{~cm}-d_{r}=1.3 \mathrm{~cm}$

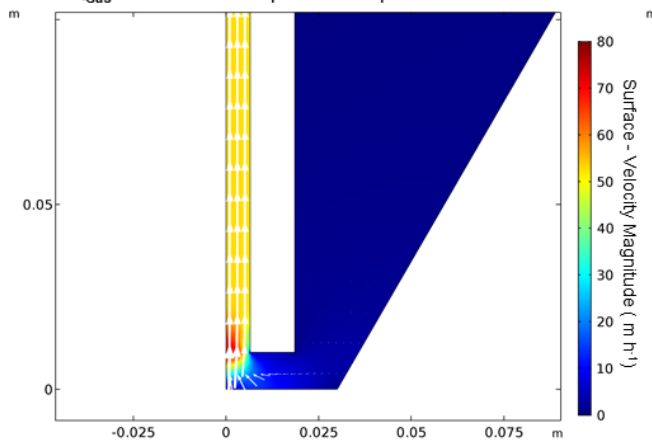

b) $Q_{G a s}=1.3 L^{-1} \min ^{-1}-h_{r}=4 \mathrm{~cm}-d_{r}=2.6 \mathrm{~cm}$

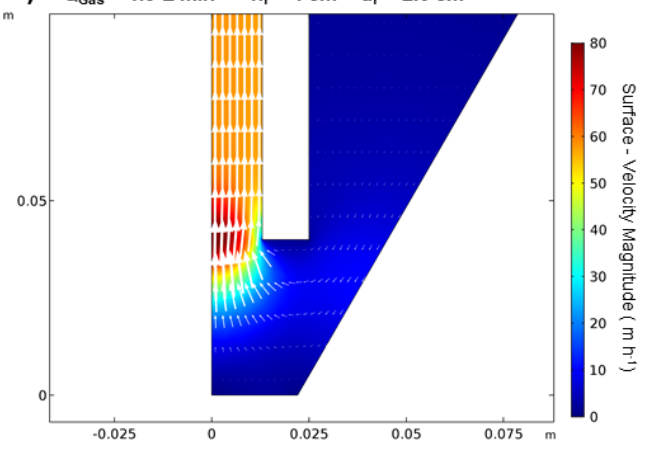

d) $Q_{G a s}=1.3 \mathrm{~L} \mathrm{~min}^{-1}-\mathrm{h}_{\mathrm{r}}=1 \mathrm{~cm}-\mathrm{d}_{\mathrm{r}}=2.6 \mathrm{~cm}$

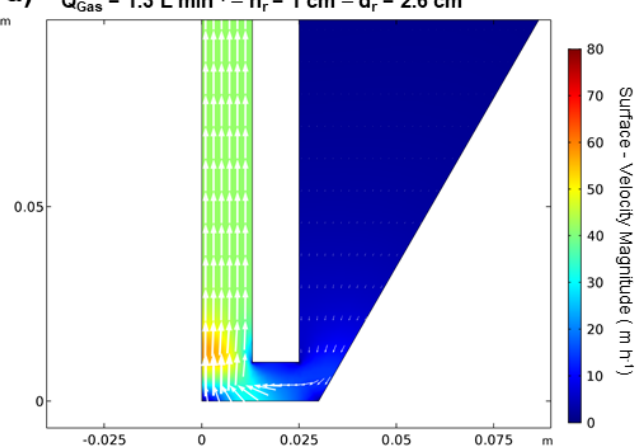

f) $Q_{G a s}=2 L m^{-1}-h_{r}=2 c m-d_{r}=2.6 \mathrm{~cm}$

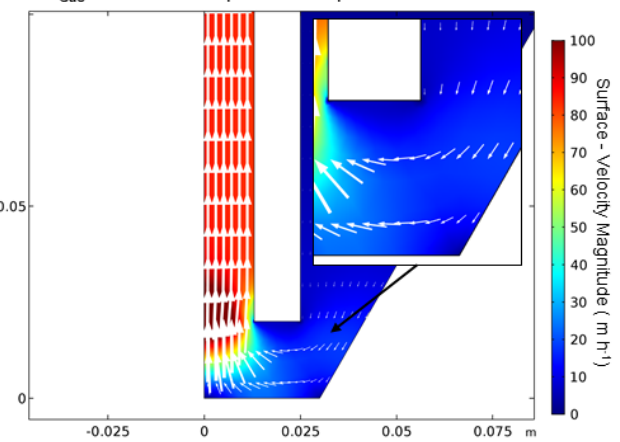

Figure 8.2 COMSOL simulations of liquid flow direction (arrows) and velocity magnitude (surface colors) for changes in volumetric gas flow $\left(\mathrm{Q}_{\mathrm{Gas}}\right)$, height of the riser from the bottom of the reactor $\left(h_{r}\right)$ and diameter of the riser $\left(d_{r}\right)$. Model settings were as in Chapter 6 . 


\subsubsection{Recovery efficiency}

Regarding recovery of $\mathrm{CH}_{4}$, we have shown that the addition of $\mathrm{Ca}^{2+}$ and the new design are not limiting the treatment performance, and therefore, not affecting $\mathrm{CH}_{4}$ production. The $\mathrm{CH}_{4}$ production from source separated BW $\left(6 \mathrm{~L}\right.$ p.e. $\left.{ }^{-1} \mathrm{~d}^{-1}\right)$ is approximately $12 \mathrm{~L}_{\mathrm{CH}_{4}}$ p.e. ${ }^{-1}$ $\mathrm{d}^{-1}$, representing $0.4 \mathrm{MJ}$ p.e. ${ }^{-1} \mathrm{~d}^{-1}$ (Chapter 2 and 3).

Regarding the recovery of $\mathrm{P}$, it is shown that approximately $90 \%$ of the total $\mathrm{P}$ in $\mathrm{BW}$ was retained in the sludge during the anaerobic treatment by adding $\mathrm{Ca}^{2+}$ (Chapter 3 and 6). The effluent total $\mathrm{P}$ concentration was on average $20 \mathrm{mg} \mathrm{L}^{-1}$. Based on results from Chapter 6 , the recovery of $\mathrm{CaP}$ granules from the UASB-GL reactor represents $57 \%$ of the total $\mathrm{P}$ in $\mathrm{BW}$ $\left(0.25 \mathrm{kgP}\right.$ p.e. ${ }^{-1} \mathrm{y}^{-1}$ for a BW production of $6 \mathrm{~L} \mathrm{p.e.}{ }^{-1} \mathrm{~d}^{-1}$ containing $\left.0.2 \mathrm{gP} \mathrm{L} \mathrm{L}^{-1}\right)$. The remaining $\mathrm{P}(33 \%)$ is in excess of sludge purged from the upper part of the reactor. Optimization of reactor design and dimensions can reduce the latter and increase the $\mathrm{P}$ recovery efficiency as $\mathrm{CaP}$ granules.

\subsection{Implementation within the current source separated sanitation}

The current treatment scheme for BW in SSS applied in the Netherlands is presented in Figure 8.3a (Graaf and Hell, 2014; Graaff et al., 2010). After vacuum collection and transport, BW is treated in a UASB reactor for removal of COD. Then, $\mathrm{N}$ is removed in an Oxygen-Limited Autotrophic Nitrification Denitrification (OLAND) reactor (Vlaeminck et al., 2009), which consists of a rotating biological contactor with a biofilm containing biomass capable of nitritation of ammonium $\left(\mathrm{NH}_{4}^{+}\right)$at oxygen-limiting conditions and conversion of produced nitrite $\left(\mathrm{NO}_{2}{ }^{-}\right)$and $\mathrm{NH}_{4}{ }^{+}$to $\mathrm{N}_{2}$ by anammox bacteria. Finally, $\mathrm{P}$ is removed by adding $\mathrm{MgO}$ to precipitate struvite in a crystallizer. The effluent from the BW treatment is combined with gray water for post-treatment, but this might limit the reuse of gray water due to contamination with heavy metals, pharmaceuticals, and pathogens. The implementation of the $\mathrm{CaP}$ bio granulation process (Figure 8.3b) shortens the treatment line for BW, by avoiding an additional treatment step for $\mathrm{P}$ removal.

The struvite effluent from the conventional BW treatment in the demonstration plant in Sneek (the Netherlands) contains on average $0.3 \mathrm{gCOD}_{\text {Total }} \mathrm{L}^{-1}$ and $20 \mathrm{mgP}_{\text {Total }} \mathrm{L}^{-1}$ (Graaf and Hell, 2014). The combined P removal is $90 \%$, from which $39 \%$ is accumulated in the UASB reactor (Graaff et al., 2011a), 3\% is removed in OLAND reactor (Graaf and Hell, 2014), and $48 \%$ is retained in the struvite crystallizer (Graaff et al., 2011a). The effluent $\operatorname{COD}_{\text {Total }}$ and $\mathrm{P}_{\text {Total }}$ concentrations from the anaerobic treatment with the CaP bio granulation process are on average 640 and $20 \mathrm{mg} \mathrm{L}^{-1}$, respectively (Chapter 3 and 6). According to Graaf and Hell (2014) 
about $50 \%$ and $3 \%$ of the $\mathrm{COD}_{\text {Total }}$ and $\mathrm{P}_{\text {Total }}$ in the UASB effluent, respectively, are retained in the $\mathrm{N}$ removal stage. Thus, the effluent concentrations for both schemes are similar. However, when $\mathrm{P}$ is directly recovered in the UASB reactor, the fraction of P retained in the UASB reactor (> 39\%) can potentially be recovered as CaP granules, yielding a higher recovery efficiency when compared to struvite precipitation in a separate treatment step.

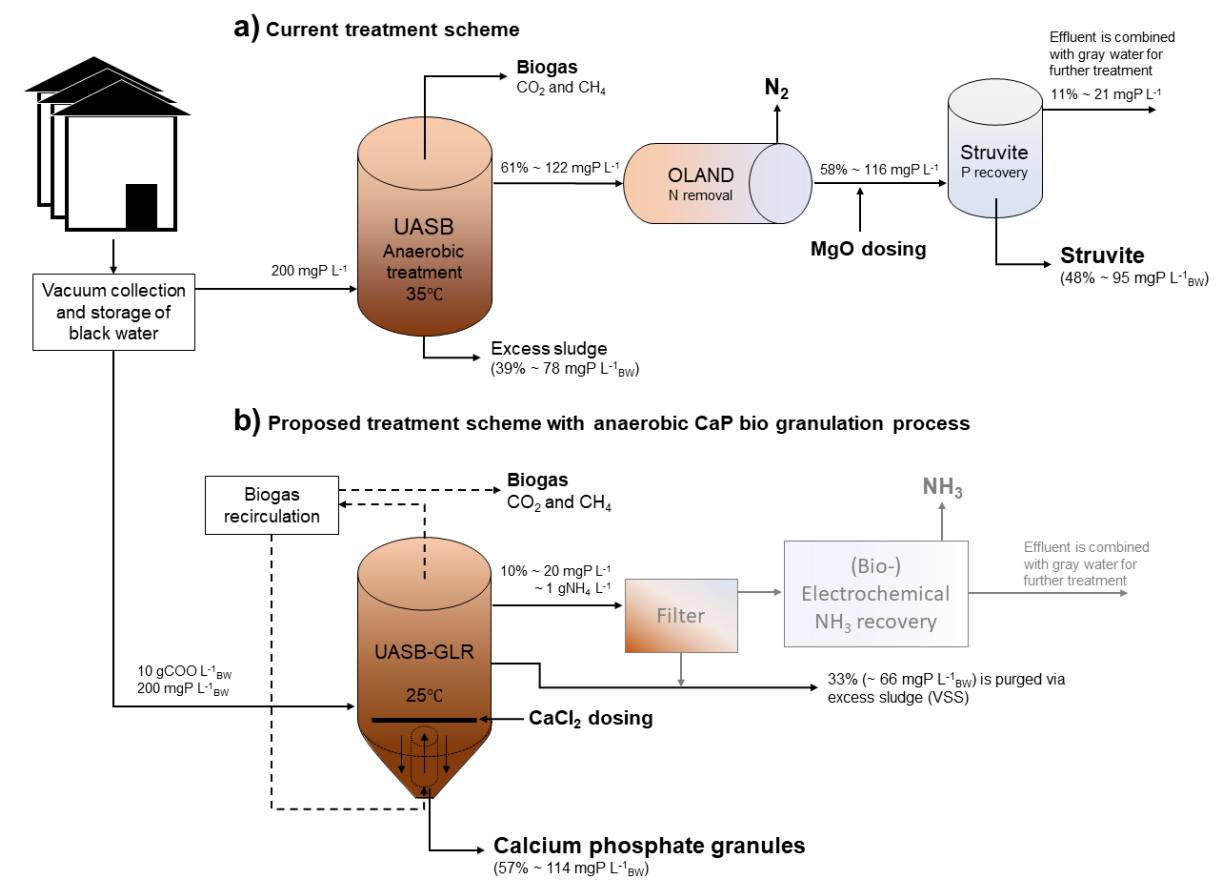

Figure 8.3 Treatment scheme for black water in the current concept for source separated sanitation in the Netherlands (Graaf and Hell, 2014) (a), and proposed treatment concept considering implementation of anaerobic calcium phosphate bio granulation and (bio-) electrochemical ammonia $\left(\mathrm{NH}_{3}\right)$ recovery (Kuntke et al., 2018) (b). COD and P mass balances are included in both schemes according to Graaff et al. (2010) and Graaff et al. (2011a)for a and Chapter 6 for $b$.

\subsubsection{Economic assessment}

Regarding $\mathrm{P}$ recovery, the implementation of the $\mathrm{CaP}$ bio granulation process demands the addition of $250 \mathrm{mgCa}^{2+} \mathrm{L}^{-1}$ of $\mathrm{BW}$ (or $2.2 \mathrm{~g} \mathrm{~g}^{-1}$ per $\mathrm{P}$ recovered), considering an influent $\mathrm{Ca}^{2+}$ concentration in raw $\mathrm{BW}$ of $53 \mathrm{mg} \mathrm{L}^{-1}$; the $\mathrm{Ca}^{2+}$ concentration might be higher for locations with harder tap water (up to $575 \mathrm{mgCa}^{2+} \mathrm{L}^{-1}$ for mineral water), and therefore, requiring less $\mathrm{Ca}^{2+}$ addition (Azoulay et al., 2001). For the BW composition in this study, the associated cost for the addition of $\mathrm{Ca}^{2+}\left(\mathrm{CaCl}_{2}\right)$ is $0.18 €$ p.e. ${ }^{-1} \mathrm{y}^{-1}$, representing $0.72 € \mathrm{~kg}^{-1}$ of $\mathrm{P}$ recovered $\left(\mathrm{CaCl}_{2}\right.$ prices from Alibaba.com in June 2018). Using $\mathrm{CaCO}_{3}$ instead of $\mathrm{CaCl}_{2}$ 
would reduce the cost to $0.09 €$ p.e. ${ }^{-1} \mathrm{y}^{-1}\left(\mathrm{CaCO}_{3}\right.$ prices from Alibaba.com in August 2018), but it can be lower because $\mathrm{CaCO}_{3}$ is a waste material during softening of drinking water and it could be reused. The cost estimation was based on the results from Chapter 6 . The further optimization of the UASB-GL reactor and potential increase in the recovery efficiency (57\%) could lower the presented cost.

Similarly, $\mathrm{P}$ recovery as struvite requires the addition of $127 \mathrm{mgMg}^{2+} \mathrm{L}^{-1}\left(\mathrm{Mg} / \mathrm{PO}_{4}{ }^{3-}\right.$ molar ratio of 1.5 (Graaff et al., 2011a)) when treating the OLAND effluent, representing 1.4 $\mathrm{gMg}^{2+} \mathrm{g}^{-1}$ of $\mathrm{P}$ recovered and considering a $\mathrm{Mg}^{2+}$ concentration in the OLAND effluent of 13 $\mathrm{mg} \mathrm{L}^{-1}$ (Chapter 3). Then, the associated cost for the addition of $\mathrm{Mg}(\mathrm{MgO})$ is $0.11 €$ p.e. ${ }^{-1} \mathrm{y}^{-}$ ${ }^{1}$, representing $0.54 € \mathrm{~kg}^{-1}$ of $\mathrm{P}$ recovered (MgO prices from Alibaba.com in June 2018). The input values are based on the anaerobic treatment of $\mathrm{BW}$ without kitchen waste $\left(0.2 \mathrm{gP} \mathrm{L}^{-1} \mathrm{BW}\right.$ for a BW production of $6 \mathrm{~L}$ p.e. ${ }^{-1} \mathrm{~d}^{-1}$ and $58 \%$ of the $\mathrm{P}$ in $\mathrm{BW}$ is in the influent for the struvite crystallizer (Graaff et al., 2010)). The estimated $\mathrm{P}$ recovery as struvite $\left(0.21 \mathrm{kgP}\right.$ p.e. $\left.{ }^{-1} \mathrm{y}^{-1}\right)$ represents $48 \%$ of the $\mathrm{P}_{\text {Total }}$ in $\mathrm{BW}$. Although the operational cost for the $\mathrm{P}$ recovery as struvite is lower, the $\mathrm{P}$ production as $\mathrm{CaP}$ granules is $19 \%$ higher $\left(0.25 \mathrm{kgP} \mathrm{p} . \mathrm{e}^{-1} \mathrm{y}^{-1}\right)$, considering the presented recovery efficiency in Chapter 6 . A possible increase of $\mathrm{Ca}^{2+}$ in tap water used for toilet flushing would increase the retention of $\mathrm{P}$ in the anaerobic reactor and consequently, decrease the $\mathrm{P}$ recovery efficiency as struvite and decrease the cost for $\mathrm{P}$ recovery as $\mathrm{CaP}$ granules.

The combination of $\mathrm{P}$ recovery and anaerobic treatment in a single reactor prevents the use of an additional reactor for P removal, reducing the capital expenditures (CAPEX) directly. The operation expenditures (OPEX) for struvite production, which are mainly related to the systems for fluidization and $\mathrm{Mg}$ dosage, are considered similar as those for the production of $\mathrm{CaP}$ granules (systems for $\mathrm{Ca}$ dosage and recycling of biogas). Thus, implementation of the CaP bio granulation process within the current SSS scheme is not expected to change the OPEX significantly but contribute to a reduction in CAPEX, which has a higher share (60\%) from the total costs according to Roefs et al. (2017). Furthermore, the combined recovery of $\mathrm{P}$ and $\mathrm{CH}_{4}$ is one treatment step is easier to operate.

\subsubsection{Resource recovery in source separated sanitation}

The resource recovery possibilities when separating BW and gray water at the source have advantages when compared to centralized conventional sanitation for two main reasons: (1) increasing concentration of organic matter and nutrients and (2) reducing the concentration of heavy metals and micropollutants in BW, by its separation from gray water, industrial wastewater, and runoff water from streets. 
Regarding energy, the relatively high concentration of organic matter enables anaerobic treatment in countries with low ambient temperatures and the subsequent local production of heat and electricity, which are at least sufficient to cover the energy demand of the treatment (Graaff et al., 2011a). Furthermore, the energy recovery by gray water heat exchange is an added value for SSS. Addition of ground kitchen waste at the start of the black water treatment line, which is already performed in the demonstration treatment plant in Sneek (Graaf and Hell, 2014), can increase the energy potential (higher $\mathrm{CH}_{4}$ production) and the $\mathrm{P}$ recovery by $15 \%$ (considering a load of $\mathrm{P}$ in kitchen waste of $0.2 \mathrm{~g} \mathrm{p.e.}{ }^{-1} \mathrm{~d}^{-1}$ ) (Tervahauta et al., 2013). The production of $\mathrm{CaP}$ granules enables either the direct $\mathrm{P}$ recycling in the surrounding agricultural area or the $\mathrm{P}$ transport to other regions/countries by centralized collection and upgrading (e.g., glowing) of $\mathrm{CaP}$ granules, considering a $\mathrm{P}$ content in the glowed granules similar to $\mathrm{P}$ rock $\left(34 \mathrm{wt} \% \mathrm{P}_{2} \mathrm{O}_{5}\right.$ ). Another nutrient which could potentially be recovered is $\mathrm{N}$ ( 0.8 to $1 \mathrm{gNH}_{4}{ }^{+}-\mathrm{N} \mathrm{L}^{-1}$ UASB effluent). Currently, $\mathrm{N}$ is removed from BW as $\mathrm{N}_{2}$ gas in an OLAND system (Graaf and Hell, 2014). However, $\mathrm{N}$ could be recovered as ammonia $\left(\mathrm{NH}_{3}\right)$ using a (bio-) electrochemical system as proposed in Figure 8.3 (Kuntke et al., 2018). Potassium $\left(\mathrm{K}^{+}\right)$is the other major component in fertilizers $(\mathrm{N}, \mathrm{P}$, and $\mathrm{K})$ and also a finite resource. In $\mathrm{BW}$, the $\mathrm{K}^{+}$concentration is in average $300 \mathrm{mg} \mathrm{L}^{-1}$. An ion exchange membrane could perhaps recover $\mathrm{K}^{+}$, but further research is required to study process feasibility ( $\mathrm{Li}$ et al., 2015). Besides energy and nutrients, water itself becomes a resource in SSS, due to the possibility of gray water reuse. For countries experiencing water scarcity, enabling the water reuse is economically interesting, especially when it reduces the consumption of treated fresh surface water, which is the main water reservoir affected by weather conditions (Schlosser et al., 2014).

\subsubsection{Less water for toilet flush}

The volume of water used for vacuum toilet flush ( $1 \mathrm{~L}$ in this study) dictates the design parameters for the biological treatment because it affects the concentration factor of BW. For instance, a reduction from $1 \mathrm{~L}$ to $0.25 \mathrm{~L}$ of water per flush, would increase the concentration of organic matter and phosphorus by a factor of 4 , giving $38 \mathrm{gCOD} \mathrm{L}^{-1}$ and 0.7 $\mathrm{gP} \mathrm{L}^{-1}$. Then, a longer operational hydraulic retention time (HRT) should be applied to ensure similar loading rates and solids retention time (SRT), and therefore, similar COD conversion; hydrolysis of the particulate organic matter is the limiting step for the anaerobic digestion of $\mathrm{BW}$. Thus, a reduction of daily volumetric flow for BW does not mean a reduction in required reactor volume when applying a UASB reactor but does enable the increase of the process temperature as less water is to be heated. The SRT required for hydrolysis of the particulate 
organic matter is expected to be shorter when applying thermophilic $\left(55^{\circ} \mathrm{C}\right)$ or hyperthermophilic $\left(70^{\circ} \mathrm{C}\right)$ anaerobic treatment, enabling a reduction in reactor volume (Algapani et al., 2016). However, at $55^{\circ} \mathrm{C}$ and $70^{\circ} \mathrm{C}$, the viscosity of the anaerobic sludge, the biological production of EPS, the microbial growth and speciation, and the thermodynamic conditions for precipitation of $\mathrm{Ca}_{x}\left(\mathrm{PO}_{4}\right)_{y}$ are affected. Regarding $\mathrm{Ca}_{\mathrm{x}}\left(\mathrm{PO}_{4}\right)_{\mathrm{y}}$ precipitation, an increase from $25^{\circ} \mathrm{C}$ to $70^{\circ} \mathrm{C}$ increases the saturation index (SI) for amorphous calcium phosphate (ACP) and octacalcium phosphate (OCP), both precursors of apatite (AP), by a factor of 7 and 12, respectively. Theoretically, $\mathrm{Ca}_{\mathrm{x}}\left(\mathrm{PO}_{4}\right)_{\mathrm{y}}$ precipitation is enhanced by higher temperatures which could trigger unwanted bulk precipitation. For the competing precipitate $\mathrm{CaCO}_{3}$ (calcite), the increase in temperature from $25^{\circ} \mathrm{C}$ to $70^{\circ} \mathrm{C}$ increases the SI by a factor of 1.2, indicating that $\mathrm{CaCO}_{3}$ precipitation is less favored at higher temperature than $\mathrm{Ca}_{\mathrm{x}}\left(\mathrm{PO}_{4}\right)_{\mathrm{y}}$. The chemical matrix of BW presented in Chapter 2 was used as input components for the SI model calculation.

The utmost objective of less water use for toilet flush is the increase of organic matter concentration in BW, enabling application of high operational temperature for reduction of pathogens; this is part of the European project Run4Life, which is financed by the EU Horizon 2020 Research and Innovation programme (European Commission, 2017). The reduction of pathogens from $\mathrm{BW}$ is achieved at $70^{\circ} \mathrm{C}$, but attention should be given to the formation of spores, which is a mechanism of survival for some pathogenic microorganisms (Russell, 2003). The hyperthermophilic anaerobic treatment of BW could be combined with CaP bio granulation to produce pathogen-free $\mathrm{CaP}$ granules potentially. Further research is necessary to demonstrate whether $\mathrm{CaP}$ bio granulation is possible at a higher temperature.

\subsection{Market for calcium phosphate granules from black water}

Recovery of phosphorus from wastewater streams has been widely and extensively investigated in the last 18 years (Desmidt et al., 2015; Driver et al., 1999; Koppelaar and Weikard, 2013; Mayer et al., 2016; Muster et al., 2013; Nättorp et al., 2017). Mayer et al. (2016) discussed the total value of phosphorus recovery, including not only the value of the recovered $\mathrm{P}$ but also secondary revenue streams (energy, nitrogen, and water) and ecological advantages, such as sustainable use of resources and reduction of pollution. Considering this perspective, the total value obtained by $\mathrm{CaP}$ bio granulation process is more than the recovered $\mathrm{CaP}$ granules. Produced $\mathrm{CH}_{4}$ (energy), avoided energy use for aeration, and production of drinking water, saved by vacuum collection, should also be considered. 
Currently, sources of wasted $\mathrm{P}$ are mainly animal manure and sewage, including domestic and industrial wastewater (Desmidt et al., 2015). Regarding animal manure, the Netherlands have an excess of manure production when considering the $\mathrm{P}$ demand and supply, forcing overapplication of $\mathrm{P}$ in farmland, manure incineration, and costly transport of raw manure to other countries. Although there are recovery processes applied for animal manure at full scale, the data on operational costs and production output indicate low financial feasibility (Desmidt et al., 2015). Thus, an economically viable P recovery technology is necessary to extract the excess of $\mathrm{P}$ in manure and to sufficiently concentrate $\mathrm{P}$, enabling its transport from regions with surplus (e.g., The Netherlands, Belgium, and Portugal) to regions with demand (e.g. Argentina, Chile, and Brazil) (Mayer et al., 2016; Robinson et al., 2011).

$\mathrm{P}$ in sewage is recovered as sewage sludge (SS), sewage sludge ash (SSA), and precipitated struvite and $\mathrm{Ca}_{x}\left(\mathrm{PO}_{4}\right)_{y}$ in most industrialized countries (Nättorp et al., 2017). The heavy metals and Fe contents limit the application of SS and SSA as fertilizer or replacement of P rock in the fertilizer industry (Franz, 2008; Herzel et al., 2016; Schipper et al., 2001). Chemical leaching from SSA is the most economical approach ( 0.65 to $6.78 € \mathrm{~kg}^{-1}$ of $\left.\mathrm{P}\right)$, considering the production capacity ( 1 to $1.4 \mathrm{tP} \mathrm{y}^{-1}$ ) and recovery efficiency (70 to $97 \%$ of the $\mathrm{P}$ in sludge) (Nättorp et al., 2017). Technologies to precipitate struvite from the liquid phase of SS dewatering have low recovery yield (7 to $12 \%$ of the P in sludge), which limits the application (Nättorp et al., 2017). Precipitation of struvite from SS acid leaching has a higher yield ( $\sim 50 \%$ of the P in sludge), but the need of chemicals increase the operational cost $(\sim 10$ $€ \mathrm{~kg}^{-1}$ of P) (Nättorp et al., 2017).

For the $\mathrm{CaP}$ bio granulation process, the separation of feces and urine $(\mathrm{BW})$ at the source is key for the low levels of heavy metals in $\mathrm{CaP}$ granules (Chapter 7). Furthermore, the glowing step $\left(800^{\circ} \mathrm{C}\right)$ enables the complete removal of pathogens, residual micropollutants, and remaining organic matter $(29 \mathrm{wt} \%)$ and further increases the $\mathrm{P}$ content in CaP granules from $10 \mathrm{wt} \%$ (at the current process conditions in Chapter 6) to $15 \mathrm{wt} \%$. Although the production of $\mathrm{CaP}$ granules from $\mathrm{BW}$ is decentralized, the centralization of the glowing process would be more cost-effective, as is currently applied for animal manure and sewage sludge. Co-incineration with other $\mathrm{P}$ sources is possible. 


\subsubsection{Usability of recovered calcium phosphate}

For direct use, $\mathrm{CaP}$ granules should comply with the end-of-waste criteria as described in the Article 6 of the Waste Framework Directive 2008/98/EC (European Parliament and Council, 2008). The methodology for the development of the criteria is specific for each product and considers physical and chemical properties of the recovered product, the market segment, and the environmental impact. Moreover, regulation for marketing of fertilizing products has been recently revised to included recovered inorganic and organic materials from waste streams for application as fertilizing products, which were not included in the former version (EC No 2003/2003) (European Commission, 2016). In the revised regulation, materials are divided by component material categories (CMC), which define the source of the product, and product function categories (PFC), which define the function or application of the product.

In Chapter 7, we showed that $\mathrm{CaP}$ granules complied with Dutch and European regulation for application as fertilizer, according to limits for heavy metals and organic micropollutants (Ehlert et al., 2013; European Commission, 2016). However, the presence and level of pathogens are still a concern regarding the application of $\mathrm{CaP}$ granules. The revised regulation for fertilizing products defines operational temperatures during production of component CMC5 ("Other digestate than energy crop digestate"), where raw CaP granules are included, to ensure the safe removal of pathogens (European Commission, 2016). Thermophilic $\left(55^{\circ} \mathrm{C}\right)$ treatment with an HRT of 20 days is one of the options. Another option is the mesophilic $\left(37^{\circ} \mathrm{C}\right.$ to $\left.40^{\circ} \mathrm{C}\right)$ or thermophilic treatment including a pasteurization process at $70^{\circ} \mathrm{C}$ for at least $1 \mathrm{~h}$. Hyperthermophilic $\left(70^{\circ} \mathrm{C}\right)$ anaerobic treatment of BW with an HRT longer than $1 \mathrm{~h}$ for production of $\mathrm{CaP}$ granules is also a possibility, and it is possible by a reduction in the tap water used for toilet flushing as aforementioned. The $\mathrm{CaP}$ bio granulation process was developed and studied at $25^{\circ} \mathrm{C}$, indicating that for recognizing raw $\mathrm{CaP}$ granules as a component $\mathrm{CMC5}$, the temperature conditions should be adapted according to the regulation. The removal of organic material from the $\mathrm{CaP}$ granules during glowing increased the $\mathrm{P}$ content from 10 to $15 \mathrm{wt} \%\left(34 \mathrm{Wt} \% \mathrm{P}_{2} \mathrm{O}_{5}\right.$ ), which is comparable to high-grade $\mathrm{P}$ rock (Abouzeid, 2008), enabling application without organic matter and $\mathrm{CaCO}_{3}$, which is decomposed above $800^{\circ} \mathrm{C}$.

When the anaerobic digestion of BW complies with the temperature requirements, raw $\mathrm{CaP}$ granules could be used as solid $\mathrm{P}$ rich organic fertilizer (function PFC1 AI) and as inorganic macronutrient fertilizer (function PFC1 CI), when glowed. Then, considering the 
reuse options, we assess two possible applications for CaP granules: (1) as direct fertilizer for organic farming and (2) as replacement of P rock in the fertilizer industry.

\subsubsection{Organic farming}

Organic farming represents $1 \%$ of the worldwide agricultural area, but it is rapidly growing (Seufert et al., 2017). Regarding fertilization, the regulation limits the application of artificial or chemically produced fertilizers, enforcing the use of natural fertilizers, such as animal manure and mineral fertilizers (Sajadian et al., 2017; Seufert et al., 2017). For instance, the application of TSP produced from $\mathrm{P}$ rock is prohibited, but $\mathrm{P}$ rock can be directly used as mineral fertilizer. However, the presence of heavy metals and radioactive compounds in $\mathrm{P}$ rock raises concerns for health security (Kratz et al., 2016). Therefore, $\mathrm{CaP}$ granules have a market potential as an organic $\mathrm{P}$ rich fertilizer in organic farming. Moreover, the decentralized production of $\mathrm{CaP}$ granules from $\mathrm{BW}$ is in line with the organic farming policy for local recycling of nutrients (circular economy), due to the shorter distance between communities and agricultural fields when compared with $P$ rock reserves (Seufert et al., 2017).

\subsubsection{2. $P$ fertilizer industry}

Triple superphosphate $\left(\mathrm{Ca}\left(\mathrm{H}_{2} \mathrm{PO}_{4}\right)_{2}\right.$, TSP $)$ and ammonium or diammonium phosphate (MAP and DAP, respectively) are the most produced P compounds from the wet and thermal treatment of P rock in the fertilizer industry (Desmidt et al., 2015; Driver et al., 1999). Processing limitations of $\mathrm{P}$ rock are related to contaminants, such as $\mathrm{Fe}, \mathrm{Cu}$, volatile metals $(\mathrm{Cd}, \mathrm{Pb}$, and $\mathrm{Zn})$, carbonates, organic material, and ammonium (Schipper et al., 2001). Additionally, the minimum viable $\mathrm{P}$ content for processing is $25 \mathrm{wt} \%$ of $\mathrm{P}_{2} \mathrm{O}_{5}$ (Schipper et al., 2001). The use of SS and SSA is then limited by the excess of $\mathrm{Fe}, \mathrm{Cu}$, and $\mathrm{Zn}$ and low $\mathrm{P}$ content. Production of $\mathrm{Ca}_{x}\left(\mathrm{PO}_{4}\right)_{y}$ by lime addition after SSA leaching can reduce the $\mathrm{Fe}, \mathrm{Cu}$, and $\mathrm{Zn}$ contents and increase the $\mathrm{P}$ content, enabling its use as a replacement of $\mathrm{P}$ rock (Franz, 2008). For $\mathrm{CaP}$ granules, glowing at $800^{\circ} \mathrm{C}$ is required for removal of carbonates and organic material (Abouzeid, 2008). However, the concentration of both fractions could be reduced by optimization of the $\mathrm{CaP}$ bio granulation process: (1) washing of granules (mixing) to reduce organic content and (2) regulation of bulk $\mathrm{pH}$ to minimize co-precipitation of $\mathrm{CaCO}_{3}$. The use of glowed $\mathrm{CaP}$ granules or a mixture of glowed $\mathrm{CaP}$ granules and $\mathrm{P}$ rock in the thermal route for TSP production is a potential option. Heavy metal and $\mathrm{Fe}$ contents in $\mathrm{CaP}$ granules are below the maximum limits, and the $\mathrm{P}$ content ( $34 \mathrm{wt} \%$ of $\mathrm{P}_{2} \mathrm{O}_{5}$ ) is above the minimum requirement for the fertilizer industry (Chapter 7). Water-soluble phosphate fertilizers are logistically favored over solid phosphate fertilizers in agriculture because it is easier to apply a liquid than a solid fertilizer. 


\subsubsection{Capacity of CaP granules production from black water versus $P$ fertilizer demand}

The use of CaP granules as fertilizer in organic farming and as a raw material in the fertilizer industry is possible, but the production capacity versus demand dictates the overall feasibility and impact on the $\mathrm{P}$ cycle.

The production capacity of CaP granules from BW is dependent on the community size (p.e.) at the collection. For example, a community of five residential buildings with a total of 2000 p.e. located in an industrialized country requires an agricultural $\mathrm{P}$ rock input of $4.1 \mathrm{tP}$ $\mathrm{y}^{-1}$, but only $32 \%$ of $\mathrm{P}$ added from $\mathrm{P}$ rock ends up at the fork (Figure 8.4). In developing countries, the $\mathrm{P}$ balance is significantly more efficient due to the dietary habits (vegetarianbased diet) (Cordell et al., 2009). Considering the aforementioned P recovery as CaP granules $\left(0.25 \mathrm{kgP}\right.$ p.e. $\left.{ }^{-1} \mathrm{y}^{-1}\right)$ from a community (2000 p.e.) in The Netherlands, the potential production capacity for this scale of SSS treatment plant is $0.5 \mathrm{tP} \mathrm{y}^{-1}$.

In total, $45 \mathrm{kgP} \mathrm{ha}^{-1} \mathrm{y}^{-1}$ was used in the Netherlands in 2004 , from which $27 \%$ was imported as mineral fertilizer. In 2010, the annual regulatory limit for the use of $\mathrm{P}$ in arable (crop) land and grassland in The Netherlands was 37 and $44 \mathrm{kgP} \mathrm{ha}^{-1} \mathrm{y}^{-1}$, respectively (Smit et al., 2010b). The average input in EU15 in 2009 was $24 \mathrm{kgP} \mathrm{ha}^{-1} \mathrm{y}^{-1}$ from which $9 \mathrm{kgP} \mathrm{ha}^{-1} \mathrm{y}^{-1}$ (38\%) was added as P rock (Schröder et al., 2010). Thus, the community (2000 p.e.) could supply $\mathrm{P}$ as $\mathrm{CaP}$ granules for only 55 hectares of the 458 hectares of agricultural land required for food production, considering the standard $\mathrm{P}$ input. Thus, the production of $\mathrm{CaP}$ granules from BW could replace 12\% of the P rock input per capita in Europe (Cordell et al., 2009).

For dietary standards in industrialized countries $\left(2.1 \mathrm{kgP}\right.$ p.e. $\left.{ }^{-1} \mathrm{y}^{-1}\right)$, the agricultural land required for 2000 p.e. is 458 hectares $\left(9 \mathrm{kgP} \mathrm{ha}^{-1} \mathrm{y}^{-1}\right)$. The unsustainable use of $\mathrm{P}$ (Figure 8.4) leads to low efficiency of $P$ extraction from $P$ rock (32\%), resulting in loss of $P$ to the environment and accumulation of $\mathrm{P}$ in farmland (68\%). Thus, at balanced $\mathrm{P}$ fertilization $\mathrm{CaP}$ can contribute to $38.5 \%$ of the P needed. As reported by Cordell et al. (2011), the solution for $\mathrm{P}$ scarcity cannot be solved by one technology. A holistic approach, including societal and economic aspects, and improved management and efficient use of $\mathrm{P}$ are needed. Regarding the energy balance of the SSS treatment plant, the heat and electricity produced are sufficient to cover the energetic demands of the treatment of BW and the BW collection and transport (Graaff et al., 2011a). 


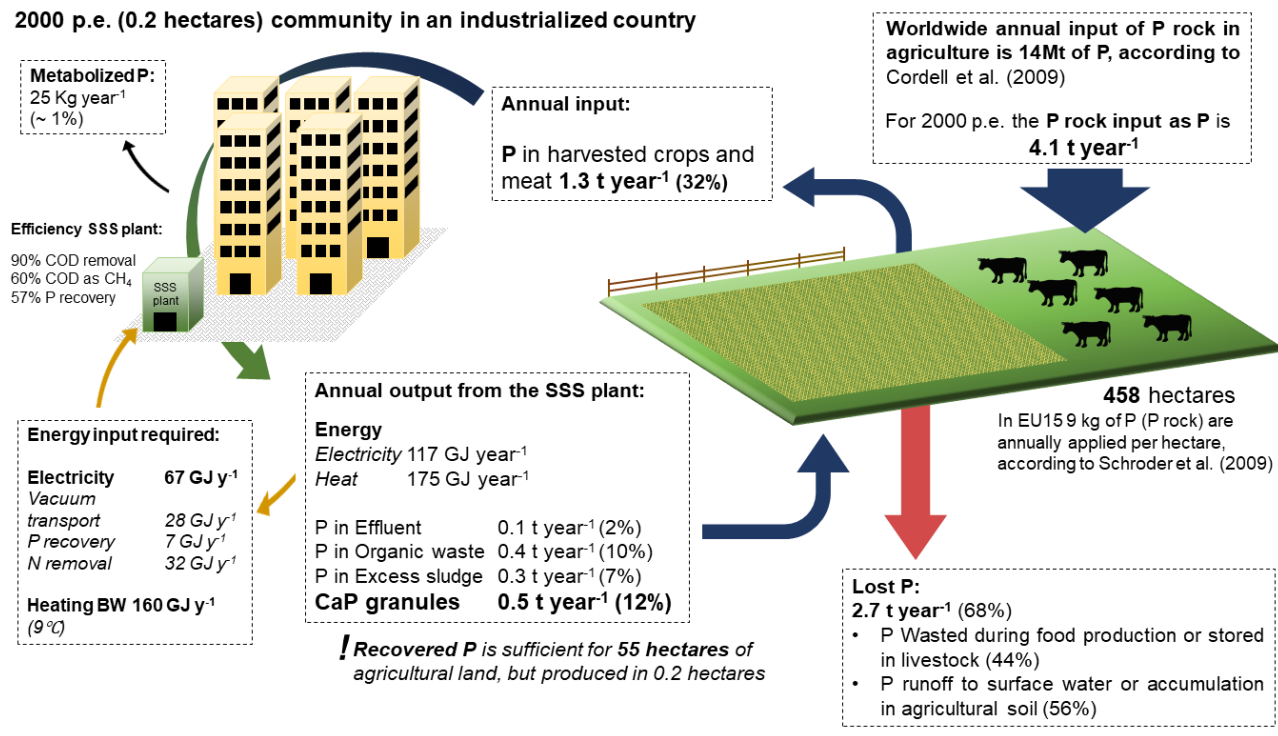

Assumptions:

- Methanization during anaerobic digestion $0.6 \mathrm{gCOD}-\mathrm{CH}_{4} \mathrm{~g}^{-1} \mathrm{COD}-\mathrm{BW}$;

- Energetic efficiency for biogas treatment and $\mathrm{CH}_{4}$ use is $35.6 \mathrm{MJ} \mathrm{m}^{-3}$

( $85 \%$, from which $60 \%$ is heat and $40 \%$ is electricity);

- Metabolized P is $5 \%$ of $P$ eaten:

- $2 / 3$ of the post-harvested food is eaten (Cordell et al. 2009 ).

- $3 / 4$ of the harvested crops are is eaten (Cordell et al. 2009);

Figure 8.4 Simulation of phosphorus flows for a community of 2000 p.e. in an industrialized country, including the SSS concept with $\mathrm{CaP}$ bio granulation process and the energy balance for the SSS treatment plan.

\subsection{Wastewater streams suited for CaP bio granulation}

In this thesis, we mostly explored $\mathrm{CaP}$ bio granulation process during anaerobic treatment of source separated BW. However, in Chapter 5, we used glucose as sole carbon source combined with simulated chemical matrix of $\mathrm{BW}$ at controlled bulk $\mathrm{pH}$. We found that carbon source and bulk $\mathrm{pH}$ are key factors for $\mathrm{CaP}$ bio granulation process during anaerobic treatment. Bulk pH between 7.0 and 7.5 and sufficient production of extracellular biopolymers (EPS) for formation of the outer biofilm (EPS + microorganisms) characteristic of CaP granules are required conditions. The biofilm is essential to develop an increasing $\mathrm{pH}$ gradient, which favors $\mathrm{Ca}_{\mathrm{x}}\left(\mathrm{PO}_{4}\right)_{\mathrm{y}}$ enrichment in the granule over bulk precipitation (Chapter 4 and 5). Other wastewater types which could be used for $\mathrm{CaP}$ bio granulation, considering the potential production of EPS and P the concentration, are shown in Table 8.1.

The contact time and extent between biomass and inorganic particles and the decay rate of internal organic matter dictate the granule maturation time. For the implementation of the $\mathrm{CaP}$ bio granulation process, the form and concentration of volatile suspended solids (VSS) 
in the influent stream and the degradation rate of organic solids are aspects to consider. For instance, the average VSS concentration in $\mathrm{BW}$ was $3.4 \mathrm{gVSS} \mathrm{L}^{-1}\left(\mathrm{VSS} / \mathrm{P}_{\text {Total }}\right.$ mass ratio in BW was $20 \pm 12$ ), and feces (particulate material) are mostly composed of proteins (2 to 25 $\mathrm{wt} \%$ ), carbohydrates (25 wt \%), fats (8 to $16 \mathrm{wt} \%$ ), and bacterial biomass (25 to $50 \mathrm{wt} \%$ ) (Penn et al., 2018). The hydrolysis of solids for BW is higher when compared with wastewater types containing higher concentration of lignocellulosic crop residues than $\mathrm{BW}$, such as cattle manure or paper wastewater (Vavilin et al., 2008). A reduction in the VSS degradation rate could be detrimental for initiation of CaP bio granulation (initial nuclei of EPS + microorganisms $+\mathrm{Ca}_{\mathrm{x}}\left(\mathrm{PO}_{4}\right)_{\mathrm{y}}$ fine particles) and further granule growth (agglomeration of $\mathrm{Ca}_{\mathrm{x}}\left(\mathrm{PO}_{4}\right)_{\mathrm{y}}$ particles in the granule core). Liquid (or filtered) cattle manure has lower concentration of lignocellulosic solids, and therefore, would be more suitable for $\mathrm{CaP}$ bio granulation than raw cattle manure. For brewery wastewater, the low $\mathrm{pH}$ at collection can become a problem for implementation of $\mathrm{CaP}$ bio granulation process, requiring additional chemicals to increase the pH (Arantes et al., 2017; Batstone et al., 2004; Shao et al., 2008). $\mathrm{NaHCO}_{3}$ and $\mathrm{NaOH}$ are used to increase the $\mathrm{pH}$ to neutral values before anaerobic digestion of brewery wastewater (Batstone et al., 2004; Shao et al., 2008). Brewery wastewater is often treated using UASB technology, which creates the opportunity for retrofitting the reactor, enabling implementation of $\mathrm{CaP}$ bio granulation process at reduced cost. In summary, bulk $\mathrm{pH}$, EPS yield, VSS composition and concentration, and $\mathrm{P}$ and Ca concentrations are important aspects to consider for implementation of $\mathrm{CaP}$ bio granulation process during anaerobic treatment of other waste streams.

Table 8.1 List of wastewater streams for potential application of CaP bio granulation process.

\begin{tabular}{lccccc}
\hline Wastewater source & $\begin{array}{c}\text { COD }_{\text {Total }} \\
\mathbf{g ~ L}^{-1}\end{array}$ & $\begin{array}{c}\text { VSS } \\
\mathbf{g ~ L}^{-1}\end{array}$ & $\begin{array}{c}\text { Total P } \\
\mathbf{g ~ L}^{-1}\end{array}$ & $\mathbf{p H}$ & Reference \\
\hline Liquid Cattle Manure & $14 \pm 2$ & $8 \pm 1$ & $0.08 \pm 0.03$ & $7.2 \pm 0.2$ & (Rico et al., 2011) \\
Brewery wastewater & $22-32$ & $0.3-5$ & $0.14-0.22$ & $3-4$ & (Shao et al., 2008) \\
Potato starch processing & 26 & 20 & 0.96 & 6 & (Antwi et al., 2017) \\
\hline
\end{tabular}

\subsection{Prospects for SSS with CaP bio granulation}

Combined transport and centralized treatment of domestic wastewater is the present standard for global sanitation. Considering that implementation of SSS within existing infrastructure requires significant hardware changes, the marketplace for SSS is for construction of new communities and re-construction (renovation) of existing neighborhoods and sewers. 
In the Netherlands, the current perception of SSS (specifically separation of BW and gray water) and its benefits are positive, considering the value-belief-norm theory applied at 338 Dutch citizens (Poortvliet et al., 2018). However, the economic viability of SSS widespread is the main challenge (Roefs et al., 2017). Considering the CAPEX and OPEX of both scenarios (centralized and decentralized), SSS is only $2 \%$ more expensive, due to the more complex sewer and pumping systems. However, when cost reduction aspects are considering, such as reduction in water use for toilet flushing (from $6 \mathrm{~L}$ per flush in conventional toilets to $0.25 \mathrm{~L}$ per flush with vacuum collection), future decrease of CAPEX for vacuum systems and SSS equipment, and revenue streams from recycled resources (e.g., CaP granules, $\mathrm{NH}_{3}$, and $\mathrm{CH}_{4}$ ), $\mathrm{SSS}$ is more cost effective than the conventional centralized sewage treatment (Graaf and Hell, 2014; Roefs et al., 2017). Results are based on extrapolation scenarios for implementation of SSS to 1200 p.e. districts and implementation of centralized sanitation to 57000 p.e., including sewer systems between districts and centralized treatment plant. Similarly, Thibodeau et al. (2011) reported that the annual cost per inhabitant of SSS (5000 p.e.) with low water use ( $0.25 \mathrm{~L}$ per flush) is only $14 \%$ higher than centralized sanitation (50000 p.e.); including costs for storage and distribution of nutrients in farmland, which are assumed to be 9 times higher for SSS (54 USD p.e. ${ }^{-1} \mathrm{y}^{-1}$ ) than centralized sanitation (6 USD p.e. $\left.{ }^{-1} \mathrm{y}^{-1}\right)$ because digested sludge from SSS is transported wet $\left(5.2 \mathrm{~L} \mathrm{p.e.} .^{-1} \mathrm{~d}^{-1}\right.$, with $\sim 60$ gTS $\left.\mathrm{L}^{-1}\right)$ and from centralized sanitation is transported dry $\left(0.3 \mathrm{~L} \mathrm{p.e.}{ }^{-1} \mathrm{~d}^{-1}\right)$. Therefore, the further valorization of resources (water, nutrients, and energy) will benefit SSS over centralized sanitation.

The CaP bio granulation process enables a higher $\mathrm{P}$ recovery efficiency than the current option of struvite precipitation and provides an interesting product for agriculture, considering the current demand for fertilizers with different ratios of $\mathrm{N}, \mathrm{P}$, and $\mathrm{K}$ to match the crop growth requirements. In $\mathrm{CaP}$ granules, the only macronutrient present is $\mathrm{P}$, enabling flexibility for production of efficient fertilizers. The use of more efficient fertilizers in agriculture prevents overuse of scarce nutrients and reduces environmental pollution by runoff of nutrients. Thus, the optimization of sanitation and resource recovery from waste is crucial for life on earth. 


\section{Summary}

Anaerobic calcium phosphate bio granulation was originally observed by Tervahauta et al. (2014c) during treatment of source separated black water. However, the required conditions and mechanism behind the granulation were unknown, which limited the phosphorus recovery efficiency to only $2 \%$. Therefore, in this thesis, the anaerobic calcium phosphate bio granulation, to enhance the process feasibility for simultaneous recovery of phosphorus and methane in a single bioreactor, was extensively investigated.

In Chapter 2, the results for the reproduction of the calcium phosphate bio granulation during anaerobic treatment of black water using an Upflow Anaerobic Sludge Blanket (UASB) reactor are presented. An increased bicarbonate concentration in raw black water reduces the ionic activity of soluble calcium significantly, decreasing the phosphorus accumulation in the UASB reactor. Thus, a low concentration of soluble calcium limits phosphorus accumulation, and consequently, affects calcium phosphate bio granulation. Without calcium addition, $5 \%$ of the total influent phosphorus was found as calcium phosphate granules in the reactor, after 260 days of operation. Simultaneously, $65 \%$ of the organic loading in black water was converted to methane at a process temperature of $25^{\circ} \mathrm{C}$.

Chapter 3 shows that addition of extra calcium increases the accumulation of phosphorus in the reactor from $51 \%$ to $89 \%$ and also stimulates the formation and growth of calcium phosphate granules. Moreover, calcium addition increases the phosphorus content in calcium phosphate granules (> $0.4 \mathrm{~mm}$ diameter) from 3.7 to $5.6 \mathrm{wt} \%$. The phosphorus recovery efficiency as calcium phosphate granules increased to $31 \%$, by dosing $250 \mathrm{mgCa}^{2+}$ $\mathrm{L}^{-1}$ of black water.

A characteristic outer biofilm around the calcium phosphate core was consistently observed, as presented in Chapter 2 and 3. Thus, the role of the outer biofilm on calcium phosphate bio granulation was described in Chapter 4. An increasing $\mathrm{pH}$ gradient from the edge (7.4) to the granule core (7.9) was measured. The $\mathrm{pH}$ gradient enhances internal supersaturation for calcium phosphate phases, creating conditions for preferable calcium phosphate enrichment of the granule over bulk calcium phosphate precipitation. The $\mathrm{pH}$ profile can be explained by measured bio-conversion of acetate and $\mathrm{H}_{2}, \mathrm{HCO}_{3}{ }^{-}$, and $\mathrm{H}^{+}$into $\mathrm{CH}_{4}$ in the outer biofilm and eventually stripping of biogas $\left(\mathrm{CO}_{2}\right.$ and $\left.\mathrm{CH}_{4}\right)$ from the granule. Consequently, $\mathrm{H}^{+}$released from aqueous phosphate species during $\mathrm{Ca}_{\mathrm{x}}\left(\mathrm{PO}_{4}\right)_{\mathrm{y}}$ crystallization are internally buffered, stimulating further calcium phosphate precipitation. 
In Chapter 5 results that demonstrate that the carbon source and bulk $\mathrm{pH}$ are crucial parameters for formation and growth of calcium phosphate granules in a UASB reactor are presented. Anaerobic calcium phosphate bio granulation was achieved using glucose as the sole carbon source while keeping the bulk $\mathrm{pH}$ at 7.5. Volatile fatty acids did not yield calcium phosphate granules, and higher bulk pH (8.0 to 8.2) enhanced calcium phosphate precipitation in the bulk of the reactor. Produced extracellular biopolymers stimulated agglomeration of biomass and inorganic calcium phosphate particles, promoting the formation of granules at relatively low upflow velocity $\left(<1 \mathrm{~cm} \mathrm{~h}^{-1}\right)$.

In Chapter 6, a novel reactor design, to enhance the phosphorus content in the calcium phosphate granules and the concentration of granules at the harvesting location, is presented. The novel reactor consists of a combination of UASB and gas-lift technologies. The injection of $\mathrm{N}_{2}$ at the bottom of a concentric draft tube creates an internal loop with a concentric upflow velocity $\left(18 \mathrm{~m} \mathrm{~h}^{-1}\right)$, which lifts lighter particles from the bottom of the sludge bed. Consequently, at steady state, the bottom of the reactor became more compact ( $73 \mathrm{~g}$ of total solids $\mathrm{L}^{-1}$ of sludge), while at the top of the reactor a lighter sludge bed was obtained ( $31 \mathrm{~g}$ of total solids $\mathrm{L}^{-1}$ of sludge). Moreover, the phosphorus concentration at the bottom of the reactor (harvesting location) increased from $3.0 \mathrm{~g} \mathrm{~L}^{-1}$ in a conventional UASB reactor with calcium addition to $4.6 \mathrm{~g} \mathrm{~L}^{-1}$ in the novel reactor. Similarly, the phosphorus content in the granules increased from $6.7 \mathrm{wt} \%$ to $7.8 \mathrm{wt} \%$. The higher shear obtained by the gas recirculation increases the phosphorus content by reducing the thickness of the outer biofilm, and consequently, decreases the organic content in calcium phosphate granules.

Chapter 7 presents the results of the characterization of calcium phosphate granules, harvested in the novel reactor and subsequently fluidized at an upflow velocity of $76 \mathrm{~m} \mathrm{~h}^{-1}$. The calcium phosphate granules were characterized to study their potential use as replacement for phosphate rock. The higher shear applied, increased the phosphorus content of the granules to $10 \mathrm{wt} \%$ (or $23 \mathrm{wt} \% \mathrm{P}_{2} \mathrm{O}_{5}$ ), from which $35 \%$ was dissolved within $5 \mathrm{~min}$ in citric acid and $85 \%$ in $\mathrm{H}_{2} \mathrm{SO}_{4}$. Heavy metals $(\mathrm{Cu}, \mathrm{Zn}, \mathrm{Cr}, \mathrm{Ni}, \mathrm{Cd}, \mathrm{As}$, and $\mathrm{Pb}$ ) and organic micropollutants in calcium phosphate granules are below the Dutch and European regulatory limits for application as a direct fertilizer, but pathogens in raw granules are a concern. Therefore, calcium phosphate granules were glowed at $550^{\circ} \mathrm{C}$ to remove pathogens and the remaining organic content (29 wt\%), increasing the phosphorus content to $15 \mathrm{wt} \%$ (or $34 \mathrm{wt} \% \mathrm{P}_{2} \mathrm{O}_{5}$ ). The glowing process enables the direct substitution of phosphate rock by calcium phosphate granules in the phosphate industry for the production of water-soluble phosphate. 


\section{References}

A

Abouzeid, A.Z.M., 2008. Physical and thermal treatment of phosphate ores - An overview. Int. J. Miner. Process. 85, 59-84.

Abu-Ghunmi, D., Abu-Ghunmi, L., Kayal, B., Bino, A., 2016. Circular economy and the opportunity cost of not "closing the loop" of water industry: The case of Jordan. J. Clean. Prod. 131, 228-236.

Ahmadi-Pirlou, M., Ebrahimi-Nik, M., Khojastehpour, M., Ebrahimi, S.H., 2017. Mesophilic co-digestion of municipal solid waste and sewage sludge: Effect of mixing ratio, total solids, and alkaline pretreatment. Int. Biodeterior. Biodegrad. 125, 97-104.

Ahn, J.H., Do, T.H., Kim, S.D., Hwang, S., 2006. The effect of calcium on the anaerobic digestion treating swine wastewater. Biochem. Eng. J. 30, 33-38.

Alexander, P., Rounsevell, M.D.A., Dislich, C., Dodson, J.R., Engström, K., Moran, D., 2015. Drivers for global agricultural land use change: The nexus of diet, population, yield and bioenergy. Glob. Environ. Chang. 35, 138-147.

Algapani, D.E., Qiao, W., Su, M., di Pumpo, F., Wandera, S.M., Adani, F., Dong, R., 2016. Bio-hydrolysis and bio-hydrogen production from food waste by thermophilic and hyperthermophilic anaerobic process. Bioresour. Technol. 216, 768-777.

Alvarino, T., Suarez, S., Lema, J., Omil, F., 2018. Understanding the sorption and biotransformation of organic micropollutants in innovative biological wastewater treatment technologies. Sci. Total Environ. 615, 297-306.

Amir, S., Hafidi, M., Merlina, G., Revel, J.C., 2005. Sequential extraction of heavy metals during composting of sewage sludge. Chemosphere 59, 801-810.

Angelidaki, I., Alves, M., Bolzonella, D., Borzacconi, L., Campos, L., Guwy, A., Jenicek, P., Kalyuzhnyi, S. V., Lier, J.B. Van, 2007. Anaerobic Biodegradation, Activity and Inhibition (ABAI) Task Group Meeting 9th to 10th October 2006, in Prague. Kgs. Lyngby.

Antwi, P., Li, J., Opoku Boadi, P., Meng, J., Shi, E., Xue, C., Zhang, Y., Ayivi, F., 2017. Functional bacterial and archaeal diversity revealed by $16 \mathrm{~S}$ rRNA gene pyrosequencing during potato starch processing wastewater treatment in an UASB. Bioresour. Technol. 235, 348-357.

Arantes, M.K., Alves, H.J., Sequinel, R., da Silva, E.A., 2017. Treatment of brewery wastewater and its use for biological production of methane and hydrogen. Int. J. Hydrogen Energy 42, 26243-26256.

Arne Alphenaar, P., Sleyster, R., De Reuver, P., Ligthart, G.J., Lettinga, G., 1993. Phosphorus requirement in high-rate anaerobic wastewater treatment. Water Res. 27, 749-756.

Ashley, K., Cordell, D., Mavinic, D., 2011. A brief history of phosphorus: From the philosopher's stone to nutrient recovery and reuse. Chemosphere 84, 737-746.

Avery, L.M., Anchang, K.Y., Tumwesige, V., Strachan, N., Goude, P.J., 2014. Potential for Pathogen reduction in anaerobic digestion and biogas generation in Sub-Saharan Africa. Biomass and Bioenergy 70, 112-124. 
Aydin, I., Aydin, F., Saydut, A., Bakirdere, E.G., Hamamci, C., 2010. Hazardous metal geochemistry of sedimentary phosphate rock used for fertilizer (Mazıdag, SE Anatolia, Turkey). Microchem. J. 96, 247-251.

Azoulay, A., Garzon, P., Eisenberg, M.J., 2001. Comparison of the mineral content of tap water and bottled waters. J. Gen. Intern. Med. 16, 168-175.

\section{B}

Bar-Yosef Ofir, P., Govrin-Lippman, R., Garti, N., Füredi-Milhofer, H., 2004. The Influence of Polyelectrolytes on the Formation and Phase Transformation of Amorphous Calcium Phosphate. Cryst. Growth Des. 4, 177-183.

Barbosa Correa, S.M.B., Ruiz, E., Romero, F., 2003. Evolution of operational parameters in a UASB wastewater plant. Water SA 29, 345-352.

Batstone, D.J., 2000. High rate anaerobic treatment of complex wastewater. PhD Thesis, Department of Chemical Engineering, The University of Queensland, Australia.

Batstone, D.J., Hernandez, J.L.A., Schmidt, J.E., 2005. Hydraulics of laboratory and full-scale upflow anaerobic sludge blanket (UASB) reactors. Biotechnol. Bioeng. 91, 387-391.

Batstone, D.J., Keller, J., Angelidaki, I., Kalyuzhnyi, S. V., Pavlostathis, S.G., Rozzi, A., Sanders, W.T., Siegrist, H., Vavilin, V.A., 2002a. The IWA Anaerobic Digestion Model No 1 (ADM1). Water Sci. Technol. 45, 65-73.

Batstone, D.J., Keller, J., Blackall, L.L., 2004. The influence of substrate kinetics on the microbial community structure in granular anaerobic biomass. Water Res. 38, 13901404.

Batstone, D.J., Landelli, J., Saunders, A., Webb, R.I., Blackall, L.L., Keller, J., 2002b. The influence of calcium on granular sludge in a full-scale UASB treating paper mill wastewater. Water Sci. Technol. 45, 187-193.

Bell, L.C., Posner, A.M., Quirk, J.P., 1973. The point of zero charge of hydroxyapatite and fluorapatite in aqueous solutions. J. Colloid Interface Sci. 42, 250-261.

Bertinetti, L., Drouet, C., Combes, C., Rey, C., Tampieri, A., Coluccia, S., Martra, G., 2009. Surface characteristics of nanocrystalline apatites: Effect of $\mathrm{Mg}$ surface enrichment on morphology, surface hydration species, and cationic environments. Langmuir 25, 5647 5654.

Bian, S., Du, L.W., Gao, Y.X., Huang, J., Gou, B. Di, Li, X., Liu, Y., Zhang, T.L., Wang, K., 2012. Crystallization in aggregates of calcium phosphate nanocrystals: A logistic model for kinetics of fractal structure development. Cryst. Growth Des. 12, 3481-3488.

Bollon, J., Benbelkacem, H., Gourdon, R., Buffière, P., 2013. Measurement of diffusion coefficients in dry anaerobic digestion media. Chem. Eng. Sci. 89, 115-119.

Boone, D.R., Xun, L., 1987. Effects of pH, Temperature, and Nutrients on Propionate Degradation by a Methanogenic Enrichment Culture. Appl. Environ. Microbiol. 53, 1589-92.

Bosker, M., Buringh, E., 2017. City seeds: Geography and the origins of the European city system. J. Urban Econ. 98, 139-157. 
Butkovskyi, A., Hernandez Leal, L., Rijnaarts, H.H.M., Zeeman, G., 2015. Fate of pharmaceuticals in full-scale source separated sanitation system. Water Res. 85, 384 392.

Butkovskyi, A., Leal, L.H., Zeeman, G., Rijnaarts, H.H.M., 2017. Micropollutants in source separated wastewater streams and recovered resources of source separated sanitation. Environ. Res. 156, 434-442.

Butkovskyi, A., Ni, G., Hernández Leal, L., Rijnaarts, H.H.M., Zeeman, G., 2016. Mitigation of micropollutants for black water application in agriculture via composting of anaerobic sludge. J. Hazard. Mater. 303, 41-47.

C

Cao, X., Harris, W., 2008. Carbonate and magnesium interactive effect on calcium phosphate precipitation. Environ. Sci. Technol. 42, 436-442.

Cao, X., Sheng, Y., Cao, H., Zhang, Y., 2014. Comparison of Mg2+- and Ca2+-enhancing anaerobic granulation in an expanded granular sludge-bed reactor. Sci. China Chem. 57, 1596-1601.

Caudan, C., Filali, A., Spérandio, M., Girbal-Neuhauser, E., 2014. Multiple EPS interactions involved in the cohesion and structure of aerobic granules. Chemosphere 117, 262-270.

Chaggu, E.J., Sanders, W.T., Lettinga, G., 2007. Demonstration of anaerobic stabilization of black water in accumulation systems under tropical conditions. Bioresour. Technol. 98, 3090-3097.

Chen, Y., Cheng, J.J., Creamer, K.S., 2008. Inhibition of anaerobic digestion process: A review. Bioresour. Technol. 99, 4044-4064.

Clesceri, L.S., Rica, E.W., Baird, R.B., Eaton, A.D., 1998. Standard Methods for the Examination of Water and Wastewater, 20th ed. ed. American Public Health Association, American Water Works Association and Water Environment Federation, Washington D.C.

Cölfen, H., Antonietti, M., 1998. Crystal Design of Calcium Carbonate Microparticles Using Double-Hydrophilic Block Copolymers. Langmuir 14, 582-589.

Combes, C., Rey, C., 2010. Amorphous calcium phosphates: Synthesis, properties and uses in biomaterials. Acta Biomater. 6, 3362-3378.

COMSOL, 2014. CFD Module Model Library Manual. www.comsol.com 1-30.

COMSOL, 2010. CFD Module User's Guide, 4.1. ed. COMSOL AB.

Cooper, J., Lombardi, R., Boardman, D., Carliell-Marquet, C., 2011. The future distribution and production of global phosphate rock reserves. Resour. Conserv. Recycl. 57, 78-86.

Cordell, D., Drangert, J.O., White, S., 2009. The story of phosphorus: Global food security and food for thought. Glob. Environ. Chang. 19, 292-305.

Cordell, D., Rosemarin, A., Schröder, J.J., Smit, A.L., 2011. Towards global phosphorus security: A systems framework for phosphorus recovery and reuse options. Chemosphere 84, 747-758. 
Cunha, J.R., Schott, C., van der Weijden, R.D., Leal, L.H., Zeeman, G., Buisman, C., 2018a. Calcium addition to increase the production of phosphate granules in anaerobic treatment of black water. Water Res. 130, 333-342.

Cunha, J.R., Tervahauta, T., van der Weijden, R.D., Hernández Leal, L., Zeeman, G., Buisman, C.J.N., 2017. Simultaneous recovery of calcium phosphate granules and methane in anaerobic treatment of black water: Effect of bicarbonate and calcium fluctuations. J. Environ. Manage. 1-7.

Cunha, J.R., Tervahauta, T., van der Weijden, R.D., Temmink, H., Leal, L.H., Zeeman, G., Buisman, C.J.N., 2018b. The effect of bioinduced increased $\mathrm{pH}$ on the enrichment of calcium phosphate in granules during anaerobic treatment of black water. Environ. Sci. Technol.

\section{D}

D’Abzac, P., Bordas, F., Joussein, E., Hullebusch, E. Van, Lens, P.N.L., Guibaud, G., 2010. Characterization of the mineral fraction associated to extracellular polymeric substances (EPS) in anaerobic granular sludges. Environ. Sci. Technol. 44, 412-418.

Dai, X., Gai, X., Dong, B., 2014. Rheology evolution of sludge through high-solid anaerobic digestion. Bioresour. Technol. 174, 6-10.

Daigger, G.T., Ph, D., Asce, M., 2007. Wastewater Management in the 21 st Century 133, 671680.

Daintree, L., Biggs, S., 2010. Particle-particle interactions: The link between aggregate properties and rheology. Part. Sci. Technol. 28, 404-425.

Dang, Y., Zhang, R., Wu, S., Liu, Z., Qiu, B., Fang, Y., Sun, D., 2014. Calcium effect on anaerobic biological treatment of fresh leachate with extreme high calcium concentration. Int. Biodeterior. Biodegradation 95, 76-83.

Das, S., Sarkar, S., Chaudhari, S., 2018. Modification of UASB reactor by using CFD simulations for enhanced treatment of municipal sewage. Water Sci. Technol. 77, 766776.

Desmidt, E., Ghyselbrecht, K., Zhang, Y., Pinoy, L., Bruggen, B. Van Der, Verstraete, W., Rabaey, K., Meesschaert, B., 2015. Global Phosphorus Scarcity and Full-Scale PRecovery Techniques: A Review. Crit. Rev. Environ. Sci. Technol. 45, 336-384.

Ding, Z., Bourven, I., Guibaud, G., van Hullebusch, E.D., Panico, A., Pirozzi, F., Esposito, G., 2015. Role of extracellular polymeric substances (EPS) production in bioaggregation: application to wastewater treatment. Appl. Microbiol. Biotechnol. 99, 9883-9905.

Dong, B., Liu, X., Dai, L., Dai, X., 2013. Changes of heavy metal speciation during high-solid anaerobic digestion of sewage sludge. Bioresour. Technol. 131, 152-158.

Drancourt, M., Raoult, D., 2016. Molecular history of plague. Clin. Microbiol. Infect. 22, $911-$ 915.

Driver, J., Lijmbach, D., Steen, I., 1999. Why recover phosphorus for recycling, and how? Environ. Technol. 20, 651-662.

Duarte, A.C., Anderson, G.K., 1982. Inhibition modelling in anaerobic digestion. Water Sci. Technol. 14, 749-763. 
Dutch Water Boards, 2015. Energie- en Grondstoffenfabriek [WWW Document]. URL https://www.efgf.nl/english (accessed 8.6.18).

E

Ehlert, P.A.I., Posthuma, L., Römkens, P.F.A.., Rietra, R.P.J.J., Wintersen, A.M., van Wijnen, H., van Dijk, T.A., van Schöll, L., Groenenberg, J.E., 2013. Appraising Fertilisers : Origins of current regulations and standards for contaminants in fertilisers (Working Document 336). Wageningen.

El-Mamouni, R., Leduc, R., Guiot, S.R., 1998. Influence of synthetic and natural polymers on the anaerobic granulation process. Water Sci. Technol.

El-Mamouni, R., Leduc, R., Guiot, S.R., 1997. Influence of the starting microbial nucleus type on the anaerobic granulation dynamics. Appl. Microbiol. Biotechnol. 47, 189-194.

Elser, J., Bennett, E., 2011. Phosphorus cycle: A broken biogeochemical cycle. Nature 478, 29-31.

Elser, J.J., 2012. Phosphorus: A limiting nutrient for humanity? Curr. Opin. Biotechnol. 23, $833-838$.

Emsley, J., 2000. The Shocking History of Phosphorus: A Biography of the Devil's Element. Macmillan, London.

European Commission, 2017. Recovery and utilization of nutrients for low impact fertilizer (RUN4LIFE) URL https://cordis.europa.eu/project/rcn/210513_en.html (accessed 8.10.18).

European Commission, 2016. Proposal for a Regulation on the making available on the market of CE marked fertilising products and amending regulations (EC) No 1069/2009 and (EC) No 1107/2009 Annexes 1 to 5. Regul. Eur. Parliam. Counc.

European Parliament, 1986. Protection of the Environment, and in particular of the soil, when sewage sludge is used in agriculture (86/278/EEC). Off. J. Eur. Communities 4, 6-12.

European Parliament and Council, 2008. Directive 2008/98/EC of the European Parliament and of the Council of 19 November 2008 on waste and repealing certain directives. Off. J. Eur. Union 3-30.

\section{F}

Fang, H.H.P., Liu, H., 2002. Effect of pH on hydrogen production from glucose by a mixed culture. Bioresour. Technol. 82, 87-93.

Feng, Q.L., Pu, G., Pei, Y., Cui, F.Z., Li, H.D., Kim, T.N., 2000. Polymorph and morphology of calcium carbonate crystals induced by proteins extracted from mollusk shell. J. Cryst. Growth 216, 459-465.

Feng, Y., Behrendt, J., Wendland, C., Otterpohl, R., 2006. Implementation of the IWA anaerobic digestion model No. 1 (ADM1) for simulating digestion of blackwater from vacuum toilets. Water Sci. Technol. 53, 253-263.

Ferguson, J.F., McCarty, P.L., 1971. Effects of Carbonate and Magnesium on Calcium Phosphate Precipitation. Environ. Sci. Technol. 5, 534-540. 
Fosca, M., Komlev, V.S., Fedotov, A.Y., Caminiti, R., Rau, J. V., 2012. Structural study of octacalcium phosphate bone cement conversion in vitro. ACS Appl. Mater. Interfaces 4, 6202-6210.

Franz, M., 2008. Phosphate fertilizer from sewage sludge ash (SSA). Waste Manag. 28, 18091818.

Frølund, B., Palmgren, R., Keiding, K., Nielsen, P.H., 1996. Extraction of extracellular polymers from activated sludge using a cation exchange resin. Water Res. 30, 17491758.

Fukuzaki, S., Nishio, N., Nagai, S., 1990. Kinetics of the methanogenic fermentation of acetate. Appl. Environ. Microbiol. 56, 3158-3163.

\section{G}

Gajjeraman, S., Narayanan, K., Hao, J., Qin, C., George, A., 2007. Matrix macromolecules in hard tissues control the nucleation and hierarchical assembly of hydroxyapatite. J. Biol. Chem. 282, 1193-1204.

Ganidi, N., Tyrrel, S., Cartmell, E., 2009. Anaerobic digestion foaming causes - A review. Bioresour. Technol. 100, 5546-5554.

Garcia-Robledo, E., Ottosen, L.D.M., Voigt, N. V., Kofoed, M.W., Revsbech, N.P., 2016. Micro-scale $\mathrm{H} 2-\mathrm{CO} 2$ dynamics in a hydrogenotrophic methanogenic membrane reactor. Front. Microbiol. 7, 1-10.

Gell, K., Ruijter, F.J. De, Kuntke, P., Graaff, M.S. De, Smit, A.L., 2011. Safety and Effectiveness of Struvite from Black Water and Urine as a Phosphorus Fertilizer. J. Agric. Sci. 3, 67-80.

Ghangrekar, M.M., Asolekar, S.R., Joshi, S.G., 2005. Characteristics of sludge developed under different loading conditions during UASB reactor start-up and granulation. Water Res. 39, 1123-1133.

Gjaltema, A., Tijhuis, L., Loosdrecht, M.C.M. Van, Heijnen, J.J., 1995. Detachment of biomass from suspended nongrowing spherical biofilms in airlift reactors. Biotechnol. Bioeng. 46, 258-269.

Graaf, R. De, Hell, A.J. van, 2014. Nieuwe Sanitatie Noorderhoek, Sneek: Deelonderzoeken. Rapport 48. Amersfoort, The Netherlands.

Graaff, M.S. De, Temmink, H., Zeeman, G., Buisman, C.J.N., 2011a. Energy and phosphorus recovery from black water. Water Sci. Technol. 63, 2759-65.

Graaff, M.S. De, Temmink, H., Zeeman, G., Buisman, C.J.N., 2010. Anaerobic Treatment of Concentrated Black Water in a UASB Reactor at a Short HRT. Water 2, 101-119.

Graaff, M.S. De, Temmink, H., Zeeman, G., Loosdrecht, M.C.M. Van, Buisman, C.J.N., 2011b. Autotrophic nitrogen removal from black water: Calcium addition as a requirement for settleability. Water Res. 45, 63-74.

Graaff, M.S. De, Vieno, N.M., Kujawa-Roeleveld, K., Zeeman, G., Temmink, H., Buisman, C.J.N., 2011c. Fate of hormones and pharmaceuticals during combined anaerobic treatment and nitrogen removal by partial nitritation-anammox in vacuum collected black water. Water Res. 45, 375-383. 


\section{H}

Habraken, W.J.E.M., Tao, J.H., Brylka, L.J., Friedrich, H., Bertinetti, L., Schenk, A.S., Verch, A., Dmitrovic, V., Bomans, P.H.H., Frederik, P.M., Laven, J., Schoot, P. Van Der, Aichmayer, B., With, G. De, DeYoreo, J.J., Sommerdijk, N.A.J.M., 2013. Ionassociation complexes unite classical and non-classical theories for the biomimetic nucleation of calcium phosphate. Nat. Commun. 4.

Halalsheh, M., Koppes, J., Den Elzen, J., Zeeman, G., Fayyad, M., Lettinga, G., 2005. Effect of SRT and temperature on biological conversions and the related scum-forming potential. Water Res. 39, 2475-2482.

He, F.J., MacGregor, G.A., 2008. Beneficial effects of potassium on human health. Physiol. Plant. 133, 725-735.

He, Z., Pagliari, P.H., Waldrip, H.M., 2016. Applied and Environmental Chemistry of Animal Manure: A Review. Pedosphere 26, 779-816.

Herzel, H., Krüger, O., Hermann, L., Adam, C., 2016. Sewage sludge ash - A promising secondary phosphorus source for fertilizer production. Sci. Total Environ. 542, 1136 43.

Horan, N.J., Fletcher, L., Betmal, S.M., Wilks, S.A., Keevil, C.W., 2004. Die-off of enteric bacterial pathogens during mesophilic anaerobic digestion. Water Res. 38, 1113-1120.

Hori, T., Haruta, S., Ueno, Y., Ishii, M., Igarashi, Y., 2006. Dynamic Transition of a Methanogenic Population in Response to the Concentration of Volatile Fatty Acids in a Thermophilic Anaerobic Digester Dynamic Transition of a Methanogenic Population in Response to the Concentration of Volatile Fatty Acids in a The. Appl. Environ. Microbiol. 72, 1623-1630.

Houhou, J., Lartiges, B.S., Montarges-Pelletier, E., Sieliechi, J., Ghanbaja, J., Kohler, A., 2009. Sources, nature, and fate of heavy metal-bearing particles in the sewer system. Sci. Total Environ. 407, 6052-6062.

Hu, X.G., Luo, Y., Zhou, Q.X., Xu, L., 2008. Determination of thirteen antibiotics residues in manure by solid phase extraction and high performance liquid chromatography. Fenxi Huaxue/ Chinese J. Anal. Chem. 36, 1162-1166.

Hulshoff Pol, L.W., Castro Lopes, S.I. De, Lettinga, G., Lens, P.N.L., 2004. Anaerobic sludge granulation. Water Res. 38, 1376-89.

\section{I}

Ismail, S.B., Parra, C.J. de La, Temmink, H., Lier, J.B. Van, 2010. Extracellular polymeric substances (EPS) in upflow anaerobic sludge blanket (UASB) reactors operated under high salinity conditions. Water Res. 44, 1909-1917.

\section{$\mathbf{J}$}

Jarvie, H.P., Neal, C., Withers, P.J.A., 2006. Sewage-effluent phosphorus: A greater risk to river eutrophication than agricultural phosphorus? Sci. Total Environ. 360, 246-253. 
Jia, X., Furumai, H., Kusuda, T., 1993. Formation of extracellular polymer and surface charge of sludge in anaerobic degradation process. Water Sci. Technol. 16, 859-868.

Jones-Lepp, T.L., Stevens, R., 2007. Pharmaceuticals and personal care products in biosolids/sewage sludge: The interface between analytical chemistry and regulation. Anal. Bioanal. Chem. 387, 1173-1183.

\section{$\mathbf{K}$}

Kacprzak, M., Neczaj, E., Fijałkowski, K., Grobelak, A., Grosser, A., Worwag, M., Rorat, A., Brattebo, H., Almås, Å., Singh, B.R., 2017. Sewage sludge disposal strategies for sustainable development. Environ. Res. 156, 39-46.

Kalyuzhnyi, S., Sklyar, V., Epov, A., Arkhipchenko, I., Barboulina, I., Orlova, O., Klapwijk, A., 2002. Combined biological and physico-chemical treatment of filtered pig manure wastewater: Pilot investigations. Water Sci. Technol. 45, 79-87.

Karu, N., Deng, L., Slae, M., Guo, A.C., Sajed, T., Huynh, H., Wine, E., Wishart, D.S., 2018. A review on human fecal metabolomics: Methods, applications and the human fecal metabolome database. Anal. Chim. Acta 1-24.

Kelessidis, A., Stasinakis, A.S., 2012. Comparative study of the methods used for treatment and final disposal of sewage sludge in European countries. Waste Manag. 32, 11861195.

Kobayashi, K., Anada, T., Handa, T., Kanda, N., Yoshinari, M., Takahashi, T., Suzuki, O., 2014. Osteoconductive property of a mechanical mixture of octacalcium phosphate and amorphous calcium phosphate. ACS Appl. Mater. Interfaces 6, 22602-22611.

Kobielska, P.A., Howarth, A.J., Farha, O.K., Nayak, S., 2018. Metal-organic frameworks for heavy metal removal from water. Coord. Chem. Rev. 358, 92-107.

Koppelaar, R.H.E.M., Weikard, H.P., 2013. Assessing phosphate rock depletion and phosphorus recycling options. Glob. Environ. Chang. 23, 1454-1466.

Kornberg, A., Rao, N.N., Ault-Riché, D., 1999. Inorganic polyphosphate: a molecule of many functions. Annu. Rev. Biochem. 68, 89-125.

Kratz, S., Schick, J., Schnug, E., 2016. Trace elements in rock phosphates and P containing mineral and organo-mineral fertilizers sold in Germany. Sci. Total Environ. 542, 1013 1019.

Kujawa-Roeleveld, K., Fernandes, T., Wiryawan, Y., Tawfik, A., Visser, M., Zeeman, G., 2005. Performance of UASB septic tank for treatment of concentrated black water within DESAR concept. Water Sci. Technol. 52, 307-313.

Kujawa-Roeleveld, K., Zeeman, G., 2006. Anaerobic treatment in decentralised and sourceseparation-based sanitation concepts. Rev. Environ. Sci. Biotechnol. 5, 115-139.

Kuntke, P., Sleutels, T.H.J.A., Rodríguez Arredondo, M., Georg, S., Barbosa, S.G., ter Heijne, A., Hamelers, H.V.M., Buisman, C.J.N., 2018. (Bio)electrochemical ammonia recovery: progress and perspectives. Appl. Microbiol. Biotechnol. 102, 3865-3878.

Kwok, W.K., Picioreanu, C., Ong, S.L., Loosdrecht, M.C.M. Van, Ng, W.J., Heijnen, J.J., 1998. Influence of biomass production and detachment forces on biofilm structures in a biofilm airlift suspension reactor. Biotechnol. Bioeng. 58, 400-407. 


\section{L}

Landman, K.A., White, L.R., 1994. Solid/liquid separation of flocculated suspensions. Adv. Colloid Interface Sci. 51, 175-246.

Langerak, E.P.A. Van, Gonzalez-Gil, G., Aelst, A. Van, Lier, J.B. Van, Hamelers, H.V.M., Lettinga, G., 1998. Effects of high calcium concentrations on the development of methanogenic sludge in upflow anaerobic sludge bed (UASB) reactors. Water Res. 32, 1255-1263.

Laspidou, C.S., Rittmann, B.E., 2004. Modeling the development of biofilm density including active bacteria, inert biomass, and extracellular polymeric substances. Water Res. 38, 3349-3361.

Lawrence, E.A., Doherty, D., Dhanda, R., 2018. Function of the nephron and the formation of urine. Anaesth. Intensive Care Med. 19, 249-253.

Lebuf, V., Accoe, F., Elsacker, S. Van, Vaneeckhaute, C., Michels, E., Meers, E., Ghekiere, G., Ryckaert, B., 2013. Inventory, Techniques for nutrient recovery from digestate. Report from the framework of the ARBOR Interreg IVb project, Vlaams Coördinatiecentrum Mestverwerking, Univercity of Ghent and Inagro, Ghent, Belgium.

Lei, Y., Remmers, J.C., Saakes, M., van der Weijden, R., Buisman, C.J.N., 2018. Is there a precipitation sequence in municipal wastewater induced by electrolysis? Environ. Sci. Technol. acs.est.8b02869.

Lens, P., Zeeman, G., Lettinga, G., 2001. Decentralized Sanitation and Reuse: Concepts, Systems and Implementation. IWA Publishing.

Lettinga, G., van Velsen, A.F.M., Hobma, S.W., de Zeeuw, W., Klapwijk, A., 1980. Use of the upflow sludge blanket (USB) reactor concept for biological wastewater treatment, especially for anaerobic treatment. Biotechnol. Bioeng. 22, 699-734.

Li, H., Wen, Y., Cao, A., Huang, J., Zhou, Q., Somasundaran, P., 2012. The influence of additives $(\mathrm{Ca} 2+, \mathrm{Al} 3+$, and $\mathrm{Fe} 3+)$ on the interaction energy and loosely bound extracellular polymeric substances (EPS) of activated sludge and their flocculation mechanisms. Bioresour. Technol. 114, 188-194.

Li, X., Zhu, W., Wu, Y., Wang, C., Zheng, J., Xu, K., Li, J., 2015. Recovery of potassium from landfill leachate concentrates using a combination of cation-exchange membrane electrolysis and magnesium potassium phosphate crystallization. Sep. Purif. Technol. 144, 1-7.

Li, X.Y., Yang, S.F., 2007. Influence of loosely bound extracellular polymeric substances (EPS) on the flocculation, sedimentation and dewaterability of activated sludge. Water Res. 41, 1022-1030.

Liao, B.Q., Allen, D.G., Droppo, I.G., Leppard, G.G., Liss, S.N., 2001. Surface Properties of Sludge and Their Role in Bioflocculation and Settleability. Water Res. 35, 339-350.

Lier, J.B. Van, Mahmoud, N., Zeeman, G., 2008. Anaerobic Wastewater Treatment, in: Henze, M., van Loosdrecht, M.C.M., Ekama, G.A., Brdjanovic, D. (Eds.), Biological Wastewater Treatment: Principles, Modelling and Design. IWA Publishing, London, pp. 401-442.

Liu, X.M., Sheng, G.P., Luo, H.W., Zhang, F., Yuan, S.J., Xu, J., Zeng, R.J., Wu, J.G., Yu, H.Q., 2010. Contribution of extracellular polymeric substances (EPS) to the sludge aggregation. Environ. Sci. Technol. 44, 4355-4360. 
Liu, Y.-Q., Liu, Y., Tay, J.-H., 2004. The effects of extracellular polymeric substances on the formation and stability of biogranules. Appl. Microbiol. Biotechnol. 65, 143-8.

Liu, Y., Tay, J.-H., 2004. State of the art of biogranulation technology for wastewater treatment. Biotechnol. Adv. 22, 533-563.

Liu, Y., Villalba, G., Ayres, R.U., Schroder, H., 2008. Global phosphorus flows and environmental impacts from a consumption perspective. J. Ind. Ecol. 12, 229-247.

Liu, Y., Xu, H.L., Show, K.Y., Tay, J.-H., 2002. Anaerobic granulation technology for wastewater treatment. World J. Microbiol. Biotechnol. 18, 99-113.

Liu, Y.H., He, Y.L., Yang, S.C., Li, Y.Z., 2006. The settling characteristics and mean settling velocity of granular sludge in upflow anaerobic sludge blanket (UASB)-like reactors. Biotechnol. Lett. 28, 1673-1678.

Lofrano, G., Brown, J., 2010. Wastewater management through the ages: A history of mankind. Sci. Total Environ. 408, 5254-5264.

\section{M}

Mahmoud, N., Zeeman, G., Gijzen, H.J., Lettinga, G., 2003. Solids removal in upflow anaerobic reactors, a review. Bioresour. Technol. 90, 1-9.

Malmborg, J., Magnér, J., 2015. Pharmaceutical residues in sewage sludge: Effect of sanitization and anaerobic digestion. J. Environ. Manage. 153, 1-10.

Mañas, A., Pocquet, M., Biscans, B., Spérandio, M., 2012. Parameters influencing calcium phosphate precipitation in granular sludge sequencing batch reactor. Chem. Eng. Sci. 77, $165-175$.

Mañas, A., Spérandio, M., Decker, F., Biscans, B., 2012. Location and chemical composition of microbially induced phosphorus precipitates in anaerobic and aerobic granular sludge. Environ. Technol. (United Kingdom) 33, 2195-2209.

Mayer, B.K., Baker, L.A., Boyer, T.H., Drechsel, P., Gifford, M., Hanjra, M.A., Parameswaran, P., Stoltzfus, J., Westerhoff, P., Rittmann, B.E., 2016. Total Value of Phosphorus Recovery. Environ. Sci. Technol. 50, 6606-6620.

McClellan, K., Halden, R.U., 2010. Pharmaceuticals and personal care products in archived U.S. biosolids from the 2001 EPA national sewage sludge survey. Water Res. 44, 658668.

McGrath, J.M., Spargo, J., Penn, C.J., 2014. Soil Fertility and Plant Nutrition. Encycl. Agric. Food Syst. 5, 166-184.

Meena, V.S., Maurya, B.R., Verma, J.P., Meena, R.S., 2016. Potassium solubilizing microorganisms for sustainable agriculture. Potassium Solubilizing Microorg. Sustain. Agric. 1-331.

Mehta, C.M., Khunjar, W.O., Nguyen, V., Tait, S., Batstone, D.J., 2015. Technologies to Recover Nutrients from Waste Streams: A Critical Review. Crit. Rev. Environ. Sci. Technol. 45, 385-427.

Mo, W., Zhang, Q., 2013. Energy-nutrients-water nexus: integrated resource recovery in municipal wastewater treatment plants. J. Environ. Manage. 127, 255-67. 
Moerman, W., Carballa, M., Vandekerckhove, A., Derycke, D., Verstraete, W., 2009. Phosphate removal in agro-industry: Pilot- and full-scale operational considerations of struvite crystallization. Water Res. 43, 1887-1892.

Montastruc, L., Azzaro-Pantel, C., Pibouleau, L., Domenech, S., 2004. Use of genetic algorithms and gradient based optimization techniques for calcium phosphate precipitation. Chem. Eng. Process. Process Intensif. 43, 1289-1298.

More, T.T., Yadav, J.S.S., Yan, S., Tyagi, R.D., Surampalli, R.Y., 2014. Extracellular polymeric substances of bacteria and their potential environmental applications. J. Environ. Manage. 144, 1-25.

Morgan, J.W., Forster, C.F., Evison, L., 1990. A comparative study of the nature of biopolymers extracted from anaerobic and activated sludges. Water Res. 24, 743-750.

Mulder, M., Boogaard, J., Grent, A., Jonge, J. De, Palsma, B., Petri, C., Wetering, S. Van De, Worm, I., Zoutberg, G., 2014. Minder hard meer profijt Rapport 46. Amersfoort, The Netherlands.

Mullin, J.W. (John W., 2001. Crystallization, 4th ed, Chemical, Petrochemical \& Process. Butterworth-Heinemann.

Muster, T.H., Douglas, G.B., Sherman, N., Seeber, A., Wright, N., Güzükara, Y., 2013. Towards effective phosphorus recycling from wastewater: quantity and quality. Chemosphere 91, 676-84.

$\mathbf{N}$

Nättorp, A., Remmen, K., Remy, C., 2017. Cost assessment of different routes for phosphorus recovery from wastewater using data from pilot and production plants. Water Sci. Technol. 76, 413-424.

Nijhuis, A.W.G., Nejadnik, M.R., Nudelman, F., Walboomers, X.F., Te Riet, J., Habibovic, P., Tahmasebi Birgani, Z., Li, Y., Bomans, P.H.H., Jansen, J. a, Sommerdijk, N.A.J.M., Leeuwenburgh, S.C.G., 2014. Enzymatic pH control for biomimetic deposition of calcium phosphate coatings. Acta Biomater. 10, 931-939.

$\mathbf{O}$

Östman, M., Lindberg, R.H., Fick, J., Björn, E., Tysklind, M., 2017. Screening of biocides, metals and antibiotics in Swedish sewage sludge and wastewater. Water Res. 115, 318328.

\section{$\mathbf{P}$}

Penn, R., Ward, B.J., Strande, L., Maurer, M., 2018. Review of synthetic human faeces and faecal sludge for sanitation and wastewater research. Water Res. 132, 222-240.

Pereira, M.A., Roest, K., Stams, A.J.M., Mota, M., Alves, M., Akkermans, A.D.L., 2002. Molecular monitoring of microbial diversity in expanded granular sludge bed (EGSB) reactors treating oleic acid. FEMS Microbiol. Ecol. 41, 95-103. 
Pevere, A., Guibaud, G., Van Hullebusch, E., Lens, P., Baudu, M., 2006. Viscosity evolution of anaerobic granular sludge. Biochem. Eng. J. 27, 315-322.

Poortvliet, P.M., Sanders, L., Weijma, J., De Vries, J.R., 2018. Acceptance of new sanitation: The role of end-users' pro-environmental personal norms and risk and benefit perceptions. Water Res. 131, 90-99.

\section{Q}

Quintero, R.R., Garbarino, E., Saveyn, H., Wolf, O., 2015. Revision of the EU Ecolabel Criteria for Soil Improvers and Growing Media.

\section{$\mathbf{R}$}

Radjenović, J., Petrović, M., Barceló, D., 2009. Fate and distribution of pharmaceuticals in wastewater and sewage sludge of the conventional activated sludge (CAS) and advanced membrane bioreactor (MBR) treatment. Water Res. 43, 831-841.

Randall, D.G., Naidoo, V., 2018. Urine: The liquid gold of wastewater. J. Environ. Chem. Eng. 6, 2627-2635.

Ren, T.T., Liu, L., Sheng, G.P., Liu, X.W., Yu, H.Q., Zhang, M.C., Zhu, J.R., 2008. Calcium spatial distribution in aerobic granules and its effects on granule structure, strength and bioactivity. Water Res. 42, 3343-3352.

Rico, C., García, H., Rico, J.L., 2011. Physical-anaerobic-chemical process for treatment of dairy cattle manure. Bioresour. Technol. 102, 2143-2150.

Robinson, T.P., Thornton, P.K., Franceschini, G., Kruska, R.L., Chiozza, F., Notenbaert, A., Cecchi, G., Herrero, M., Epprecht, M., Fritz, S., You, L., Conchedda, G., See, L., 2011. Global livestock production systems. Food and Agriculture Organization of the United Nations (FAO) and International Livestock Research Institute (ILRI), Rome.

Rochex, A., Godon, J.J., Bernet, N., Escudié, R., 2008. Role of shear stress on composition, diversity and dynamics of biofilm bacterial communities. Water Res. 42, 4915-4922.

Roefs, I., Meulman, B., Vreeburg, J.H.G., Spiller, M., 2017. Centralised, decentralised or hybrid sanitation systems? Economic evaluation under urban development uncertainty and phased expansion. Water Res. 109, 274-286.

Rohde, R., 2016. Untersuchungen zur Feststoffbildung in Unterdrucksystemen für den Schwarzwassertransport. Rhombos Verlag. Bauhaus-Universität Weimar.

Rokidi, S., Combes, C., Koutsoukos, P.G., 2011. The Calcium Phosphate - Calcium Carbonate System: Growth of Octacalcium Phosphate on Calcium Carbonates. Cryst. Growth Des. $11,1683-1688$.

Roser, M., Ortiz-Ospina, E., 2018. World Population Growth URL https://ourworldindata.org/world-population-growth (accessed 7.10.18).

Royal commission on sewage disposal, 1915. Final report of the commissioners appointed to inquire and report what methods of treating and disposing of sewage (including any liquid from any factory or manufacturing process) may properly be adopted. General summary of conclusions and recommendations. London, H. M. Stationery office, London. 
Rule, K.L., Comber, S.D.W., Ross, D., Thornton, A., Makropoulos, C.K., Rautiu, R., 2006. Diffuse sources of heavy metals entering an urban wastewater catchment. Chemosphere 63, 64-72.

Russell, A.D., 2003. Lethal effects of heat on bacterial physiology and structure. Sci. Prog.

Rydin, Y., Bleahu, A., Davies, M., Dávila, J.D., Friel, S., De Grandis, G., Groce, N., Hallal, P.C., Hamilton, I., Howden-Chapman, P., Lai, K.M., Lim, C.J., Martins, J., Osrin, D., Ridley, I., Scott, I., Taylor, M., Wilkinson, P., Wilson, J., 2012. Shaping cities for health: Complexity and the planning of urban environments in the 21 st century. Lancet 379 , 2079-2108.

\section{$\mathbf{S}$}

Sajadian, M., Khoshbakht, K., Liaghati, H., Veisi, H., Mahdavi Damghani, A., 2017. Developing and quantifying indicators of organic farming using analytic hierarchy process. Ecol. Indic. 83, 103-111.

Saner, A.B., Mungray, A.K., Mistry, N.J., 2016. Treatment of distillery wastewater in an upflow anaerobic sludge blanket (UASB) reactor. Desalin. Water Treat. 57, 4328-4344.

Santen, R.A. van, 1984. The Ostwald step rule. J. Phys. Chem 88, 5768-5769.

Sato, S., Neves, E.G., Solomon, D., Liang, B., Lehmann, J., 2009. Biogenic calcium phosphate transformation in soils over millennial time scales. J. Soils Sediments 9, 194-205.

Scardi, P., Leoni, M., Beyerlein, K.R., 2011. On the modelling of the powder pattern from a nanocrystalline material. Zeitschrift fur Krist. 226, 924-933.

Schiermeier, Q., Tollefson, J., Scully, T., Witze, A., Morton, O., 2008. Energy alternatives: Electricity without carbon. Nature 454, 816-823.

Schiller, C., Epple, M., 2003. Carbonated calcium phosphates are suitable pH-stabilising fillers for biodegradable polyesters. Biomaterials 24, 2037-2043.

Schipper, W.J., Klapwijk, A., Potjer, B., Rulkens, W.H., Temmink, B.G., Kiestra, F.D., Lijmbach, A.C.M., 2001. Phosphate recycling in the phosphorus industry. Environ. Technol. 22, 1337-1345.

Schlosser, C.A., Strzepek, K., Gao, X., Fant, C., Blanc, É., Paltsev, S., Jacoby, H., Reilly, J., Gueneau, A., 2014. The Future of Global Water Stress: An Integrated Assessment. Earth's Futur. 2, 341-361.

Schmidt, J.E., Ahring, B.K., 1996. Granular sludge formation in upflow anaerobic sludge blanket (UASB) reactors. Biotechnol. Bioeng. 49, 229-46.

Schmidt, J.E., Ahring, B.K., 1994. Extracellular polymers in granular sludge from different upflow anaerobic sludge blanket (UASB) reactors. Appl. Microbiol. Biotechnol. 42, 457-462.

Schröder, J.J., Cordell, D., Smit, A.L., Rosemarin, A., 2010. Sustainable use of phosphorus Report 357 (European Union tender project ENV.B.1/ETU/2009/0025). Wageningen, The Netherlands.

Schröder, J.J., Smit, A.L., Cordell, D., Rosemarin, A., 2011. Improved phosphorus use efficiency in agriculture: A key requirement for its sustainable use. Chemosphere 84, 822-831. 
Seckler, M.M., Bruinsma, O.S.L., Rosmalen, G.M. van, 1996. Calcium phosphate precipitation in a fluidized bed in relation to process conditions: a black box approach. Water Res. 30, 1677-1685.

Seufert, V., Ramankutty, N., Mayerhofer, T., 2017. What is this thing called organic? - How organic farming is codified in regulations. Food Policy 68, 10-20.

Shao, X., Peng, D., Teng, Z., Ju, X., 2008. Treatment of brewery wastewater using anaerobic sequencing batch reactor (ASBR). Bioresour. Technol. 99, 3182-3186.

Shen, C.F., Kosaric, N., Blaszczyk, R., 1993. The Effect of Selected Heavy Metals (Ni ,Co and $\mathrm{Fe}$ ) on Anaerobic Granules and Their Extracellular Polymeric Substances (EPS). Water Res. 27, 25-33.

Shin, H.S., Paik, B.C., 1990. Improved performance of upflow anaerobic sludge blanket (UASB) reactors by operating alternatives. Biotechnol. Lett. 12, 469-474.

Show, K.Y., Wang, Y., Foong, S.F., Tay, J.-H., 2004. Accelerated start-up and enhanced granulation in upflow anaerobic sludge blanket reactors. Water Res. 38, 2292-2303.

Sindall, R., Bridgeman, J., Carliell-Marquet, C., 2013. Velocity gradient as a tool to characterise the link between mixing and biogas production in anaerobic waste digesters. Water Sci. Technol. 67, 2800-2806.

Smajgl, A., Ward, J., Pluschke, L., 2016. The water - food - energy Nexus - Realising a new paradigm. J. Hydrol. 533, 533-540.

Smil, V., 2002. Nitrogen and Food Production: Proteins for Human Diets. AMBIO A J. Hum. Environ. 31, 126.

Smit, A.L., Middelkoop, J.C. Van, Dijk, W. Van, Reuler, H. Van, Buck, A.J. De, Sanden, P.A.C.M. Van De, 2010a. A quantification of phosphorus flows in the Netherlands through agricultural production, industrial processing and households. Report 364, Plant Research International, part of Wageningen UR, Business Unit Agrosystems, DLO Foundation, Wageningen, The Netherlands.

Smit, A.L., Middelkoop, J.C. Van, Dijk, W. Van, Reuler, H. Van, Buck, A.J. De, Sanden, P.A.C.M. Van De, 2010b. A quantification of phosphorus flows in The Netherlands through agriculture, industry and households. Report 364, Plant Research International, part of Wageningen UR, Business Unit Agrosystems, DLO Foundation, Wageningen, The Netherlands.

Soare, A., Lakerveld, R., Van Royen, J., Zocchi, G., Stankiewicz, A.I., Kramer, H.J.M., 2012. Minimization of attrition and breakage in an airlift crystallizer. Ind. Eng. Chem. Res. 51, 10895-10909.

Sokolichin, A., Eigenberger, G., Lapin, A., 2004. Simulation of Buoyancy Driven Bubbly Flow: Established Simplifications and Open Questions. AIChE J. 50, 24-45.

Song, Y., Hahn, H.H., Hoffmann, E., 2002. Effects of solution conditions on the precipitation of phosphate for recovery: A thermodynamic evaluation. Chemosphere 48, 1029-1034.

Song, Y., Hahn, H.H., Hoffmann, E., Weidler, P.G., 2006a. Effect of humic substances on the precipitation of calcium phosphate. J. Environ. Sci. 18, 852-857.

Song, Y., Weidler, P.G., Berg, U., Nüesch, R., Donnert, D., 2006b. Calcite-seeded crystallization of calcium phosphate for phosphorus recovery. Chemosphere 63, 236243. 
Squire, G.R., Hawes, C., Valentine, T.A., Young, M.W., 2015. Degradation rate of soil function varies with trajectory of agricultural intensification. Agric. Ecosyst. Environ. $202,160-167$.

Stams, A., 1994. Metabolic Interactions Between Anaerobic-Bacteria in Methanogenic Environments. Antonie Van Leeuwenhoek Int. J. Gen. Mol. Microbiol. 66, 271-294.

Sudmalis, D., Gagliano, M.C., Pei, R., Grolle, K., Plugge, C.M., Rijnaarts, H.H.M., Zeeman, G., Temmink, H., 2018. Fast anaerobic sludge granulation at elevated salinity. Water Res. 128, 293-303.

$\mathbf{T}$

Tao, J., Pan, H., Zeng, Y., Xu, R., Tang, R., 2007. Roles of amorphous calcium phosphate and biological additives in the assembly of hydroxyapatite nanoparticles. J. Phys. Chem. B 111, 13410-13418.

Tchobanoglous, G., Burton, F.L., Stensel, H.D., 2004. Wastewater Engineering: Treatment and Reuse, 4th Editio. ed. McGraw-Hill, New York, US.

Tervahauta, T., Bryant, I.M., Leal, L.H., Buisman, C.J.N., Zeeman, G., 2014a. Improved energy recovery by anaerobic grey water sludge treatment with black water. Water (Switzerland) 6, 2436-2448.

Tervahauta, T., Hoang, T., Hernández Leal, L., Zeeman, G., Buisman, C.J.N., 2013. Prospects of Source-Separation-Based Sanitation Concepts: A Model-Based Study. Water 5, 1006-1035.

Tervahauta, T., Rani, S., Hernández Leal, L., Buisman, C.J.N., Zeeman, G., 2014b. Black water sludge reuse in agriculture: are heavy metals a problem? J. Hazard. Mater. 274, 229-236.

Tervahauta, T., Weijden, R.D. Van Der, Flemming, R.L., Hernández Leal, L., Zeeman, G., Buisman, C.J.N., 2014c. Calcium phosphate granulation in anaerobic treatment of black water: A new approach to phosphorus recovery. Water Res. 48, 632-642.

Thibodeau, C., Monette, F., Glaus, M., Laflamme, C.B., 2011. Economic viability and critical influencing factors assessment of black water and grey water source-separation sanitation system. Water Sci. Technol. 64, 2417-2424.

Tiwari, M.K., Guha, S., Harendranath, C.S., Tripathi, S., 2006. Influence of extrinsic factors on granulation in UASB reactor. Appl. Microbiol. Biotechnol. 71, 145-154.

Tsuzuki, Y., 2014. Pollutant Discharge and Water Quality in Urbanisation, 1st ed. Springer International Publishing.

$\mathbf{U}$

U.S. Geological Survey, 2015. Mineral Commodity Summaries 2015. U.S. Geol. Surv. 196. 
V

Vavilin, V.A., Fernandez, B., Palatsi, J., Flotats, X., 2008. Hydrolysis kinetics in anaerobic degradation of particulate organic material: An overview. Waste Manag. 28, 939-951.

VDLUFA, (Verband Deutscher Landwirtschaftlicher Untersuchungs und Forschungsanstalten), 1995. Düengemitteluntersuchung - Phosphat (citronensäurelöslichen). Methoden Buch II.

Vlaeminck, S.E., Terada, A., Smets, B.F., Van Der Linden, D., Boon, N., Verstraete, W., Carballa, M., 2009. Nitrogen removal from digested black water by one-stage partial nitritation and anammox. Environ. Sci. Technol. 43, 5035-5041.

\section{W}

Wang, C.G., Liao, J.W., Gou, B.D., Huang, J., Tang, R.K., Tao, J.H., Zhang, T.L., Wang, K., 2009. Crystallization at multiple sites inside particles of amorphous calcium phosphate. Cryst. Growth Des. 9, 2620-2626.

Wang, H., Zhu, S., Qu, B., Zhang, Y., Fan, B., 2018. Anaerobic treatment of source-separated domestic bio-wastes with an improved upflow solid reactor at a short HRT. J. Environ. Sci. (China) 66, 255-264.

Wang, L., Ruiz-Agudo, E., Putnis, C. V., Menneken, M., Putnis, A., 2012. Kinetics of calcium phosphate nucleation and growth on calcite: Implications for predicting the fate of dissolved phosphate species in alkaline soils. Environ. Sci. Technol. 46, 834-842.

Wang, X., Shi, J., Li, Z., Zhang, S., Wu, H., Jiang, Z., Yang, C., Tian, C., 2014. Facile onepot preparation of chitosan/calcium pyrophosphate hybrid microflowers. ACS Appl. Mater. Interfaces 6, 14522-14532.

Wilén, B.M., Jin, B., Lant, P., 2003. The influence of key chemical constituents in activated sludge on surface and flocculating properties. Water Res. 37, 2127-2139.

Wirtz, R. a, Dague, R.R., 1996. Enhancement of granulation and start-up in the anaerobic sequencing batch reactor. Water Environ. Res. 68, 883-892.

Wyant, K.A., Corman, J.R., Elser, J.J., 2013. Phosphorus, Food, and Our Future, School of Life Sciences, Arizona State University. Oxford University Press, Tempe, AZ, United States.

\section{X}

Xie, B., Halter, T.J., Borah, B.M., Nancollas, G.H., 2014. Tracking amorphous precursor formation and transformation during induction stages of nucleation. Cryst. Growth Des. 14, 1659-1665.

\section{Y}

Yoda, M., Kitagawa, M., Miyaji, Y., 1989. Granular sludge formation in the anaerobic expanded micro--carrier bed process. Water Sci. Technol. 21, 109-120. 
Yu, H.Q., Tay, J.-H., Fang, H.H.P., 2001. The roles of calcium in sludge granulation during UASB reactor start-up. Water Res. 35, 1052-1060.

Yu, H.Q., Tay, J.-H., Fang, H.H.P., 1999. Effects of Added Powdered and Granular Activated Carbons on Start-Up Performance of UASB Reactors. Environ. Technol. 20, 1095-1101.

Yuan, Z., Pratt, S., Batstone, D.J., 2012. Phosphorus recovery from wastewater through microbial processes. Curr. Opin. Biotechnol. 23, 878-883.

\section{$\mathbf{Z}$}

Zeeman, G., 2012. New sanitation: bridging cities and agriculture. Wageningen, The Netherlands.

Zeeman, G., Lettinga, G., 1999. The role of anaerobic digestion of domestic sewage in closing the water and nutrient cycle at community level. Water Sci. Technol. 39, 187-194.

Zhou, W., Imai, T., Ukita, M., Sekine, M., Higuchi, T., 2006. Triggering forces for anaerobic granulation in UASB reactors. Process Biochem. 41, 36-43.

Zoetemeyer, R.J., van den Heuvel, J.C., Cohen, A., 1982. pH influence on acidogenic dissimilation of glucose in an anaerobic digestor. Water Res. 16, 303-311. 


\section{Appendices}

\section{Appendix A}

\section{A1. Polyvinylchloride upflow column for separation of granules}

Sludge samples ( $150 \mathrm{ml}$ with $11.5 \pm 0.1$ gTSS) were taken at $30 \mathrm{~cm}$ above the bottom of the UASB reactor (total height of $1.5 \mathrm{~m}$ ) and separated by density in 5 fractions using a polyvinylchloride upflow column, with $1 \mathrm{~cm}$ diameter and $1 \mathrm{~m}$ high (Figure A1.1). The column was operated for 6 min with an upflow velocity of $57 \mathrm{~m} \mathrm{~h}^{-1}$ for each separation. Effluent from the UASB reactor, which first was paper filtrated for removal of residual suspended solids, was used as mobile phase. Simultaneously, $\mathrm{N}_{2}$ and $\mathrm{CO}_{2}$ were used to purge $\mathrm{O}_{2}$ from the mobile phase and to control the $\mathrm{pH}(7.5 \pm 0.02)$. The fractions were collected and kept under oxygen-free, $\mathrm{pH}(7.5)$, and temperature $\left(25^{\circ} \mathrm{C}\right)$ controlled conditions for further analysis. Visually, fraction F1 was composed of mainly granules, fractions F2 and F3 were composed of granules and dispersed smaller particles, and fractions F4 and F5 were composed of mainly flocculent sludge and no granules were observed.

The TSS in each sludge sample from the UASB reactor were fractionated (F1 to F5) in the separation column as: $35 \pm 7 \%$ for $\mathrm{F} 1$, which was visually mainly granules; $11 \pm 4 \%$ for $\mathrm{F} 2 ; 6 \pm 1.5 \%$ for $\mathrm{F} 3 ; 6 \pm 1 \%$ for $\mathrm{F} 4$; and $42 \pm 8 \%$ for $\mathrm{F} 5$, which is considered to be flocculent sludge. The sum of TSS from all the fractions represented $85 \pm 26 \%(9.7 \pm 2.9 \mathrm{~g})$ of the TSS sampled from the UASB reactor; the high deviation is a result of the correlation between the average TSS concentration of unfractionated and fractionated sludge samples. Figure A1.2 shows the average organic (VSS), inorganic (Ash), P, Ca, and Mg contents of the 5 fractions from two different sludge samples. The ash content decreased from F1 to F5 (from $60 \pm 5$ to $20 \pm 5 \mathrm{wt} \%$ ). This is most likely related to the decreasing concentration of $\mathrm{P}$ and $\mathrm{Ca}$ from $\mathrm{F} 1$ (8 and $17 \mathrm{wt} \%$, respectively) to F5 ( 2 and $5 \mathrm{wt} \%$, respectively). The concentration of $\mathrm{Mg}$ was below $0.4 \pm 0.2 \mathrm{wt} \%$ for all the fractions, suggesting low levels of $\mathrm{Mg}$-based precipitates, such as struvite. The aluminum, copper, iron, potassium, and sodium contents were below $0.5 \mathrm{wt} \%$ for all the fractions. The $\mathrm{P}$ content of $\mathrm{F} 1$ granules was $205 \mathrm{mgP} \mathrm{g}^{-1} \mathrm{VSS}$. The $\mathrm{Ca} / \mathrm{P}$ molar ratio of the fractions decreased from top (F5) to bottom (F1) of the column (Figure A1.2, right vertical axis). 


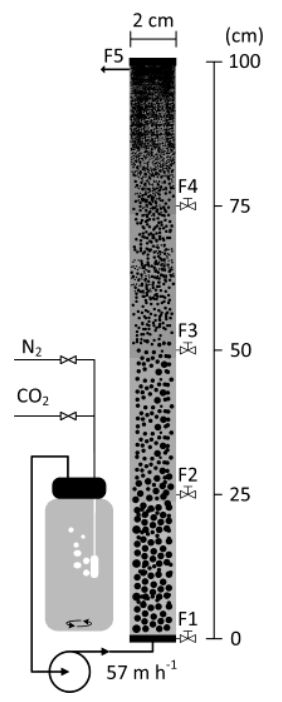

Figure A1.1 Schematic representation of the polyvinylchloride upflow column used for separation of granules and flocculent sludge.

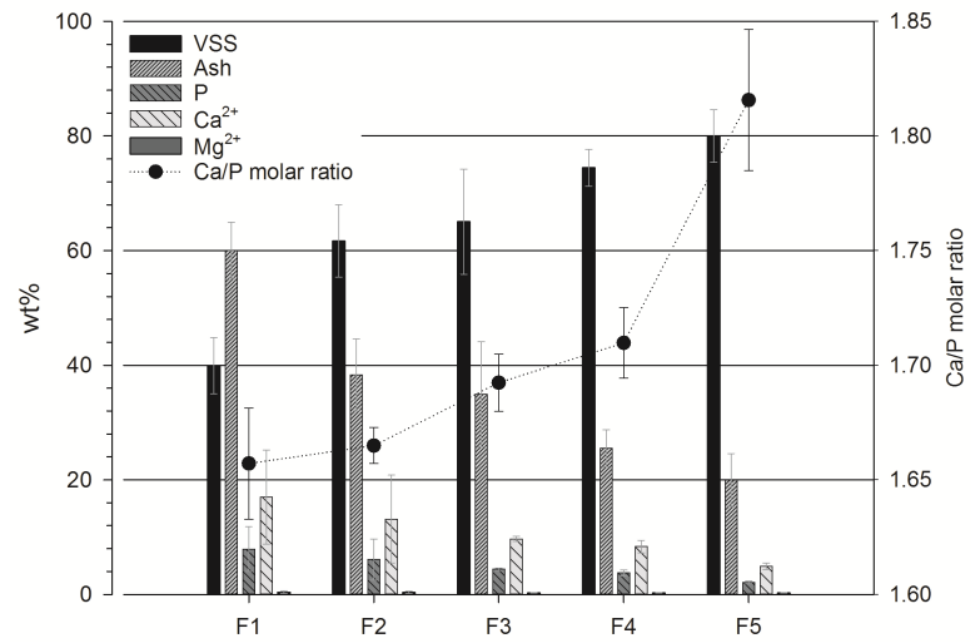

Figure A1.2 Average $\mathrm{P}, \mathrm{Ca}^{2+}$, and $\mathrm{Mg}^{2+}$ contents, organic and inorganic average percentages (VSS and Ash, respectively), and $\mathrm{Ca} / \mathrm{P}$ molar ratio of TSS from two sludge samples divided in 5 fractions by upflow motion, F1 being the densest fraction and mainly containing granules. 


\section{A2. Modeling of $\mathrm{HCO}_{3}^{-}, \mathrm{H}^{+}$, and $\mathrm{H}_{2}$ flows in the interphase between bulk and granule}

The anaerobic digestion model no. 1 (ADM1), previously reported by Batstone et al. (2002), was further optimized for anaerobic treatment of black water (BW) by Feng et al. (2006). In this study, the model concept and metabolic constants were used to calculate the mass balance of bicarbonate $\left(\mathrm{HCO}_{3}^{-}\right)$, protons $\left(\mathrm{H}^{+}\right)$, and hydrogen $\left(\mathrm{H}_{2}\right)$ during the anaerobic digestion of source separated BW. The aim was the correlation between the internal production and consumption of protons $\left(\mathrm{H}^{+}\right)$from biochemical reactions, the production of $\mathrm{H}^{+}$from the deprotonation of $\mathrm{H}_{2} \mathrm{PO}_{4}^{-}$and $\mathrm{HPO}_{4}{ }^{2-}$ during formation of $\mathrm{Ca}_{\mathrm{x}}\left(\mathrm{PO}_{4}\right)_{\mathrm{y}}$, and the measured $\mathrm{pH}$ gradient in the granules. Modeled production of $\mathrm{CO}_{2}\left(\mathrm{HCO}_{3}{ }^{-}+\mathrm{H}^{+}\right)$and $\mathrm{CH}_{4}$ was compared with produced biogas composition during BW treatment in the UASB reactors used for this study. Additionally, the internal competition of $\mathrm{HCO}_{3}{ }^{-}$with $\mathrm{PO}_{4}{ }^{3-}$ for $\mathrm{Ca}^{2+}$ was assessed according to internal consumption of $\mathrm{HCO}_{3}{ }^{-}$, which reduced saturation state of $\mathrm{CaCO}_{3}$ phases in the granule.

The anaerobic digestion pathways were divided by location as reactor bulk, interface bulk-granule, and outer biofilm of the granule. The metabolic conversions included in the reactor bulk were hydrolysis/disintegration of solid and colloidal COD (carbohydrates, proteins and lipids) and acetoclastic methanogenesis of acetate (Ac) already in black water. Acidogenesis of monosaccharides (MS), amino acids (AA), and long chain fatty acids (LCFA) was assumed to occur in the interface bulk-granule, because produced $\mathrm{H}_{2}$ should be directly metabolized by hydrogenotrophic methanogens in the outer biofilm, otherwise degradation of propionate $(\mathrm{Pr})$ and butyrate $(\mathrm{Bt})$ is thermodynamically unfavourable $\left(\Delta G^{\circ}>0\right)$. Produced $\mathrm{H}_{2}$ is rapidly consumed to levels below $10^{-4} \mathrm{~atm}$, enabling degradation of $\mathrm{Pr}$ and $\mathrm{Bt}$ (Lier et al., 2008). Note that $\mathrm{H}_{2}$ was never detected in the produced biogas during the monitoring period of the three UASB reactors used for this study. In the outer biofilm, acetogenesis and hydrogenotrophic and acetoclastic methanogenesis were included with $\mathrm{CH}_{4}$ gas being the end product, which is stripped from the granules together with produced $\mathrm{CO}_{2}\left(\right.$ or $\mathrm{HCO}_{3}{ }^{-}$and the remaining $\mathrm{H}^{+}\left(\mathrm{H}_{2} \mathrm{CO}_{3}\right)$ ). Figure A2.1 describes the assumed location and substrates and products of each biochemical pathway as well as the yield of each product on the respective substrate $(f)$. 


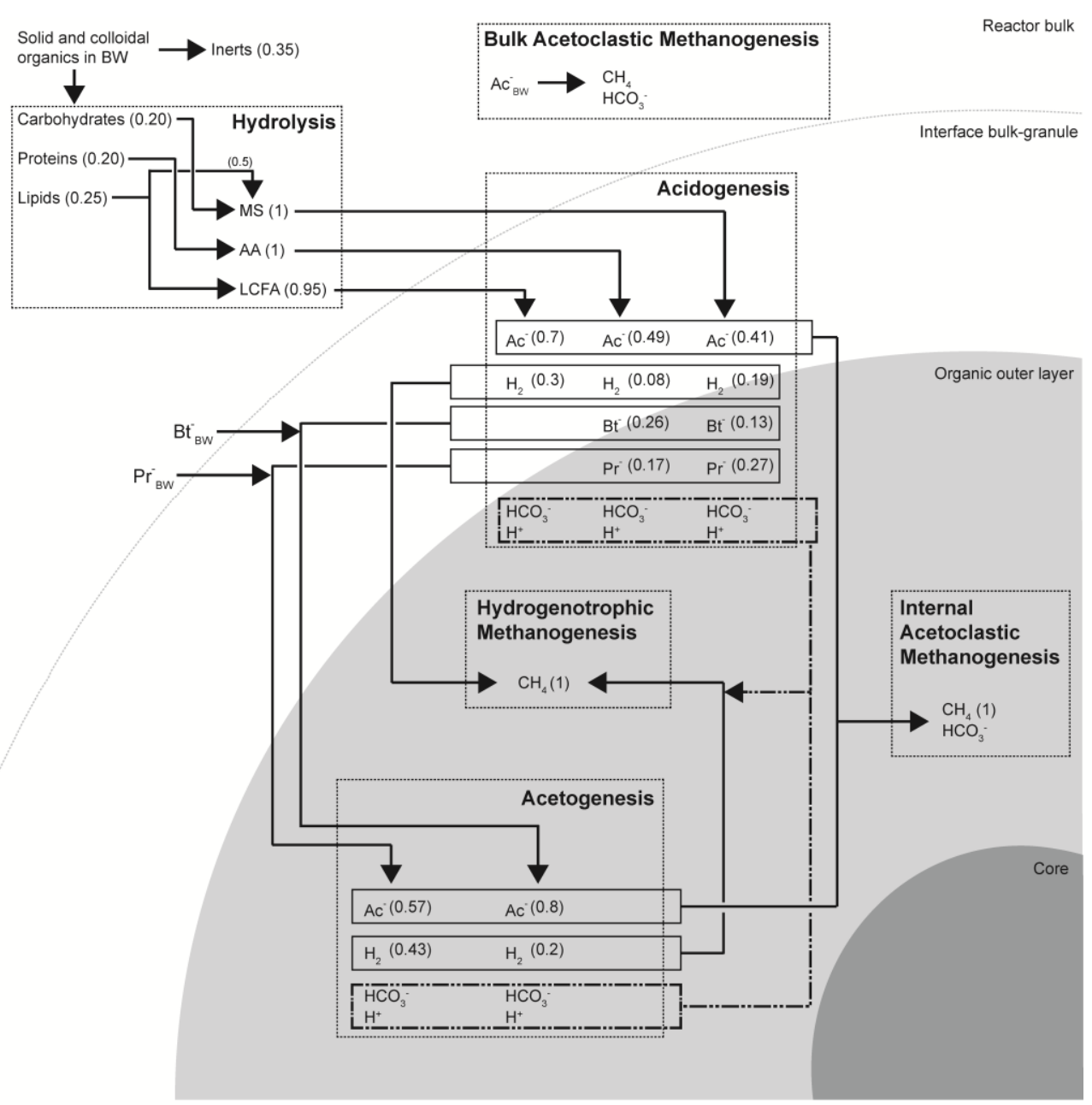

Figure A2.1 COD flux over the metabolic pathways of anaerobic digestion of BW (hydrolysis, acidogenesis, acetogenesis, and hydrogenotrophic and acetoclastic methanogenesis) and respective assumed location of each pathway (reactor bulk, interface bulk-granule, and organic outer layer). Between brackets, the yield of each product on the respective substrate $(f)$ is given.

The calculation was performed on a volumetric basis $\left(\mathrm{L}^{-1}\right)$, considering the solid, colloidal, and soluble COD and Ac, Pr, and Bt concentrations in BW. The COD flux (Figure A2.1) for each product $(x)$ of a substrate $(y)$ was calculated according to eq. A2.1 as described in Feng et al. (2006). The biomass growth was considered by incorporating the yield coefficient $(Y)$ given in Table A2.1 for each substrate. 
$P_{x}=S_{y}\left(1-Y_{y}\right) f_{x, y}$

Equation A2.1

where $P$ is the reaction product concentration $\left(\mathrm{gCOD} \mathrm{L}^{-1}\right), S$ is the substrate concentration $\left(\mathrm{gCOD} \mathrm{L}^{-1}\right), Y$ is the yield of biomass on the substrate $y\left(\mathrm{gCOD} \mathrm{g}^{-1} \mathrm{COD}\right)$ and $f$ is the yield of product $x$ on substrate $y\left(\mathrm{gCOD} \mathrm{g}^{-1} \mathrm{COD}\right)$.

Table A2.1 Values used for yield of biomass on each substrate ( $\left.Y, \mathrm{gCOD} \mathrm{g}^{-1} \mathrm{COD}\right)$ adapted from Feng et al. (2006).

\begin{tabular}{lll}
\hline Monosaccharides & $\boldsymbol{Y}_{\boldsymbol{M S}}$ & 0.1 \\
Amino Acids & $Y_{A A}$ & 0.08 \\
Long Chain Fatty Acids & $Y_{L C F A}$ & 0.06 \\
Butyrate & $Y_{B t}$ & 0.06 \\
Propionate & $Y_{P r}$ & 0.04 \\
Acetate & $Y_{A C}$ & 0.05 \\
Hydrogen & $Y_{H_{2}}$ & 0.06 \\
\hline
\end{tabular}

Then $\mathrm{HCO}_{3}{ }^{-}$or inorganic carbon $\left(I C\right.$, mol L ${ }^{-1}$ Bw) production and consumption was calculated based on the carbon balance for each metabolic pathway ( $m p=$ acidogenesis, acetogenesis, or methanogenesis) according to eq. A2.2.

$I C_{m p}=\sum_{i=1}^{n_{y}}\left(C_{y_{i}} S_{y_{i}}\right)-\sum_{i=1}^{n_{y}}\left(C_{B} S_{y_{i}} Y_{y_{i}}\right)-\sum_{z=1}^{n_{x}}\left(C_{x_{z}} P_{x_{z}}\right)$

Equation A2.2

where $n_{y}$ and $n_{x}$ are the number of substrates $\left(i=1, \ldots, n_{y}\right)$ and products $\left(z=1, \ldots, n_{x}\right)$ for each metabolic pathway as described in Figure A2.1 and $C$ is the carbon content of each component ( $\left.\mathrm{molC} \mathrm{g} \mathrm{g}^{-1} \mathrm{COD}\right)$ as described in Table A2.2.

Table A2.2 Carbon content of each component (molC g ${ }^{-1} \mathrm{COD}$ ), adapted from Feng et al. (2006).

\begin{tabular}{lll}
\hline Monosaccharides & $\boldsymbol{C}_{\boldsymbol{M S}}$ & $6 / 192$ \\
Amino Acids & $C_{A A}$ & 0.03 \\
Long Chain Fatty Acids & $C_{L C F A}$ & 0.0217 \\
Butyrate & $C_{B t}$ & $4 / 160$ \\
Propionate & $C_{P r}$ & $3 / 112$ \\
Acetate & $C_{A c}$ & $2 / 64$ \\
Hydrogen & $C_{H_{2}}$ & 0 \\
Methane & $C_{C H_{4}}$ & $1 / 64$ \\
Biomass & $C_{B}$ & $5 / 160$ \\
\hline
\end{tabular}


Production of $\mathrm{H}^{+}$(mol L-1 BW) was estimated by stoichiometry (eq. A2.3 to A2.7), considering the produced acetic $(\mathrm{HAc})$, propionic $(\mathrm{HPr})$, butyric $(\mathrm{HBt})$, and carbonic $\left(\mathrm{H}_{2} \mathrm{CO}_{3}\right)$ acids during each metabolic pathway $(m p)$ as described in Figure A2.1.

$$
\begin{aligned}
& \mathrm{C}_{12} \mathrm{H}_{22} \mathrm{O}_{11}+5 \mathrm{H}_{2} \mathrm{O} \rightarrow 4 \mathrm{C}_{2} \mathrm{H}_{3} \mathrm{O}_{2}^{-}+8 \mathrm{H}^{+}+8 \mathrm{H}_{2} \\
& \mathrm{C}_{12} \mathrm{H}_{22} \mathrm{O}_{11}+3 \mathrm{H}_{2} \mathrm{O} \rightarrow 2 \mathrm{C}_{2} \mathrm{H}_{3} \mathrm{O}_{2}^{-}+2 \mathrm{C}_{3} \mathrm{H}_{5} \mathrm{O}_{2}^{-}+2 \mathrm{HCO}_{3}^{-}+6 \mathrm{H}^{+}+2 \mathrm{H}_{2} \\
& \mathrm{C}_{12} \mathrm{H}_{22} \mathrm{O}_{11}+5 \mathrm{H}_{2} \mathrm{O} \rightarrow 2 \mathrm{C}_{4} \mathrm{H}_{7} \mathrm{O}_{2}^{-}+4 \mathrm{HCO}_{3}^{-}+6 \mathrm{H}^{+}+4 \mathrm{H}_{2} \\
& \mathrm{C}_{3} \mathrm{H}_{5} \mathrm{O}_{2}^{-}+2 \mathrm{H}_{2} \mathrm{O} \rightarrow 2 \mathrm{C}_{2} \mathrm{H}_{3} \mathrm{O}_{2}^{-}+\mathrm{H}^{+}+2 \mathrm{H}_{2} \\
& \mathrm{C}_{4} \mathrm{H}_{7} \mathrm{O}_{2}^{-}+3 \mathrm{H}_{2} \mathrm{O} \rightarrow \mathrm{C}_{2} \mathrm{H}_{3} \mathrm{O}_{2}^{-}+\mathrm{HCO}_{3}^{-}+\mathrm{H}^{+}+3 \mathrm{H}_{2} \\
& \mathrm{C}_{2} \mathrm{H}_{3} \mathrm{O}_{2}^{-}+\mathrm{H}_{2} \mathrm{O} \rightarrow \mathrm{CH}_{4}+\mathrm{HCO}_{3}^{-}
\end{aligned}
$$

Equation A2.5

Equation A2.6

Equation A2.7

Equation A2.8

Kinetic parameters were not considered because operating temperature and reactor conditions were different when compared to conditions used in model from Feng et al. (2006). Moreover, input values were measured values corresponding the COD removal efficiencies, and therefore, kinetic degradation rate of the input COD was within the operating HRT (8 days). Metabolic inhibition could occur due to $\mathrm{pH}$ fluctuations, ammonium concentration, and accumulation of volatile fatty acids (VFA) (Chen et al., 2008). However, none of these inhibition factors were observed during the monitoring period of the three UASB reactors treating BW used in this study. The $\mathrm{pH}$ in $\mathrm{BW}$ and effluent fluctuated between 7 and 8 , ammonium concentration did not exceed $1.2 \mathrm{~g} \mathrm{~L}^{-1}$, and effluent VFA concentration was always $<0.02 \mathrm{~g} \mathrm{~L}^{-1}$.

Reactor bulk. The average of removed solids and colloidal COD was obtained during the monitoring period (6.9 $\left.\mathrm{gCOD} \mathrm{L}^{-1}\right)$. According to Feng et al. (2006), 35\% is nonbiodegradable COD $\left(2.4 \mathrm{gCOD} \mathrm{L}^{-1}\right), 20 \%$ are carbohydrates $\left(1.4 \mathrm{gCOD} \mathrm{L}^{-1}\right), 20 \%$ are proteins $\left(1.4 \mathrm{gCOD} \mathrm{L}^{-1}\right)$ and $25 \%$ are lipids $\left(1.7 \mathrm{gCOD} \mathrm{L}^{-1}\right)$. Carbohydrates and proteins yield MS and AA, respectively, and lipids yield 95\% LCFA and 5\% MS. Acetate already in black water (1.07 $\left.\mathrm{gCOD} \mathrm{L}^{-1}\right)$ yields $16 \mathrm{mM} \mathrm{CH}_{4}\left(1.02 \mathrm{gCOD} \mathrm{L}^{-1}\right)$ and $16 \mathrm{mM} \mathrm{HCO}_{3}^{-}$in the reactor bulk according to eq. A2.1 and A2.8.

Interface bulk -granule. In the interface bulk-granule, MS, AA and LCFA were acidified to Bt, $\mathrm{Pr}, \mathrm{Ac}$ and $\mathrm{H}_{2}$ as described in Figure A2.1. In this step, $57.1 \mathrm{mM}$ of $\mathrm{H}^{+}$is created from the produced $\mathrm{HBt}(3.2 \mathrm{mM}), \mathrm{HPr}(5.1 \mathrm{mM}), \mathrm{HAc}(34.9 \mathrm{mM})$ and $\mathrm{H}_{2} \mathrm{CO}_{3}(13.9$ $\mathrm{mM})$. The potential formation of $\mathrm{HCO}_{3}{ }^{-}$is then $13.9 \mathrm{mM}$. Additionally, $\mathrm{H}_{2}$ is yielded $(51 \mathrm{mM})$ from all substrates considered in this pathway (MS, AA, and LCFA). 
Organic outer layer. Because $\mathrm{H}_{2}$ is produced during acidogenesis formed $\mathrm{Bt}$ and $\mathrm{Pr}$ are only degraded when $\mathrm{H}_{2}$ is depleted as aforementioned. Thus, hydrogenotrophic methanogenesis and acetogenesis are modeled in the outer biofilm where the proximity is hypothetical higher when compared to the bulk of the reactor. $\mathrm{Bt}(0.24 \mathrm{mM})$ and $\operatorname{Pr}(4.57 \mathrm{mM})$ in BW were also modeled in the outer biofilm. Degradation of Bt and Pr yielded $15.7 \mathrm{mM}$ of HAc, $34.5 \mathrm{mM}$ of $\mathrm{H}_{2}$ and $9 \mathrm{mM}$ of $\mathrm{H}_{2} \mathrm{CO}_{3}$. The latter is obtained by the estimation of $I C_{m p}$ and is related to $\mathrm{HCO}_{3}{ }^{-}$formation. Then, the calculated production $\mathrm{H}^{+}$was $12.5 \mathrm{mM}$, considering the stoichiometry in eq. A2.6 and A2.7. During acetogenesis $\mathrm{HCO}_{3}{ }^{-}$is produced only from degradation of $\operatorname{Pr}(9.7 \mathrm{mM})$. The produced $I C_{\text {acetogenesis }}$ was $9 \mathrm{mM}$ which is close to the expected since $4 \%$ of the COD is used growth of propionate degraders. The total $\mathrm{H}_{2}$ produced during acidogenesis and acetogenesis $(85.5 \mathrm{mM})$ yielded $21.1 \mathrm{mM} \mathrm{CH}_{4}$, consuming the same amount of $\mathrm{HCO}_{3}{ }^{-}$and $\mathrm{H}^{+}(21.1 \mathrm{mM}$ of each). Acetoclastic methanogenesis of $\mathrm{Ac}$ in the outer biofilm $(50.6 \mathrm{mM})$ generated $48.1 \mathrm{mM}$ of $\mathrm{CH}_{4}$ and the same amount of $\mathrm{HCO}_{3}$. Considering that all $\mathrm{H}^{+}$produced and not metabolized during hydrogenotrophic are present as $\mathrm{CO}_{2}\left(\mathrm{HCO}_{3}{ }^{-}+\mathrm{H}^{+}\right)$, the biogas composition with the respect of $\mathrm{CH}_{4}$ and $\mathrm{CO}_{2}$ is $62 \%$ and $38 \%$, respectively. Note that $\mathrm{H}^{+}$formed by deprotonation of $\mathrm{H}_{2} \mathrm{PO}_{4}{ }^{-}$and $\mathrm{HPO}_{4}{ }^{2-}$ during $\mathrm{Ca}_{\mathrm{x}}\left(\mathrm{PO}_{4}\right)_{\mathrm{y}}$ formation were included in the calculation. The surplus of $\mathrm{HCO}_{3}{ }^{-}$in the granule $(0.5 \mathrm{mM})$, can potentially precipitate as $\mathrm{CaCO}_{3}$. The methanization rate obtained was 0.57 gCOD-CH ${ }^{1}$ COD-BW.

\section{A3. Other pH profile of CaP granules}

Figure A3.1 left shows the $\mathrm{pH}$ profile of 11 granule samples from the edge of the granule $(0 \mathrm{~mm})$ until the highest $\mathrm{pH}$ value measured in the entire $\mathrm{pH}$ profile. For correlation of the $\mathrm{pH}$ interval with the granule depth it was used an averaging with $95 \%$ confidence interval of the depth normalized distribution of the $\mathrm{pH}$ measurements (Figure A3.1 right). 

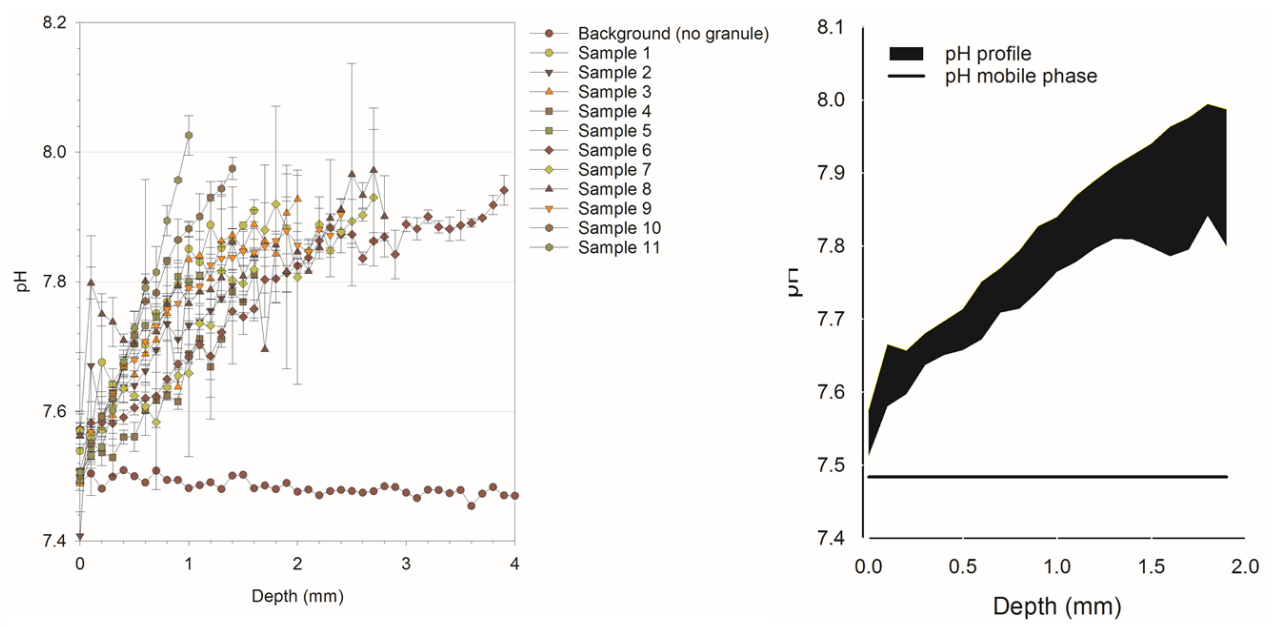

Figure A3.1 pH profile of 11 granule samples from the edge of the granule $(0 \mathrm{~mm})$ until the highest $\mathrm{pH}$ value measured, which was different for each sample because of the different granule size (left). Averaging with $95 \%$ confidence interval of the depth normalized $\mathrm{pH}$ profiles measured versus the granule depth from the edge $(0 \mathrm{~mm})$ to the estimated center $(2$ mm) (right).

\section{Appendix B}

\section{B1. Experimental setup}

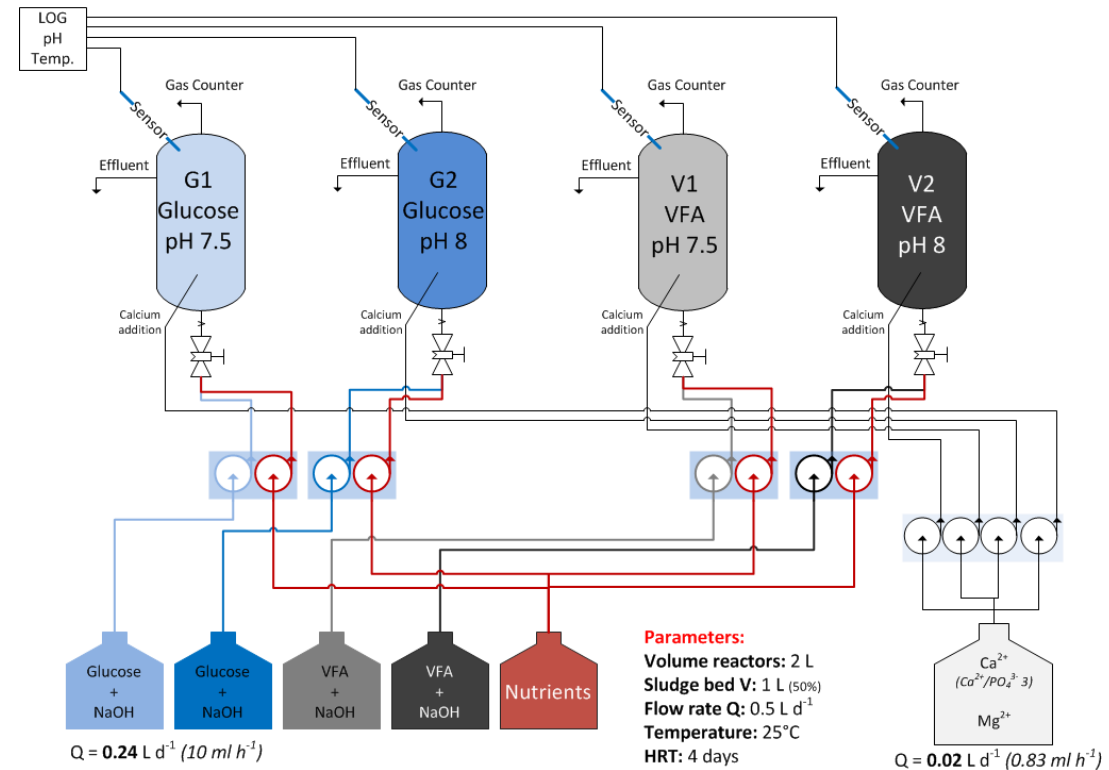

Figure B1.1 Scheme of the experimental setup. 
B2. Bulk pH, daily $\mathrm{CH}_{4}$ production, and $\mathrm{PO}_{4}{ }^{3-}$ and $\mathrm{Ca}^{2+}$ removals
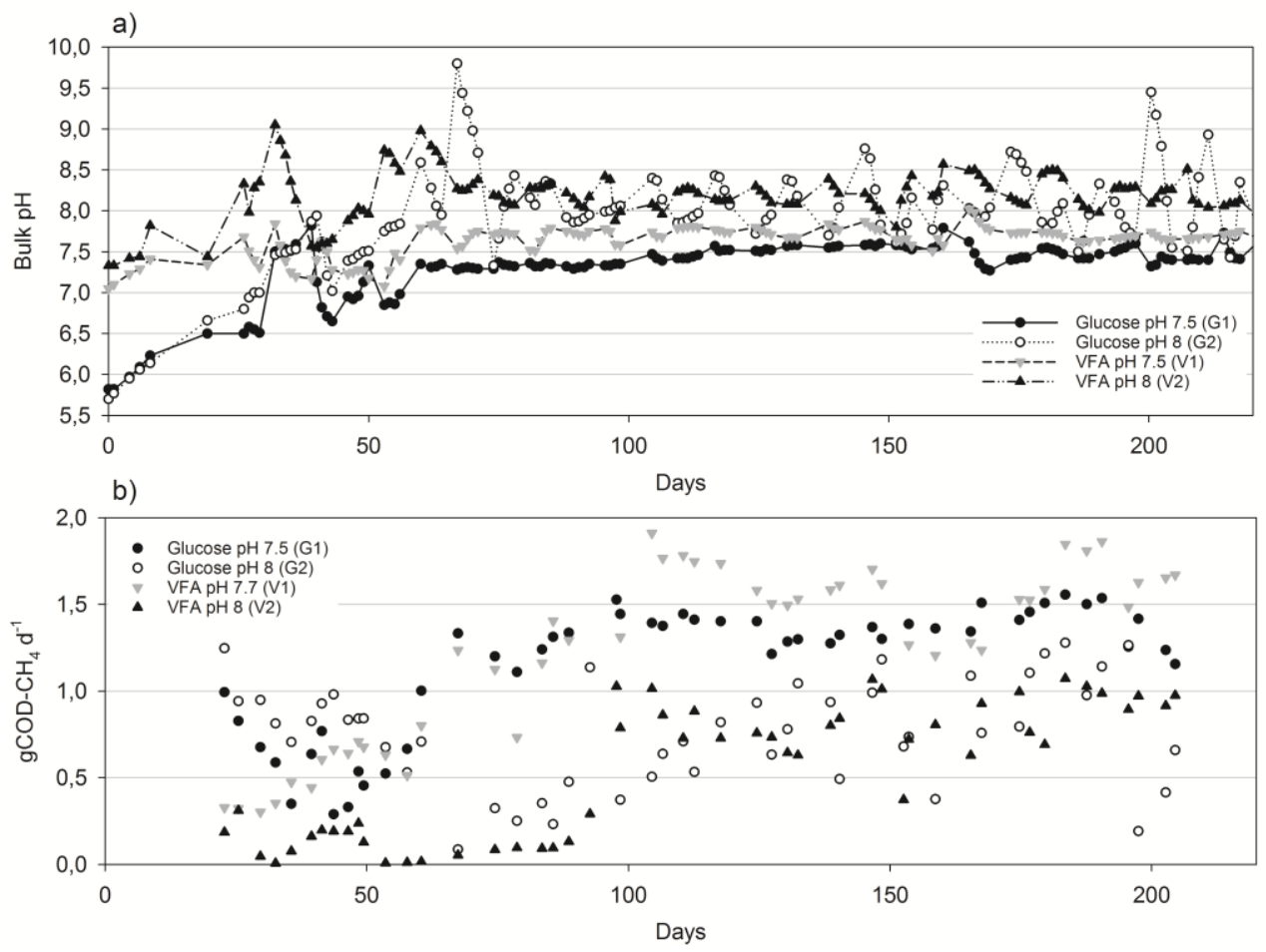

Figure B2.1 Bulk pH (a) and $\mathrm{CH}_{4}$ production (b) for each reactor over the operation period.

Table B2.1 NaOH dosed and concentration of total $\mathrm{Na}^{+}$in the influent streams.

\begin{tabular}{lccccccccc}
\hline & & $\mathbf{G 1}$ & & $\mathbf{G 2}$ & & $\mathbf{V 1}$ & & V2 \\
& Unit & Glucose & $s d$ & Glucose & $s d$ & VFA & $s d$ & VFA & $S d$ \\
\hline $\mathrm{OH}^{-}$dosed as $\mathrm{NaOH}$ & $\mathrm{mM}$ & $\mathbf{3 3}$ & 7 & $\mathbf{5 3}$ & 17 & $\mathbf{6}$ & 5 & $\mathbf{1 9}$ & 7 \\
\hline $\begin{array}{l}n\left[\mathrm{OH}^{-} \text {dosed }\right] / n\left[\mathrm{Na}^{2+}\right] \text { in } \\
\text { the mixed influent }\end{array}$ & $\begin{array}{l}\mathrm{mol} / \\
\mathrm{mol}\end{array}$ & $\mathbf{0 . 5 6}$ & 0.21 & $\mathbf{0 . 6 8}$ & 0.38 & $\mathbf{0 . 1 0}$ & 0.09 & $\mathbf{0 . 2 5}$ & 0.13 \\
\hline $\begin{array}{l}\text { Total } \mathrm{Na}^{+}(\text {Substrate } \\
\text { solution }+ \text { Dosed as } \mathrm{NaOH} \\
+ \text { Nutrients solution })\end{array}$ & $\mathrm{mM}$ & $\mathbf{5 8 . 4 5}$ & 8.9 & $\mathbf{7 8 . 9 2}$ & 19 & $\mathbf{6 2 . 0 5}$ & 8.3 & $\mathbf{7 5 . 1 7}$ & 10.54 \\
\hline
\end{tabular}




\section{B3. Quantification of soluble and bound extracellular biopolymers in solids}
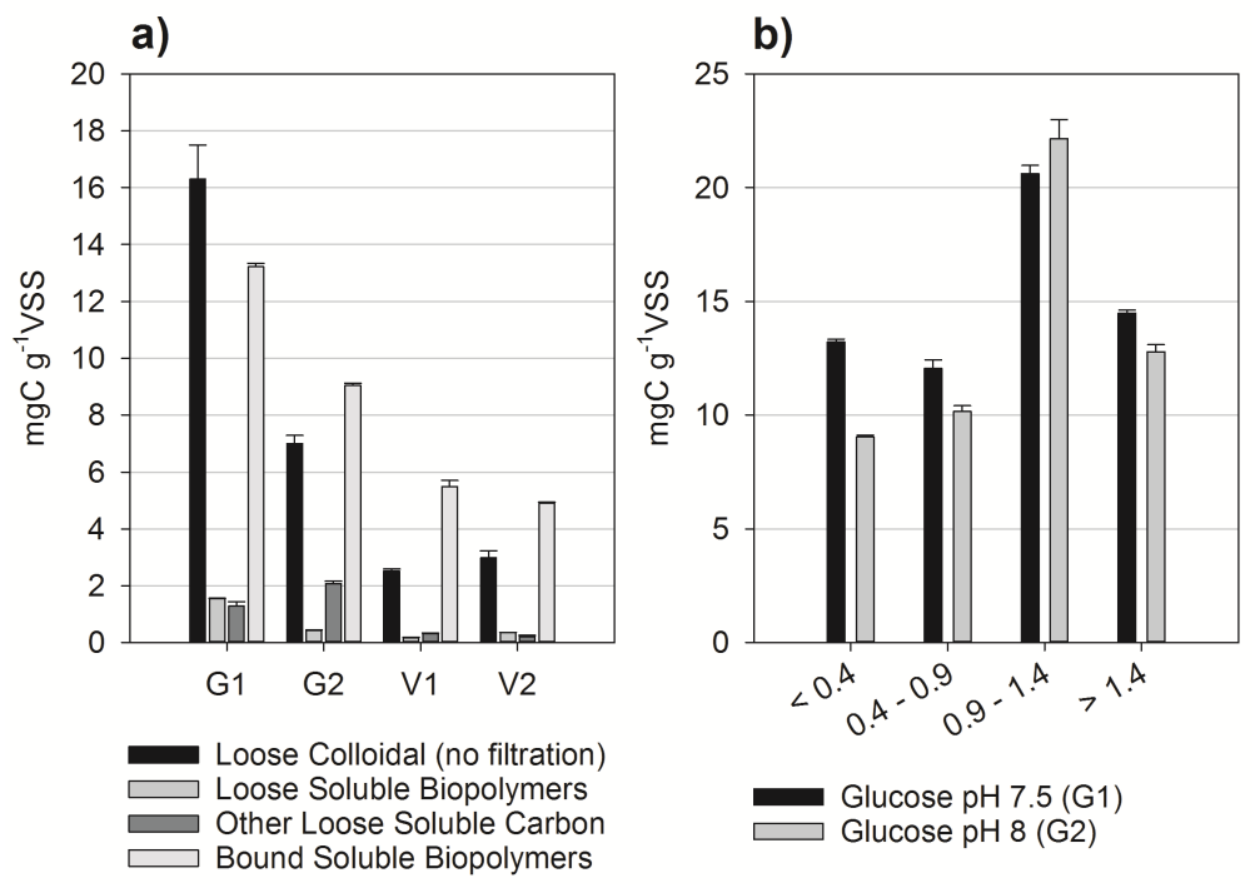

Figure B3.1 Quantification of loose colloidal organic carbon (DOC - TOC), and loose and bound soluble biopolymers for solids $<0.4 \mathrm{~mm}$ diameter from each reactor (a). Quantification of bound biopolymers for each particle size fraction in reactors G1 and G2 fed with glucose (b).

\section{Appendix C}

\section{C1. COMSOL model description}

Gas-lift reactors are widely applied in many processes due to their efficient and gentle mixing at low cost without any moving parts. However, a sophisticated and good working reactor is hard to design due to the complexity of the gas-liquid interactions. Computational fluid dynamics (CFD) is a helpful tool to predict the operation of the reactor. Commercial and free software have been used for different mathematical approaches in several studies. Most of the CFD models for pilot and industrial scale systems have used two-fluid Eulerian-Eulerian Reynolds-Averaged Navier-Stokes (RANS) method. The bubbly flow (bf) interface in COMSOL sets up a multiphase flow model of gas and liquid that suits a gas-lift reactor based on the Eulerian-Eulerian RANS method. Below is presented a brief description of the calculus 
flow used by COMSOL according to the CFD module user's guide for turbulent bubbly flow (COMSOL, 2010).

\section{Bubbly flow}

The bubbly flow interface in COMSOL solves for the liquid velocity, the gas volume fraction, pressure, and viscosity of a gas-liquid mixture. It is based on the two-fluid EulerEuler model. This macroscopic model treats the gas and liquid phase as interpenetrating media and is tracking the averaged concentration of each phase. Each phase has an individual velocity field, and their individual dynamics are described by a momentum balance equation and a continuity equation. The physics are based on fundamental theories of fluid dynamics. The assumptions made for this model are:

- The gas density is negligible compared to the liquid density.

- The two phases share the same pressure field.

- The balance between viscous drag and pressure forces determines the motion of the gas bubbles relative to the liquid.

These assumptions then allow taking the sum of the momentum equations of both phases to result in the momentum equation for the liquid velocity (eq. C1.1), a continuity equation (eq. C1.2), and a transport equation for the volume fraction of the gas phase (eq. C1.3) (COMSOL, 2010).

The momentum equation for the liquid velocity is:

$\phi_{l} \rho_{l} \frac{\partial u_{l}}{\partial t}+\phi_{l} \rho_{l} u_{l} \cdot \nabla u_{l}=-\nabla p+\nabla\left[\phi_{l}\left(\mu_{l}+\mu_{T}\right)\left(\nabla u_{l}+u_{l}^{T}-\frac{2}{3}\left(\nabla * u_{l}\right) I\right)\right]+\phi_{l} \rho_{l} g+F$

Equation $\mathrm{C} 1.1$

where the subscript $l$ classifies quantities related to the liquid phase, $\phi$ is the dimensionless phase volume fraction $\left(\mathrm{m}^{3} \mathrm{~m}^{-3}\right), \rho$ is the density $\left(\mathrm{kg} \mathrm{m}^{-3}\right), u$ is the velocity $\left(\mathrm{m} \mathrm{s}^{-1}\right), \mu$ is the dynamic viscosity ( $\mathrm{Pa} \mathrm{s}), \mu_{T}$ is the turbulent viscosity ( $\mathrm{Pa} \mathrm{s}$ ), and $F$ is any additional volume force $\left(\mathrm{N} \mathrm{m}^{-3}\right)$.

The continuity equation is given by:

$\frac{\partial}{\partial t}\left(\rho_{l} \phi_{l}+\rho_{g} \phi_{g}\right)+\nabla\left(\rho_{l} \phi_{l} u_{l}+\rho_{g} \phi_{g} u_{g}\right)=0$ Equation $\mathrm{C} 1.2$

where the subscript $g$ determines quantities associated to the gas phase. The gas density is calculated via the ideal gas law. 
The transport for the volume fraction of the gas phase is described by the following equation:

$\frac{\partial \rho_{g} \phi_{g}}{\partial t}+\nabla \cdot\left(\phi_{g} \rho_{g} u_{g}\right)=-m_{g l}$

Equation $\mathrm{C} 1.3$

where $m_{g l}$ is the mass transfer rate from gas to liquid $\left(\mathrm{kg} \mathrm{m}^{-3} \mathrm{~s}^{-1}\right)$.

The gas velocity $\left(u_{g}\right)$ in laminar flow can be described by eq. C1.4 and is the sum of the liquid $\left(u_{l}\right)$, the slip $\left(u_{\text {slip }}\right)$, and the drift $\left(u_{\text {drift }}\right)$ velocities. Where the slip velocity is the relative velocity between the phases and the drift velocity is the result of turbulences.

$u_{g}=u_{l}+u_{\text {slip }}+u_{\text {drift }} \quad$ Equation C1.4

For calculating the slip velocity, the pressure drag balance is used in this physics interface. For this approach, it is assumed that the pressure forces on a bubble are controlled by the viscous drag as described in eq. C1.5.

$\frac{3}{4} \frac{c_{d}}{d_{b}} \rho_{l}\left|u_{\text {slip }}\right| u_{\text {slip }}=-\nabla p$

Equation $\mathrm{C} 1.5$

where $d_{b}$ is the bubble diameter and $C_{d}$ the drag coefficient.

The bubble diameter is determined by setup conditions, such as gas inlet diameter. Since the bubble diameter is smaller than $2 \mathrm{~mm}$, the drag coefficient can be determined via the Hadamard-Rybczinski drag law as described in eq. C1.6.

$C_{d}=\frac{16}{R e_{b}}$

Equation C1.6

where the Reynolds number related to the bubble can be determined via eq. C1.7.

$R e_{b}=\frac{d_{b} \rho_{l}\left|u_{s l i p}\right|}{\eta_{l}}$

Equation $\mathrm{C} 1.7$

The drift velocity can be calculated via eq. C1.8 but depends on turbulent quantities presented further.

$$
u_{\text {drift }}=\frac{\mu_{T}}{\rho_{l}} \frac{\nabla \phi_{g}}{\phi_{g}}
$$




\section{Turbulence modeling}

In a gas-lift reactor, turbulences are induced by liquid streams and additionally by the gas bubbles motion. The bubbly flow interface uses the $k-\varepsilon$ turbulence model accounting for both turbulence productions (COMSOL, 2010).

This model is based on the turbulent kinetic energy, $k\left(\mathrm{~m}^{2} \mathrm{~s}^{-2}\right)$ and the dissipation rate of turbulent energy, $\varepsilon\left(\mathrm{m} \mathrm{s}^{-3}\right)$. Coming back to the turbulent viscosity this gives:

$\mu_{T}=\rho_{l} C_{\mu} \frac{k^{2}}{\varepsilon}$

Equation C1.9

where $C_{\mu}$ is a model constant which is depending on the individual setup.

To solve for the turbulent kinetic energy $(k)$, its transport equation is needed and is given in eq. C1.10.

$\rho_{l} \frac{\partial k}{\partial t}+\rho_{l} u_{l} \cdot \nabla k=\nabla\left[\left(\mu+\frac{\mu_{T}}{\sigma_{k}}\right) \nabla k\right]+P_{k}-\rho_{l} \varepsilon+S_{k} \quad$ Equation $\mathrm{C} 1.10$

where $P_{k}$ is the production term calculated by eq. $\mathrm{C} 1.11, \varepsilon$ is the dissipation rate of the turbulent energy calculated by eq. $\mathrm{C} 1.12$, and $S_{k}$ represents the turbulence induced by bubbles, which is calculated through eq. $\mathrm{C} 1.13$.

$P_{k}=\mu_{T}\left(\nabla u_{l}:\left(\nabla u_{l}+\left(\nabla u_{l}\right)^{T}\right)-\frac{2}{3}\left(\nabla \cdot u_{l}\right)^{2}\right)-\frac{2}{3} \rho k \nabla \cdot u_{l} \quad$ Equation C1.11

$\rho_{l} \frac{\partial \varepsilon}{\partial t} \rho_{l} u_{l} \cdot \nabla \varepsilon=\nabla \cdot\left[\left(\mu+\frac{\mu_{T}}{\sigma_{\varepsilon}}\right) \nabla \varepsilon\right]+C_{\varepsilon l} \frac{\varepsilon}{k} C_{\varepsilon 1} P_{k}-\rho_{l} C_{\varepsilon 2} \frac{\varepsilon^{2}}{k}+C_{\varepsilon} S_{k} \frac{\varepsilon}{k}$

Equation $\mathrm{C} 1.12$

$S_{k}=-C_{k} \phi_{g} \nabla p u_{s l i p}$

Equation $\mathrm{C} 1.13$

The model parameters $C_{\varepsilon 1}, C_{\varepsilon 2}, \sigma_{k}$, and $\sigma_{\varepsilon}$ are as $C_{\mu}$ dependent on the individual setup. However, certain ranges are suitable for the bubbly flow interface which are retrieved empirically. The typical values suiting a gas-lift reactor are presented in Table C1.1. 


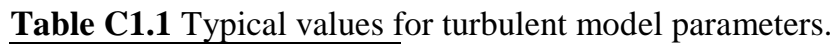

\begin{tabular}{cl}
\hline Constant & Value \\
\hline$C_{\mu}$ & 0.09 \\
$C_{\varepsilon 1}$ & 1.44 \\
$C_{\varepsilon 2}$ & 1.92 \\
$\sigma_{k}$ & 1.0 \\
$\sigma_{\varepsilon}$ & 1.3 \\
\hline
\end{tabular}

COMSOL solves all aforementioned equations for each area defined by the mesh. Therefore, the mesh is defining the accuracy of the model (Figure C1.1).

a)

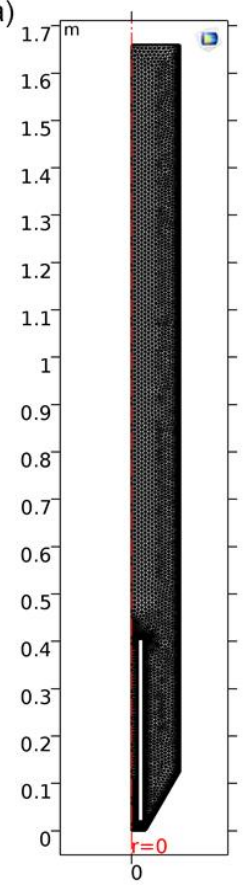

b)

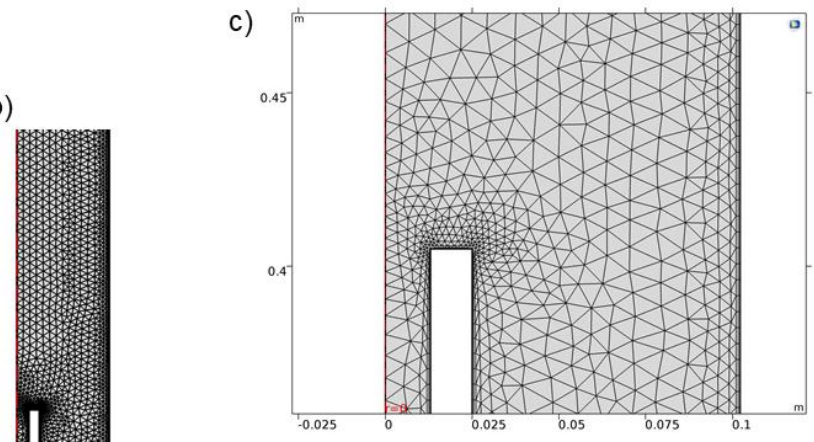

c)

d)

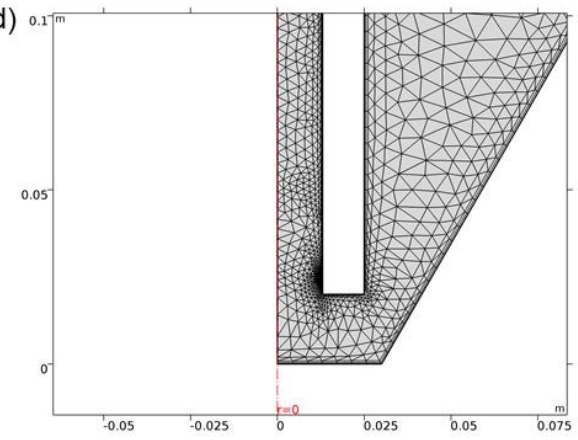

Figure C1.1 Mesh scheme assumed for the model reactor (a). Zoom in for the mesh distribution in the entire riser (b), top (c), and bottom (d). 


\section{C2. Influent and effluent characterization}

a)

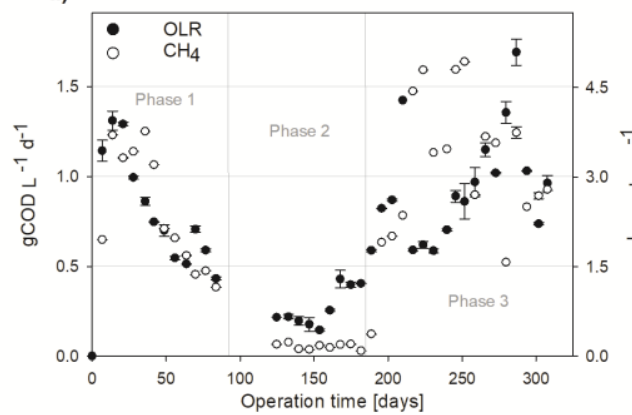

c)

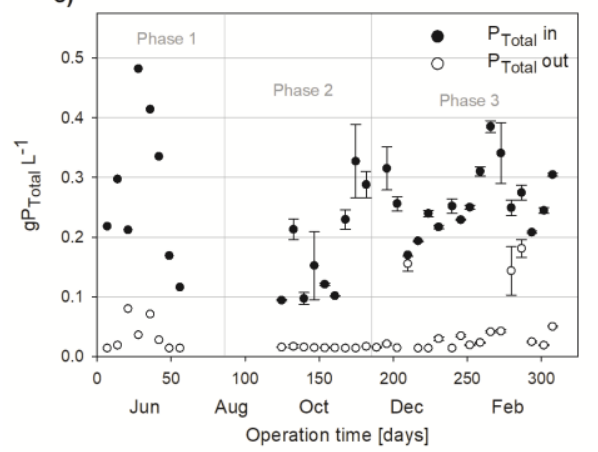

b)

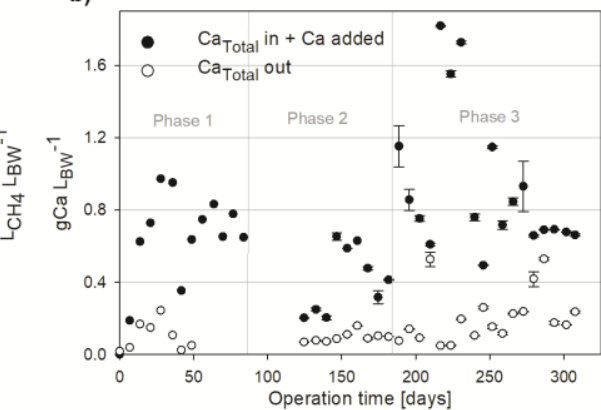

d)

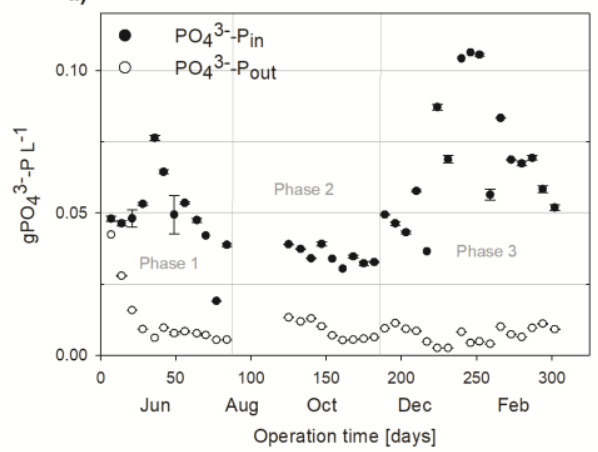

Figure C2.1 OLR and methane production during the entire operation period (300 days) (a). Influent plus added and effluent concentrations of calcium (b). Influent and effluent concentrations of total $\mathrm{P}$ (c). Influent and effluent concentrations of $\mathrm{PO}_{4}{ }^{3-}(\mathrm{d})$. 


\section{C3. PSD of sludge bed over time}
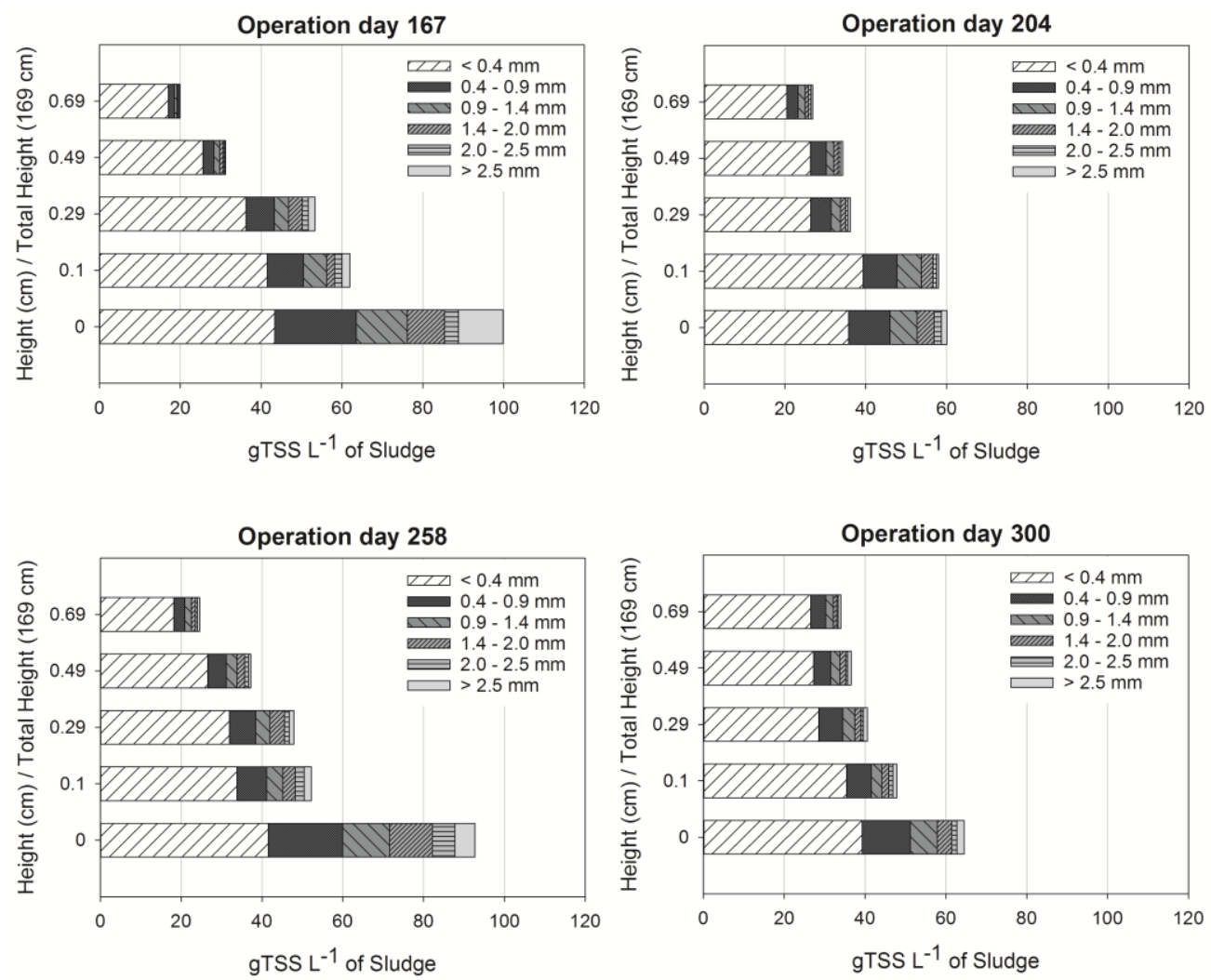

Figure C3.1 Vertical distribution of TSS concentrations categorized in six size fractions (< $0.4 \mathrm{~mm}, 0.4-0.9 \mathrm{~mm}, 0.9-1.4 \mathrm{~mm}, 1.4-2 \mathrm{~mm}, 2-2.5 \mathrm{~mm}$, and > $2.5 \mathrm{~mm}$ ) from sludge taken from the UASB-GLR (45 L) on operation days 167, 204, 258, and 300. 
C4. Elemental composition for each size fraction from the bottom of the reactor over time
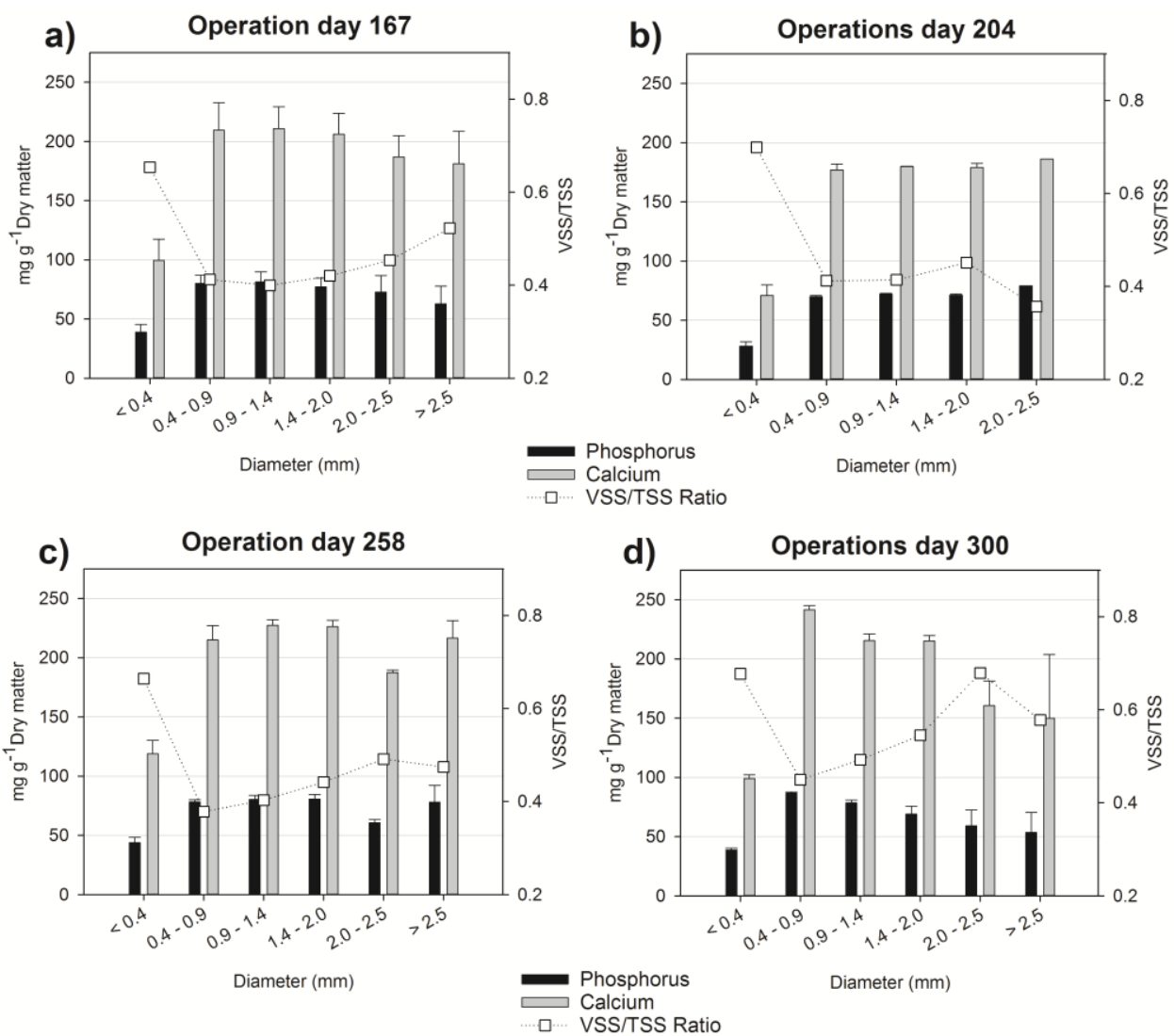

Figure C4.1 $\mathrm{P}$ and Ca contents and VSS/TSS ratio of different sized particles from the bottom of the UASB-GL reactor at operation days 167 (a), 204 (b), 258 (c), and 300 (d). 


\section{Appendix D}

\section{D1. Scheme for separation}

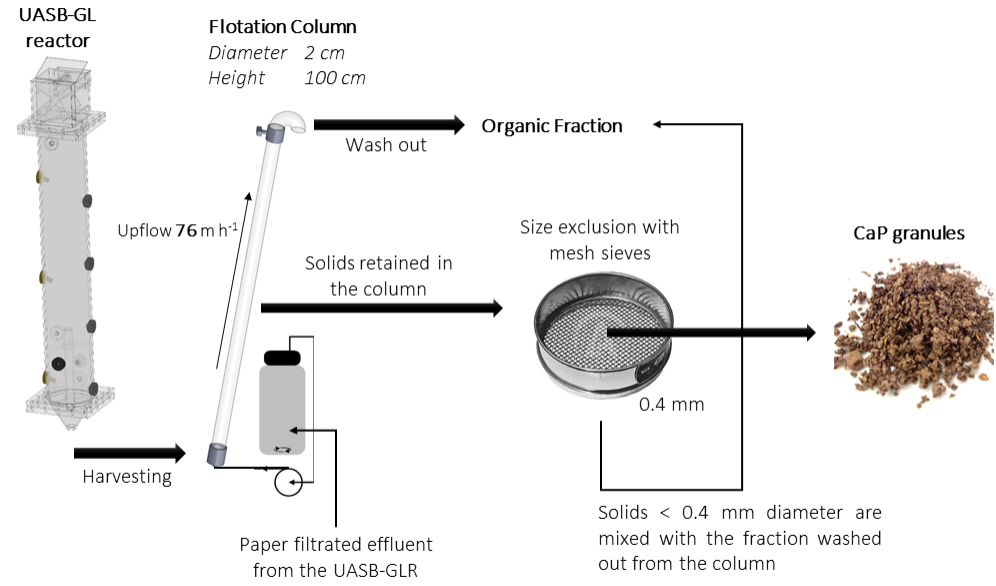

Figure D1.1 Schematic representation of the process for separation of $\mathrm{CaP}$ granules from the organic fraction. 


\section{D2. Organic Micropollutants}

Table D2.1 Micropollutants analyzed and respective code and limit of detected (LOQ)

\begin{tabular}{|c|c|c|c|c|c|}
\hline Name & Code & $\begin{array}{l}\text { LOQ } \\
\left(\mathrm{ng} \mathrm{g}^{-1}\right)\end{array}$ & Name & Code & $\begin{array}{l}\text { LOQ } \\
\left(\operatorname{ng~g}^{-1}\right)\end{array}$ \\
\hline Acesulfame & ACSUL & $<5$ & Ketoprofen & KTPF & $<2$ \\
\hline Amoxicillin & AMOX & $<2$ & Lincomycin & LINCOM & $<1$ \\
\hline Ampicillin & AMP & $<2$ & MCPA & MCPA & $<10$ \\
\hline Aspirin & ASA & $<20$ & Mecoprop & MCPP & $<10$ \\
\hline Azithromycin & AZI & $<2$ & Metformin & METF & $<5$ \\
\hline Benzalkonium Chloride & $\mathrm{BaC} 12$ & $<2$ & Methylparaben & MePB & $<10$ \\
\hline $\mathrm{C} 12$ & & & Metoprolol & METPL & $<2$ \\
\hline Benzalkonium Chloride & $\mathrm{BaC} 14$ & $<2$ & Naproxen & NAPR & $<2$ \\
\hline $\mathrm{C} 14$ & & & Ofloxacin & OFX & $<0.5$ \\
\hline Benzylparaben & $\mathrm{BzPB}$ & $<5$ & Oxazepam & OXA & $<1$ \\
\hline Butylparaben & $\mathrm{BuPB}$ & $<5$ & Oxytetracyclin & OTETR & $<1$ \\
\hline Caffeine & $\mathrm{CAF}$ & $<1$ & Paracetamol & PARA & $<10$ \\
\hline Carbamazepine & $\mathrm{CBZ}$ & $<0.2$ & Penicillin G & PENG & $<1$ \\
\hline Cefotaxime & CFT & $<5$ & Penicillin V & PENV & $<2$ \\
\hline Cetirizine & CETRZ & $<20$ & Propylparaben & PrPB & $<5$ \\
\hline Ciprofloxacin & CFX & $<0.5$ & Sucralose & SUCRAL & $<5$ \\
\hline Clarithromycin & CLAR & $<0.2$ & Sulfachloropyridazine & SUCLOP & $<0.5$ \\
\hline Clindamycin & $\mathrm{CM}$ & $<0.5$ & Sulfadoxin & SUDOX & $<0.5$ \\
\hline Diclofenac & DFN & $<0.5$ & Sulfamethazine & SULFAM & $<1$ \\
\hline Diethyltoluamide & DEET & $<1$ & Sulfapyridine & SULPYR & $<1$ \\
\hline Dimetridazole & DM & $<5$ & Sulfomethoxazole & SMO & $<1$ \\
\hline Doxicycline & DOX & $<2$ & Tetracycline & TETR & $<1$ \\
\hline Erythromycin & ERYT & $<5$ & Tilmicosin & TILMIC & $<5$ \\
\hline Ethylparaben & EtPB & $<10$ & Tilosin & TYLOS & $<1$ \\
\hline Flumequine & FLUMEQ & $<1$ & Triclocarban & TCC & $<1$ \\
\hline Gabapentine & GAPE & $<0.5$ & Triclosan & TCS & $<20$ \\
\hline $\begin{array}{l}\text { Hydrochlorothiazide } \\
\text { Ibuprofen }\end{array}$ & $\begin{array}{l}\text { HCTZ } \\
\text { IBPF }\end{array}$ & $\begin{array}{l}<50 \\
<20\end{array}$ & Trimethoprim & TRIM & $<2$ \\
\hline
\end{tabular}


Table D2.2 Standard solution used for recovery and calibration dilutions D1, D2, D3, D4, D5 corresponding to 0, 20, 40, 80, 160 and 320 times dilution, respectively.

\begin{tabular}{|c|c|c|c|c|c|c|c|}
\hline Code & Standard $\mu \mathrm{g} / \mathrm{ml}$ & $\mathrm{D} 1 \mu \mathrm{g} / \mathrm{ml}$ & $\mathrm{D} 2 \mu \mathrm{g} / \mathrm{ml}$ & $\mathrm{D} 3 \mu \mathrm{g} / \mathrm{ml}$ & $\mathrm{D} 4 \mu \mathrm{g} / \mathrm{ml}$ & $\mathrm{D} 4 \mu \mathrm{g} / \mathrm{ml}$ & D5 $\mu \mathrm{g} / \mathrm{ml}$ \\
\hline ACSUL & 0.259 & 0.0 & 5.2 & 10.4 & 20.7 & 41.4 & 82.9 \\
\hline AMOX & 0.133 & 0.0 & 2.7 & 5.3 & 10.7 & 21.3 & 42.7 \\
\hline AMP & 0.133 & 0.0 & 2.7 & 5.3 & 10.7 & 21.3 & 42.7 \\
\hline ASA & 0.129 & 0.0 & 2.6 & 5.2 & 10.3 & 20.6 & 41.2 \\
\hline AZI & 0.133 & 0.0 & 2.7 & 5.3 & 10.7 & 21.3 & 42.7 \\
\hline BAC (75\%C12,25\% C14) & 0.133 & 0.0 & 2.7 & 5.3 & 10.7 & 21.3 & 42.6 \\
\hline BuPB & 0.127 & 0.0 & 2.5 & 5.1 & 10.1 & 20.3 & 40.5 \\
\hline $\mathrm{BzPB}$ & 0.131 & 0.0 & 2.6 & 5.2 & 10.4 & 20.9 & 41.8 \\
\hline CAF & 0.132 & 0.0 & 2.6 & 5.3 & 10.6 & 21.1 & 42.2 \\
\hline $\mathrm{CBZ}$ & 0.133 & 0.0 & 2.7 & 5.3 & 10.7 & 21.3 & 42.6 \\
\hline CETRZ & 0.133 & 0.0 & 2.7 & 5.3 & 10.7 & 21.3 & 42.6 \\
\hline CFT & 0.133 & 0.0 & 2.7 & 5.3 & 10.7 & 21.3 & 42.7 \\
\hline CFX & 0.133 & 0.0 & 2.7 & 5.3 & 10.7 & 21.3 & 42.7 \\
\hline CLAR & 0.133 & 0.0 & 2.7 & 5.3 & 10.7 & 21.3 & 42.7 \\
\hline $\mathrm{CM}$ & 0.133 & 0.0 & 2.7 & 5.3 & 10.7 & 21.3 & 42.7 \\
\hline DEET & 0.132 & 0.0 & 2.6 & 5.3 & 10.6 & 21.1 & 42.2 \\
\hline DFN & 0.131 & 0.0 & 2.6 & 5.2 & 10.5 & 21.0 & 41.9 \\
\hline DM & 0.133 & 0.0 & 2.7 & 5.3 & 10.7 & 21.3 & 42.6 \\
\hline
\end{tabular}




\begin{tabular}{|c|c|c|c|c|c|c|c|}
\hline Code & Standard $\mu \mathrm{g} / \mathrm{ml}$ & $\mathrm{D} 1 \mu \mathrm{g} / \mathrm{ml}$ & $\mathrm{D} 2 \mu \mathrm{g} / \mathrm{ml}$ & $\mathrm{D} 3 \mu \mathrm{g} / \mathrm{ml}$ & $\mathrm{D} 4 \mu \mathrm{g} / \mathrm{ml}$ & $\mathrm{D} 4 \mu \mathrm{g} / \mathrm{ml}$ & D5 $\mu \mathrm{g} / \mathrm{ml}$ \\
\hline DOX & 0.134 & 0.0 & 2.7 & 5.3 & 10.7 & 21.4 & 42.7 \\
\hline ERYT & 0.133 & 0.0 & 2.7 & 5.3 & 10.7 & 21.3 & 42.6 \\
\hline EtPB & 0.126 & 0.0 & 2.5 & 5.0 & 10.1 & 20.2 & 40.3 \\
\hline FLUMEQ & 0.133 & 0.0 & 2.7 & 5.3 & 10.7 & 21.3 & 42.7 \\
\hline GAPE & 0.133 & 0.0 & 2.7 & 5.3 & 10.7 & 21.3 & 42.7 \\
\hline HCTZ & 0.128 & 0.0 & 2.6 & 5.1 & 10.2 & 20.5 & 41.0 \\
\hline IBPF & 0.129 & 0.0 & 2.6 & 5.2 & 10.3 & 20.7 & 41.3 \\
\hline KTPF & 0.126 & 0.0 & 2.5 & 5.1 & 10.1 & 20.2 & 40.4 \\
\hline LINCOM & 0.133 & 0.0 & 2.7 & 5.3 & 10.7 & 21.3 & 42.7 \\
\hline MCPA & 0.127 & 0.0 & 2.5 & 5.1 & 10.2 & 20.3 & 40.7 \\
\hline MCPP & 0.133 & 0.0 & 2.7 & 5.3 & 10.6 & 21.3 & 42.6 \\
\hline $\mathrm{MePB}$ & 0.129 & 0.0 & 2.6 & 5.2 & 10.3 & 20.6 & 41.2 \\
\hline METF & 0.133 & 0.0 & 2.7 & 5.3 & 10.7 & 21.3 & 42.6 \\
\hline MTPL & 0.132 & 0.0 & 2.6 & 5.3 & 10.6 & 21.1 & 42.3 \\
\hline NAPR & 0.131 & 0.0 & 2.6 & 5.2 & 10.5 & 21.0 & 41.9 \\
\hline OFX & 0.133 & 0.0 & 2.7 & 5.3 & 10.7 & 21.3 & 42.7 \\
\hline OTETR & 0.134 & 0.0 & 2.7 & 5.3 & 10.7 & 21.4 & 42.7 \\
\hline OXA & 0.133 & 0.0 & 2.7 & 5.3 & 10.7 & 21.3 & 42.6 \\
\hline PARA & 0.132 & 0.0 & 2.6 & 5.3 & 10.6 & 21.2 & 42.4 \\
\hline
\end{tabular}




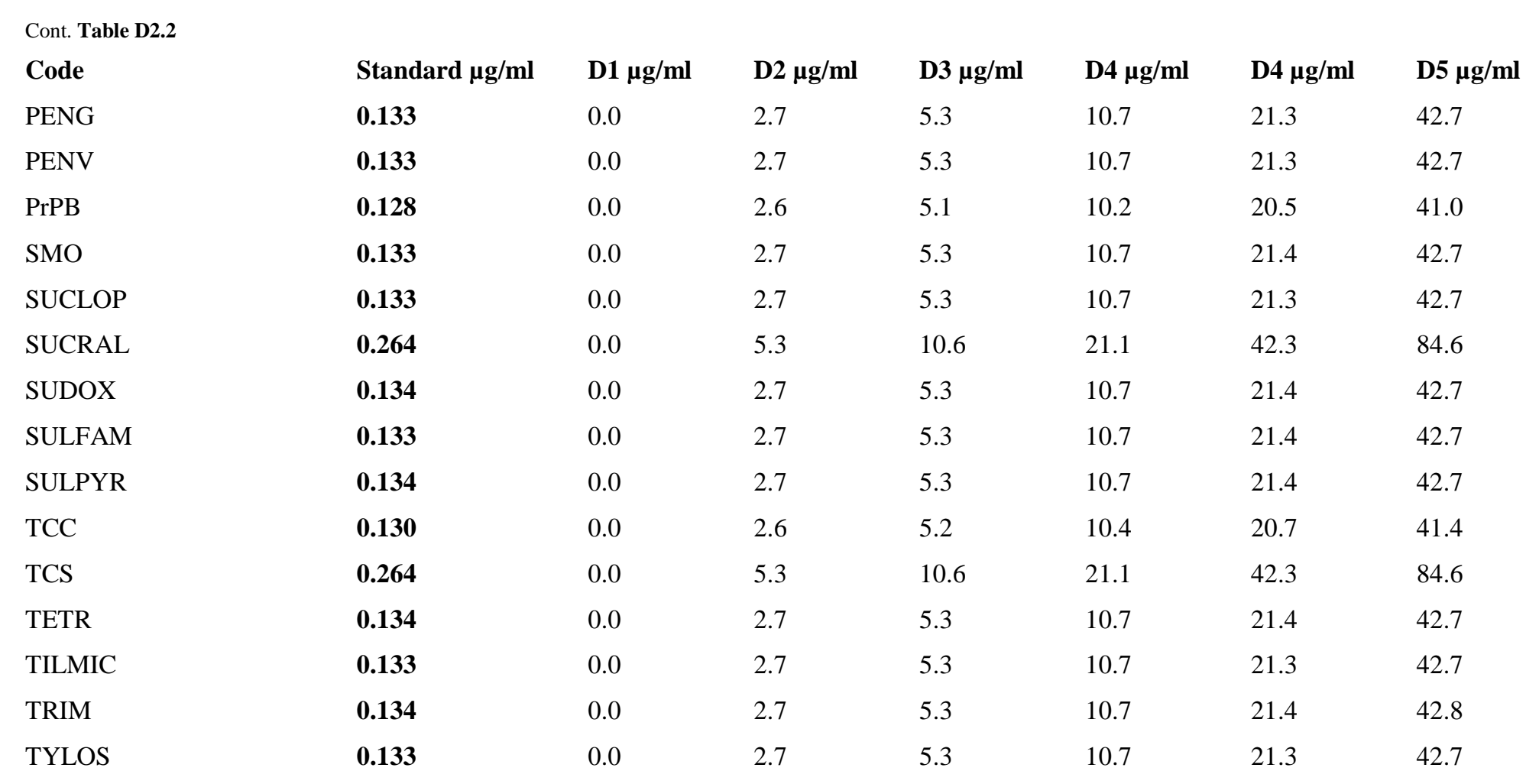


Table D2.3 Internal standard solution and calibration dilutions D1, D2, D3, D4, D5 corresponding to 0, 20, 40, 80, 160 and 320 times dilution, respectively.

$\begin{array}{llllllll}\text { Code } & \begin{array}{l}\text { Internal } \\ \text { Standard } \boldsymbol{\mu g} / \mathbf{m l}\end{array} & \mathbf{D} 1 \boldsymbol{\mu g} / \mathbf{m l} & \mathbf{D 2} \boldsymbol{\mu g} / \mathbf{m l} & \mathbf{D 3} \boldsymbol{\mu g} / \mathbf{m l} & \mathbf{D 4} \boldsymbol{\mu g} / \mathbf{m l} & \mathbf{D 4} \boldsymbol{\mu g} / \mathbf{m l} & \mathbf{D 5} \boldsymbol{\mu g} / \mathbf{m l} \\ \text { TRIM-D9 } & \mathbf{0 . 3 6 6} & 18.3 & 18.3 & 18.3 & 18.3 & 18.3 & 18.3 \\ \text { DIA } & \mathbf{0 . 3 6 6} & 18.3 & 18.3 & 18.3 & 18.3 & 18.3 & 18.3 \\ \text { FNPF } & \mathbf{1 . 8 2 7} & 91.3 & 91.3 & 91.3 & 91.3 & 91.3 & 91.3 \\ \text { AT-D7 } & \mathbf{0 . 3 6 6} & 18.3 & 18.3 & 18.3 & 18.3 & 18.3 & 18.3 \\ \text { CFX-D8 } & \mathbf{0 . 3 6 6} & 18.3 & 18.3 & 18.3 & 18.3 & 18.3 & 18.3 \\ \text { SUDOX-D3 } & \mathbf{0 . 3 6 6} & 18.3 & 18.3 & 18.3 & 18.3 & 18.3 & 18.3\end{array}$


Table D2.4 Complete list of results obtained for each sample of organic fraction and CaP granules and also the blank measurement.

\begin{tabular}{|c|c|c|c|c|c|c|c|c|c|c|c|c|c|}
\hline & & & 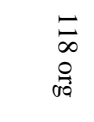 & $\begin{array}{l}\vec{a} \\
\stackrel{0}{0} \\
\text { da }\end{array}$ & 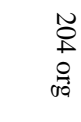 & 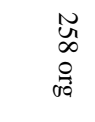 & 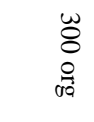 & 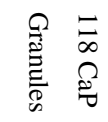 & 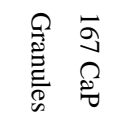 & 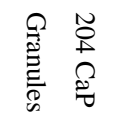 & 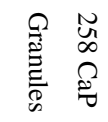 & 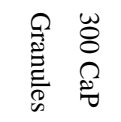 & $\stackrel{\square}{\underline{\underline{V}}}$ \\
\hline Amoxicillin & AMOX & $\mathrm{ng} / \mathrm{g}$ & $<2$ & $<2$ & $<2$ & $<2$ & $<2$ & $<2$ & $<2$ & $<2$ & $<2$ & $<2$ & $<2$ \\
\hline Paracetamol & PARA & $\mathrm{ng} / \mathrm{g}$ & 12 & 11 & 12 & 26 & 17 & $<10$ & 21 & 39 & 24 & 13 & $<10$ \\
\hline Trimethoprim & TRIM & $\mathrm{ng} / \mathrm{g}$ & $<2$ & $<2$ & $<2$ & $<2$ & $<2$ & $<2$ & $<2$ & $<2$ & $<2$ & $<2$ & $<2$ \\
\hline Sucralose & SUCRAL & $\mathrm{ng} / \mathrm{g}$ & 163 & 156 & 177 & 138 & 178 & 80 & 119 & 108 & 116 & 108 & $<5$ \\
\hline Sulfamethazine & SULFAM & $\mathrm{ng} / \mathrm{g}$ & $<1$ & $<1$ & $<1$ & $<1$ & $<1$ & $<1$ & $<1$ & $<1$ & $<1$ & $<1$ & $<1$ \\
\hline Azithromycin & AZI & $\mathrm{ng} / \mathrm{g}$ & 596 & 635 & 1263 & 1283 & 886 & 64 & 170 & 391 & 181 & 184 & $<2$ \\
\hline Clindamycin & $\mathrm{CM}$ & $\mathrm{ng} / \mathrm{g}$ & 0.7 & 0.6 & $<0.5$ & $<0.5$ & $<0.5$ & $<0.5$ & 0.6 & 0.7 & $<0.5$ & $<0.5$ & $<0.5$ \\
\hline Sulfachloropyridazine & SUCLOP & $\mathrm{ng} / \mathrm{g}$ & $<0.5$ & $<0.5$ & $<0.5$ & $<0.5$ & $<0.5$ & $<0.5$ & $<0.5$ & $<0.5$ & $<0.5$ & $<0.5$ & $<0.5$ \\
\hline Sulfadoxin & SUDOX & $\mathrm{ng} / \mathrm{g}$ & $<0.5$ & $<0.5$ & $<0.5$ & $<0.5$ & $<0.5$ & $<0.5$ & $<0.5$ & $<0.5$ & $<0.5$ & $<0.5$ & $<0.5$ \\
\hline Sulfomethoxazole & SMO & $\mathrm{ng} / \mathrm{g}$ & $<1$ & $<1$ & $<1$ & $<1$ & $<1$ & $<1$ & $<1$ & $<1$ & $<1$ & $<1$ & $<1$ \\
\hline Tilosin & TYLOS & $\mathrm{ng} / \mathrm{g}$ & $<1$ & $<1$ & $<1$ & $<1$ & $<1$ & $<1$ & $<1$ & $<1$ & $<1$ & $<1$ & $<1$ \\
\hline Penicillin G & PENG & $\mathrm{ng} / \mathrm{g}$ & $<1$ & $<1$ & $<1$ & $<1$ & $<1$ & $<1$ & $<1$ & $<1$ & $<1$ & $<1$ & $<1$ \\
\hline Cetirizine & CETRZ & $\mathrm{ng} / \mathrm{g}$ & 4371 & 4394 & 4058 & 4020 & 4085 & 2464 & 2764 & 2731 & 2336 & 2216 & $<20$ \\
\hline Penicillin V & PENV & $\mathrm{ng} / \mathrm{g}$ & $<2$ & $<2$ & $<2$ & $<2$ & $<2$ & $<2$ & $<2$ & $<2$ & $<2$ & $<2$ & $<2$ \\
\hline Clarithromycin & CLAR & $\mathrm{ng} / \mathrm{g}$ & 0.9 & 0.3 & $<0.2$ & $<0.2$ & $<0.2$ & 0.3 & 0.2 & $<0.2$ & $<0.2$ & $<0.2$ & $<0.2$ \\
\hline Carbamazepine & CBZ & $\mathrm{ng} / \mathrm{g}$ & 17.0 & 7.3 & 6.3 & 3.8 & 2.8 & 8.7 & 3.9 & 4.3 & 3.1 & 0.9 & $<0.2$ \\
\hline Ketoprofen & KTPF & $\mathrm{ng} / \mathrm{g}$ & $<2$ & $<2$ & $<2$ & $<2$ & $<2$ & $<2$ & $<2$ & $<2$ & $<2$ & $<2$ & $<2$ \\
\hline Naproxen & NAPR & $\mathrm{ng} / \mathrm{g}$ & $<2$ & $<2$ & $<2$ & $<2$ & $<2$ & $<2$ & $<2$ & $<2$ & $<2$ & $<2$ & $<2$ \\
\hline Ibuprofen & IBPF & $\mathrm{ng} / \mathrm{g}$ & 89 & 52 & 186 & 137 & 189 & $<20$ & $<20$ & 56 & $<20$ & $<20$ & $<20$ \\
\hline Metformin & METF & $\mathrm{ng} / \mathrm{g}$ & 62 & 102 & 53 & 61 & 74 & 34 & 61 & 65 & 90 & 64 & $<5$ \\
\hline
\end{tabular}




\begin{tabular}{|c|c|c|c|c|c|c|c|c|c|c|c|c|c|}
\hline Cont. Table D2.4 & & & $\begin{array}{c}\varpi \\
\stackrel{\infty}{\infty} \\
\stackrel{\sigma}{\infty}\end{array}$ & $\begin{array}{l}\vec{a} \\
\stackrel{9}{a}\end{array}$ & 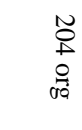 & $\begin{array}{l}N_{0} \\
\infty \\
\infty \\
0 \\
00\end{array}$ & $\begin{array}{l}\omega \\
8 \\
\varrho \\
0 \\
0\end{array}$ & $\stackrel{9}{\stackrel{0}{E}}$ & 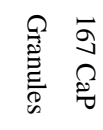 & 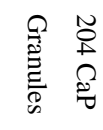 & 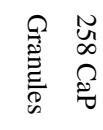 & 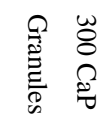 & $\stackrel{\square}{\mathscr{\Xi}}$ \\
\hline Dimetridazole & DM & $\mathrm{ng} / \mathrm{g}$ & $<5$ & $<5$ & $<5$ & $<5$ & $<5$ & $<5$ & $<5$ & $<5$ & $<5$ & $<5$ & $<5$ \\
\hline Gabapentine & GAPE & $\mathrm{ng} / \mathrm{g}$ & 3.3 & 1.7 & 1.1 & 1.3 & 0.5 & 1.4 & 1.7 & 4.9 & 2.7 & 1.2 & $<0.5$ \\
\hline Sulfapyridine & SULPYR & $\mathrm{ng} / \mathrm{g}$ & 3.4 & 2.8 & 2.3 & 1.7 & 1.2 & $<1$ & $<1$ & 1.3 & $<1$ & $<1$ & $<1$ \\
\hline Lincomycin & LINCOM & $\mathrm{ng} / \mathrm{g}$ & $<1$ & $<1$ & $<1$ & $<1$ & $<1$ & $<1$ & $<1$ & $<1$ & $<1$ & $<1$ & $<1$ \\
\hline Caffeine & $\mathrm{CAF}$ & $\mathrm{ng} / \mathrm{g}$ & 23.2 & 38.7 & 11.3 & 18.0 & 4.3 & 8.9 & 21.1 & 15.3 & 5.6 & 15.1 & $<1$ \\
\hline Ampicillin & AMP & $\mathrm{ng} / \mathrm{g}$ & $<2$ & $<2$ & $<2$ & $<2$ & $<2$ & $<2$ & $<2$ & $<2$ & $<2$ & $<2$ & $<2$ \\
\hline Ofloxacin & OFX & $\mathrm{ng} / \mathrm{g}$ & 0.8 & 2.2 & 1.5 & 1.5 & $<0.5$ & 5.5 & 4.8 & 3.7 & 1.5 & 0.5 & $<0.5$ \\
\hline Ciprofloxacin & CFX & $\mathrm{ng} / \mathrm{g}$ & 599.3 & 439.7 & 352.3 & 268.2 & 208.8 & 577.2 & 411.2 & 369.3 & 201.6 & 203.9 & $<0.5$ \\
\hline Oxytetracyclin & OTETR & $\mathrm{ng} / \mathrm{g}$ & $<1$ & 2.1 & 1.9 & $<1$ & $<1$ & 1.5 & 1.4 & 2.4 & 1.7 & 1.3 & $<1$ \\
\hline Cefotaxime & CFT & $\mathrm{ng} / \mathrm{g}$ & $<5$ & $<5$ & $<5$ & $<5$ & $<5$ & $<5$ & $<5$ & $<5$ & $<5$ & $<5$ & $<5$ \\
\hline Tetracycline & TETR & $\mathrm{ng} / \mathrm{g}$ & 20.2 & 12.7 & 10.5 & 6.2 & 9.8 & 77.6 & 29.9 & 14.1 & 11.5 & 9.2 & $<1$ \\
\hline Metoprolol & METPL & $\mathrm{ng} / \mathrm{g}$ & 123 & 138 & 141 & 121 & 186 & 35 & 41 & 36 & 36 & 50 & $<2$ \\
\hline Tilmicosin & TILMIC & $\mathrm{ng} / \mathrm{g}$ & $<5$ & $<5$ & $<5$ & $<5$ & $<5$ & $<5$ & $<5$ & $<5$ & $<5$ & $<5$ & $<5$ \\
\hline Doxicycline & DOX & $\mathrm{ng} / \mathrm{g}$ & 422 & 407 & 324 & 314 & 415 & 501 & 436 & 440 & 447 & 477 & $<2$ \\
\hline Erythromycin & ERYT & $\mathrm{ng} / \mathrm{g}$ & $<5$ & $<5$ & $<5$ & $<5$ & $<5$ & $<5$ & $<5$ & $<5$ & $<5$ & $<5$ & $<5$ \\
\hline Oxazepam & OXA & $\mathrm{ng} / \mathrm{g}$ & 540 & 601 & 514 & 491 & 597 & 190 & 215 & 264 & 232 & 194 & $<1$ \\
\hline Flumequine & FLUMEQ & $\mathrm{ng} / \mathrm{g}$ & $<1$ & $<1$ & $<1$ & $<1$ & $<1$ & $<1$ & $<1$ & $<1$ & $<1$ & $<1$ & $<1$ \\
\hline Diethyltoluamide & DEET & $\mathrm{ng} / \mathrm{g}$ & $<1$ & $<1$ & $<1$ & $<1$ & $<1$ & $<1$ & $<1$ & $<1$ & $<1$ & $<1$ & $<1$ \\
\hline Benzalkonium Chloride C12 & $\mathrm{BaC} 12$ & $\mathrm{ng} / \mathrm{g}$ & 212 & 114 & 168 & 159 & 150 & 47 & 55 & 58 & 27 & 32 & $<2$ \\
\hline Diclofenac & DFN & $\mathrm{ng} / \mathrm{g}$ & 6.4 & 6.1 & 8.8 & 8.5 & 4.6 & 3.9 & 7.4 & 9.8 & 11.7 & 5.2 & $<0.5$ \\
\hline Benzalkonium Chloride C14 & $\mathrm{BaC} 14$ & $\mathrm{ng} / \mathrm{g}$ & 21 & 14 & 16 & 13 & 16 & 4 & 5 & 7 & 2 & $<2$ & $<2$ \\
\hline Acesulfame & ACSUL & $\mathrm{ng} / \mathrm{g}$ & 1746 & 835 & 3196 & 1374 & 2646 & 179 & 370 & 293 & 299 & 325 & $<5$ \\
\hline
\end{tabular}




\begin{tabular}{|c|c|c|c|c|c|c|c|c|c|c|c|c|c|}
\hline Cont. Table D2.4 & & & $\begin{array}{l}\varpi \\
\infty \\
\stackrel{0}{\infty a}\end{array}$ & 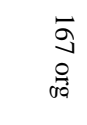 & 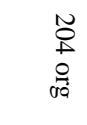 & $\begin{array}{l}N \\
\tilde{L} \\
\infty \\
0 \\
00\end{array}$ & $\begin{array}{l}\omega \\
8 \\
8 \\
0 \\
0\end{array}$ & $\stackrel{\cong}{\stackrel{\Xi}{E}}$ & 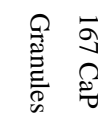 & 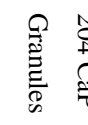 & 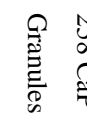 & 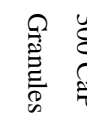 & $\underset{\pi}{2}$ \\
\hline Hydrochlorothiazide & HCTZ & $\mathrm{ng} / \mathrm{g}$ & 88 & 66 & 82 & 93 & 115 & $<50$ & $<50$ & $<50$ & $<50$ & $<50$ & $<50$ \\
\hline MCPA & MCPA & $\mathrm{ng} / \mathrm{g}$ & $<10$ & $<10$ & $<10$ & $<10$ & $<10$ & $<10$ & $<10$ & $<10$ & $<10$ & $<10$ & $<10$ \\
\hline Methylparaben & $\mathrm{MePB}$ & $\mathrm{ng} / \mathrm{g}$ & $<10$ & $<10$ & 12 & $<10$ & $<10$ & $<10$ & $<10$ & 20 & $<10$ & $<10$ & $<10$ \\
\hline Mecoprop & MCPP & $\mathrm{ng} / \mathrm{g}$ & $<10$ & $<10$ & $<10$ & $<10$ & $<10$ & $<10$ & $<10$ & $<10$ & $<10$ & $<10$ & $<10$ \\
\hline Ethylparaben & EtPB & $\mathrm{ng} / \mathrm{g}$ & $<10$ & $<10$ & $<10$ & $<10$ & $<10$ & $<10$ & $<10$ & $<10$ & $<10$ & $<10$ & $<10$ \\
\hline Propylparaben & PrPB & $\mathrm{ng} / \mathrm{g}$ & $<5$ & $<5$ & $<5$ & $<5$ & $<5$ & $<5$ & $<5$ & $<5$ & $<5$ & $<5$ & $<5$ \\
\hline Aspirin & ASA & $\mathrm{ng} / \mathrm{g}$ & $<20$ & $<20$ & $<20$ & $<20$ & $<20$ & $<20$ & $<20$ & $<20$ & $<20$ & $<20$ & $<20$ \\
\hline Benzylparaben & $\mathrm{BzPB}$ & $\mathrm{ng} / \mathrm{g}$ & $<5$ & $<5$ & $<5$ & $<5$ & $<5$ & $<5$ & $<5$ & $<5$ & $<5$ & $<5$ & $<5$ \\
\hline Butylparaben & $\mathrm{BuPB}$ & $\mathrm{ng} / \mathrm{g}$ & $<5$ & $<5$ & $<5$ & $<5$ & $<5$ & $<5$ & $<5$ & $<5$ & $<5$ & $<5$ & $<5$ \\
\hline Triclocarban & TCC & $\mathrm{ng} / \mathrm{g}$ & $<1$ & $<1$ & $<1$ & $<1$ & $<1$ & $<1$ & $<1$ & $<1$ & $<1$ & $<1$ & $<1$ \\
\hline
\end{tabular}

Table D2.5 Recovery rates for each measurement.

\begin{tabular}{|c|c|c|c|c|c|c|c|c|c|c|c|}
\hline & 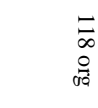 & $\begin{array}{c}\vec{\sigma} \\
\bigcirc \\
\stackrel{9}{0}\end{array}$ & $\begin{array}{l}\mathfrak{N} \\
\stackrel{+}{0} \\
\stackrel{9}{00}\end{array}$ & $\begin{array}{l}\tilde{U}_{0} \\
\infty \\
\stackrel{9}{0 a}\end{array}$ & 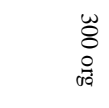 & 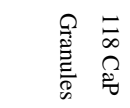 & 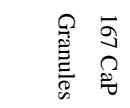 & 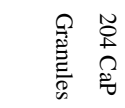 & 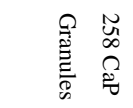 & 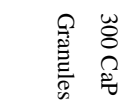 & \\
\hline PARA & $79 \%$ & $78 \%$ & $74 \%$ & $76 \%$ & $70 \%$ & $87 \%$ & $86 \%$ & $87 \%$ & $87 \%$ & $92 \%$ & $98 \%$ \\
\hline TRIM & $64 \%$ & $69 \%$ & $71 \%$ & $67 \%$ & $62 \%$ & $81 \%$ & $78 \%$ & $75 \%$ & $96 \%$ & $91 \%$ & $99 \%$ \\
\hline SUCRAL & $2 \%$ & $17 \%$ & $14 \%$ & $6 \%$ & $5 \%$ & $24 \%$ & $1 \%$ & $16 \%$ & $12 \%$ & $13 \%$ & $102 \%$ \\
\hline SULFAM & $45 \%$ & $52 \%$ & $45 \%$ & $44 \%$ & $40 \%$ & $74 \%$ & $67 \%$ & $72 \%$ & $75 \%$ & $68 \%$ & $97 \%$ \\
\hline AZI & $155 \%$ & $171 \%$ & $107 \%$ & $172 \%$ & $139 \%$ & $177 \%$ & $178 \%$ & $146 \%$ & $158 \%$ & $159 \%$ & $103 \%$ \\
\hline $\mathrm{CM}$ & $50 \%$ & $55 \%$ & $51 \%$ & $52 \%$ & $53 \%$ & $84 \%$ & $75 \%$ & $74 \%$ & $82 \%$ & $78 \%$ & $94 \%$ \\
\hline
\end{tabular}




\begin{tabular}{|c|c|c|c|c|c|c|c|c|c|c|c|}
\hline $\begin{array}{l}\text { Cont. } \\
\text { Table D2.5 }\end{array}$ & 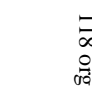 & 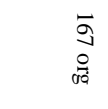 & 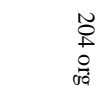 & 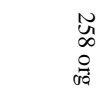 & 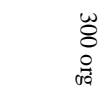 & 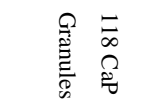 & 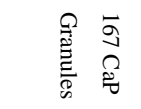 & 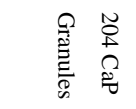 & 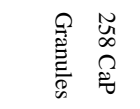 & 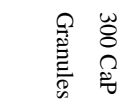 & \\
\hline SUCLOP & $27 \%$ & $29 \%$ & $24 \%$ & $16 \%$ & $21 \%$ & $47 \%$ & $32 \%$ & $37 \%$ & $41 \%$ & $42 \%$ & $104 \%$ \\
\hline SUDOX & $74 \%$ & $78 \%$ & $72 \%$ & $70 \%$ & $74 \%$ & $79 \%$ & $81 \%$ & $82 \%$ & $82 \%$ & $80 \%$ & $100 \%$ \\
\hline SMO & $35 \%$ & $35 \%$ & $34 \%$ & $33 \%$ & $31 \%$ & $55 \%$ & $40 \%$ & $51 \%$ & $51 \%$ & $41 \%$ & $88 \%$ \\
\hline TYLOS & $113 \%$ & $114 \%$ & $110 \%$ & $109 \%$ & $116 \%$ & $110 \%$ & $114 \%$ & $117 \%$ & $124 \%$ & $121 \%$ & $105 \%$ \\
\hline PENG & $79 \%$ & $84 \%$ & $84 \%$ & $84 \%$ & $88 \%$ & $82 \%$ & $96 \%$ & $94 \%$ & $108 \%$ & $85 \%$ & $106 \%$ \\
\hline CETRZ & $45 \%$ & $93 \%$ & $33 \%$ & $84 \%$ & $49 \%$ & $30 \%$ & $47 \%$ & $106 \%$ & $34 \%$ & $98 \%$ & $108 \%$ \\
\hline PENV & $102 \%$ & $88 \%$ & $104 \%$ & $83 \%$ & $77 \%$ & $79 \%$ & $81 \%$ & $80 \%$ & $96 \%$ & $82 \%$ & $111 \%$ \\
\hline CLAR & $111 \%$ & $99 \%$ & $100 \%$ & $93 \%$ & $100 \%$ & $102 \%$ & $97 \%$ & $92 \%$ & $100 \%$ & $106 \%$ & $96 \%$ \\
\hline CBZ & $77 \%$ & $84 \%$ & $79 \%$ & $83 \%$ & $82 \%$ & $91 \%$ & $86 \%$ & $88 \%$ & $87 \%$ & $78 \%$ & $95 \%$ \\
\hline KTPF & $81 \%$ & $82 \%$ & $74 \%$ & $70 \%$ & $74 \%$ & $68 \%$ & $68 \%$ & $85 \%$ & $82 \%$ & $57 \%$ & $102 \%$ \\
\hline NAPR & $61 \%$ & $59 \%$ & $51 \%$ & $47 \%$ & $47 \%$ & $38 \%$ & $35 \%$ & $58 \%$ & $51 \%$ & $26 \%$ & $94 \%$ \\
\hline IBPF & $89 \%$ & $91 \%$ & $87 \%$ & $95 \%$ & $105 \%$ & $102 \%$ & $87 \%$ & $87 \%$ & $93 \%$ & $78 \%$ & $97 \%$ \\
\hline METF & $45 \%$ & $27 \%$ & $50 \%$ & $55 \%$ & $38 \%$ & $47 \%$ & $39 \%$ & $33 \%$ & $53 \%$ & $57 \%$ & $95 \%$ \\
\hline DM & $89 \%$ & $79 \%$ & $72 \%$ & $73 \%$ & $77 \%$ & $91 \%$ & $89 \%$ & $82 \%$ & $87 \%$ & $84 \%$ & $96 \%$ \\
\hline GAPE & $90 \%$ & $88 \%$ & $81 \%$ & $91 \%$ & $80 \%$ & $90 \%$ & $95 \%$ & $89 \%$ & $84 \%$ & $90 \%$ & $95 \%$ \\
\hline SULPYR & $108 \%$ & $99 \%$ & $95 \%$ & $100 \%$ & $104 \%$ & $100 \%$ & $106 \%$ & $104 \%$ & $97 \%$ & $96 \%$ & $102 \%$ \\
\hline LINCOM & $91 \%$ & $100 \%$ & $108 \%$ & $89 \%$ & $96 \%$ & $95 \%$ & $96 \%$ & $93 \%$ & $104 \%$ & $102 \%$ & $86 \%$ \\
\hline CAF & $87 \%$ & $81 \%$ & $90 \%$ & $84 \%$ & $96 \%$ & $84 \%$ & $100 \%$ & $102 \%$ & $90 \%$ & $88 \%$ & $101 \%$ \\
\hline AMP & $47 \%$ & $44 \%$ & $42 \%$ & $41 \%$ & $52 \%$ & $66 \%$ & $53 \%$ & $53 \%$ & $54 \%$ & $54 \%$ & $94 \%$ \\
\hline OFX & $38 \%$ & $45 \%$ & $38 \%$ & $38 \%$ & $42 \%$ & $60 \%$ & $49 \%$ & $61 \%$ & $60 \%$ & $72 \%$ & $95 \%$ \\
\hline CFX & $23 \%$ & $10 \%$ & $0 \%$ & $22 \%$ & $28 \%$ & $34 \%$ & $21 \%$ & $35 \%$ & $58 \%$ & $25 \%$ & $92 \%$ \\
\hline OTETR & $49 \%$ & $48 \%$ & $37 \%$ & $40 \%$ & $40 \%$ & $67 \%$ & $52 \%$ & $55 \%$ & $62 \%$ & $60 \%$ & $78 \%$ \\
\hline
\end{tabular}


Appendices

\begin{tabular}{|c|c|c|c|c|c|c|c|c|c|c|c|}
\hline $\begin{array}{l}\text { Cont. } \\
\text { Table D2.5 }\end{array}$ & 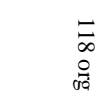 & 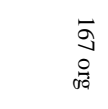 & 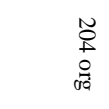 & 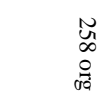 & 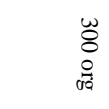 & 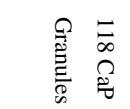 & 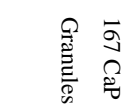 & 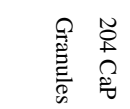 & 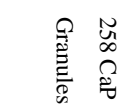 & 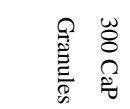 & \\
\hline CFT & $32 \%$ & $24 \%$ & $30 \%$ & $24 \%$ & $33 \%$ & $60 \%$ & $37 \%$ & $33 \%$ & $50 \%$ & $51 \%$ & $128 \%$ \\
\hline TETR & $52 \%$ & $53 \%$ & $39 \%$ & $51 \%$ & $49 \%$ & $69 \%$ & $60 \%$ & $68 \%$ & $73 \%$ & $70 \%$ & $82 \%$ \\
\hline METPL & $74 \%$ & $66 \%$ & $70 \%$ & $55 \%$ & $58 \%$ & $80 \%$ & $90 \%$ & $76 \%$ & $85 \%$ & $81 \%$ & $94 \%$ \\
\hline TILMIC & $172 \%$ & $154 \%$ & $162 \%$ & $186 \%$ & $187 \%$ & $194 \%$ & $223 \%$ & $205 \%$ & $189 \%$ & $194 \%$ & $104 \%$ \\
\hline DOX & $30 \%$ & $33 \%$ & $57 \%$ & $54 \%$ & $54 \%$ & $82 \%$ & $62 \%$ & $72 \%$ & $66 \%$ & $56 \%$ & $78 \%$ \\
\hline ERYT & $1619 \%$ & $1566 \%$ & $1608 \%$ & $1455 \%$ & $1471 \%$ & $1627 \%$ & $1913 \%$ & $2026 \%$ & $2478 \%$ & $2569 \%$ & $116 \%$ \\
\hline OXA & $75 \%$ & $74 \%$ & $71 \%$ & $64 \%$ & $71 \%$ & $80 \%$ & $74 \%$ & $83 \%$ & $89 \%$ & $69 \%$ & $97 \%$ \\
\hline FLUMEQ & $89 \%$ & $90 \%$ & $87 \%$ & $85 \%$ & $85 \%$ & $89 \%$ & $89 \%$ & $89 \%$ & $89 \%$ & $85 \%$ & $91 \%$ \\
\hline DEET & $95 \%$ & $95 \%$ & $96 \%$ & $93 \%$ & $95 \%$ & $95 \%$ & $94 \%$ & $96 \%$ & $97 \%$ & $96 \%$ & $100 \%$ \\
\hline $\mathrm{BaC} 12$ & $74 \%$ & $80 \%$ & $72 \%$ & $70 \%$ & $82 \%$ & $79 \%$ & $83 \%$ & $82 \%$ & $78 \%$ & $77 \%$ & $81 \%$ \\
\hline DFN & $93 \%$ & $89 \%$ & $87 \%$ & $80 \%$ & $84 \%$ & $85 \%$ & $79 \%$ & $89 \%$ & $90 \%$ & $70 \%$ & $95 \%$ \\
\hline $\mathrm{BaC} 14$ & $28 \%$ & $37 \%$ & $23 \%$ & $25 \%$ & $37 \%$ & $29 \%$ & $28 \%$ & $31 \%$ & $32 \%$ & $19 \%$ & $45 \%$ \\
\hline ACSUL & $63 \%$ & $127 \%$ & $120 \%$ & $186 \%$ & $119 \%$ & $117 \%$ & $107 \%$ & $114 \%$ & $110 \%$ & $107 \%$ & $102 \%$ \\
\hline НСTZ & $112 \%$ & $94 \%$ & $73 \%$ & $86 \%$ & $117 \%$ & $117 \%$ & $96 \%$ & $89 \%$ & $74 \%$ & $55 \%$ & $82 \%$ \\
\hline MCPA & $120 \%$ & $93 \%$ & $120 \%$ & $135 \%$ & $176 \%$ & $75 \%$ & $130 \%$ & $96 \%$ & $121 \%$ & $130 \%$ & $75 \%$ \\
\hline $\mathrm{MePB}$ & $195 \%$ & $166 \%$ & $161 \%$ & $182 \%$ & $178 \%$ & $184 \%$ & $176 \%$ & $184 \%$ & $200 \%$ & $159 \%$ & $107 \%$ \\
\hline МСРP & $157 \%$ & $110 \%$ & $105 \%$ & $133 \%$ & $131 \%$ & $89 \%$ & $105 \%$ & $97 \%$ & $92 \%$ & $143 \%$ & $125 \%$ \\
\hline EtPB & $115 \%$ & $152 \%$ & $148 \%$ & $147 \%$ & $155 \%$ & $166 \%$ & $124 \%$ & $114 \%$ & $110 \%$ & $131 \%$ & $93 \%$ \\
\hline PrPB & $140 \%$ & $97 \%$ & $117 \%$ & $130 \%$ & $120 \%$ & $109 \%$ & $120 \%$ & $115 \%$ & $139 \%$ & $145 \%$ & $96 \%$ \\
\hline ASA & $118 \%$ & $121 \%$ & $150 \%$ & $113 \%$ & $127 \%$ & $134 \%$ & $147 \%$ & $127 \%$ & $143 \%$ & $110 \%$ & $115 \%$ \\
\hline $\mathrm{BzPB}$ & $106 \%$ & $126 \%$ & $118 \%$ & $131 \%$ & $136 \%$ & $119 \%$ & $109 \%$ & $137 \%$ & $143 \%$ & $118 \%$ & $86 \%$ \\
\hline $\mathrm{BuPB}$ & $118 \%$ & $94 \%$ & $112 \%$ & $106 \%$ & $124 \%$ & $123 \%$ & $102 \%$ & $110 \%$ & $106 \%$ & $132 \%$ & $89 \%$ \\
\hline TCC & $71 \%$ & $74 \%$ & $71 \%$ & $74 \%$ & $68 \%$ & $87 \%$ & $84 \%$ & $87 \%$ & $82 \%$ & $68 \%$ & $77 \%$ \\
\hline TCS & $97 \%$ & $59 \%$ & $101 \%$ & $74 \%$ & $106 \%$ & $105 \%$ & $89 \%$ & $86 \%$ & $80 \%$ & $58 \%$ & $88 \%$ \\
\hline
\end{tabular}




\section{Acknowledgements}

The winter is coming!

What a good time to look back and remember everyone who somehow contributed to this book. Flashbacks which brought me to this moment, finishing a lovely book about getting the best out of sh!t. Fortunately, I have now the chance to thank you all!

First of all, I would like to thank all the management and HR of Wetsus for creating such a unique and inspiring place. The collaboration between academy and industry at Wetsus indeed stimulates the relevance of research. Regardless of the smell, I always felt the importance of my work.

I want to thank Leon for the trust and the continuous support. May sound a cliché, but, in fact, you changed my life for the better.

I am sincerely grateful to my supervisory team. Lucía, my daily supervisor, I am glad that you always gave me more than 5 minutes to help me focus and touch the earth time by time. Renata, thank you for your enthusiasm and creativity. Without you, the world of crystals would still be amorphous for me. Grietje, I am thankful for your guidance. You made the hard anaerobic digestion of organic solids easier to hydrolyze for me. Cees, your realistic and pertinent vision was fundamental to direct my work and to give the best of myself. I wonder if I was a controller before your supervision!

Taina, thank you for the heritage and hints. I want to thank all the participants from Source Separated Sanitation theme for the innumerous fruitful discussions and suggestions. Particularly, I am thankful to Brendo and Nico for the support and the black water from Lemmerweg. A special thank you to Hardy for the scientific support. Also, I want to thank Wageningen University and University Campus Friesland for the knowledge and guidance.

I want to thank Prof. Eugénio Ferreira and Daniela Mesquita for the inspiration and lessons which were extremely important during my $\mathrm{PhD}$.

I want to thank the fantastic Technical Team of Wetsus. In particular, Mieke, Marianne, Jelmer, and Aga thank you for the patience and support. Ernst and Jan, you help me a lot with my set-up, but also pushed me to do it myself. I learned a lot with that! 
Appendices

To my students, Tanya, Biense, Joana the $1^{\text {st }}$, Mara, Carolin, BSc Chris, Joana the $2^{\text {nd }}$, MB, Jerre, Sara, Joana the $3^{\text {rd }}$, Martin, MSc Chris, Mahesa, Laura, and PhD Chris I am immensely grateful for your contribution, enthusiasm, and care.

My dear officemates, Maarten, Karine, Stan, Nimmy, Steffen, Paulina, Maurits, Pom, Vytautas, and Martijn, thank you for the companionship and every day laughs! A special thank you to my oldest officemates and my paranymphs, BDRik and Jacob Paulus. Ricky boy even after having me every day in front of you, you still choose a Portuguese for you! Jaap, besides officemate, you were also my deskmate, housemate, teammate, and somewhat confidante as well. I made you bald my friend!

I want to thank all my colleagues at Wetsus for the shared amazing experiences, cooperation, and joy. A monstrous thank you to the lovely band members, Gonçalo, Stan, Fabian, Jorrit, Louis, Prashant, Sofia, Victor T., Pau, Brahzil, Michele, Steffen, Carlone, and Mariagiorgia. We made music with science! Also, I want to thank the futsal teammates and the volleyball stars for the sweat and passion.

A special thank you to Philipp, Prashant, Thomas, and Yang for sharing the same goal, phosphorus recovery. A big thank you to Jordi for the ride on my very first arrival in Leeuwarden. João thank you for the talks on our way to Zwolle. Casper and Victor A., it was a pleasure to organize practical lectures with you. Hector thank you for the way you look at me. Terica, it was a pleasure to join Wetsus with you. Thank you Rebeca for being with me in the $\mathrm{PhD}$ representatives.

I want to thank my football teammates from L.A.C. FRISIA 1883 for making my life in Friesland less cold, for teaching a bit of Dutch, and for showing me the province with away games. In particular, a big thank you to Arjan, Peter, Joost, Leon, Cor, Folkert, Jordi, Mitchel, Rono, and Johannes.

Pedro and Cristina, my friends from the university time, thank you for sharing your household in Leeuwarden. I truly felt and still feel part of the family, just like Eva!

Quero agradecer à minha família por toda a ajuda e carinho mesmo estando a muitos quilómetros de distancia. Em especial quero agradecer à Maria Elisabete pela sugestão em estudar ciências ambientais para proteger o planeta. Agradeço à minha Avó Rosa por me motivar a estudar para ter uma trabalho limpinho. Este livro é o fruto dessa sugestão e motivação. Agradeço também a todos os meus amigos que de uma forma ou outra contribuíram para esta obra. Quero destacar o Carlos e o Bruno, pela paciência e conselhos para a vida. Ich will der neuen Familie und den Freunden in Düsseldorf danken und auch dafür, das seine aufregende Zukunft bevorsteht. 
Estou eternamente grato aos meus pais, Jorge e Júlia, pelo afeto, paciência e educação. Vós sempre suportastes todas as minhas decisões e destes-me motivação para seguir o meu instinto que me levou a esta graduação. Com o mesmo sentimento, agradeço também ao meu irmão, Eduardo. Obrigado por tudo!

Ein besonderes Dankeschön reicht nicht aus für Dich! Von allen warst du die jene, die mich jeden Tag unterstützt und mir die Kraft gibt, die Schwierigkeiten zu überwinden die ein Doktortitel mit sich bringen kann. Ich bin dir wirklich sehr dankbar, Lina Bachert da Cunha. Ich bin stolz, dass wir den Nachnamen teilen können und was damit das Einhergehende. Ich liebe dich. 


\section{About the author}

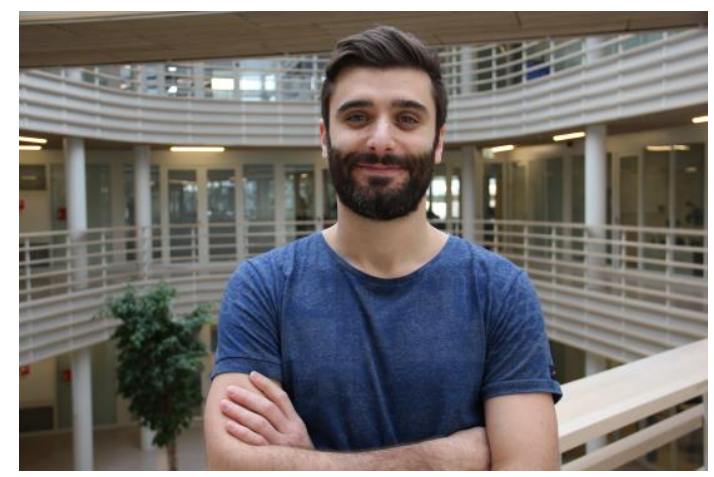

Jorge Ricardo Apolinário Macedo Bachert da Cunha was born on 14th of September in 1987 in Carreiras São Miguel, a small village in the district of Braga in Portugal. In 2005, he started his Integrated Master's program in Biological Engineering at the Department of Biological Engineering at the University of Minho in Braga. His Master thesis was on the subject "Evaluation of an Activated Sludge System by Image Analysis and Chemometric Techniques". After his Master's graduation in 2010, he worked as a researcher fellow studying the operation of bioreactors for simultaneous production of polyhydroxyalkanoates (PHAs) and removal of phosphorus at the Centre of Biological Engineering (University of Minho). In 2013, he did a feasibility study on polyphosphate recovery from sewage sludge at Wetsus, European Centre of Excellence for Sustainable Water Technology, in Leeuwarden (the Netherlands). Afterward, he started his work as a PhD student of the Sub-department of Environmental Technology (ETE) at Wageningen University, but was stationed at Wetsus in Leeuwarden. Since June 2017, he is a pre post-doc at Wetsus working on calcium phosphate recovery from animal manure. 


\section{SENSE}

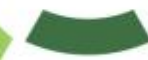

Netherlands Research School for the

Socio-Economic and Natural Sciences of the Environment

\section{I P L O M A}

For specialised PhD training

The Netherlands Research School for the Socio-Economic and Natural Sciences of the Environment (SENSE) declares that

\section{Jorge Ricardo Cunha}

born on 14 September 1987 in Carreiras São Miguel, Portugal

has successfully fulfilled all requirements of the Educational Programme of SENSE.

Leeuwarden, 30 November 2018

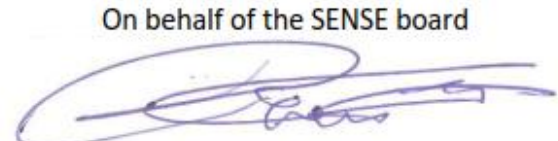

Prof. dr. Huub Rijnaarts

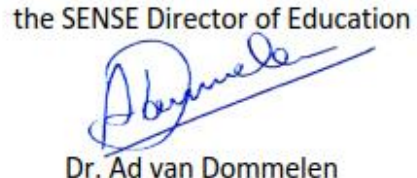

Dr. Ad van Dommelen

The SENSE Research School has been accredited by the Royal Netherlands Academy of Arts and Sciences (KNAW) 


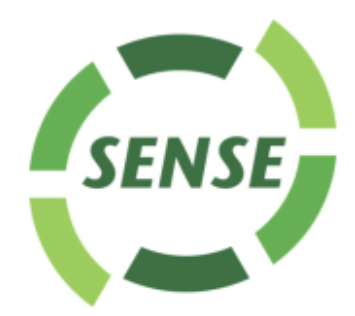

The SENSE Research School declares that Jorge Ricardo Cunha has successfully fulfilled all requirements of the Educational PhD Programme of SENSE with a work load of $38.5 \mathrm{EC}$, including the following activities:

\section{SENSE PhD Courses}

- Environmental research in context (2014)

- Research in context activity: 'Co-organizing session on Biomineralization as part of the Wetsus Symposium on Financing Innovations (Leeuwarden, 3-4 October 2016)

- SENSE writing week (2016)

\section{Selection of other PhD and Advanced MSc Courses}

- Supervision of students by PhD researchers, Wetsus (2014)

- The 1st European School on Crystal Growth, Bologna, Italy (2015)

- Laser worker training, Wetsus (2015)

- The essentials of scientific writing \& presenting, Wageningen in'to Languages, the Netherlands (2015)

- Image processing for scientists: Adobe Illustrator \& Design, Wetsus (2016)

- Introduction course on pattern fitting for TOPAS, Bruker, Leiden, the Netherlands (2017)

- Communication Styles, How Company, the Netherlands (2017)

\section{Selection of Management and Didactic Skills Training}

- PhD Representative, Wetsus, (2015-2018)

- Supervising eight MSc students with thesis (2015-2018)

- Supervising two BSc student with thesis (2016-2017)

- Lecturing and assisting in MSc course 'Biological Wastewater Treatment' (2015-2017)

- Business Development Course, Klimate-Kic, the Netherlands (2017)

\section{Oral Presentations}

- New approaches to phosphate recovery. Environmental Technology for Impact: 50 years Environmental technology (ETEI2015), 28-29 April 2015, Wageningen, the Netherlands

- Combined calcium phosphate recovery and methane production from black water treatment using a UASB reactor. BENELUX Young professionals 4th Regional Conference, 28 September 2015, Leeuwarden, the Netherlands

- Simultaneous calcium phosphate granules and methane recovery from black water. 13th IWA on small water and wastewater systems and 5th IWA on resources-oriented sanitation, 14-17 September 2016, Athens, Greece

- Recovery of Calcium Phosphate and Methane from black water using a UASB reactor. The 2nd International Resource Recovery Conference, 5-9 August 2017, New York, USA

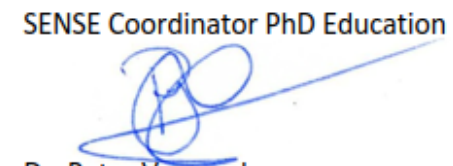

Dr. Peter Vermeulen 
This work was performed within the cooperation framework of Wetsus, European Centre of Excellence for Sustainable Water Technology (www.wetsus.eu). Wetsus is cofunded by the Netherlands' Ministry of Economic Affairs and Climate Policy and Ministry of Infrastructure and Water Management, the European Union's Regional Development Fund, the Province of Fryslân, and the Northern Netherlands Provinces. The authors thank the participants of the research theme "Source Separated Sanitation" for the fruitful discussions and financial support.

Cover design: Jorge Ricardo Cunha

Front cover photo: Jorge Ricardo Cunha

Back cover photo: Joana Neiva

Printed by: Digiforce || ProefschriftMaken 